\title{
DANIEL PERDIGÃO-NASS
}

\section{Licenciaturas a distância em Física e Química \\ no Tocantins: trajetórias, possibilidades e limites}

Tese apresentada ao Programa Interunidades em Ensino de Ciências, da Universidade de São Paulo, obrigatória para a obtenção do título de Doutor em Ciências.

Área de concentração: Ensino de Física

Orientador: Prof. Dr. Luís Carlos de Menezes

São Paulo 
Autorizo a reprodução e a divulgação total ou parcial deste trabalho, por qualquer meio convencional ou eletrônico, somente para fins de estudo e pesquisa e sem fins lucrativos, desde que citados autor e fonte.

Este exemplar foi revisado e alterado em relação à versão original, sob a exclusiva responsabilidade do autor.

São Paulo, 29 de novembro de 2012.

Daniel Perdigão-Nass

Ficha catalográfica preparada pelo Serviço de Biblioteca e Informação do Instituto de Física da Universidade de São Paulo

Perdigão-Nass, Daniel

Licenciaturas a distância em Física e Química no Tocantins: trajetórias, possibilidades e limites. São Paulo, 2012.

Tese (Doutorado) - Universidade de São Paulo. Faculdade de Educação, Instituto de Física, Instituto de Química, Instituto de Biociências.

Orientador: Prof. Dr. Luís Carlos de Menezes

Área de Concentração: Ensino de Física

Unitermos: 1. Formação de professores; 2. Educação a distância; 3. Ensino de Ciências.

USP/IF/SBI-070/2012 
PERDIGÃO-NASS, Daniel. Licenciaturas a distância em Física e Química no Tocantins: trajetórias, possibilidades e limites. 2012. 180 f. Tese (Doutorado em Ensino de Ciências). Programa Interunidades em Ensino de Ciências, Universidade de São Paulo, São Paulo, 2012.

Aprovada em 14 de novembro de 2012.

\section{Banca examinadora}

Prof. Dr. Luís Carlos de Menezes - orientador

Universidade de São Paulo

Prof. Dr. Fernando José de Almeida

Pontifícia Universidade Católica de São Paulo

Prof. Dr. José André Peres Angotti

Universidade Federal de Santa Catarina

Profa. Dra. Marta Maria Castanho Almeida Pernambuco

Universidade Federal do Rio Grande do Norte

Prof. Dr. Sérgio Henrique Bezerra de Sousa Leal

Universidade Federal do ABC 
Aos bons amigos 


\section{AGRADECIMENTOS}

Inicialmente, agradeço ao meu orientador, Luís Carlos de Menezes, pela oportunidade de aprender tanto, sobre tantas coisas diferentes, em tão pouco tempo, e pela confiança depositada em diversos momentos deste curso de doutoramento. Não posso deixar de reconhecer a ajuda da professora Yassuko Hosoume, que me recomendou ao professor Menezes.

Agradeço, também, a todas as pessoas que contribuíram para a realização deste trabalho. Incluo aqui: professores, tutores, gestores e colaboradores da educação a distância da Universidade Federal do Rio Grande do Norte, Universidade Federal do Piauí e Universidade Federal do Tocantins, pela colaboração direta ou indireta com a pesquisa; meus empregadores no período, Ministério da Educação e Universidade Federal do Tocantins, por sempre autorizar minhas viagens referentes a esta pesquisa; o pessoal da Capes, que possibilitou, com diárias e passagens, a viagem ao Piauí; os orientadores acadêmicos da Secretaria de Educação a Distância do Ministério da Educação, os professores das disciplinas cursadas na Universidade de São Paulo e os membros das bancas de qualificação e de defesa, pela troca de experiências e pelas observações e orientações. O apoio de funcionários e alunos das instituições citadas também merece meu reconhecimento e minha gratidão.

Um agradecimento especial faço a Michelle Zampieri, companheira de quase duas décadas, pelo apoio, pelas críticas, pela leitura cuidadosa dos escritos, pelos questionamentos e, até mesmo, por esse amor correspondido nestes tempos turbulentos. 
"A boniteza de ser gente se acha, entre outras coisas, nessa possibilidade e nesse dever de brigar" Paulo Freire 


\section{RESUMO}

\section{PERDIGÃO-NASS, Daniel. Licenciaturas a distância em Física e Química no Tocantins:}

trajetórias, possibilidades e limites. 2012. 180 f. Tese (Doutorado em Ensino de Ciências). Programa Interunidades em Ensino de Ciências, Universidade de São Paulo, São Paulo, 2012.

A educação a distância (EaD) tem recebido crescente atenção da comunidade educativa e verbas mais expressivas dos poderes públicos. Em particular, políticas públicas nacionais têm direcionado a educação superior a distância também para a formação inicial e continuada dos professores. Esta pesquisa buscou analisar criticamente aspectos de concepção, elaboração, planejamento, organização, implantação e andamento dos cursos de licenciatura em Física e em Química, na modalidade EaD, no âmbito da Universidade Federal do Tocantins. Iniciou-se e ambientou-se a pesquisa com uma apreciação da problemática da $\mathrm{EaD}$ e de aspectos relacionados à formação docente, assim como com um histórico de sua implementação no Brasil. A análise específica foi conduzida de forma comparativa com o processo levado a cabo nos cursos homólogos da Universidade Federal do Rio Grande do Norte, cujos planos pedagógicos e materiais didáticos serviram de modelo na elaboração dos documentos equivalentes dos cursos tocantinenses. A investigação empírica adotou procedimentos de pesquisa-participante e de estudo de caso, analisou fontes documentais e materiais didáticos, realizou entrevistas com professores e dirigentes, assim como discutiu questionários aplicados aos estudantes. Com esses meios, revelaram-se aspectos que permitiram comparar a eficácia pretendida com a alcançada e identificar potencialidades e limitações da formação inicial a distância de professores no Brasil. As conclusões desta pesquisa podem orientar políticas públicas de oferta de educação a distância que visem a mitigar a carência de professores nas áreas científicas ao apontar a necessidade de dar estabilidade a programas como o Sistema Universidade Aberta do Brasil. Para isto, é indispensável garantir recursos humanos e materiais, obter sinergia entre níveis de governo e universidades e assegurar sintonia entre o projeto pedagógico e o professor que se busca formar.

Palavras-chave: educação a distância, formação de professores, ensino de ciências 


\begin{abstract}
PERDIGÃO-NASS, Daniel. Teacher education by distance in Physics and Chemistry in Tocantins, Brazil: pathways, possibilities and limits. 2012. 180 p. Thesis (Doctorate in Science Teaching). Programa Interunidades em Ensino de Ciências, Universidade de São Paulo, São Paulo, 2012.
\end{abstract}

Distance education has received increasing attention from the educational community, more significant public funding. National public policies seem to embrace tertiary distance education also for the initial teacher training and continuing and professional development. This research sought to critically analyze aspects of design, development, planning, organization, deployment and working of undergraduate distance learning courses in physics and chemistry at the Federal University of Tocantins. This research started up with a broad assessment of the problem of distance education and issues related to teacher training, as well as a history of its implementation in Brazil. A specific analysis was managed in a comparative way with the process conducted in counterpart courses at the Federal University of Rio Grande do Norte, whose pedagogical plans and teaching resources served as a model to the equivalent documents of the courses of Tocantins. The empirical investigation adopted participatory research and case study procedures, analyzed official documents and teaching resources, conducted interviews with teachers and leaders, and discussed surveys applied to students. With these methods, this research aimed to show aspects that allow comparing the desired effectiveness with the achieved ones, besides identifying possibilities and limitations of the distance training of teachers in Brazil. The conclusions of this research can be helpful to guide distance education public policies to mitigate the lack of teachers for the scientific areas, by pointing out the need of institutional stability to programs like the Universidade Aberta do Brasil (Open University of Brazil). In order to achieve this, it is essential to assure human and material resources, to reach synergy between government levels and universities, and to ensure convergence between pedagogical project and the teacher wanted to be formed.

Keywords: distance education, teacher education, science education 


\section{LISTA DE FIGURAS}

Figura 1 - Mapa dos estados do Rio Grande do Norte, Paraíba, Pernambuco e Alagoas com a identificação dos municípios que possuem polos

Figura 2 - Mapa do estado do Tocantins com a identificação dos municípios que possuem polos $\mathrm{UAB}$ 


\section{LISTA DE TABELAS}

Tabela 1 - Caracterização dos municípios com vagas para os cursos de Física e de Química da UFRN

Tabela 2 - Caracterização dos municípios com vagas para o curso de Física UFT

Tabela 3 - Caracterização dos municípios com vagas para o curso de Química UFT

Tabela 4 - Cursos e polos dos respondentes da pesquisa

Tabela 5 - Respostas ao item "Antes de ingressar neste curso, ficou quanto tempo sem estudar regularmente?"

Tabela 6 - Respostas ao item “A opção pela modalidade a distância foi feita por quê?” 108

Tabela 7 - Respostas ao item "O que o levou a fazer este curso?" 109

Tabela 8 - Respostas ao item "Você atua como professor?"

Tabela 9 - Respostas ao item "Se já atuou como professor, indique os níveis e modalidades de ensino."

Tabela 10 - Respostas ao item "Você já havia tido algum tipo de contato com a educação a distância, seja como aluno, tutor ou professor, antes de iniciar este curso?"

Tabela 11 - Respostas ao item "Distância aproximada de sua residência ao seu polo"

Tabela 12 - Respostas ao item “O que você pretende fazer após a conclusão do curso?” 112

Tabela 13 - Respostas ao item "Quanto tempo você dedica aos estudos semanalmente?" 112

Tabela 14 - Respostas ao item "Qual a sua idade?” 113

Tabela 15 - Respostas ao item "Qual o seu estado civil?" 113

Tabela 16 - Respostas ao item "Informações sobre mobilidade e interação informática." 114

Tabela 17 - Respostas obtidas para o item "Indique o aspecto peculiar da educação a distância baseada em tecnologias da informação e comunicação que, para você, teve o menor grau de dificuldade (a tarefa mais fácil)"

Tabela 18 - Respostas obtidas para o item "Indique o aspecto peculiar da educação a distância baseada em tecnologias da informação e comunicação que, para você, teve o maior grau de dificuldade (a tarefa mais difícil)"

Tabela 19 - Número de alunos que frequentou regularmente o polo em abril de $2012 \quad 116$

Tabela 20 - Perfil de titulação dos docentes dos cursos pesquisados na UFRN e na UFT 129

Tabela 21 - Perfil de graduação dos docentes dos cursos pesquisados na UFRN e na UFT 129 


\section{LISTA DE SIGLAS}

AACC Atividades acadêmico-científico-culturais

Anfope Associação Nacional pela Formação dos Profissionais da Educação

Capes Coordenação de Aperfeiçoamento de Pessoal de Nível Superior

CD Compact Disc ou Conselho Deliberativo

Cecierj Centro de Ciências de Educação Superior a Distância do Rio de Janeiro

Cederj Consórcio de Educação Superior a Distância do Estado do Rio de Janeiro

CNTE Centro de Novas Tecnologias Educacionais

CTE Centro de Tecnologias Educacionais

DTE Diretoria de Tecnologias Educacionais

DVD Digital Video Disc

EaD Educação a Distância

Eadcon Sociedade Civil de Educação Continuada Ltda.

FNDE $\quad$ Fundo Nacional para o Desenvolvimento da Educação

Fundeb Fundo de Manutenção e Desenvolvimento da Educação Básica e Valorização dos Profissionais da Educação

IBGE Instituto Brasileiro de Geografia e Estatística

IES Instituição(ões) de Ensino Superior

Inep Instituto Nacional de Estudos Pedagógicos Anísio Teixeira

LDB Lei de Diretrizes e Bases da Educação Nacional

MEC Ministério da Educação

Moodle Modular Object-Oriented Dynamic Learning Environment

NDE Núcleo Docente Estruturante

OA Orientador(es) Acadêmico(s)

Parfor Programa de Ações Articuladas do Plano Nacional de Formação de Professores da Educação Básica

Pibid Programa Institucional de Bolsas de Iniciação à Docência

PNE Plano Nacional de Educação

PPC Projeto Pedagógico do Curso

Proformação Programa de Formação de Professores Leigos em Exercício

Saeb Sistema de Avaliação da Educação Básica

SEB Secretaria de Educação Básica (MEC)

Sedis Secretaria de Educação a Distância (UFRN) 
Seed Secretaria de Educação a Distância (MEC)

$\mathrm{SESu} \quad$ Secretaria de Educação Superior

TIC Tecnologias de informação e de comunicação

UAB Sistema Universidade Aberta do Brasil

UEPB Universidade Estadual da Paraíba

Ufal Universidade Federal de Alagoas

UFMT Universidade Federal de Mato Grosso

UFPI Universidade Federal do Piauí

UFRN Universidade Federal do Rio Grande do Norte

UFSC Universidade Federal de Santa Catarina

UFSM Universidade Federal de Santa Maria

UFT Universidade Federal do Tocantins

UnB Universidade de Brasília

Undime União Nacional dos Dirigentes Municipais de Educação

Unesco Organização das Nações Unidas para a Educação, a Ciência e a Cultura

UniRede Universidade Virtual Pública do Brasil

Unitins $\quad$ Fundação Universidade do Tocantins

UPE Universidade de Pernambuco

USP Universidade de São Paulo 


\section{SUMÁRIO}

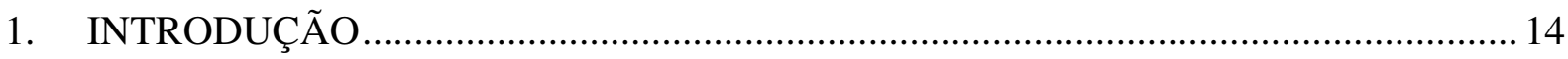

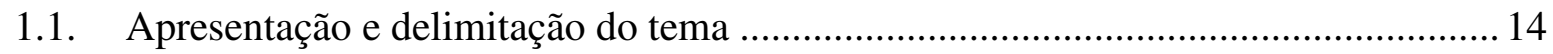

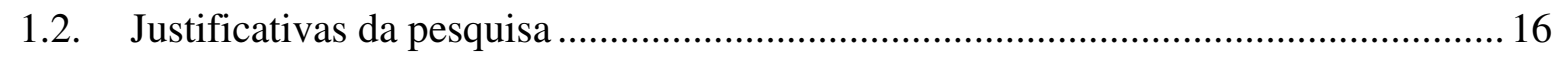

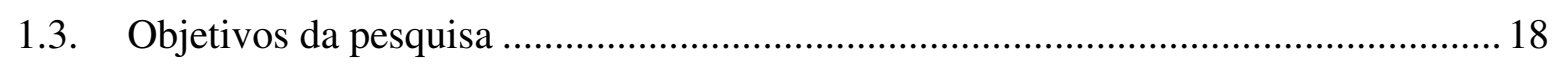

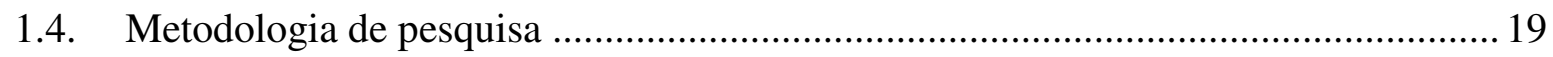

2. EDUCAÇÃO A DISTÂNCIA: RECURSOS E CONTEXTOS ....................................22

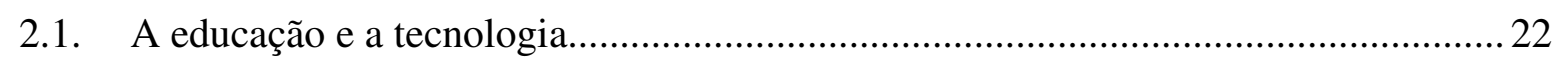

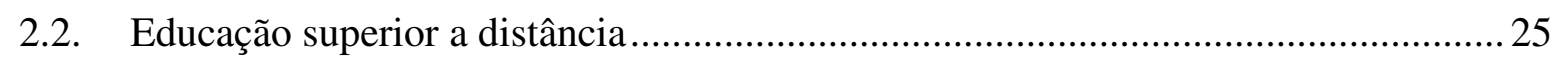

2.3. EaD de nível superior no Brasil: gestão, regulamentação e política..........................29

3. FORMAÇÃO DE PROFESSORES A DISTÂNCIA..................................................... 34

3.1. Formação de professores a distância no mundo .................................................... 34

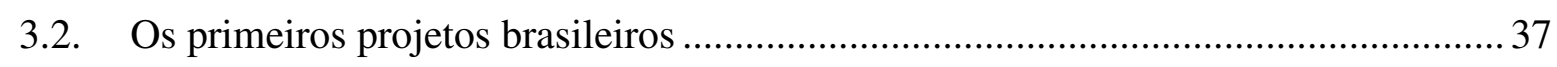

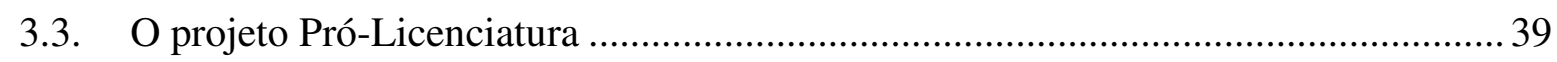

3.4. Sistema Universidade Aberta do Brasil .................................................................. 41

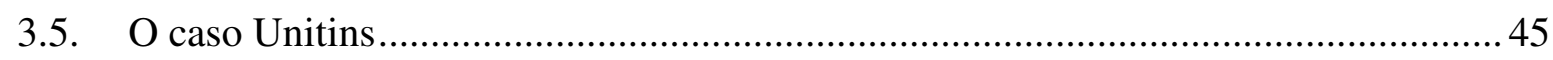

3.6. Posicionamentos quanto à formação de professores a distância.............................. 49

3.7. Formaçãa de professores de ciências a distância .........................................................56

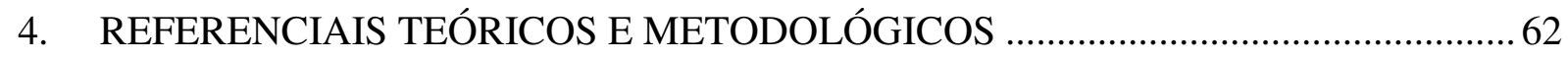

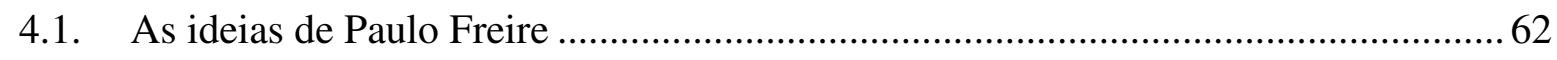

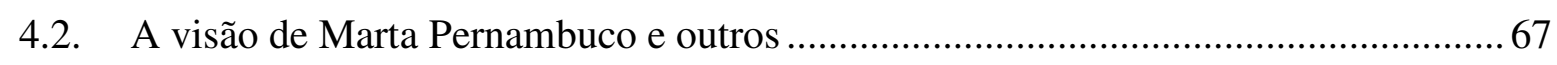

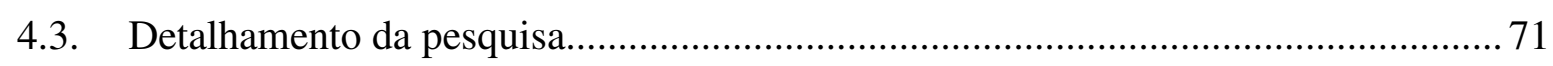

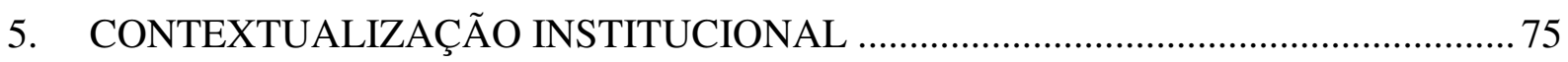

5.1. Os estados do Rio Grande do Norte e do Tocantins .................................................. 75

5.2. Educação nos estados do Rio Grande do Norte e do Tocantins ................................ 77

5.3. As universidades federais do Rio Grande do Norte e do Tocantins ......................... 79

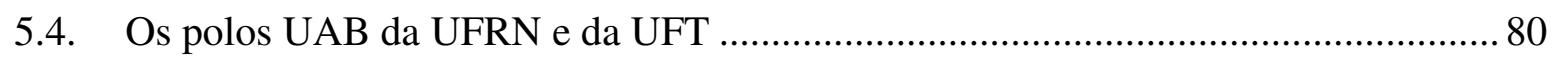

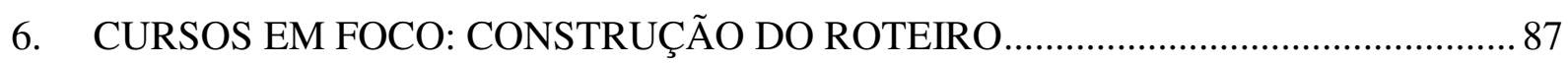

6.1. O processo de criação institucional da $\mathrm{EaD}$ e dos cursos ......................................... 87

6.2. A elaboração dos projetos pedagógicos ................................................................. 90

6.3. Organização curricular e conteúdos programáticos ............................................... 99 
7. CURSOS EM FOCO: CARACTERIZAÇÃO DOS PERSONAGENS.

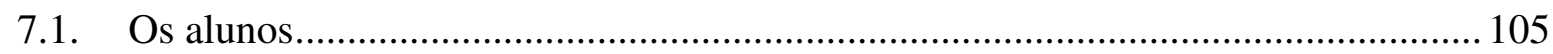

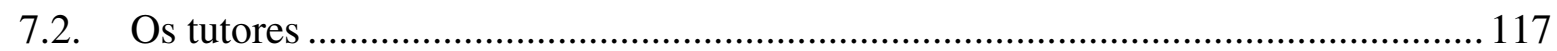

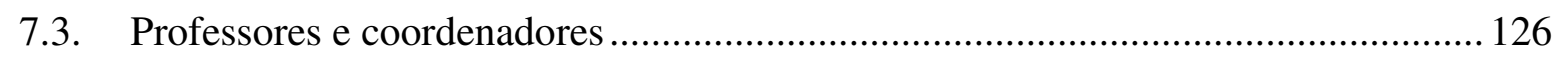

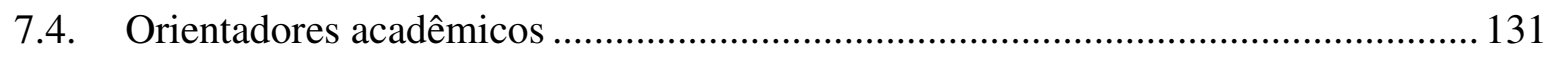

8. CURSOS EM FOCO: CENÁRIOS, FIGURINOS E A AÇÃO......................................... 134

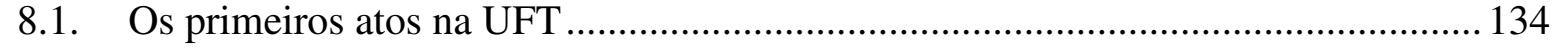

8.2. Os materiais didáticos e os conteúdos curriculares................................................. 137

8.3. O ambiente virtual de ensino-aprendizagem …………........................................ 145

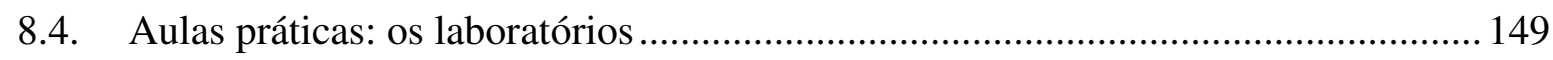

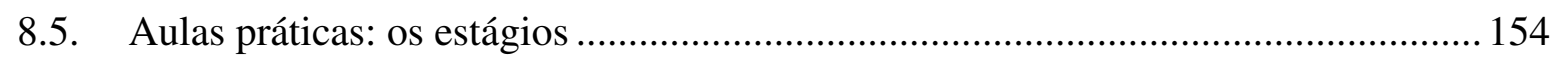

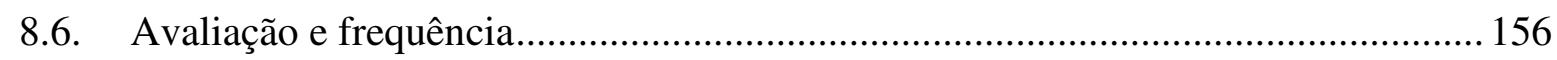

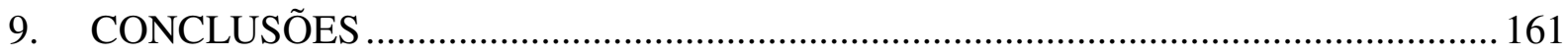

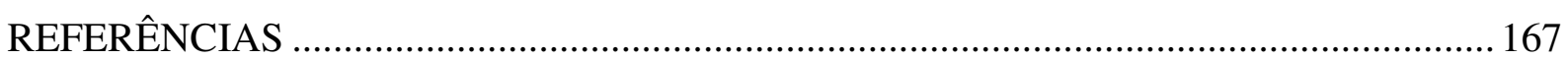




\section{INTRODUÇÃO}

\subsection{Apresentação e delimitação do tema}

Esta tese apresenta uma investigação de dois cursos de formação inicial de professores, um curso de Licenciatura em Física e outro em Química, na modalidade ${ }^{1}$ a distância, mantidos pela Universidade Federal do Tocantins (UFT). O que se pretende analisar criticamente, com o rigor de uma pesquisa qualitativa em educação, são aspectos de concepção, elaboração, planejamento, organização, implantação e operação desses cursos. Eles foram originalmente concebidos pela Universidade Federal do Rio Grande do Norte (UFRN) e seus projetos pedagógicos e materiais didáticos foram utilizados pelos cursos homólogos da UFT.

O Tocantins sediou a primeira das instituições públicas brasileiras de ensino superior a oferecer vasta gama de graduações na modalidade de educação a distância (EaD): a Fundação Universidade do Tocantins (Unitins), estadual. A Unitins não limitou esta oferta ao Tocantins, mas esteve presente em todos os estados brasileiros. Os cursos da UFT aqui estudados tiveram a participação de diversos professores e profissionais supostamente experientes nesta modalidade, por já terem feito parte do quadro docente da EaD da Unitins. No entanto, no que toca à Unitins, os cursos em questão tiveram suas matrículas encerradas pelo Ministério da Educação (MEC), por razões que discutirei posteriormente.

Os cursos da UFRN estão entre os primeiros cursos de licenciatura em Ciências em EaD criados no país. De acordo com a professora Marta Pernambuco, da UFRN, o curso de Física foi o terceiro a ser implantado no Brasil, enquanto o curso de Química foi o primeiro. Até hoje, a UFRN destaca-se nacionalmente no campo da $\mathrm{EaD}$, sendo, por exemplo, uma das poucas instituições do país a realizar a revisão de estrutura e linguagem de materiais didáticos criados para a $\mathrm{EaD}$ superior, a única da região Norte-Nordeste.

Os cursos da UFRN e da UFT possuem, em seus planos pedagógicos, diretrizes metodológicas baseadas no trabalho de Paulo Freire; em especial, os planos remetem a conceitos como abordagem problematizadora e tema gerador. A influência vem da então coordenadora pedagógica da EaD no âmbito da UFRN, a professora Marta Maria Castanho

\footnotetext{
${ }^{1}$ Embora, como frequentemente ocorre na literatura especializada, a educação a distância seja tida como uma modalidade de ensino, há autores, destacados por Alonso (2010), que a veem como uma metodologia de ensino, ou como uma estratégia de ensino.
} 
Almeida Pernambuco, que possui significativa produção bibliográfica referenciada por estes conceitos, a qual utilizei parcialmente para referenciar este trabalho. As duas instituições também têm em comum o fato de os cursos examinados estarem entre as primeiras graduações na modalidade de $\mathrm{EaD}$ nas respectivas instituições. Assim, ainda que alguns dos professores envolvidos nos cursos examinados tivessem experiências anteriores na modalidade de $\mathrm{EaD}$, as instituições onde os cursos foram implantados não possuíam experiência em EaD.

Diferencia os cursos das duas instituições o perfil de formação dos líderes do processo de implantação dos cursos. Além disso, uma vez que os cursos da UFRN já têm turmas formadas, enquanto os cursos da UFT foram iniciados em fins de 2010, certas observações somente puderam ser feitas nos cursos potiguares. Outra particularidade dos cursos do Tocantins é a existência da figura dos orientadores acadêmicos (OA). Trata-se de profissionais contratados temporariamente em 2009 pelo MEC, com formação mínima de mestrado na área da respectiva ciência e/ou em ensino de ciências, para atuar no apoio à EaD junto aos polos de apoio presencial e às coordenações dos cursos. Eu, autor deste trabalho, fui, por 16 meses, um destes OA. Mais especificamente, atuei junto à coordenação do curso de Química da UFT. Posteriormente, já como docente da mesma universidade, atuei como tutor e docente do curso, além de manter parte das atividades e atribuições que possuía quando ocupava o cargo no MEC.

Assim, se a busca intensa e completa por elementos dos cursos da UFRN e da UFT configura um estudo de casos, não podemos ignorar que a participação deste autor na estruturação e implantação dos cursos da UFT possui elementos característicos da pesquisa participante. A análise dos cursos potiguares serviu, predominantemente, para se obter informações e conhecimentos que pudessem ser aplicados nos cursos da UFT.

Uma vez que existem elementos que fazem desta uma pesquisa participante, cabe fazer um rápido resumo da minha trajetória acadêmica antes e durante a execução deste trabalho. Ao longo de minha graduação como bacharel em Química, entre 2000 e 2003, realizei trabalhos na área do ensino de Ciências, como editar por 16 meses uma revista eletrônica de divulgação científica e atuar por outros 12 meses como tutor plantonista no serviço Dúvidas de Química (Duquim), sendo ambos os serviços oferecidos via internet pela página do Centro de Divulgação Científica e Cultural (CDCC) da Universidade de São Paulo (USP). Em 2005, iniciei dois cursos: uma licenciatura em Ciências Exatas, obtendo habilitações em Física e em Química em 2009; e também um mestrado na área de Ensino de Química, concluído em 2008, sendo todos os cursos realizados na USP. Neste período, ofereci um curso pré-vestibular em 
Matemática, Física e Química, cujo material didático veio a se transformar, em 2009, em três livros publicados. Após o ingresso no quadro da Secretaria de Educação a Distância (Seed) do MEC, ocorrido em outubro de 2009, meses depois do meu ingresso neste doutorado em Ensino de Física, passei a fazer outros cursos na modalidade a distância: uma graduação em Pedagogia, cursada em uma universidade privada paulista, e uma especialização em Gestão Educacional, oferecida por uma universidade federal gaúcha, ambos os cursos iniciados em fevereiro de 2010, e um mestrado profissionalizante em Matemática, iniciado em março de 2012. Estas experiências como discente de cursos na modalidade a distância certamente também influenciaram o presente trabalho, e é sob este prisma, da posição de quem, além de elaborador, professor e tutor, é aluno de $\mathrm{EaD}$, que certas conclusões puderam ser obtidas. A seguir, busco justificar por que esta pesquisa merece ser considerada pertinente do ponto de vista da pesquisa em educação e em ensino de ciências.

\subsection{Justificativas da pesquisa}

O professor, devido ao seu papel prático na formação discente, é parte fundamental em qualquer processo de manutenção ou de reforma do sistema educacional, pois é ele o responsável por implantar ou não as sugestões de mudanças nas políticas educacionais, nos currículos ou nas tendências pedagógicas. Eis a razão principal pela qual uma das principais vertentes da pesquisa em educação é o estudo da formação dos professores (SILVA, 2008; CASTRO; CARNOY, 1997). Uma das teorias educacionais mais frequentemente presentes na área na atualidade discute esta temática sob a ótica da epistemologia da prática, ou seja, com a ideia de que os professores são formados a partir de aspectos pessoais, profissionais e institucionais, sem fronteiras claras entre tais aspectos. Além disso, também defende que a boa prática docente deve estar avalizada por um bom conhecimento das teorias, práticas e práxis educacionais, dos conteúdos ministrados, dos currículos, e daquilo que se convencionou chamar conhecimento pedagógico do conteúdo, com sistemática e central reflexão sobre a prática (SHULMAN, 1986; SILVA, 2008). Neste contexto, ser professor é uma ação constituída e aprimorada na prática, enquanto o profissional reflete a partir da observação e da ação de situações reais.

Paralelamente, no Brasil, em todos os níveis de governo e, também, na iniciativa privada, observa-se um investimento crescente em $\mathrm{EaD}$ de nível superior. Os programas de EaD estão na pauta da agenda governamental, pois órgãos como o Banco Mundial 
recomendam a EaD, por sua boa relação eficiência versus custos (SCAFF, 2000), especialmente quando considerada a aplicação de cursos em larga escala. Além de programas como o Sistema Universidade Aberta do Brasil (UAB), federal, e a associação entre a Unitins e a empresa Sociedade Civil de Educação Continuada Ltda. (Eadcon), observam-se diversas outras iniciativas. Novos cursos são criados, com formatos convencionais ou inovadores. Desde o início da década passada, a legislação da área vem sendo intensamente revista e ampliada. Congressos, livros, artigos, enfim, a produção intelectual sobre o assunto é cada vez maior.

Entende-se que a integração destas duas áreas, ou seja, a formação de professores e a modalidade $\mathrm{EaD}$, abriu um novo campo para a pesquisa em educação. Especialmente se considerarmos que todas as iniciativas em EaD citadas até aqui incluem, parcial ou totalmente, a formação de professores, com centenas de milhares de aprendizes apenas no Brasil. Mas, mesmo com a nítida consolidação da modalidade, ainda persistem dúvidas e preconceitos. De fato, a discussão da EaD como uma política pública de inclusão e de desenvolvimento social e econômico envolve interesses diversos. As críticas que a modalidade EaD recebe, hoje, de muitos especialistas em educação são pesadas e, no mínimo, merecem ser discutidas e examinadas.

Freire (2009) e Schneider (2008) consideram que a formação do professor é fundamental, podendo proporcionar uma educação libertadora, problematizadora, ou se limitar a uma educação bancária, massificada, que talvez não atenda às particularidades e às idiossincrasias. Para saber como a EaD opera na formação de professores, assumirei o pressuposto de que novas tecnologias de informação e de comunicação (TIC) abrem novas possibilidades educacionais, implicando novos desafios para todos os envolvidos (alunos, professores, gestores públicos, comunidade) e, portanto, implicando a reflexão sobre as práticas pedagógicas a aplicar no novo ambiente. À medida que tais tecnologias se inserem em variados projetos educacionais, é preciso analisar tais projetos e políticas ligados à área de formação de professores, uma vez que estes professores poderão observar a tecnologia não somente como mediadora do seu próprio processo formativo, mas também como elemento do processo formativo de seus futuros alunos.

Para pesquisar a formação de professores a distância, considero que a escolha de um objeto de pesquisa como o sistema $\mathrm{UAB}$, representativo do valor que vem sendo atribuído à $\mathrm{EaD}$ dentro das políticas públicas educacionais, especialmente em âmbito federal, é extremamente adequada, por sua envergadura e pelas potenciais possibilidades de generalização das conclusões. Um dos objetivos do sistema UAB é a formação de professores 
no interior do Brasil. Em particular, uma das prioridades é a formação de professores de ciências, área do conhecimento em que há déficit acentuado de professores com licenciatura na área sobre a qual ministram aulas, ou mesmo em área afim. Por esta razão, estudo a implantação e o desenvolvimento de cursos de licenciatura em Física e em Química pertencentes ao sistema UAB.

Considerando-se a natureza e a quantidade de trabalhos já publicados sobre a educação superior a distância, pode-se afirmar que esta categoria de trabalho acadêmico é extremamente importante na área de Educação em Ciências. Além disso, existem poucos registros, na literatura nacional, de trabalhos dedicados à análise de cursos superiores de formação de professores de Ciências a distância, contrastando com o grande volume de análises de cursos de Pedagogia, ou mesmo de cursos em outras áreas do conhecimento, de acordo com amplo levantamento realizado por mim junto aos principais periódicos da área de educação e do Banco de Teses da Coordenação de Aperfeiçoamento de Pessoal de Nível Superior (Capes).

Justifica-se, assim, este trabalho, tendo em vista sua reflexão teórica e metodológica sobre os fundamentos, a concepção, as formas de organização, de funcionamento e as características de um sistema de educação a distância como a UAB para a formação de professores em nível superior. Busco aprofundar os aspectos teóricos e práticos que alicerçam os cursos de licenciatura $\mathrm{EaD}$ analisados, tanto o potiguar quanto o tocantinense, desenvolvendo um estudo exploratório e analítico. Tive a intenção de contribuir para determinar as qualidades, as potencialidades, os limites e as precariedades da $\mathrm{EaD}$ e, em particular, dos cursos examinados, sem deixar de propor caminhos teóricos e práticos para o aperfeiçoamento dos programas e projetos educacionais na área de formação de professores em tal modalidade, especialmente em Física e em Química. Ao optar por cursos da região Norte-Nordeste, não somente contemplei a região onde trabalho atualmente, mas também a região que menos apresenta estudos sobre formação de professores a distância.

\subsection{Objetivos da pesquisa}

O objetivo principal desta pesquisa é o de explorar, analisando criticamente, aspectos da concepção, do planejamento, da organização, da implantação e do andamento de dois cursos de formação inicial de professores, um curso de Licenciatura em Física e outro em Química, na modalidade a distância, na UFT. Sendo o projeto dos cursos da UFT concebidos 
originalmente pela UFRN, busquei elementos das trajetórias de ambas as universidades, o que possibilitou, em muitos pontos, uma comparação direta dos processos e das produções de cada universidade.

A partir das informações resultantes deste processo de exploração e análise, procurei atingir os seguintes objetivos específicos:

- Explicitar características comuns e distintas entre os cursos analisados, trazendo à tona questões ainda não solucionadas no âmbito do desenvolvimento de cursos superiores em EaD;

- Identificar idiossincrasias dos cursos de formação de professores de Física e de Química analisados em relação a outros cursos de graduação na modalidade de EaD, possibilitando uma reflexão e, eventualmente, uma reorientação das práticas dos diversos atores do sistema;

- Analisar como o referencial freireano pode contribuir para a construção de cursos superiores em $\mathrm{EaD}$ com mais qualidade;

- Identificar possíveis ações das instituições ofertantes dos cursos que possam facilitar o alcance dos objetivos fundamentais do sistema UAB (interiorização e formação de professores);

- Apontar sugestões para melhorias na operação e no desenvolvimento de licenciaturas EaD no contexto de estados da região Norte-Nordeste.

\subsection{Metodologia de pesquisa}

O caminho metodológico escolhido para esta pesquisa foi o de pensar e o de problematizar as relações entre os diversos agentes do sistema: alunos, professores, coordenadores, tutores, orientadores acadêmicos, gestores do sistema UAB, universidades, secretarias estaduais e prefeituras associadas, coordenadores de polo e comunidades locais. Neste sentido, assim como Gouvêa e Oliveira (2006), procuro discutir a $\mathrm{EaD}$, modalidade que se associa a fatores que vão da expansão do ensino superior ao uso das tecnologias de informação e de comunicação na educação, mas que não pode prescindir do fator humano.

Desta forma, inicio este trabalho fazendo um levantamento bibliográfico sobre as temáticas que envolvem a formação inicial de professores a distância no Brasil. Passo por temas como o percurso da educação a distância, especialmente a de nível superior, no mundo e no Brasil, com destaque para o uso de TIC; a regulamentação nacional da EaD; as experiências públicas de formação de professores a distância no Brasil, incluindo o projeto 
Sistema Universidade Aberta do Brasil; as experiências específicas da formação de professores de ciências na modalidade EaD no Brasil.

Esta abordagem não poderia deixar de ser crítica e, para isto, não somente compilo fatos históricos, mas trago opiniões de autores sobre as temáticas abordadas. Frequentemente, os autores parecem dialogar e debater diretamente entre si, apesar da falta de sincronia entre os tempos em que foram escritos seus artigos e teses. Busco, assim, dar espaço ao contraditório, algo que segue sendo muito comum nas temáticas que envolvem a educação superior a distância.

Posteriormente, elaboro um relato histórico do processo de concepção, elaboração, planejamento, organização, implantação e andamento dos cursos estudados em cada uma das instituições, analisando o processo integralmente. Busco uma reconstrução destes processos a partir de entrevistas concedidas por alguns dos professores e coordenadores envolvidos, tanto da UFT quanto da UFRN, e da consulta a documentos e ao material didático dos cursos examinados, sistematizando analiticamente as representações do processo pedagógico percebidas nas entrevistas e buscando evidenciar as características dos atores e dos elementos constituintes do sistema $\mathrm{UAB}$, em especial na formação de professores de Física e de Química. No caso da UFRN, foram realizadas seis entrevistas semiestruturadas; no caso da UFT, foram quatro entrevistas; no total, as entrevistas duraram cerca de 30 horas, incluindo-se nesta estimativa eventuais respostas ou réplicas fornecidas por escrito. Na UFT, apliquei, ainda, um questionário respondido anônima e voluntariamente pelos alunos de ambos os cursos por meio do acesso à plataforma virtual, o qual foi respondido por 64 destes alunos. Nestes procedimentos, cumprimos integralmente o Código de Ética da USP (Resolução 4871, de 22 de outubro de 2001), com especial atenção ao artigo 27, que versa sobre ética em pesquisa, e seguimos as orientações dos regimentos e regulamentos da pós-graduação no âmbito da USP e, em particular, do Programa de Pós-Graduação Interunidades em Ensino de Ciências, em relação aos aspectos éticos.

A análise dos dados gerados na realização desta pesquisa foi realizada segundo referenciais teóricos baseados nas ideias de Paulo Freire e Marta Pernambuco. De Paulo Freire, tomo os conceitos da concepção problematizadora em oposição à concepção bancária, e do tema gerador, mas sem me afastar de conceitos como o da pedagogia da liberdade e da pedagogia do oprimido de forma mais ampla; afinal, destas obras saem os referidos conceitos. Acrescento, aqui, os conhecimentos da pedagogia da autonomia, que configuram uma última e pertinente contribuição de Paulo Freire. O conceito de tema gerador, presente na obra de Freire, também foi utilizado por meio de escritos de professores que aplicaram tais 
conhecimentos na formação de professores ou em outros programas educacionais que não a alfabetização, como Marta Pernambuco, Demétrio Delizoicov e José André Angotti.

Em casos específicos, e também para justificar a presença de uma seção sobre a legislação nacional da $\mathrm{EaD}$, recorro a estes documentos oficiais para basear críticas pontuais a certos processos. Deste conjunto de documentos oficiais, não fazem parte apenas leis, resoluções e portarias do MEC, mas também documentos da Capes que regem o sistema UAB e outros parâmetros, como os Referenciais de Qualidade para Educação Superior a Distância.

Assim, busco elementos que tragam um novo olhar sobre o sistema UAB e sua associação com os objetivos, características, vantagens, desvantagens e peculiaridades da formação de professores na modalidade a distância, especialmente no contexto da região Norte-Nordeste. Não pretendo, contudo, limitar-me a conclusões sobre o sistema UAB, mas busco trazer elementos que mostram que as questões analisadas nestes casos são, frequentemente, questões abrangentes, que envolvem a formação de professores em plano nacional. 


\section{EDUCAÇÃO A DISTÂNCIA: RECURSOS E CONTEXTOS}

\subsection{A educação e a tecnologia}

Um rápido levantamento da produção bibliográfica educacional já é suficiente para notar grande número de autores a defender a Educação como caminho para o bem-estar social e para a emancipação (ADORNO, 1995; FREIRE, 1996; MAGALHÃES; STOER, 2002). Controvérsia maior se encontra ao levantarmos a posição de autores em relação a uma maior aproximação entre educação e tecnologia, seja em relação ao uso dessas tecnologias, ou à sua integração ao processo pedagógico. Há defesas (LÉVY, 1993, 2009; ROSSINI, 2004) e críticas (GIOLO, 2008; BAUDRILLARD, 2003). A argumentação dos críticos, em geral, acaba sendo paradoxal, pois a sociedade mundial vem se apoiando e se desenvolvendo crescente e aceleradamente em função das tecnologias que vêm sendo criadas e integradas ao cotidiano das pessoas, alterando rotinas e formas do pensar, do relacionar e do construir conhecimento (DOWBOR, 2008).

Tajra (2008) mostra que, durante o século XIX e mesmo na primeira metade do século $\mathrm{XX}$, praticamente não havia interpenetração de tecnologias, ou seja, as fronteiras tecnológicas estavam muito bem estabelecidas. Para Drucker (1998), o indivíduo ou a empresa que conhecesse bem a tecnologia com a qual trabalhava prosperava, já que as tecnologias de uma área exerciam impactos mínimos em outras áreas. Era o auge do fordismo, da supervalorização da especialização do trabalhador. A situação verificada atualmente é muito diferente, como se percebe no caso da penetração das TIC na área da educação. O perfil do profissional mais valorizado hoje, segundo Tajra (2008), é o que sabe "lidar com diferentes situações, resolver problemas imprevistos, ser flexível e multifuncional e estar sempre aprendendo." (p.21).

O ritmo acelerado destas mudanças sociais seria marcado pelo desenvolvimento tecnológico e por uma consequente superimposição cultural, requerendo posturas diferentes para facilitar a interação entre o ser humano e o seu ambiente de forma racional. Isso porque a sociedade contemporânea seria marcada pela transitoriedade, ou seja, pela obsolescência esperada ou, talvez, planejada, pelo arcaísmo quase imediato e pela descartabilidade do conhecimento, implicando na necessidade de uma formação que priorize a capacidade de julgamento, de adaptação e de constante aprendizado (TOFFLER, 2001, 2003). 
Nesta linha, Dowbor (2010) entende que o Brasil se encontra em posição peculiar, pois, ao mesmo tempo em que possui amplo polo transnacional na região Sul-Sudeste do país, enfrentando as contradições mais avançadas, geradas pela economia do conhecimento e pela precarização que o sistema gera através de terceirização, também sofre por "suas relações de produção extremamente atrasadas que constituem heranças de outros ciclos econômicos, com ampla massa da população simplesmente excluída do acesso ao conhecimento". Para este autor, hoje, não estar excluído significa possuir nível de conhecimento muito mais amplo do que a mera alfabetização, uma das metas de Paulo Freire na década de 1960.

Mesmo autores que defendem o uso de TIC na educação, como Tajra (2008) e Cox (2008), acreditam que os professores devam ter visão crítica sobre a sua utilidade e sobre o que há por trás dos avanços tecnológicos. Para estas autoras, o homem vive do imperativo tecnológico ao se submeter, sem questionamentos, a cada nova exigência de "evolução", e se submete à lógica de mercado que o manda comprar um produto mais "moderno" ou "completo", sem avaliar se ele é portador de uma melhora real. Afinal, uma tecnologia só é tecnologia, ou seja, só se veste desta aura miraculosa e revolucionária, porque nasceu depois de nós. Aquilo que já pertencia ao mundo antes de nascermos é lugar comum, é cotidiano, e não nos damos conta de que aquilo, um dia, já foi tido como "avanço tecnológico".

Para França (2009), a percepção de que as relações entre conhecimento, tecnologia e processos de aprendizagem transcendem as salas de aula e passam, cada vez mais, por grupos sociais é um grande desafio colocado aos educadores. Daí viria a importância de compreender que ambientes tecnológicos de aprendizagem são muito mais que demonstração: constituem nova maneira de assimilar e representar novas formas didáticas e educacionais do mundo contemporâneo. Diante deste quadro, devemos questionar como usar a informática na educação, mas, não mais, se devemos ou não usar a informática na educação.

As TIC, especificamente, já se estabeleceram na maior parte dos espaços sociais e culturais atuais, transformando ações e relações sociais com conceitos como "flexibilidade profissional, velocidade tecnológica, múltiplos tempos e espaços vivenciais, desterritorialização do conhecimento, reterritorialização das interações e comunicações pessoais" (KENSKI, 2003). Para Gouvêa e Oliveira (2006), esta posição central adquirida pelas TIC as evidenciam como agentes de mudanças que provocam nos processos sociais, políticos e econômicos e, portanto, as colocam em foco de pesquisas contemporâneas nessas áreas. As mesmas autoras veem a existência de denominações como "era do rádio", "era do cinema", entre outras, como uma ideia de como as tecnologias, sejam quais forem, marcam as vidas dos que lhes são contemporâneos. 
Para Belloni (2003), se as TIC já estão presentes em todas as esferas da vida social, cabe à escola incluí-las no processo pedagógico e democratizar o acesso a elas. Mas, de fato, as TIC encontram-se cada vez mais presentes no discurso pedagógico, tanto na prática quanto na teoria educacional. Em outras palavras, as TIC são elemento definidor dos discursos contemporâneos do ensino e sobre o ensino, prevalecendo nos últimos (BARRETO, 2004). Trata-se de nova e diferenciada realidade que desafia a forma como se faz educação na atualidade (KENSKI, 2003).

Para Barreto (2004), atualmente, nos mais diferentes espaços, os mais diversos textos sobre educação teriam, em comum, algum tipo de referência à presença das TIC no ensino, embora, teriam sido atribuídos sentidos tão diversos a essa presença que não seriam recomendadas leituras singulares. De outra forma, se aparentemente não há dúvidas de que as TIC ocupam um lugar central na educação e na pesquisa em educação, também não há consenso quanto à sua delimitação. Afinal, as TIC não foram criadas para ser, exclusivamente, tecnologias educacionais, ou seja, não foram desenvolvidas visando ao seu uso em situações concretas de ensino-aprendizagem. Desta forma, as TIC são recontextualizadas na educação, implicando "apagamentos" (BERNSTEIN, 1996) que requerem uma análise da dimensão das condições e das circunstâncias nas quais ocorreram. As TIC podem ser postas, em um extremo, como elemento da estrutura de uma nova práxis pedagógica (KENSKI, 2009) ou de relações sociais inéditas, merecedoras de neologismos como "cibercultura" (LÉVY, 2009) e, em outro, uma forma de assassinato do mundo real, com a liquidação de todas as referências (BAUDRILLARD, 2003).

Entre estas posições, há a possibilidade de as TIC constituírem novos formatos para as "velhas" concepções de aprendizagem, em uma "modernização conservadora" ou, ainda, em situações particulares, determinarem diferenças qualitativas no fazer pedagógico (BARRETO, 2003). De fato, as TIC trouxeram elementos potencialmente facilitadores do processo de aprendizagem, pois tendem a otimizar tempo e espaço (FRANÇA, 2009). No entanto, esta facilidade pode ser perversa, pois induziria ao pensamento de que é desnecessária a interação que surge em qualquer situação de aprendizagem. Para Gouvêa e Oliveira (2006), é preciso ter cautela, especialmente pela falta de familiaridade com interações de padrões diferenciados no eixo espaço-tempo, o que tem consequências ainda não plenamente compreendidas em relação à sociabilidade inerente ao convívio escolar presencial.

Preti (1998) acredita que o fascínio e a sedução promovidos pelas TIC podem levar à alienação, à crença ilimitada, panaceica, de que teriam a capacidade de solucionar os problemas de aprendizagem e as dificuldades de acesso ao saber. Isto levaria a uma situação 
em que, ao se planejar situações didáticas, planos de ensino ou de curso, primeiramente se pense nas tecnologias a usar, relegando a um segundo plano seu conteúdo, seus objetivos, e até mesmo os aprendizes. Drucker (1997) sintetiza bem o pensamento possível, ao dizer que a tecnologia é importante porque permite fazer coisas novas, mas não porque permite fazer melhor as coisas velhas.

Para Tajra (2008), o sistema educacional, ao mesmo tempo em que se apropria das tecnologias de acordo com determinada ética, política, ideologia, pedagogia e didática, também produz tecnologias, muitas vezes críticas da própria tecnologia. Ainda segundo a autora, a incorporação dessa tecnologia no contexto escolar deve ser feita verificando-se os pontos de vista e o cotidiano dos docentes, dos discentes e do ambiente educacional. Aldeia ([2003?]) complementa esta posição, considerando que as TIC na educação só podem ser eficazes se ampliarem as possibilidades de interação, atentarem para maior qualidade dos conteúdos lecionados, refletirem sobre a metodologia inovadora, ampliarem as opções de aprendizagem e investirem na formação de formadores.

Portanto, conclui Preti (1998), não se trata de engrandecer nem de condenar as TIC como responsáveis por certos males da sociedade contemporânea, pois as TIC são e devem ser encaradas como meios e não fins em si mesmas, especialmente na educação. Apesar disso, as TIC não devem ser consideradas neutras, pois nelas se embutem valores, conceitos, visões de sociedade, racionalidades, conflitos, privilégios, exclusões etc. Isto exclui, portanto, a possibilidade de serem meras ferramentas, pois ferramentas não incluem tantos conteúdos políticos, sociais e pedagógicos.

Ou seja, tendo sido desenvolvidas para responder a problemas concretos, as TIC têm um conteúdo político e social. Este conteúdo, no que se refere à sua utilização na educação superior a distância, exige a nossa atenção, e é o que pretendemos fazer a seguir.

\subsection{Educacão superior a distância}

Moraes (2010) introduz o tema da EaD de forma contundente. Para o autor, afirmar que a educação representa o único caminho para a salvação do mundo e, por extensão, dizer que todos os problemas do mundo se devem às falhas da educação, poderíamos nos ver livres para endeusar ou satanizar a $\mathrm{EaD}$, seguindo convicções pessoais, uma vez que a EaD é uma modalidade de educação. Em outras palavras, não mais se trataria de pesquisar a educação ou, 
em particular, a $\mathrm{EaD}$, mas de prejulgá-la, permitindo que opiniões pessoais balizem a produção acadêmica.

Para Moraes (2010), a EaD é fator de desenvolvimento da educação como um todo, seja da educação presencial ou da não presencial, por se colocar, desde o princípio, no campo do novo, da transgressão, do desafio, do direito à tentativa e ao erro, da permissão para ousar no desenvolvimento de métodos e materiais.

A educação superior a distância não é nova. A inspiração remete a experiências alemãs e norte-americanas em estudos "independentes", algumas anteriores ao século XIX (MORAES, 2010; BARRETO, 1999; DOBES, 2003). Para Gouvêa e Oliveira (2006), a modalidade a distância ganha importância por conta das demandas socioeducativas derivadas da Revolução Industrial. Ainda assim, o modelo contemporâneo de EaD em nível superior surge apenas no fim da década de 1960, com o projeto britânico da Open University (Universidade Aberta), ainda que haja iniciativas anteriores muito semelhantes, ambas ainda ativas, como a da Universidade da África do Sul, estabelecida na década de 1950, e a da Universidade do Pacífico Sul, sediada em Fiji e atendendo a outros 11 países ou territórios na Oceania, fundada na década seguinte (GOUVÊA; OLIVEIRA, 2006).

Ao longo da década de 1970, muitas outras iniciativas surgem, em variados graus de semelhança com a proposta britânica: a Universidade Nacional de Educação a Distância (Uned) espanhola, a conversão da Universidade Athabasca canadense em instituição exclusiva de EaD, o surgimento da FernUniversität alemã e, também na América Latina, a Universidade Aberta da Venezuela e uma Uned na Costa Rica. Os principais centros irradiadores da EaD em nível superior foram a França, a Espanha e a Inglaterra, contribuindo não somente ao trabalhar para ampliar o campo de aplicação dessa modalidade, mas como inspiração ou, até mesmo, como modelo. A Open University britânica mantém um programa de consultoria, apoiando e ensinando outras iniciativas na EaD de nível superior (MORAES, 2010; BARRETO, 1999).

A partir de então e, de forma mais intensa, nos últimos 15 anos, observa-se, como fenômeno mundial, uma expansão da modalidade $\mathrm{EaD}$ no ensino superior. Esta expansão se dá de variadas formas institucionais: pela formação de instituições vinculadas ou dependentes de uma universidade tradicional; pela formação de novas instituições voltadas exclusivamente ao oferecimento de cursos $\mathrm{EaD}$; pela constituição de um órgão especial vinculado ou subordinado ao Ministério da Educação ou equivalente local; pela associação ou consórcio de diversas instituições universitárias tradicionais; pela associação entre grupos empresariais de 
tecnologia de comunicação e universidades tradicionais (MORAES, 2010; PRETI, 1998). Não só no mundo, mas também no Brasil se observam exemplos da maioria destas categorias.

A EaD teria se desenvolvido induzida pela existência de uma demanda criada por pessoas, localidades ou grupos sociais em confinamento físico ou temporal. Ou seja, indivíduos teriam a necessidade de estudar, mas a impossibilidade de espaço (pela distância ou pela dificuldade de deslocamento) ou de tempo (falta de flexibilidade de agenda, impossibilidade de presença simultânea em dois locais) teria os impedido de usufruir do ensino presencial (MORAES, 2010). Em oposição, há quem entenda que não existe demanda por $\mathrm{EaD}$, desde que haja suficiente oferta de cursos presenciais. Nesta linha, Giolo (2008, p.1217) afirma que a oferta de cursos e vagas na educação superior presencial brasileira, na década passada, "cresceu em índices elevadíssimos, não justificando, por essa razão, a presença da educação a distância enquanto oferta direta de cursos de graduação". Ao que Moraes (2010, p.30) responde dizendo que é “preciso saber enxergar outros 'confinamentos', como aqueles da 'multidão solitária', a 'aglomerada solidão' da grande metrópole - e, nela, o estudante que vive com uma agenda sobrecarregada ou tumultuada por turnos de trabalho aleatórios", entre outros compromissos.

Moraes (2010) aponta haver dois fatores inter-relacionados que criam demanda por educação flexível em tempo e espaço: aumento das expectativas de vida com redução do tempo de validade do conhecimento. Uma vez que os indivíduos não têm, mais, tempo de vida menor ou igual à validade do seu conhecimento, ou seja, sua vida dura mais que o tempo de utilidade de certo conhecimento para o trabalho que desempenham, tornam-se necessárias novas formações ao longo da vida. Nas palavras do autor, "em suas diferentes formas, a escola provavelmente deixará de ser um momento definido e fechado da juventude": o aprendizado contínuo e constante, como demanda do trabalho, incentiva a busca por educação de qualidade, mas que, ao mesmo tempo, permita ao aluno manter sua rotina e gerenciar seu tempo.

Moraes (2010) diz que se deve evitar reduzir a EaD à ideia de um ensino mediado por TIC. O conceito de EaD englobaria maneiras diversas de organização do ensino-aprendizagem, incluindo a estimulação e o apoio ao estudo independente ou solitário, mas não somente. Tal conceito também deve incluir a regulamentação do setor, afinal, afirma o autor, o sistema escolar também opera na $\mathrm{EaD}$ validando e certificando publicamente a aprendizagem dos seus alunos.

Preti (1998) destaca que, inicialmente, pressupunha-se que o aluno da modalidade EaD deveria assimilar passivamente os conteúdos, lendo o material escrito, ou ouvindo gravações, 
ou dando audiência a programas radiofônicos ou televisivos. Aos poucos, no entanto, os projetos de EaD passaram a utilizar tecnologias mais interativas, em parte pelo reconhecimento do papel ativo do sujeito no processo de aprendizagem autônoma. Em suma, para o autor, se antes importavam muito mais os resultados, na nova configuração, os processos são a prioridade. Moraes (2010) destaca que muitos dos projetos de EaD se assentam na possibilidade de liberdade no tempo, nos métodos, nas ideias, nas combinações de conteúdos e de programas. Mas o autor lembra que, juntamente com as promessas de liberdade, vêm os desafios da indefinição, da ausência de fórmulas conhecidas, além da necessidade de se reinventar os processos tão familiares da educação convencional, presencial.

Há características da $\mathrm{EaD}$ frequentemente citadas como fatores de dificuldade que devem ser levados em consideração no momento da elaboração de cursos a distância baseados em plataformas computacionais (HORTON, 2000; ALDEIA, [2003?]):

- O planejamento e o desenvolvimento de um curso a ser ministrado pela internet exige mais dedicação que um curso presencial, especialmente porque os docentes deverão ter a capacidade de responder a dúvidas de diferentes alunos, em diferentes estágios de aprendizagem;

- $\quad$ Requer mais tempo e mais esforço, por parte dos alunos, que um curso presencial;

- $\quad$ Exige um bom planejamento institucional e uma produção de qualidade acima da média;

- $\quad$ É alto o risco de se verificar altas taxas de evasão, pois os alunos temem se sentir desassistidos, visto que não há contato presencial com o docente;

- Trata-se de uma formação frequentemente citada como impessoal, de alta exigência de autodisciplina e de planejamento temporal.

Para Preti (1998), há mais um aspecto a ser levado em consideração no uso de TIC para a EaD: a tentação de buscar acompanhar as mudanças, sempre muito velozes, nas tecnologias de comunicação. Para o autor, trata-se de um risco, pois estudos teriam apontado que uma tecnologia introduzida em cursos de $\mathrm{EaD}$ exige manutenção por, pelo menos, cinco anos para ser eficaz. Ou seja, é necessária tecnologia estável, para que os atores do processo educacional possam conhecê-la, desenvolvê-la, testá-la e avaliá-la melhor.

Segundo Moraes (2010), a EaD depende de elementos que seriam menos importantes ou menos estratégicos ou de demanda menos realçada na educação presencial, por conta da presença física do professor. Entre tais elementos, estariam a autodisciplina do estudante, a capacidade autoinstrutiva, a qualidade dos materiais de autoinstrução, as formas de 
cooperação interinstitucional e o planejamento de curso. De forma similar, F.Almeida (2009) acredita que a $\mathrm{EaD}$, especialmente no ensino superior, não necessariamente vulgariza ou superficializa o ensino, mas pode servir como oportunidade para que os alunos e os professores possam ter contato e se habituar ao estudo assíncrono, com a pesquisa como forma de aprender, com a escrita como forma de expressão, com o uso de redes para a comunicação colaborativa, com a manipulação de linguagens em mutação, entre outros conhecimentos e habilidades mais raros no ensino presencial.

Por estas razões, Dourado (2008) questiona, por um lado, a adesão acrítica à adoção da modalidade $\mathrm{EaD}$, quando entendida como solução dos problemas relativos à formação universitária em um país vasto como o nosso, assim como questiona posições totalmente refratárias a $\mathrm{EaD}$, de quem só vê, nessa modalidade, forma de acelerar formação inicial e continuada. $\mathrm{O}$ autor conclui que a centralidade na discussão sobre a modalidade, ou seja, sobre a presencialidade ou a distância, tira o foco do essencial, como o projeto pedagógico, as condições objetivas de ensino-aprendizagem, entre outros fatores, sendo fundamental romper com o conceito de que a existência e o uso da tecnologia são diretamente responsáveis pela alta ou pela baixa qualidade do processo educativo.

Olhar a EaD desta forma, sem realizar pré-julgamentos, sem centralizar a discussão no acessório, ou tentar dissociar a $\mathrm{EaD}$ da educação presencial nos aspectos pedagógicos, nos permite avançar na discussão sobre a sua aplicação no Brasil. Um dos fatos que mais chama a atenção é a falta de amadurecimento que a modalidade ainda possui em nosso país. Muitas das colocações observadas na produção acadêmica sobre EaD no Brasil refletem o atraso no uso da EaD no nosso ensino superior em comparação com outros países. Na seção a seguir, levanto dados e opiniões para discutir aspectos sociais, legais e políticos da EaD brasileira no nível superior, dando sequência à emergência do tema e focando a análise nas condições locais.

\subsection{EaD de nível superior no Brasil: gestão, regulamentação e política}

Rumo à necessária massificação da educação superior no Brasil, Dourado (2008) vê algumas ações sendo desenvolvidas recentemente em nível federal, como a criação de novas universidades e institutos federais tecnológicos, a expansão de vagas em cursos já existentes, a criação de novos cursos, a expansão e a consolidação de campi das universidades federais, e programas de financiamento direto ou de subsídio à permanência de alunos em vagas nas 
instituições de ensino superior (IES) particulares. Mas, para Moraes (2010), há novos desafios e necessidades, como a expansão do ensino superior para locais externos à universidade, para públicos que não se encontram na faixa etária mais associada com o ensino universitário (de 18 a 24 anos) por razões diversas, e a EaD parece ser uma tentativa de resposta a estes desafios.

Muitos dos cursos superiores mais recentemente abertos no Brasil são oferecidos na modalidade de EaD. Em articulação com esta expansão da EaD, observou-se a redefinição das ações da Capes no campo da formação de professores e da EaD de nível superior, sinalizada mais fortemente pela consolidação do projeto da Universidade Aberta do Brasil (DOURADO, 2008). Paralelamente, observou-se um aumento substancial no número de vagas e de alunos nos cursos superiores na modalidade a distância nas universidades privadas brasileiras (GIOLO, 2008).

Mas a EaD não se faz presente no ensino superior apenas nos cursos denominados "a distância”. A portaria MEC 2253, de 18 de outubro de 2001, já havia criado a possibilidade de que até $20 \%$ da carga horária total dos cursos superiores presenciais fosse ministrada por ferramentas de $\mathrm{EaD}$. Mas foi após a regulamentação deste dispositivo, por meio da portaria MEC 4059, de 10 de dezembro de 2004, que o incentivo que se pretendeu dar em 2001 levou a mudanças significativas no panorama da educação presencial. Estas mudanças também contribuíram para incentivar a criação de cursos totalmente ministrados a distância.

Para as IES federais, a portaria MEC 873, de 7 de abril de 2006, autorizava a criação de tais cursos em caráter experimental, dando dois anos de autorização antes do credenciamento definitivo. O Ministério da Educação mostra preocupações com os problemas iniciais da $\mathrm{EaD}$ ao promover uma série de medidas regulamentadoras, como os decretos 5622 , de 19 de dezembro de 2005; 5773, de 9 de maio de 2006; 6303, de 12 de dezembro de 2007 (que altera os dois anteriores), e a Portaria Normativa $n^{\circ} 40$, de 12 de dezembro de 2007, empreendendo um sistema de avaliação que pretendia corrigir as fragilidades detectadas nessa trajetória (GIOLO, 2008).

O decreto 5622/2005 é frequentemente citado por quem deseja caracterizar a visão do Estado brasileiro sobre o que é educação a distância, como Gouvêa e Oliveira (2006). Seu artigo $1^{\circ}$ caracteriza a EaD como modalidade vinculada à utilização das TIC na mediação didático-pedagógica. Outro destaque é o parágrafo $1^{\circ}$ do artigo $3^{\circ}$, que diz que os cursos $\mathrm{EaD}$ brasileiros devem ser projetados para ter a mesma duração de seus congêneres presenciais. Se Giolo (2008) entende que, até 2003, a EaD no Brasil ainda não teria uma razão de existir 
suficientemente explícita, o decreto 5622/2005, por sua vez, deixa bastante claro os objetivos da EaD no Brasil.

O Brasil, de certa forma e lentamente, vai definindo o seu modelo de educação superior a distância. O ministro Fernando Haddad declarou em 2008 (MANZINI, 2008) que o MEC pretendia exigir carga horária presencial mínima de $20 \%$, o que, segundo o ministro, se assemelha ao modelo espanhol de EaD. Na interpretação de Giolo (2008), esta exigência de um quinto de carga horária presencial "quer dizer, indiscutivelmente, que o Ministério entende ser a atividade presencial mais efetiva e garantidora de qualidade do que a aula virtual. Nesse caso, bastam 20\%? Teremos profissionais $20 \%$ e profissionais $100 \%$ ?" (p.1231). A inconsistência lógica da afirmação levou o próprio Giolo (2010) a reconhecer, em artigo posterior, que não existem estudos que coloquem a educação presencial em vantagem ou desvantagem em relação à EaD. "Como não temos esses tais estudos científicos", afirma Giolo, "manda a prudência que o andor siga vagarosamente, pois o santo pode ser de barro" (p.1286). É o que tem ocorrido, especialmente depois de a liberdade excessiva inicial dada pela legislação ter levado à criação de cursos de baixa qualidade que tiveram de ser fechados, como veremos mais adiante.

Conclui-se, assim, que esta grande regulamentação da EaD brasileira mostra que ela não é tão aberta, ou seja, tão flexível, em termos das exigências para ingresso, das disciplinas obrigatórias e do tempo para formação quanto a $\mathrm{EaD}$ em outros países. Afinal, em outros projetos de universidades abertas, está muito presente o conceito da educação centrada no aluno, na formação continuada e contínua e na liberdade curricular. Sabe-se que educação a distância não é sinônimo de educação aberta, e o caso brasileiro ilustra bem o fato: a despeito de utilizar-se a palavra "aberta" no nome do programa UAB, não se oferecem cursos de acesso universal.

Em relação ao contexto político que baseou a expansão da educação superior a distância no Brasil, é preciso notar que, em diversos momentos históricos, surgem projetos de modificação da organização e de reordenação da gestão e da política educacional nacional. Entre os temas destes projetos estão a descentralização, a municipalização, a participação comunitária e a gestão democrática e modernizada. A Constituição Federal de 1988 estabeleceu como um dos princípios do ensino público a gestão democrática de qualidade em todos os níveis. Com isto, a Constituição institucionalizou, em âmbito federal, práticas que, pontualmente, vinham sendo levadas a cabo em alguns sistemas de ensino estaduais e municipais, devidamente respaldadas por instrumentos legais produzidos pelos poderes Executivo e/ou Legislativo locais (FREITAS, 1998). 
Em fins da década de 1990 e no início da década de 2000, o modelo de gestão educacional federal passou a buscar a redução da atuação do Estado como provedor do serviço educacional, procurando viabilizar a oferta de educação por meio de agentes não governamentais e aumentar a eficiência do Estado nos processos que permaneciam sob sua responsabilidade executiva direta. Esta política, que permeava toda a ação do Estado na esfera social, tinha como princípios a focalização e a flexibilização, priorizando-se políticas de diferenciação institucional e de avaliação (FREITAS, 1998). Souza (2007) identifica que este posicionamento coincide com o período de existência do Ministério da Administração Federal e de Reforma do Estado, que, por sua vez, coincide com a gestão de Fernando Henrique Cardoso na presidência do Brasil. Exatamente na mesma época, em 1996, a EaD como modalidade de ensino se estabeleceu como parte do sistema de educação formal brasileira, ao ser incluída como alternativa de diversificação do sistema de ensino, conforme o artigo 80 da lei 9394, de 20 de dezembro de 1996, a Lei de Diretrizes e Bases da Educação Nacional (LDB) (SEGENREICH, 2009).

Silva Júnior (2003) cita autores que entendem que, sob este ideário, na relação dicotômica colocada entre professores e tecnologia educativa, a opção sempre se faz pela tecnologia, no sentido de buscar um substituto para o professor, ou seja, busca-se uma "solução" para seus baixos salários, sua formação deficiente e outros problemas, e não um apoio à função docente. Mas, para o referido autor, isto não deve ser pensado como um fato de um único país; tratar-se-ia de um movimento mundial, com especificidades, mas com uma identidade comum, coerente com a racionalidade da transição da dinâmica social capitalista.

Para Alonso (2010),

é possível afirmar que há uma lógica na expansão do ensino superior brasileiro, claramente privatista, quantitativista e concentrada em determinadas áreas do conhecimento. A EaD não estaria, obviamente, alheia a esse fenômeno. Isto é importante para verificarmos que a contradição expansão versus qualidade da educação superior brasileira não se restringe apenas à modalidade em que se dá a oferta dos cursos. É possível evidenciar certa aceleração dessa expansão no caso da $\mathrm{EaD}$, considerando as variáveis tempo e número de alunos. Isto, contudo, não interfere na lógica antes referida (p.1324-1325).

Sabe-se que a decisão de projetar e implementar qualquer sistema de $\mathrm{EaD}$, seja público ou privado, é, também, uma decisão política, uma decisão de gestão política. No entanto, ainda que, aparentemente, existam o desejo e a vontade política, as instalações físicas, a disponibilidade para a contratação de profissionais, entre outros elementos importantes, a sua mera existência não é suficiente. Para Eliasquevici e Prado Júnior (2008), é necessário, também, haver sintonia entre os fatores que são indispensáveis e os que estão disponíveis e, para isso, é preciso conhecer a realidade na qual o processo está inserido e suas limitações. 
Assim, só seria possível avançar se houvesse políticas claras, traduzidas em planos e programas viáveis, com pleno conhecimento de todos os fatores e demais agentes envolvidos. Portanto, o sucesso de projetos de EaD seria dependente do bom planejamento e da boa administração do processo.

Os mesmos autores acreditam haver cinco objetivos ou motivações que levariam instituições e governos a investir em EaD: a) democratizar o acesso à educação; b) possibilitar uma aprendizagem autônoma e ligada à experiência; c) investir em um ensino inovador e com qualidade; d) fomentar a educação permanente; e e) reduzir o custo per capita com educação (ELIASQUEVICI; PRADO JÚNIOR, 2008). Entendemos que tais motivações descrevam adequadamente sistemas em que o governo oferece ensino gratuito. Na possibilidade de oferecer educação superior paga, um sexto objetivo ou motivação impulsiona o investimento em educação: f) a possibilidade de obter lucro ou superávit nas contas públicas. Por conta destas vantagens, todas interessantes ao gestor público, seja do ponto de vista político ou do administrativo, e também devido à regulamentação da $\mathrm{EaD}$, com a publicação do decreto 5622/2005, observa-se um significativo aumento da oferta de cursos, como se a EaD fosse de implementação simples.

Assim, questionar se a $\mathrm{EaD}$ atende a uma demanda social ou a uma demanda de mercado, ou se a EaD está ou não sedimentada política e pedagogicamente como modalidade válida para a formação de professores, não leva a respostas únicas, havendo posições antagônicas entre os autores consultados, bem como autores que não colocam tais questionamentos como pertinentes. Examino a seguir os aspectos que ligam TIC, educação superior a distância e formação de professores, focalizando suas implicações na configuração e na reconfiguração dos processos educacionais e, especialmente, suas consequências nessa formação. Volto a abrir a discussão em âmbito mundial para depois focar no caso brasileiro. 


\section{FORMAÇÃO DE PROFESSORES A DISTÂNCIA}

\subsection{Formação de professores a distância no mundo}

Segundo a Unesco (2001), embora haja um reconhecimento amplo sobre a necessidade da integração entre formação inicial, continuada e qualificação dos professores, de forma a dar sustentação a um aprendizado constante dos professores, os recursos para isto são escassos - $1 \%$ do investimento global em educação, contra $6 \%$, em média, nas áreas de indústria e comércio - e as oportunidades são raras - em muitos países, um treinamento de uma semana a cada cinco ou dez anos. Na África, por exemplo, de acordo com Clayton R. Wright $^{2}$ (apud BATES, 2010), um professor de ensino médio inicia o seu trabalho com um salário mensal de 100 dólares em Serra Leoa; em diversos países subsaarianos, um professor morre por Aids a cada duas horas; no Lesoto, o número de professores mortos por Aids é o dobro do número de formandos nas escolas de formação de professores a cada ano; em algumas áreas, os professores não recebem salários por meses, buscando, assim, um segundo emprego. O mesmo Wright, assim como Adem (2009), afirma que a África precisa de quase quatro milhões de professores em 2015 para atingir o Objetivo do Milênio, da educação primária universal e de qualidade, como definido na conferência mundial de Dakar, no Senegal, em 2000.

Wright, que trabalha em Serra Leoa, e Adem, atuante na Etiópia, também concordam que a construção de edifícios dedicados à formação de professores para suprir a demanda por profissionais até 2015 não parece factível, sendo a EaD uma opção inequívoca aos ministérios de educação africanos. Para Wright, um dos benefícios mais significativos da educação a distância no contexto de um país em desenvolvimento é o fato de que os professores podem permanecer em seu local de origem, interagindo com seus alunos, sua família e sua comunidade, aplicando imediatamente o que aprendem e economizando o dinheiro que o governo gastaria ao colocar outro profissional em seu lugar, caso o professor precisasse se deslocar a um centro de formação.

Já no início da década de 2000, a Unesco (2001) identificou, entre os seus estados-membros, a dificuldade para se atingir o Objetivo do Milênio, como definido em Dakar, mesmo com o uso da $\mathrm{EaD}$ na formação e na qualificação dos profissionais de educação.

\footnotetext{
${ }^{2}$ WRIGHT, Clayton R. Informação pessoal a Tony Bates.
} 
Assim, a Unesco pediu a especialistas em todo o mundo, em 2001, para que reportassem casos de formação de professores a distância. Estes casos puderam ser classificados em quatro categorias distintas.

A primeira é a dos países que usaram a EaD para fornecer qualificação inicial a um número significativo de professores, tanto pessoas que nunca ministraram aulas quanto professores sem formação. A Faculdade Televisiva de Professores da China e o Instituto Nacional de Professores da Nigéria têm vasta experiência nesta abordagem e se tornaram parte reconhecida e institucionalizada do sistema de educação regular de seus países. Em um programa que reflete uma política oficial no sentido de aumentar o treinamento prático, a Open University britânica iniciou um programa de qualificação de graduados que desejam iniciar-se na docência, mas que não possuem habilitação para tal.

A segunda é a que considera a formação inicial dos professores insuficiente. A EaD é, então, utilizada também para aumentar habilidades, aprofundar entendimentos e ampliar o conhecimento dos professores. Alguns programas não têm um foco estrito, enquanto outros são definidos, desde a origem, para grupos específicos. Estas formações são cursadas tanto individualmente quanto por grupos de professores instados a participar das atividades por seus empregadores ou por suas escolas. Um dos casos descritos é o do Canal Futura, fundado e operado pela Fundação Roberto Marinho e financiado por diversas empresas brasileiras. Há, também, cursos disponíveis a professores dispostos a melhorar o seu currículo acadêmico, com matrículas individuais cujo custo deve ser arcado pelo próprio interessado, como diversos cursos da Universidade Aberta Nacional Indira Gandhi, da Índia. A Universidade da África do Sul também oferece cursos nestes moldes, com licenciaturas para professores ativos sem qualificação acadêmica e também para novatos, servindo para o alcance de objetivos individuais e coletivos, como o objetivo de formar um quadro qualificado de professores. Alguns cursos são projetados para que os professores possam deter qualificações estabelecidas como novos padrões mínimos para docentes adotados oficialmente no país, como é o caso chinês.

Há uma terceira categoria, na qual a EaD se caracteriza por dar suporte a cursos de reformas curriculares cujo objetivo é o de mudar tanto o conteúdo quanto a metodologia educacional do país. Na África do Sul, o Grupo Educacional de Sistemas de Aprendizagem Abertos usa o rádio para melhorar o ensino do idioma inglês como segunda língua, servindo de suporte aos professores nesta tarefa. Na Mongólia, o rádio e o meio impresso são usados para reorientar os professores em relação às mudanças nos currículos e nos métodos de um país em transição. Em apoio a iniciativas políticas que visam a instituir o uso de TIC nas 
escolas, a Universidad de la Frontera, no Chile, usa TIC para dar suporte aos professores que ensinam este assunto.

O quarto grupo usa a EaD para o desenvolvimento da carreira do professor. Ao buscar promoção, visar a um nível de qualificação superior, aspirar a uma cadeira ou trabalhar em uma escola de formação e qualificação docente, os professores precisam adquirir novas habilidades. Um projeto multinacional da África Ocidental (Burkina Faso, Guiné, Mali e Togo) desenvolveu um programa de treinamento em gestão escolar para diretores e aspirantes.

O que há de comum à maioria dos casos apresentados é o fato de serem programas de países em desenvolvimento, havendo apenas o Reino Unido como exceção. Em realidade, as experiências dos países desenvolvidos com $\mathrm{EaD}$ são, possivelmente, muito mais amplas do que as dos países em desenvolvimento, e a quantidade de cursos ofertada, muito maior. Nos primeiros, no entanto, a oferta de cursos de formação de professores é proporcionalmente menor, especialmente se tratarmos da formação inicial. Ou seja, a EaD encontrou campo para crescer nos países em desenvolvimento justamente onde a demanda é maior: na formação de professores.

Na bibliografia estrangeira pesquisada, não há artigos que busquem contrapor a formação a distância à presencial de forma específica sobre a formação de professores, mas apenas artigos que questionam a $\mathrm{EaD}$ de maneira genérica. Em outras palavras, a formação de professores a distância não é especificamente criticada como se percebe nos artigos acadêmicos nacionais. Isto não significa que não haja reservas quanto ao uso da modalidade a serviço da formação de professores. Por exemplo, Bates (2010) lembra que o novo Plano Nacional de Tecnologia Educacional dos Estados Unidos também recomenda o treinamento em rede aos professores, para que eles também aprendam como ensinar em rede. A certificação desta modalidade de treinamento, no entanto, ainda não é francamente fornecida pelos órgãos responsáveis, por estes não acreditarem que os professores possam se qualificar a distância, mas que é, não somente, necessária, mas crucial a prática presencial.

O mesmo tipo de discussão se estabelece no Brasil, onde a formação de professores a distância também é incipiente. É sobre este tema que trato a seguir, iniciando com um histórico dos projetos pioneiros de EaD no Brasil, bem como o histórico dos dois casos mais importantes tratados nesta tese: UAB e Unitins. 


\subsection{Os primeiros projetos brasileiros}

No âmbito do MEC, as principais ações para a implementação da $\mathrm{EaD}$, ainda na década de 1990, se dirigiram à instalação de cursos de nível superior, em especial para a formação continuada de professores, como Um Salto para o Futuro ${ }^{3}$, em 1991 (BARRETO, 1997), e TV Escola, em 1996. Também houve o lançamento do Programa de Apoio à Pesquisa em Educação a Distância (Paped) e do Programa de Formação de Professores Leigos em Exercício (Proformação) (GOUVÊA; OLIVEIRA, 2006; MELO; LOBATO, 2000).

Na mesma década, houve a primeira experiência de formação inicial a distância de professores da educação Básica no Brasil: a licenciatura plena em Pedagogia para o ensino Básico, desenvolvida no estado de Mato Grosso em parceria da universidade federal local com os governos estadual e municipais. Este curso buscou inovar na proposta curricular, voltada para as séries iniciais do ensino Fundamental e não para a formação de pedagogos, e na metodologia, baseada em uma combinação de técnicas de $\mathrm{EaD}$ (materiais didáticos em texto ou audiovisuais, contato com os tutores a distância pelo computador, telefone ou fax) com atividades presenciais (tutoria individual e coletiva presencial), que levavam a um sistema descentralizado de acompanhamento dos estudantes (BELLONI, 2002).

O projeto serviu como base para a implantação piloto do Programa Proformação (MINISTÉRIO DA EDUCAÇÃO, 2006), o Programa de Formação de Professores Leigos em Exercício, levado a cabo pela Secretaria de Educação a Distância em 1999 nos estados de Mato Grosso e Mato Grosso do Sul, e depois expandido para outros estados das regiões Norte, Nordeste e Centro-Oeste com a chancela da União Nacional dos Dirigentes Municipais de Educação (Undime) e do Conselho Nacional dos Secretários de Educação (Consed) (SILVA JÚNIOR, 2003). Trata-se de uma formação de nível Médio, com habilitação para o magistério na modalidade normalista, cuja intenção, legalmente fundamentada, era a de formar professores para atuar até a $4^{\mathrm{a}}$ série (atual $5^{\circ}$ ano) do ensino Fundamental.

O Proformação já teve a implantação de sete grupos de alunos, instituições e estados (grupos 1, 2, 3, 4A, 4B, 5 e 6), além da implantação piloto. O estado do Tocantins fez parte do grupo 2, aberto em 2000, e formou, dois anos depois, 660 professores em 15 agências (polos) (ALBUQUERQUE, 2002). No total, o Proformação formou mais de 30 mil professores até 2006 em todas as regiões do País (MINISTÉRIO DA EDUCAÇÃO, 2006; LORENZONI,

\footnotetext{
${ }^{3}$ Vale citar que, de acordo com E.Barreto (1997), o programa Um Salto para o Futuro atendeu professores com formação em nível médio em todas as unidades da federação, exceto o Tocantins.
} 
2006). A maior importância do Proformação foi a de servir de experiência para outros projetos da Seed para a formação de professores.

Uma das duas iniciativas pioneiras mais amplas para a oferta de cursos de graduação EaD no Brasil foi o Consórcio de Educação Superior a Distância do Estado do Rio de Janeiro (Cederj). O Cederj teve origem em 1999, sendo formalizado em 2000 em convênio entre o governo estadual, por meio da Secretaria de Estado de Ciência e Tecnologia, as universidades públicas federais e estaduais locais, e algumas prefeituras daquele estado. Esta ideia, que, segundo Gouvêa e Oliveira (2006), era do educador Darcy Ribeiro, passou ao controle da Fundação Centro de Ciências de Educação Superior a Distância do Rio de Janeiro (Cecierj) em 2002.

Segundo a página do consórcio na internet (CONSÓRCIO..., 2012), o Cederj tem como objetivo principal buscar a interiorização do ensino superior público e gratuito no Estado do Rio de Janeiro, oferecendo EaD. As partes conveniadas têm atribuições bem definidas: a responsabilidade acadêmica dos cursos é das universidades consorciadas e de seus docentes, que preparam o projeto pedagógico dos cursos, elaboram o material didático, supervisionam a tutoria e a avaliação; à Fundação Cecierj cabe produzir o material didático, gerir a metodologia de $\mathrm{EaD}$, montar e operacionalizar os polos regionais; as prefeituras municipais que abrigam estes polos devem implantar e manter fisicamente o espaço destinado ao polo, suprindo-o de material de consumo, e remunerando o pessoal administrativo local. Ainda de acordo com Gouvêa e Oliveira (2006) e a página do consórcio na rede, o Cederj atende a mais de 20 mil alunos distribuídos em 33 polos, oferecendo 10 cursos de graduação (sendo sete licenciaturas) e uma grande quantidade de cursos de extensão, os quais, em conjunto, geram certificados de qualificação, atualização ou aperfeiçoamento.

A experiência de uma década da Fundação Cecierj na EaD faz com que seus profissionais frequentemente se envolvam com a implantação e a formação e qualificação de quadros na modalidade em todo o país. O modelo do sistema UAB, como descreveremos, foi fortemente influenciado pela experiência do Consórcio Cederj. A dinâmica da atribuição de responsabilidades entre as esferas de governo é praticamente a mesma.

A outra iniciativa pioneira em relação à criação de cursos de graduação $\mathrm{EaD}$ se iniciou em 1998, quando da criação da Universidade Virtual do Centro-Oeste, com sede na Universidade de Brasília (UnB). Esta iniciativa foi como um embrião da Universidade Virtual Pública do Brasil (UniRede) (GOUVÊA; OLIVEIRA, 2006). A UniRede, como o Cederj, também é um consórcio interuniversitário, criado em reunião entre representantes de 18 universidades, ocorrida em dezembro de 1999 na UnB. O projeto da UniRede tinha como 
motivador a percepção, de certas universidades, quanto à necessidade de "o sistema público de ensino superior ocupar e ampliar seu espaço, partindo para uma ação arrojada, inovadora, responsável e concreta, como resposta às desigualdades e injustiças no campo da educação superior" (LEITE, 2007). O projeto pretendia buscar uma política de estado visando ao alcance destas metas, bem como promover a colaboração interinstitucional na produção de materiais didáticos e na oferta nacional de cursos de graduação e pós-graduação. Acabou por reunir 82 instituições públicas de ensino superior e sete consórcios regionais que oferecem cursos EaD nos níveis de graduação, pós-graduação e extensão, sob a forma de ensino regular e/ou educação continuada. Com a criação do Sistema UAB, a UniRede se reinventou, transformando-se na Associação Universidade em Rede, entidade civil sem fins lucrativos, com sede na UnB.

Dada a experiência considerada bem-sucedida do Programa Proformação, e diante do crescimento das iniciativas para a oferta de cursos de graduação a distância no Brasil, como o Cederj e a UniRede, o Ministério da Educação iniciou diversos outros programas e projetos para a formação de professores a distância, como a Formação de Professores em Exercício na Escola Primária de Timor-Leste (Profep-Timor), iniciado em 2005 (LORENZONI, 2006) e mantido até hoje (COORDENAÇÃO..., 2012). O projeto Pró-Licenciatura, tratado a seguir, é mais um deles.

\subsection{O projeto Pró-Licenciatura}

O projeto Pró-Licenciatura buscava melhorar a qualificação dos professores da educação Básica com o objetivo de aumentar a qualidade da escolarização verificada pelo Sistema de Avaliação da Educação Básica (Saeb). Tratava-se de uma ação de responsabilidade da Seed e da Secretaria de Educação Básica (SEB), em parcerias com os sistemas estaduais e municipais de ensino e IES (MINISTÉRIO DA EDUCAÇÃO, 2005). O Programa Pró-Licenciatura se propunha a incentivar iniciativas de universidades públicas, confessionais e comunitárias para a formação de professores em exercício em licenciaturas nas diversas áreas do conhecimento tratado no ensino Médio, inclusive Física e Química, pela modalidade de EaD (SCHLÜNZEN; SCHLÜNZEN JUNIOR; TERÇARIOL, 2006), objetivando oferecer tal formação a professores ativos que não detivessem a habilitação legal para a função que ocupavam. Ou seja, o Pró-Licenciatura era um programa de formação inicial, ou seja, de primeira habilitação. 
O edital do projeto Pró-Licenciatura, cuja chamada pública foi avaliada por comissões especialmente constituídas para esta finalidade, foi lançado pela Resolução CD/FNDE 34, de 9 de agosto de 2005, embora um edital anterior, de exclusiva responsabilidade da Seed (Chamada Pública MEC/Seed 01/2004), já tivesse sido emitido em 2004. As comissões se ocuparam da análise dos projetos e da respectiva elaboração dos pareceres para dois tipos de propostas de abertura de vagas: em cursos já existentes ou pela criação de cursos novos (LEITE; MUSTARO; BARBETA, 2006).

Entre as diretrizes metodológicas e pedagógicas do programa Pró-Licenciatura (MINISTÉRIO DA EDUCAÇÃO, 2005), estão a exigência de que o professor não deixe de atuar na sala de aula para cursar a licenciatura; a valorização do tutor como agente presente na escola em que o professor atua; a diretriz para os cursos serem elaborados como etapas de um processo de formação continuada, ainda que se tratasse de uma primeira licenciatura; a observação dos resultados da formação para as escolas em que trabalham os professores-alunos que dele participam; a exigência de forte carga de leitura, incluindo contextualizações, para o professor encontrar "soluções para problemas que de fato enfrenta em sua prática docente". Entre os aspectos que caracterizariam o projeto político-pedagógico exigido pelo Pró-Licenciatura estão: voltar-se a uma escola de formação integral, consciente, cidadã e articulada; enfocar a formação da identidade do professor; articular explicitamente teoria e prática docente; oferecer formação interdisciplinar, contextualizada e alinhada com as questões da juventude e da adolescência; incluir avaliações formativas e somativas, valorizando a prática do educador em formação; usar materiais em pelo menos três suportes: impresso, vídeo e digital; incentivar o educador a compartilhar sua experiência, por meio de um diário, uma monografia e uma produção não textual, no mínimo; ampliar a formação no conteúdo da disciplina, na pesquisa contemporânea da respectiva área do conhecimento e na pedagogia; estimular e avaliar gradualmente a produção textual, a produção cooperativa e a reflexão sistemática do conteúdo aprendido, especialmente no que tange à aplicação do conhecimento à realidade local. Há, ainda, outras seções no referido documento, como "o professor que queremos" e "a escola que queremos".

Mesmo com as diretrizes mencionadas, as quais inexistiram para o sistema Universidade Aberta do Brasil, Leite, Mustaro e Barbeta (2006), que participaram do processo avaliativo das propostas submetidas pelas universidades ao MEC para o edital de chamamento do programa Pró-Licenciatura de 2005, anteriormente referido, apontam diversos problemas básicos na grande maioria dos projetos examinados. Entre eles, estão: falta de integração interinstitucional efetiva - o edital exigia propostas em grupos de universidades -; equipes 
sem experiência em EaD; busca por modelos externos, como o do Cederj, sem maiores considerações sobre a adaptação do material didático à realidade regional, diferente da fluminense; cursos baseados em material impresso, com pouca ou nenhuma referência ao uso de TIC; exigência baixa quanto à qualificação e capacitação do tutor, que poderia ter menos preparo ou experiência em sala de aula que os seus próprios alunos; projetos de cursos em que os tutores serviam de intermediário obrigatório, "blindando" os professores de serem "incomodados" pelos alunos; transformação direta dos cursos presenciais em EaD, sem uma reflexão aprofundada sobre o caráter de cada disciplina. Em relação ao próprio edital, os autores apontam que alguns grupos se aproveitaram de brechas para classificar com boa pontuação projetos muito ruins do ponto de vista didático-pedagógico. Esta lista aponta apenas os problemas vinculados à $\mathrm{EaD}$; entretanto, a lista de deficiências dos projetos é bem maior. Como veremos, muitos dos problemas dos cursos examinados são, exatamente, os listados acima.

\subsection{Sistema Universidade Aberta do Brasil}

Dourado (2008) percebe, a partir de 2005, uma complexificação dos processos de expansão na modalidade $\mathrm{EaD}$, com ênfase na área da educação, com o Ministério da Educação buscando expandir as ações das IES públicas por meio de alterações político-administrativas significativas no tocante à formação de professores. Em 2005, instituiu-se o projeto UAB, em parceria com o Fórum das Estatais pela Educação, para articular e integrar um sistema nacional de educação superior a distância. Em 2006, desenvolveu-se o curso piloto de graduação em Administração, com 10.000 vagas, como uma parceria entre a Seed, o Banco do Brasil e um conjunto de dezenas de universidades federais e estaduais. Em 2007, observou-se a consolidação do sistema UAB, que passou a ter, também, participação da Capes, de acordo com a lei federal 11502, de 11 de julho de 2007. A Capes, desta forma, herdou áreas e ações que, antes, eram de competência da SEB, da Secretaria de Educação Superior (SESu) e da Seed (DOURADO, 2008). O mesmo autor identifica um crescimento da importância do papel do Instituto Nacional de Estudos Pedagógicos Anísio Teixeira (Inep) e do Fundo Nacional de Desenvolvimento da Educação (FNDE) como espaços de acompanhamento com avaliação e financiamento da educação nacional, respectivamente, sobretudo no que se refere a projetos, programas e ações direcionados à educação básica, incluindo a formação de professores. 
Há, segundo Bates (2000), dois modelos principais de instituição a ofertar educação a distância: as de modo único, ou seja, instituições que ofertam apenas cursos a distância, tendo sido fundadas para este fim ou tendo se convertido em uma destas instituições; e as de modo duplo, instituições que ofertam cursos presenciais e a distância. Para Bates, existe uma correlação que não pode deixar de ser mencionada: as instituições de modo único são mais comuns em países de jurisdição nacional única, como o Reino Unido, a Espanha e a Nova Zelândia, enquanto as de modo duplo são mais comuns em federações, como os Estados Unidos, o Canadá, a Austrália e a África do Sul, por exemplo. A associação desta correlação com o sistema brasileiro parece perfeita, já que a Universidade Aberta do Brasil, como projeto de $\mathrm{EaD}$, é centralizada no governo federal, enquanto as instituições federadas, como as universidades estaduais e federais, atuam, também, com a educação presencial.

O sistema UAB tem como principais objetivos articular e integrar um sistema nacional de $\mathrm{EaD}$ superior, buscando sistematizar ações, programas, projetos e atividades pertencentes às políticas públicas dirigidas à ampliação e interiorização da oferta do ensino superior gratuito em nosso país (UNIVERSIDADE ABERTA DO BRASIL, 2012). A urgência de ações voltadas para o incremento do ensino universitário é inquestionável, sobretudo quando se sabe que apenas $10 \%$ dos brasileiros de 18 a 24 anos têm acesso aos cursos de graduação nas universidades brasileiras (ZUIN, 2006). Dentro desta prioridade, ainda existe uma maior, contemplada já no decreto federal 5800, de 8 de junho de 2006, que formaliza o sistema UAB: o oferecimento de cursos de licenciatura e de formação continuada de professores para a educação básica.

A dimensão do sistema UAB fica clara quando se nota a necessidade de sinergia entre os consórcios públicos dos três níveis governamentais (federal, estadual e municipal), as universidades públicas e outras entidades e órgãos interessados. As universidades, por exemplo, são responsáveis pela elaboração e manutenção dos cursos, o que inclui a organização do material didático, a aplicação e a responsabilização pelas disciplinas curriculares e a orientação dos tutores quanto à condução do projeto político-pedagógico dos cursos ${ }^{4}$.

\footnotetext{
${ }^{4}$ Para Barreto (2010), o fato de a UAB não possuir projeto pedagógico explícito confere centralidade ao "aparato tecnológico e seu uso como os responsáveis diretos pela qualidade ou não do processo educativo" (DOURADO, 2008, p.905) e a redução das TIC à educação a distância, não sendo colocada a hipótese de o MEC, em contraponto ao que foi feito com o Pró-Licenciatura, evitar se sobrepor à capacidade de as universidades elaborarem os seus próprios projetos pedagógicos - centralização esta que foi alvo de críticas, por sinal (FREITAS, H., 2007).
} 
O elemento básico para a interiorização da educação superior são os polos de apoio presencial, os quais foram definidos no decreto federal 5800/2006 como unidades operacionais "para o desenvolvimento descentralizado de atividades pedagógicas e administrativas relativas aos cursos e programas ofertados a distância” pelas IES. Assim, as prefeituras que manifestarem interesse pelo programa da UAB devem se associar à secretaria responsável pela $\mathrm{EaD}$ em sua respectiva unidade federativa para a organização do polo. Conclui-se, de acordo com a página da UAB na internet e de acordo com Segenreich (2009), que é de responsabilidade do município e/ou do Estado adequar e manter o polo com todas as condições necessárias para o seu pleno funcionamento, nos mesmos moldes do consórcio Cederj.

Assim, o sistema UAB é um projeto de grandes proporções e que, por esta razão, foi considerado decisivo para que se buscasse atingir a meta governamental de $30 \%$ dos estudantes brasileiros com acesso à formação superior até o ano de 2011 (ZUIN, 2006). De fato, segundo o Censo da Educação Superior 2010 realizado pelo Inep e divulgado em outubro de 2011, das 6.379.299 matrículas de alunos de graduação, 5.449.120 (ou 85,4\% do total) correspondem a vagas em cursos presenciais, enquanto as demais 930.179 vagas $(14,6 \%)$ correspondem a cursos a distância (INSTITUTO..., 2011a).

Para Freitas (2007),

\begin{abstract}
"a oferta de cursos e programas de educação superior a distância por instituições públicas de ensino superior, em articulação com polos de apoio presencial, nos municípios, representa, sem dúvida, ruptura com os programas de formação a distância, de curta duração, de caráter mercadológico, que perduraram até pouco tempo em nosso país. Esta iniciativa, no entanto, tem suas contradições, na medida em que privilegia a modalidade de educação a distância para a formação inicial de professores em exercício (grifo da autora)" (p.1210).
\end{abstract}

De Costa e Duran (2012), pode-se depreender o norte do gestor público por trás de cada um dos editais $\mathrm{UAB}$ de chamamento de municípios para constituir os polos. O edital UAB I teria tido uma liberdade ímpar; o UAB II teria como principal critério a distância entre polos - tratar-se-ia de um edital criticado pelo fato de as distâncias serem relativas, especialmente relativas quanto à densidade populacional -; o edital UAB III teria sido, no contexto, o mais lógico, por impedir absurdos como um município $\mathrm{X}$ vizinho a $\mathrm{Y}$ já aquinhoado com um polo ser selecionado para receber outro.

Para entendermos melhor como o MEC chegou ao Sistema UAB como base para a formação pública de professores a distância, vale olhar para o Plano Nacional de Educação (PNE) da década 2001-2010, aprovado pela lei 10172, de 9 de janeiro de 2001. O referido PNE tratava abertamente da EaD superior no Brasil. Uma das metas, inclusive, era a de 
“estabelecer um amplo sistema interativo de educação a distância, utilizando-o, inclusive, para ampliar as possibilidades de atendimento nos cursos presenciais, regulares ou de educação continuada", prevendo, também e em curto prazo, a formação de uma universidade aberta. A palavra "distância" aparece 37 vezes nesse documento. Em relação à formação de professores a distância, o PNE 2001-2010 tinha a meta de "iniciar, logo após a aprovação do Plano, a oferta de cursos a distância, em nível superior, especialmente na área de formação de professores", em consonância com o que as universidades planejavam, via UniRede, apresentada como "um canal privilegiado de capacitação do magistério, através da oferta de cursos a distância" (BARRETO, 2010).

Já o projeto do novo PNE, referente ao período 2011-2020, é bem mais sintético do que o anterior, só contendo a palavra "distância" três vezes, sendo uma em referência à educação de jovens e adultos, outra em referência à educação técnica de nível médio e uma última em referência à criação de cursos de pós-graduação stricto sensu a distância. Portanto, não há nenhuma referência à formação de professores a distância, embora haja um entendimento de que a EaD é "via privilegiada e quase exclusiva para equacionar o problema da formação inicial da juventude egressa do ensino médio, nos cursos de formação de professores, em substituição às atuais licenciaturas e pedagogia” (FREITAS, 2007, p.1216). Vale lembrar que a base para a confecção do PNE 2011-2020 foi a Conferência Nacional de Educação (Conae), ocorrida em abril de 2010. No documento final da Conae, havia muitas referências negativas ao uso de $\mathrm{EaD}$ na formação de professores, como, por exemplo, considerá-la como uma solução emergencial (CONAE..., 2010, p.80), além de, logo depois, o documento afirmar que a "formação inicial deverá se dar de forma presencial" (p.83). A controvérsia acadêmica e, especialmente, política de tal afirmação pode ter implicado na ausência de qualquer referência ao uso de EaD para formar professores no novo PNE.

De certa forma, a nova postura não surpreende pela cautela em assumir como política pública permanente a formação de professores na modalidade a distância, especialmente a formação inicial, já que a lei federal 11502/2007, que atribuiu à Capes a responsabilidade pelo programa $\mathrm{UAB}$, restringiu parcialmente o uso da modalidade EaD para a formação inicial, ao estabelecer, em seu artigo $1^{\circ}$ (que altera o artigo $2^{\circ}$ da lei 8405 , de 9 de janeiro de 1992), que, "na formação inicial [...], dar-se-á preferência ao ensino presencial, conjugado com o uso de recursos e tecnologias à distância", e que "na formação continuada [...] utilizar-se-ão, especialmente, recursos e tecnologias de educação à distância”. O decreto federal 6755, de 29 de janeiro de 2009, que institui a Política Nacional de Formação de Profissionais do Magistério da Educação Básica, segue a mesma direção: o inciso VI do artigo $3^{\circ}$ afirma que é 
objetivo "ampliar o número de docentes atuantes na educação básica pública que tenham sido licenciados em instituições públicas de ensino superior, preferencialmente na modalidade presencial”, enquanto o parágrafo único do artigo $7^{\circ}$ assegura que “a formação inicial [...] dará preferência à modalidade presencial".

Dada a preferência pela modalidade presencial imposta pelo decreto federal 6755/2009, a Capes criou o Programa de Ações Articuladas do Plano Nacional de Formação de Professores da Educação Básica (Parfor), o qual oferece cursos nas duas modalidades: presencial e a distância. O sistema UAB se integra, atualmente, ao Parfor, especificamente na oferta dos cursos a distância. Giolo (2010), então, reconhece a importância do sistema, e afirma que

\footnotetext{
“a UAB é uma forma essencialmente pública de operar educação a distância, seguindo os caminhos normais das instituições públicas, ou seja, financiada pelos recursos do Estado e oferecida gratuitamente à população. Não toma atalhos. Além de coordenar e conferir organicidade às ações de $\mathrm{EaD}$ das instituições federais de educação, deverá servir de parâmetro para as demais instituições oficiais que atuam ou pretendem atuar com educação a distância.” (p.1285)
}

De fato, a forma como a UAB opera acabou por servir de parâmetro para avaliar a qualidade da $\mathrm{EaD}$ em âmbito nacional. Mas o autor pretendia fazer um contraponto à postura de tornar a EaD uma forma de se ganhar dinheiro fácil, sem preocupação com a qualidade de ensino. Veremos a seguir um destes casos: a Unitins.

\section{5. $\underline{\text { O caso Unitins }}$}

No Tocantins, além da UAB, do governo federal, a Unitins, do governo estadual, também tem um histórico notável na $\mathrm{EaD}$, especialmente para a formação de professores. Trata-se, portanto, de uma experiência que tem grande valor para o nosso estudo, especialmente pela relação estabelecida entre a Unitins e a UFT, bem como pela associação que os tocantinenses costumam fazer entre $\mathrm{a} \mathrm{EaD}$ e a Unitins.

A Unitins tem origem na Universidade do Tocantins, criada em 1990 como uma fundação estadual de direito público. Já em 1992, a universidade passa a ser considerada uma autarquia do governo estadual, incorporando as duas faculdades estaduais instaladas no antigo norte goiano, nas cidades de Araguaína e Porto Nacional (SOUZA, 2007; PRETTO; PEREIRA, 2008). Pretendeu-se, no início da história da Unitins, que a universidade se mantivesse isolada das influências político-partidárias existentes no estado do Tocantins. Uma das ideias era a de constituir um Conselho Comunitário com poder de deliberação sobre a 
estrutura superior da instituição, incluindo a escolha do reitor, o que seria uma inovação para o ensino superior das regiões do Centro-Oeste e Norte do Brasil. No entanto, esta intenção nunca saiu da etapa de plano: pouco tempo depois, já a partir de 1992, tornaram-se rotineiras negociações políticas para a criação de cursos e campi universitários (PRETTO; PEREIRA, 2008).

Em 1996, a universidade foi administrativamente extinta, e seu patrimônio foi absorvido pela Fundação Universidade do Tocantins, constituindo-se, desde então, como uma fundação de direito privado. Nesse momento, a Universidade transformava-se numa “instituição pública, mas não estatal”, de "direito privado, mas não particular", de acordo com o texto da lei estadual 872, de 13 de novembro de 1996. Assim sendo, a Unitins passou a cobrar mensalidades de seus alunos por padrão, permitindo que eventuais alunos que se considerassem carentes solicitassem redução parcial ou total das mensalidades (SOUZA, 2007; PRETTO; PEREIRA, 2008). Com isto, o Tocantins foi o único estado que concretizou o temor, muito presente nas pessoas e na imprensa durante na gestão de Fernando Henrique Cardoso na presidência, de cobrança de mensalidades de alunos de graduações presenciais em sua instituição estadual de ensino superior. A própria universidade teria sido "posta à venda" em anúncio do governo estadual no jornal Correio Braziliense de 18 de março de 2000 (PRETTO; PEREIRA, 2008).

Até então, a trajetória da Unitins "é a expressão de uma concepção patrimonial de Estado cuja descontinuidade é um traço marcante e que as decisões não se efetivam em critérios estritamente acadêmicos", segundo Moretz-Sohn (2002). Esta autora ainda aponta exemplos de situações a que a Unitins foi submetida: sucessivas mudanças de personalidade jurídica, rotatividade das reitorias, fechamento e abertura de cursos e campi, diversidade de vínculos empregatícios, entre outras intervenções. A insatisfação da comunidade universitária era crescente e culminou, em 2000, no movimento SOS Unitins, encabeçado pelos estudantes, que resultou na reestruturação do ensino superior do estado e, conforme determinava a lei estadual 1160 de 19 de junho de 2000, na isenção de contrapartidas financeiras. Naquele mesmo ano, foi criada, no papel, a UFT, a qual acabou absorvendo parte do patrimônio da Unitins e de seu alunado de cursos presenciais apenas em 2003 (PRETTO; PEREIRA, 2008).

No mesmo ano de 2000, a Unitins iniciou uma reestruturação, visando a se preparar para a perda dos cursos para a UFT. A estratégia foi a de promover cursos de graduação e de pós-graduação lato sensu a distância na modalidade telepresencial, ou seja, com salas de aula providas de televisores que transmitiam as aulas por satélite diretamente da sede da instituição, na capital Palmas. Para isto, a Unitins firmou contrato particular de prestação de 
serviços educacionais e de cooperação técnica com a Sociedade Civil de Educação Continuada Ltda. $\left(\right.$ Eadcon $^{5}$ ) para desenvolvimento de cursos de graduação e pós-graduação na modalidade de EaD. Pelo contrato firmado entre a Eadcon e a Unitins, a Eadcon participaria fornecendo conhecimento técnico e equipamentos, enquanto a Unitins se incumbiria da elaboração do projeto educacional e pedagógico, bem como pelas demais atividades da vida acadêmica (BRASIL, 2008).

Apesar de a Unitins já ter promovido dois cursos, em janeiro e em julho de 1998, dentro de um Programa de Formação Docente em Regime Especial, com professores que não tinham como comer ou onde dormir durante esta formação, por falta de recursos (PINTO, 2007), uma brecha no artigo 21 da lei estadual 1160/2000 permitiu à Unitins voltar a cobrar mensalidades dos interessados na formação dada pelo convênio Eadcon/Unitins - o referido artigo só garantia a gratuidade dos cursos já em funcionamento à época, mas não aos que porventura fossem posteriormente criados. Mais: as mensalidades eram descontadas diretamente do salário, no caso de o aluno ser professor da rede estadual, já que havia um convênio entre a Secretaria de Educação do Estado e a Unitins (ARAÚJO, 2008). O decreto estadual 1672, de 27 de dezembro de 2002, confirmou a decisão, determinando que o que havia sobrado da Unitins se constituísse, novamente, em universidade paga ${ }^{6}$.

A Eadcon/Unitins ofereceu, inicialmente, o curso Normal Superior em salas instaladas em 64 dos 139 municípios do Estado (MOREIRA, 2009), número que chegou a 118 com o curso de Pedagogia, implantado posteriormente, sendo a primeira instituição de ensino superior brasileira a atuar com esta metodologia (PINTO, 2007). Em 2004, a portaria ministerial MEC 2145, de 16 de julho de 2004, credenciou a Unitins para ofertar cursos de graduação a distância, com a autorização do Curso Normal Superior a distância, com seis mil vagas a serem oferecidas em todo o Brasil, onde quer que a universidade mantivesse um polo presencial. Portanto, foi a partir de 2004 que a Eadcon/Unitins passou a atuar em todo o território nacional, chegando, efetivamente, a oferecer cursos em todas as unidades da federação, com mais de 250 polos regionais (MOREIRA, 2009), e com diversos cursos de graduação, como Administração, Pedagogia, Letras, Matemática, Serviço Social, Ciências Contábeis, Análise de Sistemas, entre outros (ALMEIDA, M., 2009).

\footnotetext{
${ }^{5}$ De acordo com Pinto (2007), a empresa era conhecida, inicialmente, pela sigla Educon, passando a se chamar Eadcon quando da aquisição de parte das cotas da empresa, em 2007, pela Universidade Estácio de Sá.

${ }^{6} \mathrm{O}$ caso de cobranças de mensalidades de alunos de EaD não é único no Brasil. A Universidade do Estado de Santa Catarina (Udesc) esteve em situação semelhante, "privatizando" o oferecimento de cursos a distância. Segundo Giolo (2010), a Udesc vem sendo condenada a devolver os valores pagos a título de mensalidades.
} 
A Unitins oferecia seus cursos de maneira peculiar: os polos de apoio presencial se desdobravam em "centros associados", ou seja, salas de aula conectadas ao satélite de transmissão televisiva (MOREIRA, 2009), mas sem a estrutura mínima de um polo e, portanto, sem registro no MEC. Tratava-se de uma espécie de franquia da Eadcon, já que, segundo Silva (2009), tais salas de aula não pertenciam à Eadcon. A Eadcon/Unitins chegou a ter mais de 1600 salas de aula recebendo o seu sinal em todo o país, o que levava o número de alunos por tutor variar entre 2500 e 12000 , dependendo do curso e da disciplina (MOREIRA, 2009). O mesmo autor aponta que todos os professores e tutores da Unitins eram contratados, tendo, portanto, seu trabalho regido pela Consolidação das Leis do Trabalho (CLT), e não pelo regime único dos servidores estaduais. Pinto (2007) também afirma que, à época, as teleaulas não eram geradas a partir da sede da Unitins, mas da sede da Eadcon, localizada em outro prédio de Palmas.

Tudo isto mostra que a Unitins, na prática, somente emprestava à Eadcon o seu nome, o seu registro e a facilidade de, por ser uma universidade estadual, criar cursos e ser regulada e fiscalizada pelo próprio governo do estado do Tocantins. Até mesmo os contratos dos alunos se faziam com a Eadcon, o que, na visão do MEC, era um procedimento ilegal, tendo em vista que os mesmos eram alunos da Unitins, uma universidade estadual, e o inciso IV do artigo 206 da Constituição Federal garante a gratuidade do ensino público em estabelecimentos oficiais (CONSELHO NACIONAL DE EDUCAÇÃO, 2009).

Por conta deste fato e de denúncias realizadas ao MEC pelo Conselho Federal de Serviço Social e pelos alunos do "centro associado" de Paranaiguara, extremo sul goiano, em outubro de 2008, uma batalha jurídica se estabeleceu entre a Unitins e a Seed. A Seed passou a investigar a Unitins, encontrando muitas outras irregularidades na instituição de ensino, como a falta de contato direto entre professores e alunos, assim como a falta de contato entre a Unitins e os polos e "centros associados", e acabou por expedir a nota técnica de supervisão 37/2008. Uma das descobertas mais extravagantes foi a de que a "parceria" entre Eadcon e Unitins se dava com a Unitins como contratada e a Eadcon como contratante, ou seja, com a empresa privada colocando a entidade pública a seu serviço (CONSELHO NACIONAL DE EDUCAÇÃO, 2009).

A Seed, em fevereiro de 2009, conseguiu impedir cautelarmente a realização de novos vestibulares na $\mathrm{EaD}$ da Unitins, por sugestão do Ministério Público Federal do Tocantins (BRASIL, 2009). A Unitins passou a alegar que não poderia conceder gratuidade a todos os alunos, pois o governo local não poderia ser obrigado a subsidiar a graduação de alunos de outros estados. Diante do impasse, a Seed optou por submeter ao Conselho Nacional de 
Educação a sugestão de descredenciamento da Unitins, o que ocorreu em outubro de 2009 (CONSELHO NACIONAL DE EDUCAÇÃO, 2009), embora os alunos matriculados tenham mantido o direito de prosseguir estudando na Unitins e receber os seus diplomas, ainda que pagando mensalidades (MOREIRA, 2009), por meio da portaria MEC 44, de 18 de agosto de 2009.

Um movimento de reestruturação da instituição foi articulado. Posteriormente, a Unitins obteve o seu recredenciamento para a oferta de cursos de graduação EaD, agora gratuitos, por meio do sistema UAB, conforme portaria MEC 837, de 24 de junho de 2010, com lançamento do primeiro edital de seleção de alunos em dezembro de 2010 (PERERIA, 2010). Carlos Eduardo Bielschowsky, que viajou a Palmas para acompanhar a cerimônia de lançamento do referido edital, em sua carta de despedida do cargo de secretário de Educação a Distância do MEC, ocorrida em 31 de dezembro de 2010, comemorou o descredenciamento dos cursos Eadcon da Unitins, realizado integralmente em sua gestão (BIELSCHOWSKY, 2011).

\subsection{Posicionamentos quanto à formacão de professores a distância}

No processo de expansão recente do nível superior público brasileiro, destaca-se a expansão da oferta de cursos de formação de professores, o que pode ser visto como um passo importante para a melhoria da qualidade da educação no país. Entre as políticas que se associam a esse setor estão a diversificação e a diferenciação da educação superior; a criação de institutos de ensino tecnológico superior, oferecendo pelo menos $20 \%$ de suas vagas para a formação de professores, de acordo com a lei federal 11892, de 29 de dezembro de 2008; a aprovação de diretrizes curriculares nacionais; a criação de programas para a formação docente inicial e continuada; a criação da Rede Nacional de Formação Continuada de Professores (ainda existente e vinculada ao Parfor); as mudanças nas políticas de financiamento, favorecendo o crédito para o pagamento de cursos de licenciatura em IES privadas (DOURADO, 2008).

Os referidos programas e políticas se viram, muitas vezes, marcados pela superposição e, em alguns casos, por dinâmicas contraditórias em relação às concepções que as orientam. Juntamente com esta questão, a formação de professores na modalidade $\mathrm{EaD}$ vem sendo alvo de muitas discussões acerca de sua pertinência e qualidade, entre outras questões (DOURADO, 2008). É isto o que pretendemos abordar e discutir aqui, já que, como afirmam 
Mota, Chaves Filho e Cassiano (2006), o nível de formação docente é fator de influência decisiva em relação ao desempenho dos estudantes e, assim sendo, é vital a existência e o desenvolvimento de políticas públicas que criem oportunidades de formação de qualidade aos que buscam atuar no magistério. Para Leite, Mustaro e Barbeta (2006), a criação de cursos de licenciatura $\mathrm{EaD}$ em todo o Brasil, públicos e privados, acompanha o ocorrido em outros países em desenvolvimento, ainda que seguindo modelos e concepções distintas.

Há autores (TOSCHI, 2008; KENSKI, 2008; BELLONI, 2001) que afirmam que não se deve olhar para as modalidades presencial e a distância como antagônicas, mas complementares. Belloni (2001) considera que a questão fundamental está na capacidade de inovação nos conteúdos e nas metodologias, na busca dos sistemas de ensino por soluções para os problemas antigos e para os novos, em especial àqueles relacionados com novas formas do aprender. Moraes (2010) considera um desafio tirar proveito da massificação e evitar seus efeitos deletérios. Para o autor, tais formas industrializadas de ensino coexistem ou mesmo facilitam aprendizagens extremamente flexíveis e individualizadas nos conteúdos e nos ritmos, permitindo um diálogo mais frequente entre aprendizes e professores. Para Dourado (2008), romper com a dicotomia entre as duas modalidades permite pensar políticas articuladas para a formação, evitando posições extremas e, muitas vezes, irracionais em favor ou contra cada uma. Aquele autor entende que as bases para se garantir a qualidade estão em um projeto pedagógico que possibilite uma sólida formação teórico-prática, professores formadores com grau mínimo de mestre, oferta adequada de laboratórios, bibliotecas e material didático-pedagógico e, nos cursos a distância, acompanhamento, por meio de encontros presenciais regulares e com o uso de TIC.

Leite, Mustaro e Barbeta (2006) acreditam ser relevante que a política nacional de formação de professores incorpore características oferecidas pela incorporação das TIC. Tais autores destacam a possibilidade de surgimento de uma cultura de parcerias entre as instituições, que leve em consideração a prática pedagógica dos professores em formação, envolvendo toda a comunidade educativa, com criação de materiais didáticos diferenciados, conscientização da responsabilidade e do controle que a autonomia requer, e direção que integre gestão e projeto pedagógico. Tais características se refletiriam na flexibilidade e ampliação do acesso à aprendizagem, na redução da necessidade de locomoção de alunos e professores, na capilaridade na oferta, na competência da equipe e no controle e avaliação da aprendizagem no ritmo do aluno (MUNDIM, 2006). Além disso, afirmam Santarosa et al. (2005), em uma sociedade tecnológica como a contemporânea, os professores precisam não somente se apropriar das tecnologias, como fazer uso delas, tanto no ensinar quanto no 
aprender, com qualidade similar à educação presencial. No entanto, para Alonso (2010), há uma ilusão do atendimento massificado, relacionada à ideia de autonomia absoluta do aluno na $\mathrm{EaD}$, ou seja, que bastaria o fornecimento dos dispositivos (laboratórios, bibliotecas, material didático etc.) para os alunos aprenderem.

Quanto à dificuldade de fazer chegar as TIC e seus aspectos pedagógicos aos docentes que mais precisam dela, Belloni (2002) fala da experiência do estado de Mato Grosso, abordada anteriormente. A autora destaca que a primeira turma de 300 alunos, titulada após quatro anos (em 1999, portanto) com índices de evasão muito baixos, manteve-se coesa, muito provavelmente, graças às políticas públicas de valorização dos professores. Os entes federativos asseguraram condições para estudo individual e coletivo dos professores no local de trabalho, estimulando a motivação que, segundo Alonso (1999), é necessária à aprendizagem. No entanto, Silva Júnior (2003) percebe que, em geral, a valorização dos professores dá enfoque à sua capacitação instrumental, e não ao seu papel social, formativo, o que, ao menos parcialmente, explicaria o modelo de competências predominante nos cursos de formação.

$\mathrm{Na}$ literatura, no entanto, não é difícil encontrar críticas mais pesadas à $\mathrm{EaD}$ a serviço da formação de professores. Para Barreto (2004), esta redução das TIC no seu modo de incorporação e, portanto, nos sentidos que esta incorporação assume, mostra o esvaziamento da formação de professores, transformada em mera "capacitação em serviço" ou até "reciclagem", “com as considerações pedagógicas nas margens e as questões de fundo obliteradas" (BARRETO, 2004, p.1191), enquanto a formação inicial presencial, desprovida do mesmo financiamento, não garantiria, sequer, o acesso às tecnologias. Para Freitas (2007), a priorização da $\mathrm{EaD}$ na formação de professores vem ocorrendo em detrimento do reforço às licenciaturas presenciais, que vem sendo reformuladas desde a aprovação das Diretrizes Curriculares para Formação de Professores, em 2002, e dos cursos de Pedagogia, em 2006. Obviamente, esta crítica deve ser levada com muita cautela, afinal, as licenciaturas a distância não eliminam ou mesmo se opõem às presenciais. Além disso, os cursos de Pedagogia se concentram, em grande parte, em instituições privadas, especialmente os cursos em EaD, ao contrário das licenciaturas. A forma de financiamento e os objetivos institucionais e instrucionais, portanto, são diversos.

Barreto (2004) contrasta as propostas de uso das TIC na educação superior dos países em desenvolvimento em relação aos países desenvolvidos, baseada em sua avaliação dos diversos números da revista TechKnowLogia. Para a autora, tal revista indica que, nos países desenvolvidos, o uso de TIC pretende agregar novas possibilidades aos processos 
pedagógicos, enquanto em países como Brasil, Uganda e Vietnã, tal uso configura estratégia de substituição tecnológica, nas quais a ênfase é colocada na formação de professores a distância, o que, por sua vez, se relaciona à certificação em massa, sem preocupação com o aspecto do aprendizado. Mais uma vez, é preciso relativizar a crítica, pois não é possível generalizar a qualidade dos diversos cursos $\mathrm{EaD}$ existentes no país. A própria criação do sistema UAB, posterior à crítica feita pela autora, indica um amadurecimento dos referenciais de qualidade para a EaD no Brasil.

De forma mais flexível, Freitas (2007) traz a posição da Associação Nacional pela Formação dos Profissionais da Educação (Anfope), favorável à apropriação das TIC, tanto na formação inicial quanto na continuada, por considerá-las meios, instrumentos e mecanismos para ampliação da vivência democrática, mas com a ressalva de que as TIC não podem ser vistas como um valor em si, mas como parte de uma educação fundada na realidade.

Dourado (2008) coloca algumas questões que ele vê como importantes para a reflexão, neste momento de mudanças nas políticas de formação, em que se busca concretizar um sistema nacional de formação de professores, reivindicação histórica no campo educativo. São elas:

- $\quad$ Por que a Capes dividiu o enfoque da formação de professores em duas diretorias (uma presencial e outra a distância)?

- Que conceito de formação de professores norteia as ações da Capes?

- $\quad$ Por que a Capes e o MEC buscam consolidar o sistema UAB num momento em que se discutem as bases para a estruturação do sistema nacional de formação de professores?

- Qual é o papel da SEB e da SESu nesse processo de mudança?

- Qual o papel reservado à Seed nesse contexto?

- Seria a $\mathrm{EaD}$, por meio da $\mathrm{UAB}$, um ensaio de novas formas de articulação política, formas que busquem garantir a regulamentação da colaboração entre os entes federados?

Algumas das respostas a estas questões são encontradas em ações posteriores à época em que Dourado expressou suas apreensões, como a instituição da Política Nacional de Formação de Profissionais do Magistério da Educação Básica, pelo decreto 6755/2009, e a extinção da Seed, ocorrida em janeiro de 2011, com a respectiva incorporação de suas ações pela Capes e pelas demais secretarias do MEC. No entanto, o próprio artigo de Dourado (2008) reconhece que a transferência da responsabilidade da formação de professores para a Capes foi um primeiro passo para a unificação de atribuições que, antes, ficavam espalhadas pelas várias secretarias do MEC. 
A última pergunta colocada por Dourado (2008) merece uma consideração especial. É, no mínimo, preocupante que a EaD possa ter servido de cobaia para o teste de políticas públicas. A EaD ainda é incipiente demais no Brasil para servir a tais fins. Mais grave é quando percebemos que a responsabilidade que a ela foi imputada, a formação de professores, é grande demais para ser posta em risco. A faceta mais visível do fracasso desta colaboração é vista na avaliação dos polos levada a cabo pela Seed em 2010, a qual só considerou satisfatória a estrutura de 5,9\% dos 556 polos vistoriados (COSTA; DURAN, 2012). É preciso pensar em alternativas, como a transferência dos polos para as universidades ou a vinculação de percentual das verbas do Fundo de Manutenção e Desenvolvimento da Educação Básica e Valorização dos Profissionais da Educação (Fundeb) para a estruturação e a manutenção dos polos.

Para Freitas (2007), esta política de formação de professores, ao entender a equidade como igualdade de oportunidades em lugar de igualdade de condições, oferece formação diferenciada aos educadores, já que os cursos na modalidade $\mathrm{EaD}$, para a autora, não oferecem o "lócus privilegiado para a formação de qualidade elevada de todos os educadores" (p.1207), representado pelas universidades, seus centros de educação e suas articulações intra e interinstitucionais. Trata-se da mesma crítica levada pela Anfope à audiência pública do Conselho Nacional de Educação que discutia diretrizes da formação inicial em 2001 (ANFOPE, 2001). A mesma autora vê, nas propostas de licenciaturas $\mathrm{EaD}$, uma redução da fundamentação epistemológica e científica e a prevalência de uma concepção conteudista e pragmática de formação, com base na epistemologia da prática e na lógica das competências.

Todas estas críticas devem ser olhadas com muito cuidado. Inicialmente, devemos estar atentos à diferença entre os sistemas de EaD dos diversos países: no Brasil, por exemplo, já há uma restrição significativa à possibilidade de esvaziamento da $\mathrm{EaD}$, uma vez que ela não é aberta, e segue praticamente as mesmas regras do ensino superior presencial, incluindo o tempo de formação. Outra diferença, já destacada anteriormente, é o fato de, nos países em desenvolvimento, a EaD ser intensamente - em alguns casos, prioritariamente - utilizada para a formação de professores, o que não ocorre nos países desenvolvidos. Por fim, como reforço à ideia de que a dicotomia entre educação presencial e a distância é menos pedagógica e tecnológica, mas muito política, especialmente no Brasil, Alonso (2010) entende que não se pode examinar a expansão da EaD sem observar a expansão geral do ensino superior brasileiro, para poder elaborar políticas públicas adequadas para a formação de professores.

É o que faz Giolo (2010), ao citar diversos documentos e pronunciamentos da Associação Brasileira de Educação a Distância (Abed) e de seu presidente, Fredric Michael 
Litto e rememorar os casos da Unitins e da Universidade do Estado de Santa Catarina (Udesc). Naquele artigo, Giolo entende que a iniciativa privada pressiona o poder público para uma desregulamentação (ou uma fraca regulamentação) da $\mathrm{EaD}$, permitindo, assim, modelos extremamente flexíveis para a modalidade. De fato, as diretrizes da Seed, ao consolidar instrumentos de avaliação que exigem, por exemplo, polos claramente constituídos como espaços escolares e o cumprimento de uma carga horária presencial mínima, configuram um modelo brasileiro para a EaD, o que, segundo Giolo, a Abed considera um rígido bloqueio à criatividade.

Há, ainda, críticas de outras naturezas. Giolo (2008), por exemplo, entende que, uma vez que os professores atuarão na educação presencial, não podem ser formados por modalidade que não seja a presencial, limitando-se a cursos em $\mathrm{EaD}$ na formação continuada. Belloni (2003) se coloca contra este discurso descolado de evidências geradas por pesquisas da área de educação, especialmente em relação à insistência em opor entre educação presencial e a distância:

Em primeiro lugar, pensemos no fator distância, que tem sido utilizado como definidor dessa modalidade de ensino e cujas significações estão longe de ser unânimes. De fato, a relação professor/estudante, especialmente no ensino superior, sempre foi mais coletiva que individual e muito assimétrica. "O anfiteatro, modelo da sala de aula, grande e superlotado, organizado em torno e focalizando a cátedra, era o símbolo perfeito desta distância" (Trindade, 2000). Então de que distância falamos quando dizemos educação a distância? (p.290)

Também é importante lembrar que, independentemente de o curso de formação inicial de professores ser presencial ou a distância, o estágio obrigatório nas escolas é necessariamente presencial. Desta forma, a parte prática da formação não é diferente em uma modalidade ou em outra. Obviamente, a qualidade deste estágio pode e deve ser discutida. Mas, se falta qualidade ou pertinência ao estágio no atual formato, e se se faz necessária uma reforma da prática na formação inicial de professores, tal reforma é tanto necessária aos cursos presenciais quanto à $\mathrm{EaD}$.

Para F.Almeida (2009), rebatendo outro ponto do discurso de Giolo (2008), os cursos de licenciatura, mesmo presenciais, não contam com material e com currículo que discutam e preparem os professores para uma eventual educação continuada a distância, ou mesmo que preparem estes futuros educadores para o domínio das questões que cercam a EaD. Barreto

\footnotetext{
${ }^{7}$ TRINDADE, Armando Rocha. Enseigner en présenciel et à distance. In: Journées Réseaux humains/Réseaux technologiques: présence à distance: actes et rapports pour l'education. Poitiers: Université de Poitiers/CNDP, 2000 .
} 
(2004) alerta que, sem uma formação adequada nas TIC, tanto por parte dos docentes quanto dos alunos, não há a condição necessária à sua apropriação como parte do processo educativo.

No que caímos em outra crítica: Barreto (2004) chama a atenção para a precarização do trabalho docente em certos usos de TIC. Para a autora, em cursos semipresenciais, não há um redimensionamento de carga horária e remuneração dos professores, de forma a incluir o tempo despendido na interação virtual; ao contrário, as TIC facilitam processos de subcontratação e de terceirização. No caso das instituições públicas, informa Alonso (2010), devido à forma como se financiam os projetos de cursos $\mathrm{EaD}$, as vagas geradas nessa modalidade não são computadas no total da oferta da instituição. Ou seja, os alunos da EaD são excluídos da matriz orçamentária das instituições e, na prática, seus cursos não são a elas incorporados, o que, segundo a autora, tem gerado problemas e distorções, como o financiamento e a sobrecarga do trabalho docente.

Especificamente sobre o trabalho docente, em muitas instituições, questiona-se o aproveitamento das horas despendidas em atividades didáticas ou administrativas nos cursos $\mathrm{EaD}$ como equivalentes a horas empregadas em atividades homólogas em cursos presenciais. É frequente que conselhos e instâncias superiores universitárias desprezem o trabalho sob a justificativa de que o professor já recebe um valor adicional pelo trabalho adicional e, portanto, que o tempo dedicado à $\mathrm{EaD}$ não deva ser considerado para fins institucionais ou funcionais. No caso do financiamento dos cursos, este é restrito aos anos de integralização do curso, o que leva ao desrespeito dos ritmos de aprendizagem dos alunos, já que não há, na maior parte das instituições, normas que possibilitem o prolongamento da estada do aluno, diferentemente do que ocorre com o ensino presencial (ALONSO, 2010). São críticas pertinentes que discuto mais adiante.

É preciso destacar que existem referenciais de qualidade dos cursos superiores na modalidade a distância, definidos pela Seed desde 2007 (MINISTÉRIO DA EDUCAÇÃO, 2007), bem como um instrumento de avaliação dos cursos de graduação na modalidade, definido pela portaria MEC 1326, de 18 de novembro de 2010. De acordo com tais documentos, o curso superior em EaD precisa cuidar, especialmente, de seus objetivos, conteúdos curriculares, material didático, avaliação dos alunos, titulação e regime de trabalho docente, qualificação dos professores em $\mathrm{EaD}$, dedicação exclusiva de parte dos docentes à $\mathrm{EaD}$, disponibilidade do acervo bibliográfico básico e laboratórios. A existência de tais referenciais facilita a aceitação da $\mathrm{EaD}$ como modalidade possível para a formação de professores. 
Em relação aos alunos da EaD, observa-se uma altíssima taxa de evasão, especialmente quando se compara esta modalidade de ensino com a modalidade presencial. Adem (2009), que trabalha em um instituto da Unesco responsável pela promoção de cursos de formação de professores em IES africanas, investigou as razões da evasão elevada, e percebeu que:

- muitos dos alunos ingressantes já possuíam grau de instrução equivalente ao que pretendiam obter (por exemplo, faziam uma segunda graduação ou pós-graduação lato sensu); - em algumas universidades, os alunos dos cursos a distância não consideraram que recebiam um apoio adequado da instituição;

- $\quad$ a quantidade de trabalho envolvido em alguns dos cursos estava além da capacidade ou do tempo disponível para a sua consecução.

Adem (2009) tirou outras lições da experiência: uma delas, a de que algumas instituições não cumpriam o acordo de incorporar o programa financiado à sua estrutura, e os cursos terminavam assim que o financiamento da Unesco também chegava ao fim; outra lição foi a recusa da validação dos diplomas emitidos pelas universidades por parte das autoridades educacionais do país, muitas vezes meramente por não ter informações suficientes sobre os cursos $\mathrm{EaD}$, seu nível de rigor, as determinações internacionais de qualidade, entre outras.

Mesmo assim, há quem defenda a EaD não somente como a melhor segunda opção de formação inicial e continuada de professores, para além da formação presencial tradicional, mas, talvez, a melhor e mais barata. É o caso de Moon (2008), que identifica dois desafios mundiais, expandir as oportunidades educativas e prover professores e educação de qualidade aos professores, sendo que as TIC e a EaD, para ele, seriam formas flexíveis e eficientes de se fazer isto, merecendo ser compartilhadas, experimentadas e avaliadas mundialmente. No caso específico da formação de professores de ciências, área cujo déficit de profissionais costuma ser ainda maior, a EaD merece uma consideração especial. É o que faço a seguir.

\subsection{Formacãão de professores de ciências a distância}

Antes de olharmos para os aspectos específicos da formação de professores de ciências a distância, trago um breve levantamento de pontos notáveis quanto à formação de professores de ciências, independentemente da modalidade.

Comecemos por Delizoicov, Angotti e Pernambuco (2007), que tratam de seu princípio de visão acerca das orientações que um ensino de Ciências contemporâneo deve ter. 
Para estes autores, a Ciência e a Tecnologia devem ser abordadas pelos docentes de forma a serem incorporadas criticamente pelos alunos, de forma a se constituírem como cultura, em oposição à ideia da "ciência morta"; devem ser incorporados os conhecimentos científicos contemporâneos e as novas tecnologias na educação em Ciência e Tecnologia; é necessária uma aproximação entre a pesquisa em ensino de Ciências e a formação de professores de Ciências, para que os novos conhecimentos produzidos nas universidades se convertam em uma educação científica ampla e renovada; por fim, os autores entendem ser necessário superar as insuficiências do livro didático, sendo adequada, para isto, a utilização mais ampla e natural de livros, revistas, jornais, programas de televisão educativos ou de divulgação científica, produções multimídia para computadores, e a própria internet como material didático, além da utilização de espaços de divulgação científica e cultural como oportunidades educativas não dissociadas dos momentos de aprendizagem escolar ${ }^{8}$.

Ou seja, não basta que os professores conheçam regras, receituários, taxonomias etc., já que, segundo aqueles autores, a apropriação de conhecimentos, por parte do aluno, não ocorre pela mera transmissão mecânica de informações. Delizoicov, Angotti e Pernambuco (2007) destacam haver um desafio novo, representado pela expansão do público escolar e pela mudança nas formas de socialização e expressão, nos valores e na contextualização sociofamiliar do alunado; tal desafio não poderia ser enfrentado com as mesmas práticas utilizadas pelos docentes no passado. Entraria, também, neste contexto, as tendências da pesquisa em ensino de Ciências, que mostraram a necessidade de abandonar o ensino voltado para a formação de cientistas e incorporar no objetivo de ensino o pressuposto da "Ciência para todos". Na mesma linha, Del Carlo (1997) concorda que considerar as Ciências em seu aspecto indissociável de processo humano implica, entre outras coisas, levar em conta as necessidades humanas relativas aos contextos econômico, político e social onde as Ciências se encontram e como estes contextos influenciam em sua construção.

Embora, como já discuti nesta tese, EaD não signifique, necessariamente, o uso de TIC, esta associação é cada vez mais frequente nos cursos na modalidade a distância implantados recentemente, inclusive nos cursos que estudo aqui. Assim, vale olhar para o que tem sido pesquisado sobre a interação entre educação científica e TIC. Meleiro e Giordan (1999) entendem que o diálogo estabelecido entre as ciências e as TIC "está provocando verdadeiras mudanças nas produções do imaginário, como atestam as condutas científicas

\footnotetext{
${ }^{8}$ A visão destes autores concorda e amplia as Diretrizes Curriculares Nacionais para a Formação de Professores da Educação Básica (Resoluções CNE/CP 1 e 2, de 18 e 19 de fevereiro de 2002, respectivamente) para a área de Ciências.
} 
vigentes e as experiências de ensino em andamento" (p.20). Giordan e Gois (2009) apontam que as atividades realizadas em ambientes virtuais representam uma forma de inserção nas ciências, razão pela qual aqueles autores apoiam o desenvolvimento de tais ambientes para que se integrem a uma organização curricular alinhada às demandas cognitivas e sociais da sociedade contemporânea. Por fim, segundo Ferrari, Angotti e Tragtenberg (2009), a mediação por TIC abre possibilidades ao uso de linguagens adequadas à aprendizagem de temas contemporâneos característicos do desenvolvimento das Ciências.

De fato, são inúmeros os objetos de aprendizagem desenvolvidos para ensinar Ciências com o uso de TIC, e diversos autores defendem a sua utilização (MELEIRO; GIORDAN, 1999; GIORDAN; GÓIS, 2004). Mas tais aplicativos de simulação ou sistemas tutoriais não esgotam as possibilidades de uso do computador para o ensino de Ciências. Para Giordan (2005), é possível incentivar o também o diálogo dos alunos entre si, de duas formas, usando TIC: na presença do computador e, também, por meio do computador. E, se estes elementos têm alterado até a forma de ensinar Ciências presencialmente, não há como dizer que as mudanças tratadas pelos autores não permeiem a EaD na formação de professores de Ciências. Tanto é assim que, afirma Giordan (2005), a comunicação mediada por computador tem sido uma das formas de uso mais pesquisadas no contexto da educação escolar, especialmente após a disseminação do uso da internet.

Neste contexto, afirmam Delizoicov, Angotti e Pernambuco (2007, p.147), o professor de Ciências Naturais é um privilegiado profissional da escola, à medida que está mais habituado ao uso de recursos tecnológicos, tanto pela sua formação quanto pela quantidade de material de sua área de estudos disponível por meio de redes de computadores. Para aqueles autores, o uso de tais recursos e o conhecimento de como selecionar e reagrupar informações permitem a aquisição de habilidades importantes na contemporaneidade. Por outro lado, até mesmo estes professores mais "antenados" evitam aproximar as TIC da sala de aula. Para Geremias, Cima e Angotti (2005), tratar-se-ia de mais um conflito instaurado na educação, muitas vezes levando ao atraso na oferta e na formação de educadores e educandos nas linguagens inerentes às TIC. Giordan (2005) conclama a comunidade de Educação em Ciências a não se omitir, ocupando seu papel de interlocutora preferencial da sociedade neste momento de ruptura paradigmática, em que se exige uma definição sobre as formas de uso das TIC na educação em Ciências, pois o referido autor entende que é pelo diálogo que os mitos serão despidos.

Entretanto, se, cada vez mais, fica claro não ser possível desprezar a influência e a importância das TIC no ensino de Ciências, por outro, ter o conhecimento pedagógico do 
conteúdo na respectiva área e domínio das TIC não basta para ser um bom professor de Ciências. Em relação a isto, afirmam Delizoicov, Angotti e Pernambuco (2007), que

"Se é consensual e inquestionável que o professor de Ciências Naturais, ou de alguma das Ciências, precisa ter o domínio de teorias científicas e de suas vinculações com as tecnologias, fica cada vez mais claro, para uma quantidade crescente de educadores, que esta característica é necessária, mas não suficiente, para um adequado desempenho docente. A atuação profissional dos professores de Ciências no ensino fundamental e médio, do mesmo modo que a de seus formadores, constitui um conjunto de saberes e práticas que não se reduzem a um competente domínio dos procedimentos, conceituações, modelos e teorias científicos" (p.31-32).

Uma das capacidades que este professor deveria ter, dentro do conceito freireano do tema gerador, sobre o qual tratarei no próximo capítulo, é a de saber ressignificar conhecimentos trazidos à sala de aula pelos educandos. Para não nos limitarmos a Paulo Freire, vejamos Carvalho e Gil-Pérez (2011) e sua discussão acerca daquilo que configuraria características do bom professor de Ciências em termos de conhecimentos e capacidades. Seguem as nove habilidades elencadas:

I) Romper com visões simplistas sobre o ensino de Ciências;

II) Dominar os conteúdos a ensinar;

III) Questionar as ideias de "senso comum" sobre o ensino e a aprendizagem e, mais especificamente, sobre o ensino e a aprendizagem das Ciências;

IV) Adquirir conhecimentos teóricos sobre a aprendizagem das Ciências;

V) Saber analisar criticamente a educação "tradicional";

VI) Saber preparar atividades capazes de gerar aprendizagem efetiva;

VII) Saber dirigir as atividades dos alunos;

VIII) Saber avaliar de forma a promover o avanço dos alunos;

IX) Ter conhecimento suficiente para poder associar ensino e pesquisa didática.

Se um professor de Ciências precisa saber de tudo isto, não é possível imaginar que o estudo solitário na formação desse professor possa significar $100 \%$ do tempo de estudos em $\mathrm{EaD}$. Ou seja, deixar os alunos, futuros professores, sem um acompanhamento adequado de suas atividades levará a uma situação em que dificilmente ocorrerá a aprendizagem de tantas capacidades necessárias ao bom professor. Para Meleiro e Giordan (1999), a direção a ser seguida deve ser sinalizada pelo professor formador, que deve fornecer aos alunos orientações que lhes permitam potencializar as informações e os recursos oferecidos pelas TIC, dando-lhes o subsídio necessário para alicerçar a construção do conhecimento.

$\mathrm{Na}$ mesma direção, segue Cunha (2006), que afirma que a EaD exige didática, ferramentas de ensino e modelos pedagógicos específicos da modalidade. Fernandes (2007) complementa, afirmando que a formação de professores de Ciências de qualidade mediada 
por TIC exige um sistema de ensino atualizado e adequado ao aproveitamento dessas tecnologias. Cunha (2006) finaliza, afirmando que, qualquer que seja o projeto pedagógico, a $\mathrm{EaD}$ depende da disponibilidade de material adequado ao modelo pedagógico e às mídias que se pretenda utilizar, especialmente para Ciências Exatas.

Projetos de formação de professores de Ciências a distância têm princípios diversificados, embora compartilhem essa essencialidade tratada no parágrafo anterior. De acordo com Fernandes (2007), no curso de licenciatura em Física da Universidade Federal de Santa Catarina (UFSC), por exemplo, são três os princípios-âncora: interação, cooperação e autonomia. Além disso, entre outros alicerces, deve constar um projeto pedagógico consistente, voltado para o aluno da EaD e não para o aluno de cursos presenciais.

As dificuldades para a construção desse projeto diferenciado são inúmeras, e o caminho a trilhar ainda é longo para que tenhamos as respostas que a EaD exige. Lacerda Neto e Silva (2002), por exemplo, apontam a mediação das TIC no ensino de Ciências como um caminho para o desenvolvimento de competências importantes à formação de cidadãos autônomos e críticos, ainda que entendam que esta mediação tenha se limitado a ilustrar princípios científicos em artefatos tecnológicos e, portanto, não tenha inovado o suficiente para modificar o ensino tradicional, como o excesso de exposições e o predomínio de problemas fechados.

Para Fernandes (2007), a internet pode representar um importante instrumento de formação de professores de Física e Ciências. Contudo, o autor vê como o dilúvio de informação existente na rede dificulta a sua utilização efetiva pelos professores, o que demandaria uma organização dos conteúdos adequados ao uso nos cursos de formação desses professores. Conclusão semelhante obteve Lima (2009) acerca da formação de professores de Ciências a distância no estado do Pará. Para esta autora, "a ineficiência não está na falta de computadores ou de infraestrutura adequada, mas sim na falta de hábito ao se apropriar da rotina recomendada para a metodologia via internet" (p.9).

Braga e Bueno (2009), ao atuar no curso de licenciatura em Química EaD de universidade privada do litoral paulista, concluíram que o professor de Ciências Exatas deve estimular a produção textual de seus alunos, atentando para as individualidades, bem como deve desenvolver ferramentas e estratégias para refletir sistematicamente sobre a produção textual do curso. Ou seja, deve analisar a produção de seus alunos tanto quanto a sua própria, favorecendo a metacognição neste meio que, ao mesmo tempo em que incentiva a produção textual, dificulta a expressão na linguagem própria das Ciências, devido às limitações dos ambientes virtuais. 
Fernandes (2007), ao tratar especificamente do ensino de Física na modalidade a distância, traz o seguinte pensamento:

Ensinar Física na modalidade a distância não é tarefa fácil. As metodologias utilizadas estão em constante mudança e transformação - todos estão aprendendo. Há a necessidade de o professor ser menos presencial e mais virtual, e o aluno em descobrir como ser mais autônomo. O tutor equilibra os dois extremos do sistema didático - professor e aluno -, sem ter tempo para descobrir qual é o seu verdadeiro papel. Ele tenta, da melhor forma possível, administrar o processo de aprendizagem, articulando saberes e tempo de aprendizagem do aluno. (p.227)

Assim, fica claro que a formação de professores de ciências a distância tem vantagens e desvantagens muito particulares da modalidade, e que caminhos possíveis para aumentar a qualidade e o aproveitamento dos alunos é utilizar com sabedoria os momentos presenciais, de forma a atenuar justamente os aspectos desvantajosos da $\mathrm{EaD}$, bem como explorar melhor os aspectos inovadores desta modalidade, evitando-se os vícios da chamada "educação tradicional". 


\section{REFERENCIAIS TEÓRICOS E METODOLÓGICOS}

A partir deste ponto, explicito os referenciais teóricos que dão sustentação às análises e trabalhos realizados na produção, organização e compreensão dos dados, trazendo, também, análises críticas desses marcos teóricos, que destacam seus pontos positivos e negativos. Basicamente, são referenciais pensados por Paulo Freire e por Marta Pernambuco, contextualizados para a pesquisa que se conduziu. Neste capítulo, também aponto as metodologias que alicerçam a pesquisa realizada e suas variações.

\subsection{As ideias de Paulo Freire}

$\mathrm{Na}$ obra de Paulo Freire, encontramos diversas referências que podem ser úteis à formação do professor e ao entendimento deste educador em relação a esta formação. De acordo com Freire (2009), a formação do professor é fundamental, podendo proporcionar uma educação libertadora, problematizadora ou uma educação bancária, massificada. No caso da formação a distância, uma perspectiva conscientizadora e dialógica implicaria entender de forma crítica o uso de TIC na educação, para que as intervenções do docente sejam mais políticas e éticas, mas de uma ética a serviço das pessoas, do ser mais, de visão ontológica, e não de uma ética permeada pelos maus valores capitalistas (FREIRE, 2005a).

Para Freire (2007), a raiz da educação seria a reflexão do homem sobre si próprio em certa realidade, em uma busca constante pela autorreflexão, descobrindo-se, assim, como um ser inacabado que está em constante busca, que vê a educação como uma resposta da finitude da infinitude, pela qual chegaria à perfeição ao ver-se como um ser inacabado. Mas, como isto exigiria uma busca do homem pela sua própria educação, não sendo, desta forma, seu objeto, Freire conclui que ninguém educa ninguém. Ao contrário, todos se educam socialmente, em comunhão com outras consciências, com outros seres que também procuram ser mais, através de uma superação constante, com pessoas que não se colocam na posição do superior que ensina a um grupo de ignorantes, mas na posição humilde de quem comunica um saber relativo. Freire $(2007 ; 2009)$ entende que o educando não pode ser passivo no processo formativo, tornando-se um "depósito do educador", mas sim deve se tornar capaz de criar e de transformar o mundo, como sujeito da ação, o que exige liberdade, democracia e consciência, 
possível somente por meio de um ato de amor e coragem que partiria do debate e da análise da realidade.

Afirma Freire (2007) que o homem está "no mundo" e "com o mundo", e é por isso que pode buscar distinguir-se entre um eu e um não eu, que pode relacionar-se, pode sair de si, projetar-se nos outros, transcender, captando uma realidade e fazendo dela objeto de seus conhecimentos. O mesmo autor afirma que é esta a razão pela qual a consciência reflexiva deve ser estimulada, pois quando o educando reflete e compreende sua realidade, levanta hipóteses sobre o desafio dessa realidade, busca soluções, procura transformá-la com seu trabalho criando um mundo próprio, consciente do seu eu e de suas circunstâncias. Assim, para Freire, a educação é tanto mais autêntica quanto mais desenvolve o lado criador do homem, que conhece a sua identidade e é ele mesmo, portador de consciência crítica que lhe permite transformar a realidade, responder aos desafios do mundo e fazer sua história pela criação e pela decisão própria. Em oposição a este ser crítico e consciente, Freire (2007) afirma que um ser alienado é um ser inautêntico, não por causa da imitação em si, mas pela passividade com que recebe essa imitação ou pela falta de análise ou de autocrítica.

Em relação ao conceito de comunicação na obra de Paulo Freire, Schneider (2008) entende que o mesmo tem ligação com a coparticipação dos sujeitos no ato de pensar, em uma relação de reciprocidade que não pode ser corrompida. Em suma, o que caracterizaria de forma adequada a relação entre comunicação e educação seria o diálogo, pois, para Paulo Freire, a educação é comunicação, é diálogo, nunca transferência de saber, mas sim um encontro de sujeitos interlocutores que procuram significar significados. Na mesma linha, Pernambuco (1994, p.28) lembra Paulo Freire, ao mostrar que um aluno, como parceiro educando de um educador, retoma um processo de produção de conhecimento em sala de aula com o diálogo, por excelência, como o instrumento desta produção. Mas a mesma autora afirma que, para esta comunicação efetivamente ajudar o educando a sentir-se como sujeito digno de respeito em seu mundo, capaz de atuar nesse mundo, é preciso que o educador valorize seletivamente o conhecimento do aluno e de sua forma de pensar.

Afirma Schneider (2008) que Paulo Freire referiu-se especificamente à comunicação uma única vez, em 1968, em um ensaio intitulado "Extensão ou comunicação?”, de objetivo duplo: criticar as atividades de extensão de agrônomos e servir de base para uma discussão de especialistas sobre reforma agrária. Nesse ensaio, Freire (1977) explicita a ideia de que “extensão" se associa a transmissão, transferência, invasão, enquanto "comunicação" está ligada às ideias de reciprocidade, de coparticipação dos sujeitos no ato de conhecer e, mais profundamente, à própria existência do ser humano como um ser necessariamente social. 
Freire também aproveita para reforçar o entendimento de que o educador e o educando estabelecem uma relação de diálogo, uma relação igualitária, referida ao objeto cognoscível, e não uma relação em que o objeto é "depositado" pelo educador no educando. Tratar-se-ia, portanto, de uma reciprocidade que não permite ruptura, já que o sujeito pensante não pode pensar um objeto sem a participação do outro sujeito.

Schneider (2008) entende que a atual sociedade exige mudanças significativas na forma de educar, como, por exemplo, uma substituição da transmissão unidirecional de informação pela troca interativa entre os sujeitos da aprendizagem. De fato, não se trata de novidade, mas de uma admissão da necessidade do diálogo como proposto por Freire e de um entendimento de que a EaD oferece uma oportunidade singular para esta exigida migração de uma pedagogia de transmissão para uma pedagogia do diálogo. A mesma autora entende ser necessária a adoção de uma ideologia de educação continuada e centrada no aluno, na qual "formar é muito mais do que puramente treinar o educando no desempenho de destrezas [...]" (FREIRE, 1996, p.14), rejeitando-se o ensino "bancário" (FREIRE, 2005a), entre outras mudanças de paradigmas.

Um pouco mais sobre a importância do diálogo na relação educativa é discutido e aprofundado por Freire em "Pedagogia do Oprimido" (2005a). Defende o educador pernambucano que a dialogicidade está na essência de uma educação como prática da liberdade e como fonte de libertação do oprimido. Trata-se da comunicação como diálogo, do amor como fundamento ${ }^{9}$, da autossuficiência como tabu, da confiança recíproca como valor maior, e do ser humano como ser de relação. Na mesma obra, Freire explicita que o diálogo autêntico é o reconhecimento do outro, é o reconhecimento de si próprio no outro, é a expressão de uma decisão e de um compromisso de colaborar para a construção do mundo, é a humanização da consciência de seres que dialogam.

$\mathrm{Na}$ mesma obra, Freire aponta os limites para que este diálogo aconteça. Entre estes limites está a impossibilidade de diálogo entre opressor e oprimido, já que o primeiro tem por objetivo a imposição de ideias e não a sua discussão; a inexistência do diálogo como embate entre pessoas em busca de uma única verdade, ou como simples troca de ideias prontas para ser consumidas; a insustentabilidade de um diálogo que não seja fundado no amor, na humildade e na fé humana (SCHNEIDER, 2008).

\footnotetext{
${ }^{9}$ Para Ramacciotti (2010), "[ao] falar de amor e amorosidade, categoria que percorre a vida e a obra de Paulo Freire, ele rompe com qualquer perspectiva piegas. Na concepção freireana, amar é dialogar para libertar. [...] A amorosidade, em Freire, representa um ato de coragem, de libertação e de compromisso com homens e mulheres." (p.27)
} 
Uma das formas de abertura ao diálogo é proposta pelo próprio Freire, ao conceituar o tema gerador na mesma obra, "Pedagogia do Oprimido" (2005a). Nessa obra, Freire aprofunda a ideia de diálogo e de palavra geradora, esta última usada na alfabetização de adultos, como na experiência de Angicos (RN) e outras que se seguiram (GERMANO, 1997). Com isto, Freire propõe uma nova forma para a concepção de programas de ensino, pois com o uso de temas geradores, o educador vislumbrava uma forma de devolver ao povo os elementos fornecidos aos educadores-educandos em um formato organizado, sistematizado e ampliado e, em especial, que permitisse a mudança social.

Ao contrário do que possa se imaginar à primeira vista, a estruturação do programa educacional com estas bases e a definição dos temas geradores deve ocorrer antes do início das atividades de estudo sistemático; ou seja, da mesma forma como ocorre com a maior parte das demais metodologias, não há espontaneísmo nem improvisação ou adiamento para o início da interação educador-educando a definição dos tópicos a trabalhar. O que o conceito de tema gerador traz de novo e de inédito é a introdução do diálogo já na fase de elaboração dos programas, portanto sem uma prefixação dos tópicos de estudo por parte de quem conduz o processo de elaboração destes programas ou de seus interesses pessoais ou corporativos. Ao contrário, Freire propõe uma interação plena e elaborada entre uma equipe interdisciplinar e a população que participará do processo ensino-aprendizagem em busca conjunta de situações e tópicos significativos e de interesse coletivo, bem como de sua sequência e de sua articulação (FREIRE, 2005a; PERNAMBUCO, 1994).

Com base no trabalho e nas ideias de Paulo Freire, ou seja, redimensionando aqueles ideais para uma prática escolar, diversos projetos fizeram uso de temas geradores dentro do sistema de educação formal. Entre eles estão um aplicado na Guiné-Bissau (DELIZOICOV, 1982); outro no município de São Paulo (PERNAMBUCO, 1994); e duas propostas no Rio Grande do Norte, sendo uma de ensino básico (PERNAMBUCO et al. ${ }^{10}$, 1988, apud PERNAMBUCO, 1994) e a referida proposta para as licenciaturas em Física e em Química da universidade federal local.

Para Delizoicov (1982), há cinco etapas de passagem obrigatória para a elaboração de um programa pedagógico baseado no conceito de tema gerador, em um processo comumente denominado investigação temática. A primeira dessas etapas trata de um levantamento preliminar da realidade local, com coleta de material, conversa com a comunidade,

\footnotetext{
${ }^{10}$ PERNAMBUCO, Marta Maria Castanho Almeida et al. Projeto Ensino de Ciências a partir de problemas da comunidade. In: SEMINÁRIO CIÊNCIA INTEGRADA E/OU INTEGRAÇÃO ENTRE AS CIÊNCIAS: TEORIA E PRÁTICA, 1988, Rio de Janeiro. Atas... Rio de Janeiro: Editora da UFRJ, 1988.
} 
investigações de campo, além de uma busca por fontes secundárias, dados estatísticos e de administração pública, entre outras fontes.

A segunda etapa compreende a análise do material coletado, buscando encontrar as relações entre as falas que expressam a percepção da comunidade e de seus membros, e as demais informações obtidas. A intenção desta etapa é a de encontrar elementos significativos para aquele grupo social, algo considerado como uma dificuldade a ser superada, mas que, ao mesmo tempo, possibilite uma compreensão de outros elementos associados a esta dificuldade e que se insiram em um contexto mais amplo. Nesta etapa, todos os educadores devem discutir e contribuir com o seu conhecimento particular para o surgimento de alguns temas que tenham potencial interdisciplinar e que possam ser tidos como possíveis temas geradores.

Uma terceira etapa inclui o que Paulo Freire denomina "círculo de investigação temática", no qual os temas potenciais são codificados na forma de situações vivenciais associadas a tais temas e apresentados ao público-alvo, qual seja os educandos e seus familiares. Pernambuco (1994) entende ser esta a fase de testar se, de fato, os temas e situações escolhidos são significativos para aquela população.

$\mathrm{Na}$ quarta etapa, as falas do círculo de investigação temática são estudadas pelo grupo de educadores, de forma a ser examinadas e discutidas por especialistas no ensino de cada área do conhecimento de forma individual, mas, ao mesmo tempo, de forma articulada, interdisciplinar. Aqui se inicia a redução de temas.

Por fim, a quinta e última etapa é a do trabalho sobre os temas, com cada professor planejando as suas atividades e as confrontando tanto com os pares da mesma série quanto com os próprios alunos, que também são chamados a discutir e opinar sobre a lógica do programa naquilo que lhes cabe.

Obviamente, tal forma de abordagem dos conteúdos requer planejamento e um grande esforço de organização da escola, já que o planejamento deve ser iniciado ainda no período letivo anterior. Ainda assim, não é um programa rígido, sendo aberto às mudanças que o dia a dia da prática escolar demanda, ou seja, é um programa a ser constantemente refeito e reelaborado ao longo do percurso.

Pernambuco (1994) entende inevitável repensar os conteúdos em dois sentidos: em relação aos instrumentos que tais conteúdos fornecem aos educandos e de como estes conteúdos interagem com as necessidades e as possibilidades individuais e coletivas de educandos e educadores. A autora afirma que o currículo deve implicar uma noção mais ampla, extrapolando os limites da grade curricular, avançando para ouvir a comunidade; ultrapassando a função de transmissora de conteúdo e colocando em pauta questionamentos 
sobre como, por quê, do quê e para quê. Isto exigiria atenção para pontos tidos como essenciais: o trabalho coletivo, a formação dos educadores, a metodologia baseada no diálogo e o programa escolar.

Entende Pernambuco (1994), com base em Freire (2005a) e Delizoicov (1982), que a compreensão da realidade, ainda que provisória e incompleta, se associa à possibilidade do distanciamento. Ou seja, para que possamos rever o nosso comportamento, para que possa haver transformações em nossa sociedade, além de existir um conflito real, é preciso que tenhamos consciência desse comportamento; consciência esta que exige um olhar externo, distanciado. E isto se daria na exploração das contradições do real, das diferentes falas associadas ao real, da construção coletiva e individual do real, do questionamento constante do real. Desta forma, buscar o tema gerador, compreendendo o que é significativo nas dimensões analítica e vivencial, e trabalhar a partir desse tema, para a autora, seria trazer à tona contradições para superá-las, buscando novos conhecimentos a todos os participantes, em uma construção coletiva.

Neste processo, é preciso fazer a mesma diferenciação que Freire $(2005 b, 2011)$ faz entre tomada de consciência e conscientização. A primeira limita-se a uma aproximação sem teor crítico, ao contrário da segunda, mais plena, por permitir não somente a tomada de consciência, mas um tipo de conhecimento que desvela a realidade e, até mesmo, uma utopia crítica. Portanto, a visão que o educador deve ter é a de buscar a conscientização, e não se satisfazer com uma mera tomada de consciência dos participantes do processo educativo. Para Pernambuco (1994), ainda que a educação não seja o elemento determinante, pode servir de instrumento importante para a ocorrência de transformações sociais. Mas, para isto, precisaria dar ao educando um acesso efetivo ao conhecimento, algo que lhe permita agir sobre o mundo em que vive, inserindo-se nesta complexa e mutante sociedade.

\section{2. $\quad$ A visão de Marta Pernambuco e outros}

Para compreendermos mais um pouco da visão de Marta Pernambuco, que liderou a confecção do projeto pedagógico dos cursos de graduação a distância da UFRN, reproduziremos um trecho dos Cadernos de Formação, no volume "Visão da Área" de Ciências da Secretaria Municipal de Educação de São Paulo (SME-SP), liderada por Paulo Freire de janeiro de 1989 a maio de 1991, e por Mário Sérgio Cortella desde a saída de Freire até dezembro de 1992 (CORTELLA, 1992). Trata-se de documento publicado em 1992 pela 
SME-SP e, de acordo com Pernambuco (1994), elaborado em conjunto por esta autora e por representantes dos Núcleos de Ação Educativa e da Diretoria de Orientação Técnica da SME-SP, e baseado nas teses de doutoramento de Angotti (1991), Delizoicov (1991) e Zanetic (1989), bem como em Delizoicov e Angotti (1990). Afirma o referido documento:

\begin{abstract}
"Embora a maioria da população faça uso e conviva com incontáveis produtos do conhecimento tecnológico e científico, os indivíduos pouco refletem sobre esses produtos e os processos envolvidos na sua produção e distribuição, tornando-se, assim, indivíduos sem informação, sem autonomia de opções e sem questionamentos, subordinando-se às regras de mercado, à mídia e ao sabor de interesses alheios. Acostumam-se aos modelos explicativos de sua realidade sem questioná-los. O conhecimento do senso comum (modelo explicativo que o indivíduo tem para um fato ou fenômeno) não lhes permite transpor a visão imediatista e sincrética da realidade.
\end{abstract}

“A mera transmissão e reprodução enciclopedista da Ciência não leva o indivíduo a transcender o senso comum, que continua assim, persistindo como seu instrumento mais forte de captação e ação junto à realidade.

"Tanto o senso comum quanto o pensamento científico são históricos e coletivos. A grande diferença é que a maior articulação explícita do pensamento científico faz com [que] o seu caráter processual, de revisão constante, seja mais intenso. O senso comum, mais diretamente ligado à prática, menos articulado teoricamente, apesar de resolver de imediato algumas questões, tem mais dificuldade em extrapolar as soluções, enxergar os contextos, de ser transmitido em linguagem escrita (muitas vezes até em linguagem oral, sendo transmitido somente por ações) e por isso mesmo sofre transformações mais lentas, não dando conta das mudanças que estão ocorrendo. À medida que ambos falam da realidade imediata na qual os indivíduos estão inseridos, através do diálogo, é possível levá-los a apreender e apropriar-se dos conhecimentos científicos através de uma problematização do seu senso comum, dando-lhes a oportunidade de transitar entre os dois conhecimentos, usando-os quando e onde forem necessários.

"Introduzir o conhecimento científico sem considerar o senso comum leva os indivíduos a decorarem simplesmente o novo conhecimento e continuar a pensar e a agir somente a partir do senso comum. Contemplar a realidade somente a partir do senso comum nega aos indivíduos a oportunidade de acesso à maneira de pensar que tem sido base para a construção da sociedade contemporânea." (SÃO PAULO ${ }^{11}$, 1992, apud PERNAMBUCO, 1994, p.40-41)

Assim, percebemos que Pernambuco (1994) se coloca contra a pedagogia enciclopédica, em que a Ciência é transmitida e não estudada, em que ela é reproduzida e não reconstruída. Sua justificativa é a de que a Ciência não se fixa ao raciocínio do indivíduo enquanto não simula o senso comum no sentido de ligar-se à prática e de estar presente no cotidiano do aluno. Pernambuco busca uma educação que contempla o movimento e a mudança, que entende como indissociáveis "ensino e aprendizagem, ciência e cultura, e, como consequência, metodologias e conteúdos escolares" (p.105) e, ainda, que considera:

${ }^{11}$ SÃO PAULO (Município). Secretaria Municipal de Educação. Visões de área: coleção de autores coletivos. v.5. São Paulo: SME-SP, 1992. 
- $\quad$ que aprendizagem e ensino se dá nas ações que o sujeito estabelece sobre um e em um meio;

- como sujeito o educando, compreendido nas suas dimensões afetiva, corporal e cognitiva, nas relações que estabelece em situações de aprendizagem. Sujeito este, coletivo (grupos de educandos) e ontológico (imerso em relações que lhe dão significado existencial), em constante processo de modificação;

- o meio como o propiciador das oportunidades de ação ao sujeito: tanto o deliberadamente organizado para possibilitar a aprendizagem, com destaque para a escola, como o não deliberadamente organizado, as situações não formais;

- as ações como oportunidade de mudanças específicas, à medida que internalizadas pelos sujeitos, individuais e coletivos, portanto ligadas às significações e aos desafios que propõem;

- a ciência como parte da cultura, com características próprias, em especial o seu poder e a sua história de produção não linear, construída coletivamente em um processo de intercâmbio e de constante revisão, que, no campo epistemológico, delimita recortes e formas de atuação específicos;

- finalmente, que as ações geradas para o aprendizado das ciências estão ligadas a uma compreensão do campo epistemológico que as delimita (PERNAMBUCO, 1994, p.105-6).

Pernambuco (1994) propõe, também, uma ação coletiva permanente, que revê e reelabora continuamente a forma de trabalho para viabilizar a apropriação e a construção de novos conhecimentos sobre o processo pedagógico. Este tipo de intervenção se assemelha à interação característica de pesquisa participante, como a que proponho nesta tese, ou mesmo à pesquisa-ação. No entanto, esta proposta de contínua mudança merece ser levada com cautela. Pernambuco (1994) lembra que, ainda que uma prática seja percebida por um grupo como insatisfatória, ela está, na grande maioria dos casos, enraizada nos sujeitos que a fazem. Daí a importância da existência de um fator desequilibrante, um fator de ruptura com a mentalidade anterior, para que a mudança possa ocorrer. Segundo a autora, são necessários alguns fatores para que os envolvidos possam participar da mudança: estímulos diretos; sentimento de participação real; disponibilidade de tempo; disponibilidade de material; remuneração estável e digna, entre outros. Em relação ao processo em si, seriam fatores indispensáveis: avaliação constante; pesquisa permanente; diretrizes básicas e propostas alternativas; consensos intermediários permanentemente revistos e confrontados com os resultados das avaliações.

Pernambuco (1994) tem a consciência de que o fundamento da mudança é o diálogo, e que todos os envolvidos precisam ter liberdade e autonomia para propor, trabalhar, elaborar, sugerir, avaliar, conhecer, desencadear processos partilhados etc., articulando formação contínua com gestão democrática e participativa. Sabe, também, que, ao menos parcialmente, a gestão financeira do ambiente de trabalho precisa de autonomia, para que as decisões coletivas possam ser implantadas no âmbito da gestão do grupo. Além disso, é desejável que o 
grupo possa se manter pouco sujeito às constantes flutuações advindas de mudanças na gestão política, possibilitando a continuidade das mudanças iniciadas pelo próprio grupo.

Por fim, Pernambuco (1994) destaca dois pontos importantes a permear sua proposta: o compromisso com uma posição política e com as relações afetivas presentes em uma interação educacional. A obra de Paulo Freire e, em particular, o recorte que se fez desse pensamento em seções anteriores desta tese revelam uma forma de se lidar com estas questões, que estão intimamente ligadas e são indissociáveis. Em relação ao compromisso político, a autora lembra que este não deve se manter no campo do discurso, mas precisa ter consequências práticas. Esta defesa da posição política não deve, no entanto, impossibilitar a negociação, a transição, a mudança. Afinal, lembra a pesquisadora, na negociação política em que as relações afetivas positivas são consideradas, estão presentes o “entusiasmo, o 'elan', o desafio, o apoio, ao lado da tolerância, da paciência, do respeito aos limites e às idiossincrasias alheias e institucionais" (p.145), e é essa ação conjunta que gera os espaços de solidariedade onde podem se estabelecer as relações de cooperação, sobrepujando relações de subordinação.

Outros autores relacionam a formação de professores de ciências à dialogicidade. Para Dotta e Giordan (2007), as possibilidades de interação geradas pelas TIC dependem de estratégias didáticas que promovam o diálogo problematizador. Para Motta e Angotti (2011), também as ferramentas computacionais projetadas para a EaD precisam estar alicerçadas em uma pedagogia voltada à busca pela autonomia do aluno. Souza, de Bastos e Angotti (2005) reconhecem que, frequentemente, os alunos têm a expectativa de receber tudo pronto do professor, aguardam que o docente se esforce por eles, e que permita a eles manter-se em situação passiva. Daí, para Motta e Angotti (2011), é preciso equilibrar as forças entre professor e aluno na EaD: para que o aluno persiga a autonomia, antes evidenciada, o professor precisa buscar estratégias para que isto possa acontecer. Assim, para Souza, de Bastos e Angotti (2005), é basilar que se respeite o aluno e sua palavra, o que só acontece quando o professor aguarda, comparte, abre-se para o diálogo.

Alonso (2010) também complementa os referenciais trazidos até aqui. A autora entende que como a aprendizagem requer processos coletivos ou "coletivizados" para ser socialmente validada, no sentido de que ideias e conceitos sejam confrontados, é importante que a EaD preocupe-se mais com as formas de convivência dos sujeitos do que com a instrumentalização de seus sistemas como uma das condições da formação. Com isso, os itens básicos de um sistema de $\mathrm{EaD}$ deveriam integrar funcionalidades a perspectivas de diálogo e de convivências, sem abandonar, obviamente, as concepções de aprendizagem. Para a autora, 
se isto não é feito, esvazia-se o que é apontado como específico da modalidade, o que equaliza a oferta dos cursos a distância e, em geral, constitui um sistema alheio aos organismos que institucionalizam os processos acadêmicos nas instituições de nível superior.

\subsection{Detalhamento da pesquisa}

Nesta seção, trato dos objetos pesquisados, dos instrumentos de pesquisa utilizados na obtenção dos dados e dos procedimentos adotados na análise qualitativa das informações e dados construídos ou coletados, seja por meio de observação, levantamento documental, questionários ou entrevistas. Inicialmente, busco realizar uma reconstrução detalhada da constituição dos objetos de pesquisa, dos processos de criação, implantação e execução dos projetos, bem como de seus participantes. No capítulo 6, caracterizo a implantação da EaD nas instituições, bem como o projeto pedagógico dos cursos. No capítulo 7 , caracterizo os atores dos cursos pesquisados, tanto em seu perfil institucional, por meio da descrição de suas atividades e atribuições no sistema UAB, como em seu perfil profissional, através da coleta de dados nas entrevistas e nos seus currículos acadêmicos disponíveis pela internet ou pela Plataforma Lattes. No caso da caracterização dos alunos, tomei outro caminho: nos cursos da UFRN, utilizo relatos e produções acadêmicas dos professores entrevistados. Já no caso da UFT, pude fazer uma caracterização mais precisa por meio da aplicação de um questionário estruturado, respondido por meio do ambiente virtual de aprendizagem três meses após a matrícula. Por fim, a interação entre os atores, bem como as características dos cursos em andamento, foram abordadas no capítulo 8.

A pesquisa que se levou a cabo é do tipo qualitativa. Mais especificamente, podemos denominar este tipo de pesquisa como uma etnografia, como definido por Fraenkel e Wallen (2009), pois se trata de investigação em que se pretende documentar a experiência cotidiana, como foi o caso aqui. Fraenkel e Wallen (2009) também definem a observação participante como enfoque presente nos estudos nos quais os pesquisadores efetivamente tomam parte da situação ou do ambiente que observam. Para caracterizar tais ambientes, busquei fontes documentais e realizei entrevistas, estas últimas tomadas no mês de abril de 2011 na UFRN, e entre abril e agosto de 2012 na UFT. Os entrevistados foram informados oralmente antes do início de cada diálogo sobre os fins para os quais as entrevistas foram realizadas, sendo imediatamente sanadas todas as dúvidas. Alguns entrevistados só puderam ser contatados por e-mail, e o esclarecimento respectivo sobre a finalidade da conversa também foi feito a estes. 
Nesta pesquisa, visando garantir uma confiabilidade ainda maior dos dados obtidos, decidi realizar as entrevistas, quando realizadas pessoalmente ou por telefone, sem gravação de áudio. As conversas foram feitas de forma mais leve, em ambiente e horário escolhidos pelo entrevistado, com coleta de notas apenas por escrito. A partir destas notas, as informações fornecidas foram reconstituídas em um texto, o qual foi submetido aos entrevistados para sua validação.

Os textos intermediários que reuniram as impressões e ideias de todas as entrevistas de cada uma das universidades foram enviados por e-mail, sendo que cada entrevistado recebeu o texto referente ao retrato da sua universidade, incluindo, portanto, o conteúdo extraído das entrevistas com seus colegas. $\mathrm{O}$ objetivo era o de que cada um dos entrevistados tivesse a oportunidade de fazer livremente as correções, exclusões ou inclusões que achassem necessárias. Nem todos os entrevistados fizeram correções. Estes textos finais, já com as correções sugeridas pelos entrevistados, passei a utilizar como referência, além dos demais documentos relacionados aos cursos e, no caso da UFT, das impressões pessoais minhas, nos acontecimentos que também vivenciei. Procedendo desta forma, obtive não somente uma forma digitalmente registrada do consentimento dos entrevistados, mas também a sua ciência quanto aos resultados obtidos. Houve, ainda, casos em que o entrevistado enviou suas respostas por escrito em forma digital. Neste caso, o registro das respostas já foi considerado suficiente, e não foi dado retorno.

O processo de validação das entrevistas orais é exatamente o que Elliott (2000) considera essencial, porque dá voz de interpretação dos fatos e dos atos a cada sujeito participante, bem como permite a sua autorreflexão. Não costuma ser fácil ter os colegas de trabalho como participantes de uma pesquisa que pode revelar aspectos negativos das práticas profissionais deles. No entanto, sempre tive a consciência, ao longo do trabalho, de que, tão importante quanto o "resultado" da pesquisa como tese de doutorado era o resultado prático de mudanças das ações dos envolvidos. Assim, ainda que alguns dos sujeitos possam ter identificado falhas ou deficiências em sua conduta profissional, o campo de possibilidades de reflexão aberto pela pesquisa e sua metodologia especial, de pleno diálogo, permitiu o crescimento de todos.

Uma das opções consideradas para conduzir a pesquisa foi o método da pesquisa-ação, como definida por Fraenkel e Wallen (2009), Thiollent (2008) e outros. Para Elliott (2000), a pesquisa-ação analisa ações e situações sociais problemáticas, suscetíveis de mudanças e que requerem respostas práticas, em oposição a problemas teóricos comuns em outros tipos de pesquisa. Permite aos envolvidos um aprofundamento da compreensão do problema, o qual 
pode levar a uma reorientação das ações. Tal compreensão ocorre do ponto de vista dos envolvidos, ou seja, alunos, professores e gestores, sendo, portanto, influenciada pelos valores, interesses, decisões e atitudes de cada um. No entanto, esta pesquisa não se caracteriza como uma pesquisa-ação, já que, apenas para citar um exemplo, os cursos da UFRN foram abordados meramente por um estudo de caso pertinente para a ação na UFT. Uma das tarefas do pesquisador quando em ação foi a de facilitar a articulação entre as diversas frentes junto às quais a pesquisa se desenvolveu: as coordenações EaD, em Palmas, e de curso, nas cidades de Palmas (Física) e Gurupi (Química); os polos presenciais, situados em cinco municípios do Tocantins (Palmas, Gurupi, Cristalândia, Ananás e Porto Nacional); e

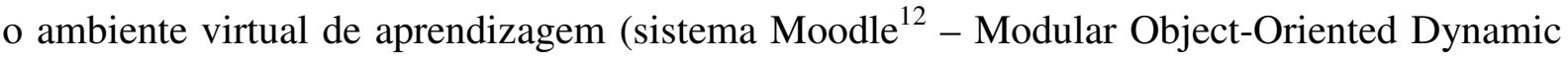
Learning Environment).

Os cursos foram caracterizados a partir das entrevistas realizadas com os professores da UFRN e da UFT. No Rio Grande do Norte, foram entrevistados seis professores gestores da EaD em nível de curso ou em nível de universidade, ligados à Secretaria de Educação a Distância (Sedis) da universidade. O mesmo se deu no Tocantins, onde entrevistei quatro professores gestores. Por razões éticas, não identifiquei os entrevistados nominalmente. Outros dados para a caracterização dos cursos, no caso específico da UFT, foram tomados a partir de atas de reuniões de colegiados de curso, bem como dos polos de apoio presencial. Foram, também, observados alguns encontros presenciais dos cursos tocantinenses.

Posteriormente, sistematizei as representações dos processos administrativos, gerenciais e pedagógicos captadas nas entrevistas, nos documentos e nas respostas dos questionários, buscando destacar as características e os elementos constituintes do sistema de $\mathrm{EaD}$ tais como definidos ou percebidos pelos atores, o que possibilitou uma análise mais ampla dos processos.

Por fim, é preciso lembrar que a área da $\mathrm{EaD}$ já possui referenciais de qualidade oficiais determinados pelo Ministério da Educação em documentos como Referenciais de Qualidade para Educação Superior a Distância (MINISTÉRIO DA EDUCAÇÃO, 2007) e os parâmetros de qualidade para cursos superiores em geral. As recomendações de tais

\footnotetext{
12 O Moodle é o ambiente virtual de ensino e aprendizagem utilizado nos cursos superiores regulares a distância oferecidos pela UFRN e pela UFT. A palavra Moodle é acrônimo da expressão inglesa Modular Object-Oriented Dynamic Learning Environment, significando "ambiente de aprendizagem dinâmico, modular, orientado a objetos", sendo a última expressão, "orientado a objetos", especialmente significativa para programadores. Criado em 1999 pelo australiano Martin Dougiamas, o Moodle tem evoluído desde então, apoiado por uma comunidade global, mantendo a filosofia de uma abordagem social construtivista da educação (DOUGIAMAS, 2010).
} 
documentos não foram desprezadas, embora tenham dirigido mais a ação do pesquisador e de seu grupo do que a análise de tal ação.

Buscar informações não apenas com os líderes dos processos, mas também com os seus usuários, na visão de Thiollent (2008, p.35), mostra que a pesquisa não busca apenas a satisfação própria do pesquisador ou dos líderes. Thiollent complementa a sua argumentação apontando a existência de um "auditório" estruturado em vários níveis, entre eles o do grupo de participantes efetivos da pesquisa, o da população diretamente ligada aos resultados da pesquisa, os setores sociais indiretamente ligados a ela e, por fim, os setores acadêmicos que podem fazer uso dos resultados da pesquisa, criticá-la ou certificá-la. Daí a importância de ouvir o máximo de vozes possível nestes processos. No entanto, sendo muitas das informações obtidas por meio de entrevistas, é preciso relativizar as declarações dos entrevistados, à medida que suas falas incorporaram a passagem do tempo desde a ocorrência dos fatos até o momento da entrevista. No caso do Rio Grande do Norte, isto significa, em algumas passagens, mais de 6 anos. Portanto, interpretei e analisei certas falas sob os referenciais escolhidos com a cautela necessária.

Em suma, as etapas desta pesquisa foram:

- Caracterização dos cursos de licenciatura em Física e em Química da UFT e da UFRN por meio de fontes documentais, questionários e entrevistas;

- Caracterização dos atores do sistema UAB, como alunos, tutores, professores e gestores, bem como de seus perfis nos cursos pesquisados;

- Análise crítica do processo de planejamento, organização e operação dos cursos por meio da construção e coleta de dados no material didático, no projeto pedagógico dos cursos, nas entrevistas, nos questionários e em documentos oficiais;

- Identificação de possíveis ações que possam facilitar o alcance dos objetivos fundamentais do sistema $\mathrm{UAB}$ e sugestões para melhorias na operação de licenciaturas $\mathrm{EaD}$ no contexto de estados da região Norte-Nordeste.

Estas etapas estão de acordo com os objetivos traçados para esta pesquisa, explicitados no capítulo 1 desta tese. Desta forma, passaremos a tratar dos dados específicos dos cursos da UFRN e da UFT, buscando, inicialmente, a caracterização dos ambientes e dos contextos sociais, econômicos e institucionais. 


\section{CONTEXTUALIZAÇÃO INSTITUCIONAL}

\subsection{Os estados do Rio Grande do Norte e do Tocantins}

Os estados do Rio Grande do Norte e do Tocantins têm aspectos geográficos e trajetórias históricas bastante distintas, havendo pouco em comum entre eles. Uma das maiores razões para este descompasso é o fato de o Rio Grande do Norte ser um estado litorâneo, ao contrário do Tocantins. A colonização do estado nordestino, portanto, ocorreu muito antes do estado nortista, além de ser este último uma unidade federativa criada muito mais recentemente.

A área do estado do Rio Grande do Norte é de $52.797 \mathrm{~km}^{2}$. Sua população, de acordo com o Censo Demográfico 2010 do Instituto Brasileiro de Geografia e Estatística (IBGE), é de 3.168.133 habitantes. Limita-se a norte e a leste com o Oceano Atlântico, a sul com a Paraíba e a oeste com o Ceará. Sua cobertura vegetal original é de mangue na faixa litorânea, com pequena faixa de Mata Atlântica no centro e caatinga a oeste, não sendo banhado por rios perenes.

O Rio Grande do Norte representava uma das maiores capitanias do início do período colonial. João de Barros e Aires da Cunha foram os responsáveis por buscar sua colonização, em 1535, o que não resultou em sucesso diante do contínuo ataque francês e da resistência indígena. Somente no fim daquele século XVI os portugueses conseguiram se fixar na região, com a construção do Forte dos Reis Magos e o estabelecimento da vila de Natal (LYRA, 2008; VELLOSO, 2006). Mesmo assim, os holandeses dominaram a região por cerca de 20 anos durante o século XVII (MAIA, 1998). O clima e o solo locais não eram tão favoráveis ao cultivo da cana-de-açúcar, de forma que a região tinha como principal atividade econômica a criação de gado, seguida da exploração de sal. O uso do trabalho indígena em regime de escravidão resultou na reação da nação cariri, que, com outras tribos, deram seguimento à Guerra dos Bárbaros durante quase 20 anos no fim do século XVII (VELLOSO, 2006).

Durante o período do Brasil Colônia, o Rio Grande do Norte se manteve como região pobre e de escasso povoamento. Foi na época imperial que a província começou a explorar mais intensamente o comércio de produtos como o sal e a carne de sol. Ao fim do século 19, instalaram-se as primeiras indústrias têxteis, possíveis graças ao fornecimento de algodão por produtores locais (LYRA, 2008; VELLOSO, 2006). Antes de o movimento da Intentona 
Comunista ser reprimido, ele chegou a dominar a capital Natal, em 1935. Já na Segunda Guerra Mundial, o estado serviu de base para as forças armadas dos Estados Unidos. Apesar do aumento de investimentos proporcionado pela criação da Superintendência de Desenvolvimento do Nordeste, a Sudene, na década de 1960, o crescimento dos setores de exploração mineral, agrícola e industrial foi lento (VELLOSO, 2006).

O Tocantins, estado da região Norte e, portanto, pertencente integralmente à região da Amazônia Legal, possui uma extensão territorial de $277.621 \mathrm{~km}^{2}$ (cerca de $20 \%$ maior que a soma das áreas dos estados do Rio Grande do Norte, da Paraíba, de Pernambuco e de Alagoas). Limita-se a sul com Goiás, a sudoeste com Mato Grosso, a noroeste com o Pará, a nordeste com o Maranhão, a leste com o Piauí e a sudeste com a Bahia. Tem uma população de 1.383.453 habitantes, de acordo com o Censo Demográfico do IBGE, realizado em 2010. Tal população cresceu acima da média nacional durante as décadas de 1990 e 2000, graças a correntes migratórias regionais (VELLOSO, 2006).

A ocupação e o desenvolvimento socioeconômico do Tocantins, o antigo norte goiano, se deveram a variadas razões, cada uma definida e limitada no tempo. Inicialmente, a mineração do ouro de aluvião incentivou uma corrente migratória na região central e sudeste do atual território tocantinense, mais intensamente entre 1730 e 1770 . Com a redução brutal da produção de ouro e a intensificação da cobrança de impostos por parte da Coroa, as elites locais entenderam ser conveniente promover a autonomia da região, visando, também, à abertura de novos espaços políticos. Embora não tivessem obtido a criação de uma nova província desmembrada de Goiás, estas elites conseguiram a criação de uma comarca, com sede na atual cidade de Paranã, no sul do atual Tocantins, em 1815 (PRETTO; PEREIRA, 2008; NASCIMENTO, 2009). Um movimento separatista perdurou por pouco mais de um ano, de 1821 a 1823, criando a província da Palma.

A região permaneceu quase totalmente dominada pelos indígenas no período de 1770 até 1930, durante o qual a economia se baseava quase que exclusivamente na pecuária, alguma agricultura e na navegação pelos rios Araguaia e Tocantins, e dominada pelo mesmo coronelismo que permeava toda a então província de Goiás. Ao longo das décadas de 1930, 1940 e 1950, a região oeste do atual território tocantinense foi ocupado com o objetivo de explorar o recém-descoberto cristal de rocha (quartzo) na região. Novo fluxo migratório foi verificado a partir de 1957, com a construção da rodovia Belém-Brasília. Diversos núcleos urbanos se estabeleceram às margens dessa rodovia, a atual BR-153 (NASCIMENTO, 2009). A criação do estado de Mato Grosso do Sul, em 1977, e um rápido desenvolvimento da região sul do estado de Goiás, em detrimento do norte, favorecem um movimento interno para a 
divisão, incentivado na população pelas lideranças políticas locais (BASTOS, 2010; TOCANTINS, 2012; NASCIMENTO, 2009). Em 1988, com a promulgação da Constituição Federal, é criado o estado do Tocantins. O sentimento de abandono transformou-se em perspectivas de prosperidade econômica. A euforia inicial, no entanto, em nada alterou a precária situação da maioria das pessoas, já que se resumiu à implantação de incipientes propostas de políticas públicas (PRETTO; PEREIRA, 2008).

As economias dos dois estados estudados também é bastante diferente. A economia potiguar tem como pilares o comércio, a indústria têxtil, a agroindústria e o turismo. É o maior produtor de petróleo extraído em terra no Brasil. Além disso, produz $90 \%$ do sal marinho nacional, graças às condições climáticas de poucas chuvas, temperatura sempre elevada e ventos secos. Já o Tocantins, atravessado ao meio no sentido sul-norte pelo rio Tocantins e em sua fronteira oeste, no mesmo sentido, pelo rio Araguaia, tem na pecuária a principal atividade produtiva. A cultura da soja é crescente e se junta a outras, como a do arroz, da mandioca, da cana-de-açúcar e do milho. A exploração mineral também tem crescido. Obra importante vem sendo conduzida no território tocantinense: a ferrovia Norte-Sul, paralela à rodovia BR-153 e ligada ao porto de Itaqui, em São Luís, Maranhão.

\subsection{Educacão nos estados do Rio Grande do Norte e do Tocantins}

De acordo com o Censo Escolar de 2009, o Rio Grande do Norte possui 34.640 professores atuantes. São 13.196 os professores potiguares que só possuem o ensino médio, incluindo o magistério, e 309 completaram somente o ensino Fundamental. Há, ainda, 1.015 professores que possuem ensino Superior, mas não uma formação em Licenciatura. Em suma, apenas 20.077 professores de um total de 34.640 são licenciados, ou 58,0\%. Este número está um tanto abaixo da média nacional, que é de 64,0\% (INSTITUTO..., 2011b).

O mesmo Censo Escolar nos traz a informação de que, no Rio Grande do Norte, 730 professores possuem formação superior em Ciências e 1.047 em Ciências Físicas, em um universo de 21.613 diplomas de ensino Superior: proporção de 8,2\%. Se considerados apenas os professores que atuam no ensino Médio, nível em que a carga horária de Ciências é mais alta, temos 398 diplomas em Ciências e 645 em Ciências Físicas, de um total de 5.286 diplomas: proporção de 19,7\% (INSTITUTO..., 2011b). Um destaque negativo da educação potiguar é a sua taxa de analfabetismo: 20,74\% em 2008, a quinta maior proporção de analfabetos do país (SECRETÁRIO..., 2009). 
De acordo com o Censo Escolar de 2009, 17.583 docentes atuam no estado do Tocantins. São 4.911 os professores tocantinenses que só possuem o ensino médio, incluindo o magistério, e 183 completaram somente o ensino Fundamental. Há, ainda, 775 professores que possuem ensino Superior, mas não uma formação em Licenciatura. Em suma, apenas 11.700 professores de um total de 17.583 são licenciados, ou 66,5\%, número próximo à média nacional de 64,0\% (INSTITUTO..., 2011b).

O mesmo Censo Escolar nos traz a informação de que, no Tocantins, 463 professores possuem formação superior em Ciências e 448 em Ciências Físicas, em um universo de 12.696 diplomas de ensino Superior: proporção de 7,2\%. Se considerados apenas os professores que atuam no ensino Médio, temos 316 diplomas em Ciências e 271 em Ciências Físicas, de um total de 3.713 diplomas: proporção de 15,8\% (INSTITUTO..., 2011b), inferior aos 19,7\% do Rio Grande do Norte. Quando pensamos na proporção esperada de aulas de Ciências em relação à carga horária total do ensino Médio, fica clara a discrepância, ou seja, a falta de professores de Ciências em relação à eventual falta de professores em outras áreas.

Quando da emancipação do estado, este apresentava índices altíssimos de alunos em idade escolar sem acesso à Educação Básica, bem como de professores leigos em exercício (PRETTO; PEREIRA, 2008). Houve, sim, uma melhora grande neste quadro, com um número de professores não licenciados que, apesar de ainda ser grande, é proporcionalmente muito melhor que o número de 1990, ou mesmo o número de 2000, segundo Pinto (2007). Scheibe (2006), no entanto, nos orienta a interpretar o dado com cautela, visto que há, em curso, uma política de certificação, com a proliferação de cursos de reduzida carga horária, os quais se afirmam mais como educação compensatória do que formativa.

O Tocantins, apesar de apresentar aspectos muito particulares em seu panorama educacional, é muito pouco observado sob o ponto de vista acadêmico, ou seja, com produção bibliográfica muito pequena, mas cujas particularidades demandam mais estudos de profundidade. Quanto ao quadro educacional do Estado, é notável o fato de que o Tocantins é o estado da federação que paga um dos mais altos salários para os professores da Educação Básica. E, apesar disso, o Estado possui uma proporção alta de professores leigos ou sem formação na área sobre a qual ministram aulas, especialmente se tratarmos das áreas de Matemática e de Ciências Naturais. Os cursos examinados, como todos os cursos pertencentes ao sistema UAB, pretendem reduzir este déficit na formação dos professores. 


\subsection{As universidades federais do Rio Grande do Norte e do Tocantins}

A origem da UFRN está na estadual Universidade do Rio Grande do Norte, criada em 1958 e instalada em 1959. Tal universidade foi formada a partir de faculdades e instituições de nível superior já existentes em Natal, como a Faculdade de Farmácia e Odontologia, a Faculdade de Medicina, a Escola de Engenharia, a Faculdade de Direito e outras. Esta instituição foi federalizada em 1960. A reforma universitária de 1968 reorganizou internamente a UFRN, extinguindo as faculdades e consolidando a estrutura atual, de departamentos agrupados em centros acadêmicos. Na década de 1970, deu-se início à construção do campus central, em uma área de $1,23 \mathrm{~km}^{2}$. Atualmente, o campus se encontra integrado à malha urbana da cidade de Natal, sendo dotado de diversos setores de salas de aula, laboratórios e bibliotecas, restaurantes, agências bancárias, livrarias, e galeria de arte.

No início de 2011, a UFRN oferecia 75 cursos de graduação presencial e 73 cursos de pós-graduação stricto sensu, sendo sua comunidade acadêmica formada por mais de 28.000 estudantes de graduação e de pós-graduação, além de cerca de 1.700 docentes. Os principais eventos solenes da UFRN costumam ocorrer na Praça Cívica, projetada como um grande anfiteatro ao ar livre. É onde também foi instalada a Secretaria de Educação a Distância (Sedis) da universidade, a qual foi criada em junho de 2003.

Segundo vídeo institucional da Sedis, produzido em 2009 e disponível em fevereiro de 2011 em sua página de internet, o primeiro ingresso de alunos na EaD da UFRN ocorreu em 2005, nas licenciaturas em Física, Química e Matemática. Ainda segundo o vídeo, envolvem-se com a EaD no âmbito da UFRN 150 docentes e mais de 50 funcionários para o apoio técnico. A Sedis dispõe de estrutura plena para a produção audiovisual, com estúdio para a gravação de videoaulas, por exemplo. Em 2009, já eram sete as graduações ofertadas pela UFRN: além das licenciaturas citadas, já havia oferta de licenciaturas em Geografia, Ciências Biológicas e bacharelados em Administração e em Administração Pública, em um total de 4.000 alunos, tendo naquele ano, 80 alunos já formados pelos primeiros três cursos implantados. O ingresso nos cursos de graduação a distância da UFRN é feito exclusivamente através de vestibular realizado pela própria universidade. Foram realizados cinco concursos vestibulares para ingresso nos cursos pesquisados até 2011: um em 2005, dois em 2007, um em 2009 e outro em 2010.

A Fundação Universidade Federal do Tocantins (UFT) foi criada em 2000, embora somente em 2003 tenham sido iniciadas suas atividades acadêmicas, com a posse dos 
primeiros professores concursados e a efetiva transferência de patrimônio da Unitins para a fundação federal. Segundo a página da instituição na internet, a UFT tem como sua maior missão tornar-se um polo diferencial na educação e no desenvolvimento de pesquisas e projetos integrados ao contexto socioeconômico e cultural do estado do Tocantins. Ao incorporar alguns dos campi da Unitins, a UFT se constituiu sob uma estrutura multicampi, presente em sete municípios do estado: Araguaína, Arraias, Gurupi, Miracema do Tocantins, Palmas, Porto Nacional e Tocantinópolis. Em 2010, eram mais de 650 docentes e 9 mil alunos para 43 cursos presenciais de graduação e dez de pós-graduação stricto sensu.

A divisão interna da UFT dedicada a cuidar da EaD começou a ser discutida em 2004 no âmbito da vice-reitoria. A então vice-reitora, mesmo após deixar o cargo em agosto de 2008, seguiu à frente da EaD na UFT, agora como coordenadora do Centro de Novas Tecnologias Educacionais (CNTE), nome mudado para Centro de Tecnologias Educacionais (CTE) em dezembro de 2009 e para Diretoria de Tecnologias Educacionais (DTE) em fevereiro de 2011. O curso de licenciatura em Ciências Biológicas a distância, ofertado nos campi de Araguaína, Arraias, Gurupi e Porto Nacional, foi o primeiro passo concreto dado para a implantação da EaD na UFT. Em nível de pós-graduação lato sensu, a UFT já ofertava, em 2007, o curso de especialização em Gestão Escolar, do Programa Escola de Gestores da Educação Básica do MEC, e, no início de 2010, passou a oferecer os cursos do Programa Nacional de Formação em Administração Pública (PNAP), que são especializações em Gestão Pública, Gestão Pública Municipal e Gestão em Saúde. Além dos cursos de Licenciatura em Física e em Química, iniciados em outubro de 2010 com materiais didáticos produzidos pela UFRN, já está sendo discutida e analisada a criação de novos cursos na modalidade EaD, como uma Licenciatura em Matemática, também com a utilização dos materiais da UFRN, mas sem o referencial freireano.

\subsection{Os polos UAB da UFRN e da UFT}

Nesta seção, caracterizo os municípios cujos polos dos programas Pró-Licenciatura e UAB receberam alunos das licenciaturas da UFRN. A localização destes municípios pode ser vista na Figura 1, no mapa dos estados do Rio Grande do Norte, Paraíba, Pernambuco e Alagoas.

Os polos situados nas cidades de Nova Cruz, Macau e Currais Novos foram constituídos como resposta ao edital do programa Pró-Licenciatura. Os terrenos e parte dos 
edifícios em que se situam já constituíam patrimônio da UFRN, que possuía, na década de 1970 e 1980, como base para a formação de professores, campi avançados nestas cidades (CENTRO DE ENSINO SUPERIOR DO SERIDÓ, 2002), bem como na cidade de Caicó (cujo polo não oferta os cursos aqui estudados). Possuem, atualmente, uma jurisdição rara em todo o sistema UAB: trata-se de quatro polos cujo mantenedor é federal, e cujos coordenadores são professores ativos ou aposentados da universidade federal local. Trata-se, também, dos únicos polos que tiveram ingresso de alunos em todas as seleções da UFRN.

Tabela 1 - Caracterização dos municípios com vagas para os cursos de Física e de Química da UFRN

\begin{tabular}{lrr|r|r|r|r|}
\hline \multicolumn{1}{c|}{ Município } & População & DEF & DEM & EEF & EEM & $\begin{array}{c}\text { Distância até } \\
\text { a sede (Natal) }\end{array}$ \\
\hline Nova Cruz (RN) & 35.541 & 356 & 105 & 45 & 5 & $101 \mathrm{~km}$ \\
Macau (RN) & 28.974 & 225 & 59 & 26 & 3 & $181 \mathrm{~km}$ \\
Currais Novos (RN) & 42.668 & 379 & 160 & 35 & 10 & $182 \mathrm{~km}$ \\
Campina Grande (PB) & 385.276 & 3.121 & 1.138 & 295 & 54 & $239 \mathrm{~km}$ \\
Tabira (PE) & 26.430 & 241 & 80 & 27 & 4 & $422 \mathrm{~km}$ \\
Nazaré da Mata (PE) & 30.782 & 261 & 112 & 32 & 6 & $244 \mathrm{~km}$ \\
Petrolina (PE) & 294.081 & 2.522 & 1.035 & 217 & 51 & $897 \mathrm{~km}$ \\
Garanhuns (PE) & 129.392 & 995 & 351 & 122 & 21 & $480 \mathrm{~km}$ \\
Surubim (PE) & 58.444 & 480 & 176 & 56 & 6 & $303 \mathrm{~km}$ \\
Maceió (AL) & 932.608 & 5.793 & 2.055 & 325 & 116 & $538 \mathrm{~km}$ \\
Luís Gomes (RN) & 9.612 & 117 & 30 & 14 & 2 & $447 \mathrm{~km}$ \\
Martins (RN) & 8.228 & 89 & 20 & 17 & 2 & $359 \mathrm{~km}$ \\
Extremoz (RN) & 24.550 & 230 & 58 & 32 & 3 & $21 \mathrm{~km}$ \\
TOTAL & 2.006 .586 & 14.809 & 5.379 & 1.243 & 283 & - \\
\hline
\end{tabular}

Legenda: População: censo do IBGE de 2010; DEF: docentes de ensino Fundamental; DEM: docentes de ensino Médio; EEF: escolas de ensino Fundamental; EEM: escolas de ensino Médio (fonte de DEF, DEM, EEF e EEM: Inep/MEC).

Os polos de Campina Grande, Maceió, Garanhuns e Petrolina foram atribuídos aos cursos da UFRN em virtude do consórcio formado entre a UFRN, a Universidade Estadual da Paraíba (UEPB), a Universidade de Pernambuco (UPE) e a Universidade Federal de Alagoas (Ufal). O edital Pró-Licenciatura exigia a constituição de consórcios interuniversitários, e a UFRN se associou às universidades citadas. Como os editais do sistema UAB não exigem a 
constituição de consórcios, tais polos não recebem, desde 2007, novas turmas de alunos nos cursos da UFRN.

Em Nazaré da Mata, Tabira e Surubim, no estado de Pernambuco, situam-se polos constituídos pelo governo estadual e mantidos pelas prefeituras municipais, visando à formação de professores. A Universidade de Pernambuco aproveitou a estrutura existente para atribuir os cursos do consórcio a estes municípios. Assim como os demais polos localizados fora do estado do Rio Grande do Norte, Tabira e Surubim não recebem novos alunos da UFRN desde 2007.

Os polos de Martins, Luís Gomes e Extremoz foram constituídos mais recentemente, já dentro do sistema UAB. São polos municipais, todos no estado do Rio Grande do Norte, ainda em fase de consolidação. Só receberam ingresso de alunos da UFRN a partir de 2009.

A tabela 1 traz características dos municípios que abrigam os polos onde são ofertados os cursos de Física e de Química EaD da UFRN. Todos eles recebem o curso de Física. O curso de Química é ofertado em 4 polos a menos: apenas Garanhuns recebe o curso em Pernambuco.

A seguir, estão caracterizados os municípios cujos polos da UAB receberam alunos das licenciaturas da UFT. A caracterização se completa com as tabelas 2 e 3. A localização destes municípios pode ser vista na Figura 2, que traz um mapa do estado do Tocantins. 


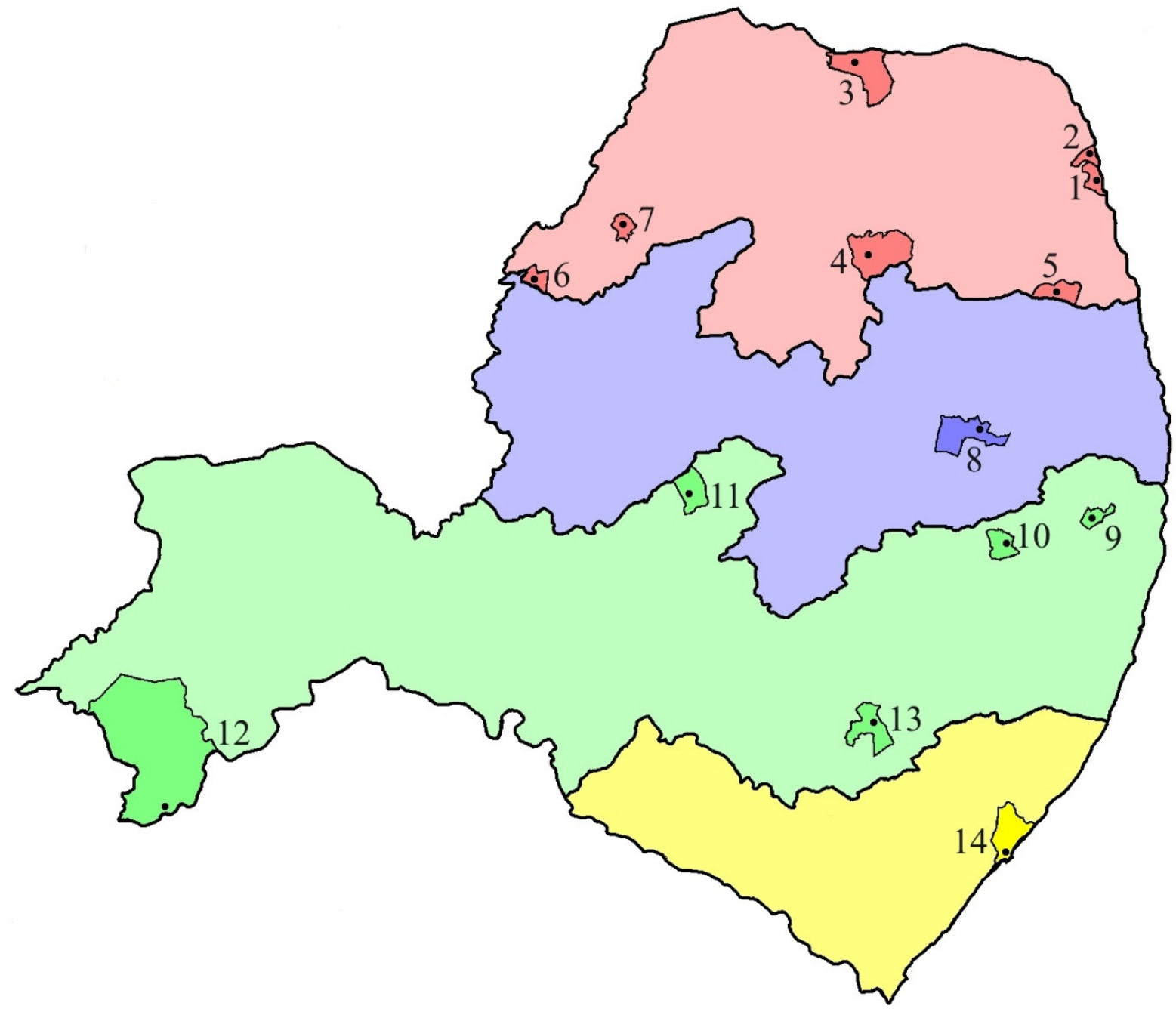

Legenda: 1 - Natal; 2 - Extremoz; 3 - Macau; 4 - Currais Novos; 5 - Nova Cruz; 6 - Luís Gomes; 7 - Martins; 8 - Campina Grande; 9 - Nazaré da Mata; 10 - Surubim; 11 - Tabira; 12 - Petrolina; 13 - Garanhuns; 14 - Maceió.

Figura 1 - Mapa dos estados do Rio Grande do Norte, Paraíba, Pernambuco e Alagoas com a identificação dos municípios que possuem polos

Palmas é uma cidade projetada para ser a capital do estado do Tocantins. Compreende não somente a área do Plano Diretor, mas também a populosa região periférica dos setores Aureny, seu vizinho distrito de Taquaralto (ambos afastados mais de $15 \mathrm{~km}$ do centro do Plano Diretor e não conurbados com o mesmo) e o pequeno distrito de Taquaruçu (a mais de $30 \mathrm{~km}$ ). Nestas pouco mais de duas décadas de construção, Palmas já se transformou na cidade mais populosa do Estado, ainda que siga sendo a menor capital estadual do Brasil. Sua economia é fortemente baseada no setor público, embora os setores de comércio, serviços e turismo tenham tido visível crescimento nos últimos anos. Em 2011, possuía dez instituições de ensino superior, com mais de 60 cursos de graduação presenciais. $\mathrm{O}$ polo de educação a 
distância de Palmas é mantido pelo governo estadual. Além do curso de licenciatura em Física da UFT, o polo possui as graduações em Administração (bacharelado), Artes Visuais (licenciatura) e Teatro (licenciatura), todos pela UnB, Pedagogia e Letras (licenciaturas) pela UAB/Unitins e Agricultura Familiar e Sustentabilidade (tecnológico) pela Universidade Federal de Santa Maria (UFSM).

A cidade de Gurupi, distante $222 \mathrm{~km}$ de Palmas, nasceu como um acampamento dos operários da construção da rodovia Belém-Brasília, no fim da década de 1950. Hoje, a cidade é a terceira maior do Estado. Viveu uma estagnação na década de 1990, por conta da intensa migração para a capital recém-construída. Sua economia está fortemente ligada ao setor agrário, especialmente à criação de gado bovino, à plantação de soja e arroz, e ao setor de serviços ligados ao setor primário. Gurupi possui 20 cursos presenciais em três instituições. Seu polo de educação a distância encontra-se provisoriamente instalado no campus da UFT, possuindo outro curso de graduação além do curso de Química: o de licenciatura em Biologia, também ofertado pela UFT.

A cidade de Porto Nacional tem suas origens na primeira metade do século XVIII, com a corrida ao ouro de aluvião no então norte goiano. O ouro extraído no sudeste e leste do atual Tocantins, na região das atuais Monte do Carmo e Dianópolis, era embarcado no porto existente na então cidade de Porto Real. Viveu uma fase de aguda estagnação durante séculos, embora seguisse operando o seu porto fluvial e fosse um núcleo urbano culturalmente ativo na região. Porto Nacional, hoje a quarta maior cidade do estado em população, tem a economia baseada na agropecuária, com diversas indústrias diretamente ligadas ao setor, como as plantas de produção de biodiesel e de fertilizantes. Porto Nacional oferece dez cursos de graduação presenciais em três instituições. O polo de educação a distância de Porto Nacional é mantido pela prefeitura. Além do curso de licenciatura em Química da UFT, o polo possui as graduações em Educação Física (licenciatura) e Música (licenciatura), ambos pela UnB.

As histórias de Cristalândia e de Ananás remetem às décadas de 1930 e 1940, quando foram descobertas ao longo da região oeste do estado algumas reservas naturais de cristal de rocha (quartzo). Embora o movimento migratório para a exploração mineral tenha sido curto, ele levou à criação de nove cidades na região (NASCIMENTO, 2009). Hoje, Cristalândia e Ananás veem o predomínio do setor agropecuário em suas atividades econômicas, bem como o setor de serviços ligados à agropecuária. Não há ensino superior presencial nesses municípios. Seus polos de educação a distância funcionam em instalações municipais. Cristalândia abriga três licenciaturas ofertadas pela UFT: além dos cursos de Física e de Química, também oferta o de Biologia. A Unitins também oferta seus dois cursos UAB em 
Cristalândia. Ananás, além do curso de licenciatura em Física da UFT, oferece as graduações em Computação (licenciatura) pela Universidade Federal Rural de Pernambuco (UFRPE) e Biologia (licenciatura) pela UFT.

De acordo com o edital 99 da UFT, lançado para o vestibular de 2010, mas anulado dias depois, os municípios de Araguacema, Araguatins, Campos Lindos, Dianópolis, Mateiros, Nova Olinda e Wanderlândia também deveriam receber os cursos de Química e os municípios de Araguatins, Dianópolis, Porto Nacional e Mateiros, os cursos de Física. Um edital corrigido, de número 106, fazia constar a seleção para apenas três polos para o curso de Química, Cristalândia, Gurupi e Porto Nacional, e três para o curso de Física, Ananás, Cristalândia e Palmas.

Tabela 2 - Caracterização dos municípios com vagas para o curso de Física UFT

\begin{tabular}{l|r|r|r|r|r|r|r}
\hline \multicolumn{1}{c|}{ Município } & População & DEF & DEM & EEF & EEM & $\begin{array}{c}\text { Distância até a } \\
\text { sede (Palmas) }\end{array}$ & Vagas \\
\hline Palmas & 228.297 & 1.536 & 644 & 89 & 29 & - & 25 \\
Cristalândia & 7.218 & 72 & 18 & 5 & 1 & $143 \mathrm{~km}$ & 25 \\
Ananás & 9.873 & 98 & 20 & 13 & 2 & $504 \mathrm{~km}$ & 25 \\
TOTAL & 245.388 & 1.706 & 682 & 107 & 32 & - & 75 \\
\hline
\end{tabular}

Legenda: População: censo do IBGE de 2010; DEF: docentes de ensino Fundamental; DEM: docentes de ensino Médio; EEF: escolas de ensino Fundamental; EEM: escolas de ensino Médio (fonte de DEF, DEM, EEF e EEM: Inep/MEC).

Tabela 3 - Caracterização dos municípios com vagas para o curso de Química UFT

\begin{tabular}{l|r|r|r|r|r|r|r}
\hline \multicolumn{1}{c|}{ Município } & População & DEF & DEM & EEF & EEM & $\begin{array}{c}\text { Distância até a } \\
\text { sede (Gurupi) }\end{array}$ & Vagas \\
\hline Gurupi & 76.765 & 587 & 156 & 47 & 8 & - & 25 \\
Cristalândia & 7.218 & 72 & 18 & 5 & 1 & $165 \mathrm{~km}$ & 25 \\
Porto Nacional & 49.143 & 433 & 152 & 46 & 10 & $154 \mathrm{~km}$ & 25 \\
TOTAL & 133.126 & 1.092 & 326 & 98 & 19 & - & 75 \\
\hline
\end{tabular}

Legenda: População: censo do IBGE de 2010; DEF: docentes de ensino Fundamental; DEM: docentes de ensino Médio; EEF: escolas de ensino Fundamental; EEM: escolas de ensino Médio (fonte de DEF, DEM, EEF e EEM: Inep/MEC). 


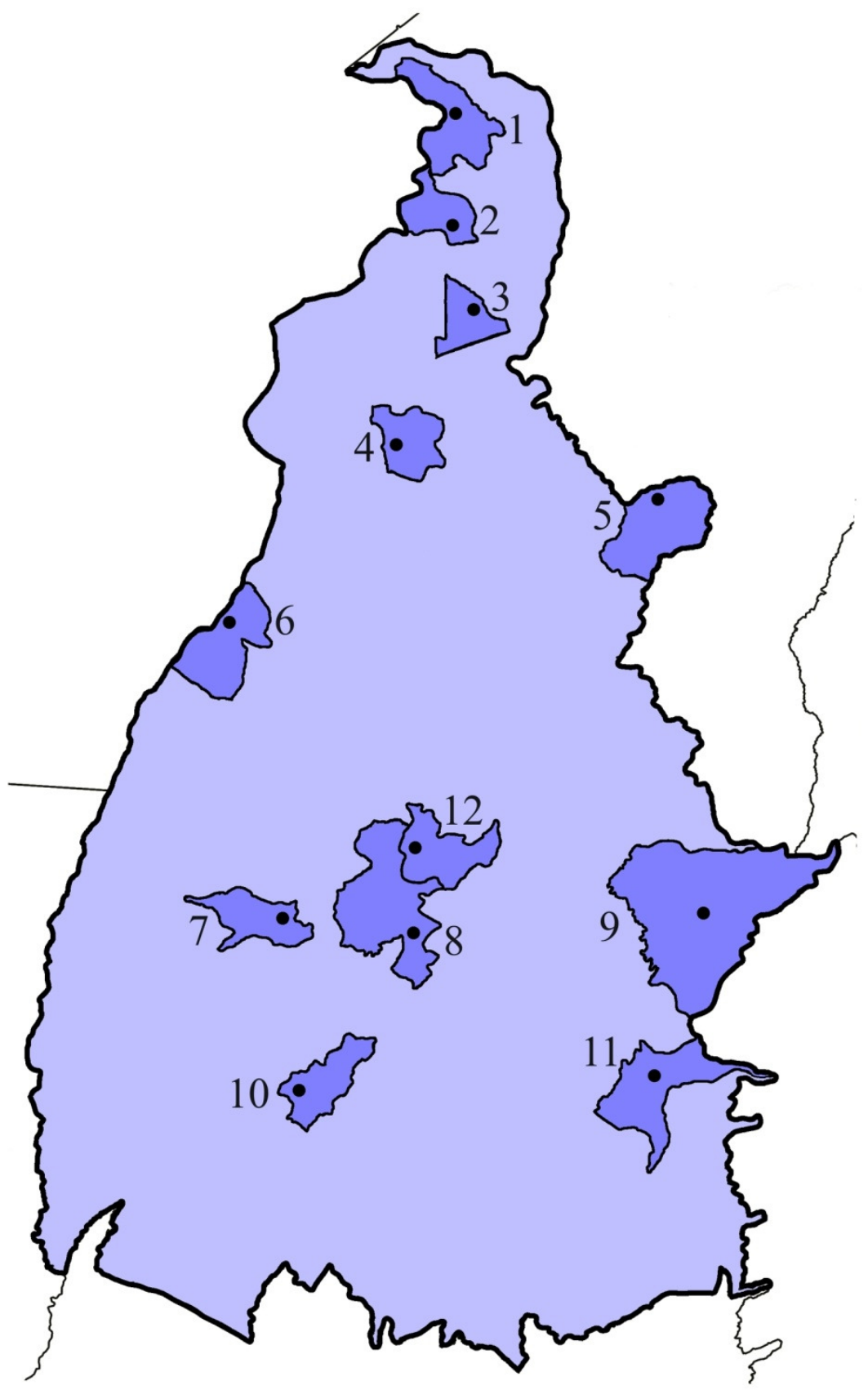

Legenda: 1 - Araguatins; 2 - Ananás; 3 - Wanderlândia; 4 - Nova Olinda; 5 - Campos Lindos; 6 - Araguacema; 7 - Cristalândia; 8 - Porto Nacional; 9 - Mateiros; 10 - Gurupi; 11 - Dianópolis; 12 - Palmas.

Figura 2 - Mapa do estado do Tocantins com a identificação dos municípios que possuem polos UAB 


\section{CURSOS EM FOCO: CONSTRUÇÃO DO ROTEIRO}

A partir deste ponto, realizo a reconstrução do processo de criação, implantação e funcionamento dos cursos de licenciatura em Física e Química de ambas as universidades a partir dos depoimentos dos professores e ex-professores gestores de ambos os cursos e gestores da $\mathrm{EaD}$ nas instituições, bem como de outros atores envolvidos. Os nomes dos depoentes foram retirados, diante do entendimento de que não seria ético mantê-los e divulgá-los publicamente. Os entrevistados, assim, passam a ser conhecidos por letras, indistintamente quanto à universidade à qual são ligados.

O processo pelo qual os cursos foram construídos se assemelha à da construção de uma peça teatral, em que um texto inicial (roteiro) é adaptado pelos atores e diretores (personagens), que também fazem, com outros profissionais, ajustes em elementos obrigatórios (figurinos, cenários, atos). Assim, se constrói a ação. No caso, temos duas leituras distintas de um mesmo roteiro: os projetos pedagógicos dos cursos (PPC) são quase comuns, bem como seus materiais didáticos. É a análise deste conjunto que farei neste e nos próximos dois capítulos.

\section{1. $\quad$ o processo de criacão institucional da EaD e dos cursos}

O processo de implantação dos cursos de licenciatura em Física e em Química na UFRN se iniciou por volta de 2003. A iniciativa de se implantar a EaD na UFRN surgiu do próprio reitor à época, que teria convivido mais proximamente com a educação a distância durante o seu pós-doutorado nos Estados Unidos. Aquela era, também, uma época de implantação da EaD no Brasil, após a criação da UniRede, consórcio do qual a UFRN fazia parte.

Alguns professores se envolveram na liderança do processo de estruturação da EaD na UFRN, após a criação da Secretaria de Educação a Distância da UFRN, a Sedis, com status de pró-reitoria. Havia, inicialmente, um coordenador $\mathrm{EaD}$, uma assessora pedagógica (a professora Marta Pernambuco) e um coordenador de projetos. Por meio de convites, foram levantados, junto aos departamentos de Física, Química, Matemática, Educação e outros, professores que se interessavam por iniciar um trabalho na EaD. 
O edital do programa Pró-Licenciatura, lançado pela Seed, foi o caminho utilizado pela UFRN para financiar a EaD. Tal edital, referente à Chamada Pública MEC/Seed 01/2004, exigia que as instituições públicas de ensino superior estivessem organizadas em consórcios ou em instituições que os representassem. Desta forma, a UFRN se uniu à UPE, à UEPB e à Ufal, possivelmente visando a atingir um número mais alto de estados atendidos, já que este era um dos critérios de pontuação da chamada pública.

O processo de implantação do consórcio foi liderado pela UFRN, que já estava mais adiantada em seus projetos de criação de cursos na modalidade EaD. A UFRN se inspirou em projetos que já estavam em andamento no país, como o do consórcio Cederj e o da UFSC, que obteve autorização para iniciar a oferta de cursos em EaD ainda em 2003, por meio da portaria MEC 1063, de 8 de maio de 2003. A UFRN se beneficiou do fato de os primeiros editais de chamada para a implantação de cursos na modalidade $\mathrm{EaD}$ preverem verbas maiores. Além de poder estruturar melhor a Sedis, isto possibilitou, também, a implantação de mais cursos em um número maior de polos.

Os projetos pedagógicos e os materiais didáticos dos cursos de Física, Química e Matemática ficaram sob a responsabilidade da UFRN. Tais cursos eram verdadeiramente pioneiros no Brasil: o curso de Física teria sido o terceiro a ser implantado no Brasil, sucedendo apenas aos cursos do consórcio Cederj e da UFSC, enquanto o curso de Química seria o primeiro curso de licenciatura em Química EaD no Brasil ${ }^{13}$, de acordo com o entrevistado D. Teria havido um desafio especial em relação à criação do curso de Química $\mathrm{EaD}$, já que este, por ter alta carga horária prática, especialmente em laboratório, tornava-se especialmente caro, segundo o entrevistado $\mathrm{M}$.

Entretanto, dado o ineditismo da proposta, nem sempre os grupos selecionados no início para estruturar individualmente cada curso operaram a contento. Ainda assim, à época das entrevistas (abril de 2011), eram apenas 14 os professores do departamento de Química, por exemplo, de um total de 49, trabalhando nos cursos da Sedis, de acordo com o entrevistado M.

Na UFT, o processo da implantação da EaD se inicia com a adesão da universidade ao Consórcio Setentrional, liderado pela UnB, para a oferta de uma licenciatura em Biologia, também no âmbito do programa Pró-Licenciatura. Tal curso teve início em 2007 e formou

\footnotetext{
${ }^{13}$ A Universidade Federal do Ceará (UFC) recebeu da Câmara de Educação Superior do Conselho Nacional de Educação parecer favorável para o credenciamento, por cinco anos, de cursos de licenciatura em Matemática, Física, Química e Biologia muito antes da UFRN, ainda em 1998 (Parecer CNE/CES 887/98, de 2 de dezembro de 1998). No entanto, não houve portaria do MEC que autorizasse o funcionamento de tais cursos, e a UFC só veio a iniciar a oferta de licenciaturas a distância nas referidas áreas depois de 2007.
} 
suas primeiras turmas no fim de 2010. De acordo com Flores (2010), a UnB convidou a UFT para participar do Setentrional mesmo com o edital já fechado, o que justifica o fato de nenhum dos professores da UFT ter participado ativamente do processo de elaboração do projeto pedagógico do curso. Isto mostra que, se a UFRN foi protagonista na implantação da EaD via Pró-Licenciatura em seu consórcio, no Setentrional, a UFT teve um papel figurativo, de universidade que aderiu a um projeto já em andamento. Isto fica claro quando vemos que nenhum dos 21 professores que assinam a proposta de curso do Setentrional pertence aos quadros da UFT.

Apesar disso, passaram a ser promovidos encontros anuais para a discussão de aspectos relacionados à EaD no âmbito da universidade, entre 2005 e 2007. Tais eventos contaram com a participação de destacados profissionais da área, todos com mestrado ou doutorado em $\mathrm{EaD}$, incluindo coordenadores de $\mathrm{EaD}$ de universidades tradicionais na área, como a Universidade Federal de Mato Grosso (UFMT) e a própria UFRN. Em 2008, com a expectativa de expansão da EaD na UFT, surge o Centro de Novas Tecnologias Educacionais, o CNTE (atual DTE), como órgão da UFT responsável pela implantação e pelo gerenciamento da $\mathrm{EaD}$; portanto, o órgão análogo à Sedis na UFRN.

As áreas de Matemática e Ciências são aquelas em que o estado do Tocantins mais sofre de carência de professores na educação básica e, segundo os PPC da UFT, foi esta a razão que moveu a gestão da EaD da universidade em prol da abertura de licenciaturas nessas áreas. A partir de entendimentos estabelecidos entre os coordenadores de $\mathrm{EaD}$ das universidades potiguar e tocantinense, de acordo com o entrevistado $\mathrm{Y}$, ficou definido que o projeto político-pedagógico e o material didático a serem utilizados no Tocantins seriam cedidos e adaptados a partir daqueles que eram utilizados desde 2007 no estado nordestino, nos cursos homólogos. Tal cessão não se repetiu com nenhuma outra universidade, apesar da posição de referência e de liderança ocupada pela UFRN na área de $\mathrm{EaD}$. O curso de Matemática da UFT acabou tendo o seu PPC aprovado apenas em fevereiro de 2012. No entanto, todas as referências freireanas foram eliminadas, apesar de tal PPC afirmar que a base de sua constituição é o projeto pedagógico da UFRN.

De acordo com Cunha (2006), a ideia da constituição de consórcio de universidades para oferecer cursos EaD tem como consequência a adesão a um projeto pedagógico único, dissociado dos respectivos projetos pedagógicos implementados nos seus cursos presenciais. Caso similar ocorreu entre UFRN e UFT, embora sem a formalização de um consórcio. Para o autor, se, por um lado, isto facilita a adoção de um projeto pedagógico inovador, por outro, a $\mathrm{EaD}$ se isola dos cursos presenciais existentes, dificultando a realimentação de eventuais 
inovações nestes últimos, bem como tende a tolher o desenvolvimento cultural diversificado entre as instituições. O lado positivo está na redução de custos e de trabalho na UFT, que não tinha docentes qualificados em número suficiente para fazer a elaboração completa dos materiais didáticos. Aquele autor ainda se preocupa com a eventual adoção de projetos pedagógicos dissociados da cultura da universidade que recebe o projeto pedagógico. No caso da UFT, uma instituição com pouca tradição e menos de uma década de existência, não chega a ser fator de preocupação. O maior problema não estava na opção pelo tema gerador, mas na necessidade de sua alteração.

O início dos cursos da UFRN ocorreu oficialmente em 2005, mas, em realidade, as primeiras disciplinas só foram ofertadas no primeiro semestre de $2006^{14}$, de acordo com o entrevistado B. A concorrência dos vestibulares raramente superou a unidade na relação candidato por vaga. Há casos extremos de baixa concorrência, como no concurso 2007/1, em que apenas 13 candidatos disputaram as 50 vagas ofertadas no polo de Macau (RN) para o curso de Química. Quando questionado sobre a existência ou não de demanda reprimida para a formação de novos professores no Rio Grande do Norte, o entrevistado $\mathbf{J}$ diz que as entidades divergem: a Secretaria Estadual de Educação potiguar afirmaria que não há; já a Undime afirmaria que ainda faltam professores. Tal situação não foi verificada na primeira seleção da UFT, no segundo semestre de 2010. Entre Biologia, Física e Química, cursos ofertados pelo edital 106, os dois últimos cursos tiveram muito menos inscrições, sendo Química ainda menos que Física, fato observado tanto entre egressos do ensino Médio quanto entre professores da rede pública. Mesmo assim, todos os cursos tiveram concorrência superior a um candidato por vaga, o que mostra ainda haver demanda pelos cursos.

\subsection{A elaboração dos projetos pedagógicos}

Durante o processo de implantação dos cursos da UFRN, não havia colegiados de curso separados, mas um único colegiado de EaD. O conceito por trás dessa ideia, que visava a atender a interesses pedagógicos e de economia de recursos, era o de núcleo comum, com projetos pedagógicos comuns, disciplinas e grades comuns em pelo menos quatro semestres iniciais, visando à interdisciplinaridade e, também, à redução de custos e racionalização de

\footnotetext{
${ }^{14}$ Tal processo foi semelhante na UFT, em que o início das turmas ocorreu oficialmente em 2010, mas as disciplinas regulares só foram ofertadas a partir do primeiro semestre de 2011.
} 
esforços. A ideia de cursos que fossem semelhantes em suas grades curriculares era a de convergência de demandas, como logística, pedagogia etc. Na visão do entrevistado $\mathrm{D}$, isto mostraria uma preocupação da UFRN com o aluno que a universidade visava formar: um professor de interior, cuja necessidade maior é a de uma formação básica completa. Ilustraria, também, esta preocupação, o fato de o curso de Matemática, que surgiu em conjunto com os cursos de Química e de Física, contemplar conteúdos geralmente ausentes do currículo de ensino superior, como a Matemática do ensino Básico. O entrevistado B declarou que a prioridade foi a contextualização dos componentes curriculares à realidade local dos professores da educação básica do interior nordestino, o que, em muitos casos, pode ser estendido a um contexto maior.

O projeto pedagógico que orientou a composição do material didático, elaborado sob a liderança da professora Marta Pernambuco, previa a utilização de um tema gerador. No caso da UFRN, o tema gerador escolhido foi a seca nordestina. O objetivo seria o de romper o conceito embutido na grade tradicional dos cursos superiores, com um primeiro ciclo de conteúdos integrados, e que não separasse teoria e prática. A única disciplina que, de certa forma, destoou do conjunto é a que viria a se chamar "Informática e Educação". O objetivo desta disciplina, dada a grande falta de familiaridade dos alunos do interior com a informática à época, era o de fazer com que o aluno aprendesse a "ligar o computador", segundo o entrevistado D.

Os nomes das outras disciplinas, "Matemática e Realidade", "Educação e Realidade" ou "Ciências da Natureza e Realidade", teriam sido dados para que as suas ementas e seus materiais didáticos, no momento em que viessem a ser elaborados, fossem mais voltados à formação de professores, desprendendo da noção puramente acadêmica. A intenção seria a de transmitir conteúdos que interessassem ao aluno, ao cidadão. De certa forma, esta configuração espelha a ideia de que há um grande volume de conteúdo no ensino Médio, e de que é preciso ser seletivo em relação à pertinência destes conteúdos. A ideia que guiou a confecção dos materiais e a estruturação da EaD na UFRN teria sido a de ensinar o aluno, futuro professor, a estudar sozinho e a aprender fazendo. A "realidade" deveria ser o mais importante objeto de estudo. Em suma, é possível perceber que os professores do núcleo inicial da EaD na UFRN abraçaram e defendem, até hoje, o projeto pedagógico dos cursos com viés freireano, ainda que, para o entrevistado $\mathrm{D}$, tais professores não tenham conseguido manter sua coerência até o final.

Com a decisão do coordenador UAB da UFT de que os projetos pedagógicos dos cursos seriam os mesmos do Rio Grande do Norte, e com a definição dos coordenadores 
destes cursos, em agosto de 2008, iniciaram-se os trabalhos dentro do CNTE (atual DTE) para formatar a proposta dos novos cursos e submetê-la ao Conselho de Ensino, Pesquisa e Extensão. Um dos participantes mais ativos deste processo foi o então pró-reitor de Graduação da UFT, segundo o entrevistado Y.

As adaptações dos PPC do Rio Grande do Norte para o Tocantins foram discutidas durante o fim de 2008 e o início de 2009 por três pessoas, de acordo com o entrevistado C: os coordenadores designados dos dois cursos em conjunto com um pedagogo que, à época, atuava no CNTE (atual DTE). Ao pró-reitor cabia receber o documento com alterações, “corrigir", segundo o entrevistado C, e devolver aos três professores. Algumas das alterações propostas ocorreram em ambos os PPC, ou seja, tanto no do curso de Física quanto no de Química, enquanto outras foram adaptações particulares de cada curso. A finalização desta etapa se deu em abril de 2009. Ainda no primeiro semestre de 2009, finalmente, foram aprovados os PPC e estruturas curriculares dos cursos e dadas pelo Conselho de Ensino, Pesquisa e Extensão as suas autorizações para abertura.

Praticamente nenhuma experiência do curso de Biologia foi aproveitada para os cursos de Física e de Química na UFT, pois, além de haver diferenças significativas em termos da estrutura curricular, localização dos cursos (polos de oferta), número e importância dos encontros presenciais, entre outros aspectos, os projetos pedagógicos dos cursos tinham origens distintas. Da mesma forma, apesar de a UFT já possuir licenciaturas presenciais em Ciências, ofertadas desde 2009 no campus de Araguaína, nem os recursos humanos, nem os planos político-pedagógicos foram aproveitados nos cursos EaD. Situação oposta foi observada na UFPI, onde as estruturas curriculares das licenciaturas em Física e em Química a distância são exatamente iguais às dos cursos congêneres presenciais, o que não ocorre na UFT nem na UFRN. Se esta situação é positiva por permitir a mobilidade de um aluno da modalidade a distância para a presencial e vice-versa, por outro lado, é negativa porque, na UFPI, perde-se a flexibilidade e a possibilidade de se aproveitar melhor as vantagens da modalidade. Outro grande problema é o fato de a grade curricular da licenciatura ter muitos componentes comuns ao bacharelado, sendo que, o que se espera, é justamente o oposto: que, na $\mathrm{EaD}$, o curso de licenciatura quebre com os tradicionalismos e os engessamentos que só fazem algum sentido em uma formação de bacharéis - nem a licenciatura presencial deveria admitir. Um exemplo, só para efeito de conclusão, é o excesso de conteúdos e o uso exagerado de tecnicismos.

Mas, se de um lado, a estrutura dos cursos já existentes na UFT é bem distinta das novas licenciaturas criadas, por outro, há uma semelhança no perfil dos profissionais: ambos 
são cursos feitos por bacharéis, mestres e doutores na área da ciência básica, e não no ensino de ciências. Os problemas, os cuidados e, eventualmente, as vantagens derivadas disto, portanto, são comuns. A maior desvantagem é o desconhecimento sobre o que se tem feito na área de educação e, mais especificamente, em ensino de Ciências. Uma possível vantagem, dependendo do perfil do profissional, é a possibilidade de ele estar disposto a aprender, sem os vícios e os preconceitos que alguns professores da área específica mantêm, naturalmente, pelo tempo de atividade.

Olhemos para os PPC. As alterações mais notáveis observadas em ambos os cursos, em relação aos primeiros $\mathrm{PPC}^{15}$ da UFRN, foram as seguintes:

\section{a) Inclusão de texto justificando a escolha da UFRN como base para o PPC da UFT}

O texto que segue é um excerto do PPC de Física (o PPC de Química tem texto similar):

O curso será oferecido baseado no Projeto Pedagógico do curso de Física na modalidade EaD, da Universidade Federal do Rio Grande do Norte, que cederá à Universidade Federal do Tocantins a matriz do material didático do curso, ficando sob a responsabilidade desta instituição a adequação do material à realidade local, a reprodução do mesmo e a oferta do curso. A escolha pelo curso desta Instituição de Ensino foi motivada pela já acumulada experiência que está instituição conquistou nos últimos anos, expressa na riqueza e qualidade do material didático produzido e reconhecido pelo MEC e aprovada pelos estudantes que têm demonstrado grande interação com o curso e índices de evasão inferiores aos do curso de Física presencial. Além disso, convém mencionar a economia de recursos humanos e materiais na elaboração dos fascículos e da multimídia com a utilização do material já desenvolvido pela Universidade Federal do Rio Grande [do] Norte.

Esse curso visa também [a] atender a uma formação interdisciplinar do licenciado, superando as fragmentações que a excessiva disciplinaridade trouxe aos currículos de Física e que tanto comprometem a formação docente para atuar na Educação Básica. Conforme previsto na proposta metodológica do curso, será produzido, pelos docentes da UFT, material didático complementar na forma de fascículos e atividades abordando características peculiares do Estado como os Biomas do Cerrado, Amazônia, Pantanal e a transição de biomas, além de um fascículo que aborde a questão das energias alternativas. A produção destes materiais será de responsabilidade da UFT, por meio de seu quadro docente qualificado (UNIVERSIDADE FEDERAL DO TOCANTINS, 2009, p.15-16).

Nota-se, no trecho acima reproduzido, que os elaboradores dos PPC da UFT já compreendiam a falta de aplicabilidade do tema gerador potiguar à realidade tocantinense, e que já havia uma sugestão, detectada pelos elaboradores, de que o novo tema gerador poderia ter relação com os biomas característicos do Tocantins. A inclusão do tema "energias

\footnotetext{
${ }^{15}$ Tais PPC nunca foram efetivamente aplicados, uma vez que passaram por revisão antes mesmo do início dos cursos no Rio Grande do Norte, em especial a grade curricular. Entretanto, os "primeiros PPC" eram os únicos documentos constantes da página da Sedis-UFRN até março de 2012, mais de seis anos após a sua elaboração. Voltarei a mencioná-los no texto, referindo-me a eles como "primeiros PPC".
} 
alternativas" também tem a sua razão de ser: trata-se de uma das cinco temáticas prioritárias da UFT, as quais são: "identidade, cultura e territorialidade", "agropecuária e meio ambiente", "biodiversidade e mudanças climáticas", "educação" e "fontes de energia renovada" (UNIVERSIDADE FEDERAL DO TOCANTINS, 2012). Possivelmente, os elaboradores dos PPC tocantinenses, ao destacar "energias alternativas", tenham entendido que tal temática merecesse destaque ou que não se incluísse no estudo dos biomas locais.

É importante notar que muitos dos alunos dos cursos que se constituíram, sejam os da UFRN ou os da UFT, são da zona urbana. Desta forma, temas geradores que atendessem a este público também mereceriam discussão e, possivelmente, fossem temas igualmente pertinentes. Pernambuco (1994) sugere alguns elementos que poderiam constituir temas geradores urbanos: moradia, transporte e trabalho, como mais básicos; relações de convivência e equipamentos e serviços de uso coletivo (educação, saúde, saneamento, transporte), em um segundo plano. Em uma reforma de PPC, caso seja mantido o viés freireano, tais temas merecem entrar na pauta de discussões.

Percebe-se, também, a menção a índices de evasão inferiores na EaD em relação aos cursos congêneres presenciais. De fato, o entrevistado D relatou que, na UFRN, isto teria ocorrido, embora não tenhamos tido acesso a números que pudessem corroborar ou refutar tal informação.

Por fim, vale destacar que, dos dois materiais que o trecho afirmava que seriam confeccionados, apenas um o foi: o que se refere aos biomas locais. Mais adiante, trato do processo de sua confecção. O fascículo de energias alternativas não foi escrito, tampouco há qualquer expectativa neste sentido.

\section{b) Contextualização da realidade do estado e adaptação das justificativas do projeto}

Novamente aqui, o curso de Química teve, em seu PPC, um texto ligeiramente diferente do que se lê abaixo, que é do curso de Física, mas sem que haja algo que mereça destaque particular.

O Estado do Tocantins caracteriza-se por ser multicultural, relativamente extenso e com baixa densidade demográfica (apenas 4,2 hab. $/ \mathrm{km}^{2}$ ). O caráter heterogêneo da população tocantinense e a grande necessidade de promover a melhoria na qualidade de vida da população impõem à UFT o desafio de promover práticas educativas que elevem o nível de vida dessa população. Conforme o Atlas de Desenvolvimento Humano (Unesco), com dados relativos ao ano de 2000, o Índice de Desenvolvimento Humano Municipal (IDH-M) é de 0,710 , sendo o $16^{\circ}$ do Brasil e estando em penúltimo lugar da Região Norte. Podemos entender o motivo dessa classificação, através dos dados seguintes:

- A expectativa de vida é de 65,2 anos;

- A renda per capita média é de 172,6 reais;

- Há 50,8 \% de pessoas com renda per capita de menos de 75,00; 
- A média de anos de estudo das pessoas com 25 anos ou mais é de 4,7 anos. É a segunda menor da Região Norte;

- $\quad$ Existem $24 \%$ de analfabetos;

- $\quad 46,8 \%$ das pessoas têm menos de quatro anos de estudo;

- O percentual de repetência no ensino fundamental é de $22,1 \%$; no ensino médio, é de $15,3 \%$;

- O percentual de evasão no ensino fundamental é de 14,6\%; no ensino médio, $10,6 \%$.

Diante da necessidade de melhoria do ensino fundamental e do ensino médio e buscando atender às demandas submetidas a esta Universidade, a Fundação Universidade Federal do Tocantins vem propor a oferta do curso de Licenciatura em Física a distância. Este projeto tem como objetivo contribuir para a formação de professores no campo da Física, cientes de sua condição de cidadãos comprometidos com princípios éticos, inserção histórico-social (dignidade humana, respeito mútuo, responsabilidade, solidariedade), envolvimento com as questões ambientais e compromissos com a sociedade.

A opção pelo curso de Licenciatura em Física deve-se ao fato de ser uma das áreas do conhecimento com maior deficiência de professores graduados e capacitados para o seu ensino no Estado. Segundo dados da Secretaria de Educação do Estado do Tocantins, há uma demanda de aproximadamente 400 professores para serem capacitados, além da demanda reprimida vinda dos egressos do ensino médio. (UNIVERSIDADE FEDERAL DO TOCANTINS, 2009, p.18-19).

A justificativa do projeto, baseada em indicativos socioeconômicos, é significativamente diferente da justificativa usada no Rio Grande do Norte. O curso de Física potiguar fez uso de informações bem mais específicas, como o fato de, à época, apenas $12 \%$ dos professores de Física daquele estado serem formados na área, bem como referências quantitativas à impossibilidade de se atender ao preconizado pela LDB diante do baixo número de novos licenciandos em Física. O PPC de Química, embora não traga informações numéricas sobre o déficit de professores da área, também alicerçou a sua justificativa no baixo número de docentes licenciados em geral.

Assim, o que se percebe é que o PPC da UFT, supostamente, vê o aumento do quadro docente como uma via possível para a alteração do quadro econômico e social do estado, algo que a justificativa usada no Rio Grande do Norte não chega a aventar, apesar de esse estado compartilhar com o Tocantins muitos dos maus indicadores sociais. Neste ponto, o PPC da UFT é mais freireano, no sentido de enxergar a formação de professores conscientes como fator de mudança social, do que o PPC da UFRN. Também dá foco no aluno, ao tratar dos percentuais de repetência e evasão, e não no professor, como a UFRN. Por outro lado, peca ao não deixar clara a razão pela opção pelos cursos de Física e de Química, em lugar de tantos outros.

Uma das possibilidades teria sido mencionar que o curso de Física da UFT seria, como acabou sendo, o primeiro do estado na modalidade a distância. O de Química, por outro lado, não: em Xambioá, a Universidade de Uberaba ofertou a primeira licenciatura em Química a 
distância do Tocantins. Tal curso não terá continuidade, pois, após assinatura do Termo de Saneamento de Deficiências entre a Universidade de Uberaba e o MEC, definiu-se que as turmas já matriculadas concluirão o curso, mas não haverá novos ingressos.

\title{
c) Adaptação da seção de diretrizes metodológicas
}

Tal seção é rigorosamente igual à seção homóloga dos PPC da UFRN, exceto pela conversão das notas de rodapé em texto corrido, pela alteração da palavra "disciplina" pela expressão "componente curricular", e pela alteração do primeiro parágrafo, que passou a ter a seguinte redação:

\begin{abstract}
"Além dos aspectos intrínsecos ao ensino a distância, existem elementos inovadores, de ordem geral, que constituem as diretrizes que norteiam a proposta metodológica a ser implementada: tema gerador, que no caso da presente proposta será os diferentes biomas do Tocantins e energias alternativas; a abordagem problematizadora, no que se refere ao método pedagógico adotado; a noção de conceitos unificadores, para a parte instrucional do programa do curso; e a forma como conceitos de Física Moderna e Contemporânea são tratados, permeando praticamente todas as componentes curriculares e recebendo particular atenção na estruturação do curso como um todo." (UNIVERSIDADE FEDERAL DO TOCANTINS, 2009, p.26; grifos da versão original).
\end{abstract}

Aqui fica mais clara ainda a escolha de um novo tema gerador. O que merece questionamento é a definição de um tema gerador "de cima para baixo", imposto pelo educador que elabora a proposta, já que, até aquele momento, não havia discussão externa dos PPC. Como o entrevistado $\mathrm{C}$ declarou, apenas três professores discutiam a proposta. Com isto, perdeu-se por completo a verdadeira essência do uso do tema gerador, que é a sua busca junto ao público educando. Neste sentido, vale reproduzir, para efeitos de discussão, parte do tópico "O tema gerador" presente no PPC de licenciatura em Física da UFT:

A escolha de um tema gerador que organize os conteúdos curriculares deve partir do estudo da realidade para a qual o curso se destina. Ele é extraído da problematização da prática de vida dos alunos e é, a partir daí, recriado, ressignificado, no confronto com os conhecimentos aportados pela Ciência. Assim, o tema gerador traz as questões tais quais foram explicitadas na fala dos alunos; são questões que os inquietam e para as quais as respostas de senso comum já não satisfazem. Elas podem ser, em sua formulação original, questões ingênuas, mas que ao longo do processo e com os aportes dos novos conhecimentos, vão se sofisticando de modo que ao final elas possam se apresentar com um saber construído em um patamar que supera a insatisfação do saber do senso comum.

Atualmente, um dos assuntos mais abordados no cenário político, educacional e social é a preservação do meio-ambiente, tendo em vista o grande número de catástrofes e alterações climáticas ocorridas (assunto que já deveria ter sido tratado com tamanha relevância há anos atrás). A discussão deste tema nos remete a uma reflexão sobre as riquezas da biodiversidade e a destruição da Amazônia.

Toda esta riqueza natural vem sendo degradada ao longo dos últimos 40 anos com a crescente expansão das atividades agropecuárias, aumento da demanda de carvão vegetal, expansão imobiliária com suas redes de infraestrutura, além da 
construção de barragens para hidrelétricas. Estas atividades provocam alterações ecológicas que consequentemente levam ao empobrecimento biológico do cerrado e outros biomas aqui existentes.

A UFT tem como missão "produzir e difundir conhecimentos para formar cidadãos e profissionais qualificados, comprometidos com o desenvolvimento sustentável da Amazônia.” (Planejamento Estratégico, 2006 - 2010, pág. 25). O estado do Tocantins tem uma das maiores biodiversidades do Brasil, o que permite o estudo de vários fenômenos que se formam na região e fontes de energias renováveis, visando a atender às comunidades locais e a minimizar os impactos negativos no meio ambiente.

A diversidade biológica do Brasil e em especial o seu componente vegetal, é considerada uma importante fonte de riqueza, porém qualquer retribuição duradoura em benefícios sociais dependerá muito da manutenção do equilíbrio entre a exploração e a substituição dos organismos, cuidando para que os processos exploratórios não excedam a capacidade regenerativa natural.

A Floresta Amazônica e os biomas existentes na nossa região, em especial o cerrado, são áreas estratégias para pesquisa, como por exemplo, de bioprospecção de princípios ativos bem como para a conservação de sua biodiversidade. Neste contexto, o curso de licenciatura em Física tem como tema gerador, os diferentes biomas do Tocantins e as energias alternativas. As respostas às questões problematizadas serão buscadas nos conteúdos específicos da área (UNIVERSIDADE FEDERAL DO TOCANTINS, 2009, p.30-32).

Enquanto o primeiro parágrafo afirma claramente que o tema gerador emerge da problemática dos alunos, observa-se, nos demais parágrafos, um redirecionamento do foco a um difuso interesse (“cenário político, educacional e social”), à missão da própria universidade e à mera existência do bioma local. No único trecho em que se mencionam as "comunidades locais", a preocupação é a de "atendê-las", e não a de apresentar um saber ressignificado, como proposto no primeiro parágrafo.

O contraste observado entre esta seção adaptada e a sua original no PPC de Física da UFRN é muito expressivo. Reproduzimos o trecho correspondente logo abaixo, à exceção do primeiro parágrafo, que não foi modificado na UFT.

O Curso de Graduação a distância de Licenciatura em Física, da UFRN, se destina prioritariamente a alunos residentes nos estados da região Nordeste Setentrional-Oriental, que inclui os estados do Rio Grande do Norte, Paraíba, Pernambuco, Alagoas e Sergipe. Trata-se de uma das menos desenvolvidas regiões do país, estados inseridos em uma região pobre do país, que padece de problemas sociais graves como fome, desemprego, migração. Esta situação tem como um dos seus determinantes a falta de chuvas regulares, gerando o fenômeno da seca, aparentemente insolúvel problema do nordeste brasileiro.

A seca e a falta de um manejo adequado dos recursos hídricos são costumeiramente apontadas pela população como uma das causas das mazelas sociais que atingem a região. Faz parte do discurso e da compreensão da sua própria situação, entender que ocorre fome porque o que se planta não "vinga" por falta de água. Assim, em uma região tradicionalmente agrícola, não ter como sobreviver da agricultura significa não ter outra fonte de renda. $\mathrm{O}$ resultado natural é a migração para os espaços urbanos: a seca agindo como fator de expulsão e as oportunidades dos grandes centros, como fator de atração. É nesta realidade que os futuros professores, graduados por este curso, irão atuar. 
Seca e água foi, então, o tema gerador escolhido para nortear os conteúdos deste currículo. Seca, por ser o tema regional apontado como gerador de problemas de vida; água, como uma questão mais global, que avança na questão específica da seca. As respostas às questões problematizadas serão buscadas nos conteúdos específicos da área (UNIVERSIDADE FEDERAL DO RIO GRANDE DO NORTE, 2004, p.17).

O foco, aqui, claramente é outro: a população é que ganha voz na justificativa, como se espera que seja. Fica explícita a falta de compreensão plena, por parte da equipe pedagógica da UFT, sobre o que é o tema gerador na visão freireana. Não está claro, portanto, que o tema gerador é mais do que um tema multidisciplinar, mas um tema multidisciplinar obtido a partir da necessidade do povo, da necessidade do educando.

Por outro lado, a página de internet sobre a EaD na UFT (UNIVERSIDADE FEDERAL DO TOCANTINS, 2011) parece mais ciente dos objetivos freireanos, ao afirmar que "a EaD na UFT está em consonância com a missão desta instituição e busca difundir e democratizar a educação superior no estado do Tocantins, formando profissionais comprometidos e capazes de atuar de forma crítica e transformadora em sua realidade".

Os projetos pedagógicos apresentados nesta seção não diferem muito, por exemplo, do projeto do curso de licenciatura em Física EaD da UFSC, um dos dois cursos de Física criados no país antes do curso da UFRN. Segundo Fernandes (2007), tal projeto mostra consciência dos diversos desafios e das novas possibilidades derivadas da diversificação da modalidade, tendo a meta de desenvolver atitudes reflexivas e investigativas, ressignificando a experiência prévia dos alunos, uma característica fortemente presente nos PPC da UFRN e da UFT, como vimos.

$\mathrm{Na}$ seção 3.3, tratei das diretrizes metodológicas do programa Pró-Licenciatura. Os projetos pedagógicos da UFSC e da UFRN, inicialmente propostos dentro daquele programa, se encaixavam naquelas diretrizes, embora de forma limitada. Isto se deve, em parte, a um excesso de detalhamento e, portanto, de condições restritivas da proposta do MEC. Um exemplo é a exigência de que o educador devesse manter um diário e realizar produções não textuais. Outra é a exigência de "forte carga de leitura", apesar de os envolvidos poderem ser capazes de aprender mais a partir de outros suportes (três, no mínimo, eram exigidos: impresso, vídeo e digital). É positivo que as universidades tenham buscado a sua experiência e feito os seus cursos EaD "desobedecendo" as diretrizes do MEC, mas experimentando e, frequentemente, acertando em formas variadas de se fazer formação de professores a distância no Brasil. 


\subsection{Organização curricular e conteúdos programáticos}

O semestre inicial dos cursos de Física e de Química da UFRN é o único cuja grade manteve-se idêntica em ambos os cursos. Esta união foi se desfazendo ao longo do semestre posterior e, depois destes primeiros dois semestres de curso, com as grades já bem distintas, cada professor conteudista, bem como cada coordenador de curso, passou a atuar de forma particular. Apesar disso, os cursos mantiveram uma identidade comum. Para o entrevistado D, com a interrupção das frequentes reuniões para definições de ordem pedagógica, a grade deixou de ter dialogicidade entre as disciplinas, o que representa uma ruptura com o referencial freireano.

Esta situação não impediu que alguns professores destacassem aspectos muito interessantes do currículo. $\mathrm{O}$ entrevistado $\mathrm{M}$ destaca que foi garantida, como meta importante, a não repetição de conteúdos em disciplinas distintas ${ }^{16}$. O mesmo entrevistado diz que o componente curricular de "Energia" é uma bela disciplina, presente nos currículos dos dois cursos, com um material muito bem escrito. O entrevistado D também cita "Energia" como exemplo de disciplina que conseguiu atender primorosamente ao objetivo de ensinar o aluno a estudar sozinho e a aprender fazendo, por meio do estudo da realidade como ponto central. $\mathrm{O}$ mesmo entrevistado diz que esse objetivo foi alcançado especialmente nos componentes curriculares que tradicionalmente não fazem parte da grade de cursos de Física e de Química. É o caso de "Energia".

$\mathrm{O}$ entrevistado $\mathrm{M}$ também destaca, como ponto positivo da $\mathrm{EaD}$, o fato de que algumas das inovações curriculares e pedagógicas terem acabado refletidas na educação presencial no âmbito da UFRN. Uma forma direta de isto acontecer é quando o professor da educação presencial é convidado para atuar na $\mathrm{EaD}$, tendo, no novo ambiente, novas ideias que, eventualmente, podem causar uma mudança no estado de equilíbrio da prática docente na educação presencial.

O entrevistado B destaca que algumas disciplinas do curso de Física são exclusivas, não havendo par em outras licenciaturas. Entre elas, estão "Conceitos de Física Nuclear e de Partículas Elementares"; "Astrofísica e Cosmologia"; "Conceitos de Física da Matéria Condensada"; "Ética, Ciência e Educação"; e, por fim, "Relatividade" e "Introdução à Física

\footnotetext{
${ }^{16} \mathrm{O}$ entrevistado $\mathrm{M}$ deu como exemplo o conteúdo de teoria dos orbitais moleculares, que não se repete nas ementas de Química Orgânica e de Inorgânica, como em muitos cursos de Química.
} 
Quântica" como duas disciplinas independentes. Tratam-se, segundo o professor, de disciplinas sugeridas, aceitas e valorizadas pelo colegiado do curso.

O professor André Ferrer Pinto Martins, físico do Departamento de Educação da UFRN, chamou a atenção ${ }^{17}$ para a presença da disciplina "Pesquisa em Ensino de Física", no currículo de Física, algo que nenhum dos entrevistados destacou. $\mathrm{O}$ mesmo professor apontou o quão rara é a presença desta disciplina nas grades de licenciaturas, em qualquer área. De fato, não há uma disciplina congênere a essa no currículo da Química. Trata-se, sem dúvida, de uma disciplina importante em pelo menos dois contextos: para possibilitar ao futuro professor a eficiente pesquisa sobre a própria prática, e para permitir que ele, com mais flexibilidade, segurança e, especialmente, frequência, possa fazer uso de novos conhecimentos derivados da produção acadêmica na área de Ensino de Ciências. Outra característica notável, que mostra enorme preocupação com a ampliação das experiências dos alunos em relação à prática docente, para o entrevistado $\mathrm{M}$, é a existência de várias disciplinas de "Instrumentação para o Ensino" (no curso de Física, são duas; no de Química, quatro).

A ideia de contemplar conteúdos que habilitassem o professor formado a ministrar também a disciplina de Ciências para o ensino Fundamental, sem, no entanto, abandonar os componentes curriculares específicos levou à inclusão, no primeiro semestre, de uma disciplina que contemplasse os conteúdos de Biologia nos cursos de Física e de Química. Mas o entrevistado $\mathrm{M}$ acredita que, pelo fato de a Biologia ser muito pouco abordada nos semestres posteriores, ainda permanece um hiato na formação dos professores para a sua atuação eficiente como professores de Ciências para o ensino Fundamental. O entrevistado J afirma que a introdução de mais créditos de Biologia para formar habilitados também em Ciências para o ensino Fundamental é meta para uma futura reforma curricular.

De fato, nem tudo é positivo. Uma inovação que foi abandonada na UFRN é a inexistência de pré-requisitos. Hoje, há um sistema de pré-requisitos para a matrícula em determinadas disciplinas avançadas na grade curricular. Isto tem feito o curso andar mais devagar, já que é alta a taxa de retenção em disciplinas como "Cálculo I" (ambas as grades) e "Arquitetura Atômica e Molecular" (grade de Química), disciplinas que representam pré-requisito para muitas outras. Segundo o entrevistado D, já se sabia desta alta retenção dos alunos em disciplinas de Cálculo e da Física, mas, apesar de ser uma questão recorrente e possivelmente relacionada ao fato de que os professores têm a tendência de ministrar suas

\footnotetext{
17 Trata-se de menção oral pública, ocorrida durante sua participação como examinador na defesa de tese de doutoramento de Sonia Salem, neste Programa de Pós-Graduação Interunidades em Ensino de Ciências, em maio de 2012.
} 
disciplinas da mesma forma para todos os cursos, nada foi feito no sentido de buscar a redução da taxa de reprovação. $\mathrm{O}$ entrevistado $\mathrm{M}$ também comenta esse fato, lamentando que tenha sido retomado um conceito do ensino tradicional, de que é preciso seguir uma ordem determinada de conteúdos para poder aprender. Com a presença de pré-requisitos, as disciplinas precisam ser reofertadas mais frequentemente ${ }^{18}$. O entrevistado D entende que o sistema de EaD não comporta a reprovação em massa, ao contrário da educação presencial, já que as reofertas não são regulares. Caso isto ocorra, completa o entrevistado, o curso EaD deveria mudar de modalidade e passar a ser presencial. A UFT manteve o ideal original e não estabeleceu pré-requisitos. Isto tem sido positivo, pois permite que as turmas se mantenham juntas, algo que serve como incentivo cruzado entre alunos para evitar a desistência.

Outra tentativa da UFRN foi a de eliminar conteúdos desnecessários ou supérfluos, algo que ainda não se conseguiu completar, mas que se pretende fazer nas próximas reformas das grades de ambos os cursos. O entrevistado $\mathrm{M}$ cita como exemplo a presença, por exemplo, de Química Quântica em currículos de cursos de Farmácia, e completa dizendo que os cursos de licenciatura da UFRN sofrem do mesmo mal. O entrevistado $G$ entende que a atual grade ainda não consegue se diferenciar suficientemente bem da grade da licenciatura presencial, além de haver, em sua opinião, a abordagem de um excesso de conteúdos. O entrevistado B afirma o mesmo, lembrando que, ao contrário dos cursos de Matemática e de Química, o curso de Física ainda não havia passado, até 2011, por nenhuma alteração na grade, sendo este último curso o detentor da maior carga horária entre as três licenciaturas abertas em 2005.

O edital do programa Pró-Licenciatura previa a montagem de laboratórios. Dada esta disponibilidade, a ideia na UFRN era a de não separar a teoria da prática dentro de cada componente curricular. Ambos os cursos passaram a ser montados com disciplinas teórico-práticas. A ruptura em relação a este modelo só se deu no curso de Química, que foi o único avaliado pela SESu - na época, a tramitação burocrática do curso se deu em duas frentes dentro do MEC: na Seed e na SESu. No curso de Química, o avaliador, professor César Zucco, da UFSC, teria recomendado, segundo o entrevistado D, que as disciplinas práticas e teóricas fossem separadas. A ideia do avaliador teria sido a de que, como o curso da UFRN era o primeiro do país na modalidade, ele serviria de modelo para outros cursos, inclusive em universidades privadas. A existência de um padrão que não definisse claramente qual a carga horária prática poderia servir de subterfúgio a certas universidades para que se reduzisse a

\footnotetext{
${ }^{18}$ A reoferta ocorre, no mínimo, uma vez ao ano; há antecipação de abertura de disciplina no caso de haver alunos formandos potenciais que dependam do cumprimento dos referidos créditos.
} 
parte prática (e cara) do curso, havendo, assim, um risco de piora da qualidade. O curso de Física manteve o modelo de integração teoria-prática por não ter passado por avaliação in loco, embora também tenha tido a sua proposta aprovada, de acordo com o entrevistado B. Assim, as duas disciplinas obrigatórias com atribuição de carga horária experimental na grade do curso de Física são "Física Experimental e Análise Estatística de Dados" e "Física Moderna Experimental". Nas demais, fica a critério dos professores ministrantes a elaboração de experimentos, embora, na UFRN, isto seja incentivado. Não consegui apurar se há tal incentivo na UFT, embora o entrevistado $\mathrm{Z}$ tenha relatado que já teria havido aulas de laboratório no curso de Física, ou seja, foram ministradas aulas práticas em disciplinas que não as duas há pouco mencionadas.

Os dois cursos do Tocantins tiveram a introdução de duas disciplinas sem equivalência no currículo potiguar: "Sociedade, Cultura e História da Educação”, no terceiro semestre, e "Currículo, Política e Gestão Educacional”, no quarto semestre. Trata-se de disciplinas introduzidas para servir àquilo que se convencionou ser necessário à formação do professor. São disciplinas que quebram com a vertente excessivamente prática dos componentes curriculares pedagógicos da grade potiguar, sem chegar a pesar demais em proporção de tempo. Por fim, também foi introduzida nos cursos da UFT uma disciplina de "Libras"19.

As grades curriculares dos cursos da UFT mostram desconhecimento ou desprezo acerca da carga horária necessária para o desenvolvimento de cada disciplina. Todos os componentes curriculares, exceto os de estágio, têm exatamente a mesma carga horária: 60 horas. Assim, existe uma natural dificuldade em acomodar certas disciplinas que, no curso da UFRN, previam 90 ou 100 horas, e na UFT são ministradas à base de 60 horas. Por outro lado, são diversas as disciplinas ministradas em 30 ou 45 horas na UFRN, enquanto na UFT são utilizadas 60 horas. Somando-se a isto o inchaço curricular, devido à manutenção de disciplinas específicas que constaram somente nos primeiros PPC da UFRN (que nunca foram efetivamente aplicados), a carga horária nominal dos cursos da UFT é extremamente grande. No caso da Física, a UFRN tem um curso de 3275 horas, incluindo-se estágios e atividades acadêmico-científico-culturais; a UFT registra 3530 horas. No curso de Química, a diferença é ainda mais expressiva: 2850 horas na UFRN ante 3965 horas na UFT.

Especificamente no curso de Física, observam-se as seguintes alterações na organização curricular: deixou de haver uma disciplina de "Química” para serem utilizados os

\footnotetext{
${ }^{19}$ Duas outras disciplinas tiveram alteração de denominação da UFRN para a UFT, sem significativa alteração na ementa: "Didática", que passou a se chamar "Didática e Formação de Professores" no Tocantins; "Psicologia da Educação", na UFT denominada "Psicologia da Aprendizagem”.
} 
materiais de "Arquitetura Atômica e Molecular" do curso de Química, restringindo o conteúdo de Química a um estudo introdutório de Química Geral. Foi retirada a disciplina "Ecologia", bem como "Conceitos de Biologia" e "Conceitos de Geofísica". Por fim, as duas disciplinas de "Instrumentação para o Ensino de Física" passaram a ser denominadas "Metodologia para o Ensino de Física". Embora, na prática, as ementas não tenham sido alteradas, a mudança na nomenclatura das disciplinas aponta para duas reflexões necessárias e subsequentes. A primeira é a de que o uso destas duas palavras, embora tenha sentidos práticos muito semelhantes, são, na essência, diferentes. Uma das diferenças se deve ao fato de a palavra "instrumentação" ser mais utilizada quando se refere a Ciências, sejam exatas ou biológicas, e a palavra "metodologia" costuma ser mais usada para as áreas de Matemática e Humanidades. De fato, as Ciências demandam mais instrumentos. Daí vem que a alteração de nome das disciplinas, embora possa ter sido realizada por um pedagogo sem uma maior reflexão, simplesmente porque a palavra "instrumentação" não faz parte do seu vocabulário profissional tanto quanto "metodologia", pode implicar, nos professores que aplicarão a disciplina, uma menor preocupação com os aspectos experimentais que, como observa Vianna (1992), estão na essência das disciplinas de Instrumentação para o Ensino. Por outro lado, a alteração pode vir a enriquecer o conteúdo destes componentes curriculares, à medida que se acresçam elementos de metodologia àqueles de instrumentação já existentes.

O curso de Química também teve alterações específicas na organização curricular: na UFRN, são 5 as disciplinas de "Instrumentação para o Ensino de Química" no primeiro $\mathrm{PPC}^{20}$, um dos orgulhos dos elaboradores da grade curricular, como se notou nas entrevistas. Já na UFT, elas foram reduzidas a apenas duas. No entanto, foram introduzidas as disciplinas "Metodologia do Ensino de Química no Ensino Fundamental" e "Metodologia do Ensino de Química no Ensino Médio", com ementas praticamente iguais a duas das ementas de "Instrumentação para o Ensino" na UFRN. Por fim, foram introduzidas no último semestre duas disciplinas: "Ética na Ciência, Tecnologia e Ensino", que, curiosamente, consta da grade do curso de Física da UFRN, mas não do curso de Química; e "Pesquisa em Ensino de Química", sendo que esta última, possivelmente por influência do currículo do curso de Física, em que tanto UFRN quanto UFT possuem "Pesquisa em Ensino de Física", mas a Química da UFRN, como se viu, não possui.

No PPC de Química da UFT, várias ementas trazem no título a identificação "Licenciatura em Física", inclusive, uma delas, tratando de um certo "Epef - Encontro de

\footnotetext{
${ }^{20}$ Entretanto, o PPC que se usou na prática só prevê 4 disciplinas com este nome.
} 
Pesquisa em Ensino de Química", evento que não existe, embora haja um evento bienal, organizado pela Sociedade Brasileira de Física (SBF), de sigla Epef, que significa "Encontro de Pesquisa em Ensino de Física”. Isto mostra que a confecção do PPC da Química teve como base o PPC da Física. Em suma, as adaptações do PPC de Química não foram feitas por pessoal da área de ensino de Ciências, o que pode justificar certos equívocos nas opções feitas durante esta adaptação. Por sorte, não foram adaptações suficientemente significativas, a ponto de invalidar a proposta, especialmente no que diz respeito à opção pelo viés freireano.

As análises realizadas neste capítulo poderiam ter sido mais completas se tivéssemos, entre os atores envolvidos na UFT, pessoas dispostas a comentar tais alterações de PPC e grade curricular. No entanto, infelizmente, diversas foram as dificuldades: entrevistados que optaram por não abordar a questão, por razões diversas; pessoas que não se deixaram entrevistar; outras pessoas sequer encontradas para comentar o trabalho realizado. 


\section{CURSOS EM FOCO: CARACTERIZAÇÃO DOS PERSONAGENS}

Passo a tratar do perfil dos atores da EaD no âmbito dos cursos pesquisados. Algumas de suas características são impostas pela própria regulamentação do sistema UAB, afinal, à exceção dos alunos, todos são bolsistas ${ }^{21}$ : coordenadores, professores e tutores. Além desta caracterização óbvia, busquei mais informações no currículo dos profissionais, obtido por meio de pesquisas na Plataforma Lattes, ou por meio de conversas pessoais, ou pela análise de documentação do curso. No caso dos alunos, questionários aplicados facilitaram a definição de seu perfil.

Vale dizer que, em maio e em julho de 2010, a convite da Capes, viajamos, eu e outro OA de Química do Tocantins, para Teresina, a fim de atuar junto ao curso de licenciatura em Química na modalidade EaD da Universidade Federal do Piauí (UFPI), para ver um curso UAB funcionando e poder implementar adequadamente os cursos no Tocantins. O referido curso já se encontrava em seu quinto semestre de funcionamento em cinco polos no interior do estado. Em ambas as visitas, tivemos a oportunidade de conhecer as experiências da UFPI, tanto em seu Centro de Educação Aberta e a Distância, na capital Teresina, quanto nos polos de Castelo do Piauí e de Piracuruca. A partir deste ponto, algumas comparações que faço também remetem a esta experiência no Piauí.

\subsection{Os alunos}

Em ambas as universidades pesquisadas, temos registros de questionários aplicados aos alunos para a sua caracterização. Na UFRN, Brito, Gomes e Fernandes (2009) compilaram questionários aplicados por tutores a 113 alunos do curso de licenciatura em Química EaD. Não há estatísticas sobre os alunos do curso de Física.

A maioria dos alunos da pesquisa potiguar é constituída de professores: $66 \%$. De acordo com as autoras, quando perguntados sobre a importância do curso superior na sua profissão, muitos apontam a questão salarial. No Piauí, segundo relatos informais dos professores com quem conversei, o perfil da maioria dos alunos também era o de professores da educação básica em busca de formação.

21 Também há a exceção dos orientadores acadêmicos, que possuem contrato de trabalho temporário com o MEC, regulado pela lei 8745, de 9 de dezembro de 1993, renovável anualmente até um máximo de 5 anos. 
A maioria dos respondentes da pesquisa potiguar diz ter entre uma e duas horas diárias para se dedicar ao estudo: $80 \%$. Apesar de terem pouco tempo para estudar, $94 \%$ deles matriculam-se em 4 ou 5 disciplinas por semestre. Dois em cada três alunos estavam fora do sistema regular de ensino havia mais de 3 anos. Na visão das autoras, todos estes fatores, especialmente quando acumulados, dificultam o aprendizado, levando à reprovação em grande escala em certas disciplinas, sendo que a pesquisa apontou que os alunos têm consciência de que esta falta de tempo afeta diretamente o seu rendimento nas disciplinas.

Outro dado obtido por Brito, Gomes e Fernandes (2009) aponta que a maioria dos alunos possui acesso à internet em casa ou no trabalho: só $2 \%$ vai ao polo para acessar a rede. Assim, o polo funcionaria como um local para a formação de grupos de estudo e interação com outros alunos e com o tutor orientador de estudos.

O perfil dos alunos ingressantes na UFRN, segundo o entrevistado G, é diversificado, com alunos mais novos, outros mais velhos, alguns já portadores de diploma de nível superior. $\mathrm{O}$ entrevistado $\mathrm{J}$ observou uma alteração no perfil dos ingressantes: se antes os professores sem a formação necessária para atuar nas turmas e níveis em que trabalhavam eram maioria nos polos, agora a maior parte das vagas são preenchidas por recém-egressos do ensino Médio. Seja como for, o entrevistado D identifica um grande problema no perfil dos alunos já no momento do ingresso, com deficiências na educação Básica. O entrevistado D reconhece a dificuldade de se repassar o conteúdo atrasado de 11, 12 anos em um único semestre. Mesmo assim, sugere algumas ações que, se não solucionam o problema, ao menos podem atenuar suas consequências: manter material de ensino fundamental e médio no Moodle para eliminar as dúvidas dos ingressantes; identificar, através da nota do Saeb, em que disciplinas os alunos têm mais dificuldade. Quanto ao conhecimento informático prático, o entrevistado B entende que, hoje, os alunos assimilaram a comunicação via ambiente virtual, ingressando, na maioria dos casos, com conhecimento suficiente.

$\mathrm{O}$ perfil dos alunos também se diferencia entre os diversos polos. $\mathrm{O}$ entrevistado $\mathrm{J}$ lembra o caso de dois polos no próprio estado do Rio Grande do Norte: enquanto em Currais Novos os alunos são muito humildes, às vezes provenientes da zona rural do município, em Nova Cruz é comum que já saibam manipular com desenvoltura o computador. A taxa de evasão, portanto, também acaba sendo diferenciada, bem como os fatores que a justificam. No caso do curso de Química, o entrevistado J aponta a elevada taxa de desistência no polo de Extremoz, que fica a menos de $20 \mathrm{~km}$ da capital Natal e, portanto, com maior possibilidade de evasão do aluno para outro curso ou instituição na capital. A evasão também teria se ampliado no polo de Currais Novos quando ocorreu a implantação de um campus do Instituto Federal 
de Educação, Ciência e Tecnologia do Rio Grande do Norte (IFRN) nesse município. O entrevistado $\mathbf{J}$ entende que a evasão alta se deve a fatores como grande resistência dos alunos ao estudo solitário, além do aumento da oferta de cursos presenciais em instituições públicas. No Rio Grande do Norte, são quatro: a UFRN, o IFRN, a Universidade Federal Rural do Semiárido (Ufersa) e a Universidade do Estado do Rio Grande do Norte (Uern).

Os alunos da UFT também responderam a um questionário, proposto por mim e aplicado a alunos dos dois cursos, nos três polos de cada um. Um total de 64 alunos respondeu às questões propostas, sendo 32 de Física e 32 de Química. Este questionário, que incluiu perguntas quantitativas e qualitativas, foi tabulado e organizado pela ferramenta Google Docs. Seus resultados encontram-se abaixo.

Tabela 4 - Cursos e polos dos respondentes da pesquisa

\begin{tabular}{l|r|r}
\hline \multicolumn{1}{c|}{ Curso/Polo } & Número de alunos & Percentual \\
\hline Física/Cristalândia & 6 & $9 \%$ \\
Física/Palmas & 18 & $28 \%$ \\
Física/Ananás & 8 & $13 \%$ \\
Química/Cristalândia & 8 & $13 \%$ \\
Química/Gurupi & 17 & $26 \%$ \\
Química/Porto Nacional & 7 & $11 \%$ \\
TOTAL & 64 & $100 \%$ \\
\hline
\end{tabular}

Tabela 5 - Respostas ao item "Antes de ingressar neste curso, ficou quanto tempo sem estudar regularmente?"

\begin{tabular}{lrr}
\hline \multicolumn{1}{c|}{ Resposta } & Número de alunos & Percentual \\
\hline Menos de 1 ano. & 22 & $34 \%$ \\
Mais de 1 ano e menos de 2 anos. & 8 & $13 \%$ \\
Mais de 2 anos e menos de 4 anos. & 10 & $16 \%$ \\
Mais de 4 anos e menos de 8 anos. & 16 & $25 \%$ \\
Mais de 8 anos e menos de 16 anos. & 7 & $11 \%$ \\
Mais de 16 anos. & 1 & $2 \%$ \\
\hline
\end{tabular}


Pela tabela 4, vemos que os respondentes da pesquisa, embora mal distribuídos pelos polos, estão simetricamente distribuídos pelos cursos, com 32 respondentes para cada curso. Houve um maior número de respondentes nas cidades maiores, mas isto não nos permite chegar a nenhuma conclusão, pois Porto Nacional, além de não ser pequena, por sua proximidade com a capital, tem muitos alunos residentes em Palmas; mesmo assim, teve baixo número de respondentes.

Na tabela 5, dois dados chamam a atenção. Um terço dos alunos praticamente não se afastou da educação regular antes de cursar as graduações aqui estudadas. Não necessariamente são recém-egressos do ensino Médio, mas, muito provavelmente, são pessoas que não precisam de nova adaptação quanto ao ritmo de estudos e disponibilidade de tempo para estudos.

Para além deste pico, temos outro, mais adiante, correspondente às pessoas que se afastaram entre 4 e 8 anos dos bancos escolares. Embora já seja conhecido o fato de a modalidade EaD servir para atender a este público que já não pode ou não quer frequentar uma universidade presencial, em um modelo mais rígido de tempo e espaço (embora potencialmente mais rico, por ocorrer em um campus universitário), é sempre importante destacar qual é o tempo mais comum em que o profissional percebe a necessidade ou o desejo de voltar a se qualificar em cursos da educação regular para obter diploma.

Percebemos, portanto, que a taxa de alunos há muito tempo afastada da educação regular é próxima àquela verificada na UFRN, embora ligeiramente menor. O fato de o questionário da UFRN ter sido aplicado na forma impressa e o nosso por meio do Moodle pode ter influenciado os números.

Tabela 6 - Respostas ao item "A opção pela modalidade a distância foi feita por quê??"

\begin{tabular}{l|rr}
\hline \multicolumn{1}{c|}{ Opções escolhidas (permitida múltipla escolha) } & Número de alunos & Percentual \\
\hline $\begin{array}{l}\text { Possibilidade de conciliar com o trabalho } \\
\begin{array}{l}\text { Dificuldade de deslocamento a uma cidade que ofereça } \\
\text { o curso presencial equivalente }\end{array}\end{array}$ & 32 & $50 \%$ \\
Possibilidade de fazer o curso gratuitamente & 25 & $39 \%$ \\
Busca por maior flexibilidade de tempo & 25 & $39 \%$ \\
Vestibular mais fácil / Curso mais fácil & 23 & $36 \%$ \\
Outros & 0 & $0 \%$ \\
\hline
\end{tabular}


Um olhar sobre a tabela 6 mostra que os alunos optam pela EaD por razões diversas, sem uma predominância muito maior de uma razão sobre as demais, em relação às limitações financeiras (curso gratuito), temporais (flexibilidade de tempo) ou espaciais (dificuldade de se deslocar a um campus universitário diariamente). Se, por um lado, é positivo que nenhum dos 64 alunos tenha acreditado que o curso a distância ou mesmo seu acesso são mais fáceis que os correspondentes cursos presenciais, por outro, deve-se olhar com cautela para o fato de $50 \%$ dos alunos acreditarem que a modalidade permitirá uma conciliação com o trabalho, o que nem sempre ocorre, dada a alta exigência de execução de atividades.

Tabela 7 - Respostas ao item "O que o levou a fazer este curso?"

\begin{tabular}{l|r|r}
\hline \multicolumn{1}{c|}{ Opções escolhidas (permitida múltipla escolha) } & Número de alunos & Percentual \\
\hline Gosto pela área de Física (ou Química) & 50 & $78 \%$ \\
Desejo por ser professor & 14 & $22 \%$ \\
Necessidade de diploma em qualquer área & 8 & $13 \%$ \\
Necessidade de diploma na área de Física (ou Química) & 7 & $11 \%$ \\
Pressão do empregador, chefia ou mercado de trabalho & 1 & $2 \%$ \\
Outros & 6 & $9 \%$ \\
\hline
\end{tabular}

Tabela 8 - Respostas ao item "Você atua como professor?"

\begin{tabular}{lrrr}
\hline \multicolumn{1}{c|}{ Opções escolhidas (permitida múltipla escolha) } & Número de alunos & Percentual \\
\hline Sim, na rede pública. & 23 & $36 \%$ \\
Sim, em instituições privadas. & 3 & $5 \%$ \\
Sim, com aulas particulares. & 4 & $6 \%$ \\
Não atualmente, mas atuei como professor na rede pública. & 9 & $14 \%$ \\
Não atualmente, mas atuei como professor na rede privada. & 2 & $3 \%$ \\
Atuo como coordenador pedagógico ou diretor. & 1 & $2 \%$ \\
Atuo em outro cargo técnico-administrativo em escolas. & 2 & $3 \%$ \\
Não, nunca atuei em escolas. & 28 & $44 \%$ \\
\hline
\end{tabular}

Os dados da tabela 7 mostram claramente que o desejo de ser professor, que moveu apenas $22 \%$ dos alunos respondentes da pesquisa, é muito reduzido entre os alunos do curso. 
Tal dado pode ter sido influenciado por uma baixa resposta daqueles que já são professores e, portanto, podem ter entendido que não desejam ser o que já são. Seja como for, observa-se que há mais alunos ingressantes interessados no fato de os cursos de licenciatura em Ciências serem "em Ciências" do que serem "de licenciatura".

Pela análise dos dados que geraram a tabela 8 , percebemos haver 26 professores na ativa (aqueles que responderam sim, em uma ou mais das três primeiras opções apresentadas na tabela). A união deste conjunto de 26 alunos-professores com o conjunto dos 14 alunos que responderam ser um motivo para cursar a licenciatura na UFT o desejo de ser professor resultou em um terceiro conjunto com 35 elementos. Ou seja, entre os que são professores e os que querem ser professores, excluídas as respostas duplicadas, temos apenas 55\% dos alunos respondentes. Esta informação confirma que, entre os alunos respondentes da pesquisa, há mais interessados na Física ou na Química (78\%) do que na Licenciatura.

O edital 99/2010 de seleção de alunos da UFT previa reserva de vagas para professores da educação básica à razão de 80\%. No edital 106/2010, já corrigido, o CTE (atual DTE) passou a atender a resoluções da UFT indevidamente descumpridas no primeiro edital, reservando apenas $50 \%$ das vagas a docentes ativos na rede pública. Uma vez que não há 50\% dos alunos como docentes ativos, a reserva de vagas se fez desnecessária. Vale notar que a UFRN não reserva vagas a professores. De fato, entre os postulantes às vagas dos cursos, os professores já são, em média, mais bem preparados do que os demais concorrentes, o que dispensaria a necessidade de reserva de vagas.

Tabela 9 - Respostas ao item "Se já atuou como professor, indique os níveis e modalidades de ensino."

\begin{tabular}{l|r|r}
\hline \multicolumn{1}{c|}{ Opções escolhidas (permitida múltipla escolha) } & Número de alunos & Percentual \\
\hline Educação Infantil. & 4 & $6 \%$ \\
$1^{\text {o ao }} 5^{\circ}$ ano do Ensino Fundamental. & 13 & $20 \%$ \\
$6^{\circ}$ ao $9^{\circ}$ ano do Ensino Fundamental. & 29 & $45 \%$ \\
Ensino Médio. & 18 & $28 \%$ \\
Ensino Superior ou Técnico. & 4 & $6 \%$ \\
Educação de Jovens e Adultos ou Supletivo. & 19 & $30 \%$ \\
Educação Especial. & 0 & $0 \%$ \\
\hline
\end{tabular}

A tabela 9 nos indica que quase todos os alunos que foram ou são professores já atuaram no segundo ciclo do ensino Fundamental. Se a expectativa é formar professores que 
possam atuar melhor no seu ambiente de trabalho, os dados mostram que não se pode relegar a segundo plano uma formação mais adequada em Ciências para o ensino Fundamental.

Tabela 10 - Respostas ao item "Você já havia tido algum tipo de contato com a educação a distância, seja como aluno, tutor ou professor, antes de iniciar este curso?”

\begin{tabular}{l|r|r}
\hline \multicolumn{1}{c|}{ Resposta } & Número de alunos & Percentual \\
\hline Sim, com EaD baseada em materiais impressos. & 3 & $5 \%$ \\
Sim, com EaD telepresencial. & 21 & $32 \%$ \\
Sim, com EaD baseada em informática e ambientes virtuais. & 3 & $5 \%$ \\
Não, nunca. & 37 & $58 \%$ \\
\hline
\end{tabular}

A tabela 10 indica que um número nada desprezível de alunos já tiveram experiências anteriores com EaD telepresencial. É bem provável que a maioria destes alunos tenha sido cursista da Eadcon/Unitins, cuja presença no Tocantins era muito expressiva, e atuava especificamente com esta modalidade de educação a distância. A importância de destacar para os alunos as diferenças entre esta modalidade e a modalidade baseada em ambientes virtuais, como a que é utilizada nos cursos do sistema UAB, parece ainda maior diante dos números apresentados.

Tabela 11 - Respostas ao item "Distância aproximada de sua residência ao seu polo"

\begin{tabular}{l|rr}
\hline \multicolumn{1}{c|}{ Opção escolhida } & Número de alunos & Percentual \\
\hline Até $5 \mathrm{~km}$ / na mesma cidade. & 22 & $34 \%$ \\
De 6 a $50 \mathrm{~km}$. & 18 & $28 \%$ \\
De 51 a $100 \mathrm{~km}$. & 14 & $22 \%$ \\
De 101 a $200 \mathrm{~km}$. & 5 & $8 \%$ \\
Acima de $200 \mathrm{~km}$. & 5 & $8 \%$ \\
\hline
\end{tabular}

Pelos dados da tabela 11, vemos que a maioria dos alunos (84\%) mora a uma distância do polo equivalente ao máximo de uma hora de viagem. Fazendo o cruzamento dos dados expostos na tabela 11 na planilha original da pesquisa, vemos que não há relação entre o tamanho da cidade em que se encontra o polo e a distância da residência do aluno. Um exemplo é Cristalândia, onde os cursistas de Física são, na maioria, moradores de cidades a 
mais de $100 \mathrm{~km}$ do polo, enquanto os alunos de Química são, na maioria, moradores da própria cidade.

Tabela 12 - Respostas ao item "O que você pretende fazer após a conclusão do curso?"

\begin{tabular}{l|rr}
\hline \multicolumn{1}{c|}{ Opções escolhidas (permitida múltipla escolha) } & Número de alunos & Percentual \\
\hline Ingressar em curso de pós-graduação. & 59 & $92 \%$ \\
Continuar trabalhando somente. & 0 & $0 \%$ \\
Participar de grupos de estudos. & 6 & $9 \%$ \\
Trabalhar por conta própria ou abrir empresa. & 3 & $5 \%$ \\
Não tenho planos. & 2 & $3 \%$ \\
Tenho outro(s) plano(s). & 0 & $0 \%$ \\
\hline
\end{tabular}

A tabela 12 aponta a expectativa dos alunos quanto à continuação dos estudos. Este alto índice contrasta fortemente com a taxa de evasão observada nos cursos. Não há elementos que permitam obter uma conclusão definitiva sobre o fato. É possível que problemas com os cursos tenham levado à perda de expectativa de muitos quanto à própria conclusão da graduação. Também é possível que tenha havido um excesso de expectativa positiva nos alunos e um desprezo ou um desconhecimento em relação à dificuldade pedagógica e temporal derivada da realização de uma graduação na modalidade EaD. Outra possibilidade, ainda, é a de as respostas terem representado mais um sonho, presente no imaginário coletivo por representar, ainda que equivocadamente, o caminho obrigatório de quem quer ascensão profissional, do que representado um plano real para os alunos respondentes da pesquisa.

Tabela 13 - Respostas ao item "Quanto tempo você dedica aos estudos semanalmente?"

\begin{tabular}{l|rr}
\hline \multicolumn{1}{c|}{ Resposta } & Número de alunos & Percentual \\
\hline Menos de 2 horas. & 6 & $9 \%$ \\
De 2 horas a menos de 4 horas. & 22 & $34 \%$ \\
De 4 horas a menos de 8 horas. & 11 & $17 \%$ \\
De 8 horas a menos de 12 horas. & 10 & $16 \%$ \\
Pelo menos 12 horas. & 15 & $23 \%$ \\
\hline
\end{tabular}

A distribuição dos tempos mostrados na primeira coluna da tabela 13 foi proposta para que tivéssemos uma noção mais próxima da reduzida dedicação de carga horária por parte dos 
estudantes às tarefas propostas. Os cursos da UFT propõem a distribuição de uma carga horária de 180 horas ao longo de 9 semanas, o que compreende 20 horas semanais de estudos. No entanto, o que se observa pelas respostas dadas é uma baixíssima atribuição de tempo para os estudos. Mais de 3/4 dos estudantes declararam estudar menos de 12 horas semanais, tempo correspondente a $60 \%$ do esperado. Um total de $43 \%$ declara estudar menos de 4 horas, ou seja, menos de $20 \%$ do esperado. As altas taxas de reprovação observadas nas disciplinas do curso, especialmente nas disciplinas científicas e matemáticas básicas, talvez se devam a esta baixíssima dedicação ao estudo solitário. É uma conclusão compartilhada com a verificada no estudo de Brito, Gomes e Fernandes (2009). Tal problema é comum com o de outras iniciativas para a formação inicial e continuada de professores de Física e áreas afins, nas modalidades a distância e semipresenciais, como declara Angotti (2006):

\begin{abstract}
"Os resultados das avaliações parciais e finais não raro provocaram fortes tensões entre os matriculados das diversas áreas, docentes e administração. Quanto aos resultados do primeiro curso, de duração prorrogada para 18 meses, verificamos a necessidade de esforços conjuntos de "recuperação" de muitos dos inscritos, que tinham pouco tempo para se dedicarem aos estudos, previsto para um mínimo de 15 horas/semanais. Constatamos, no entanto, enorme empenho e determinação de ampla maioria dos professores/alunos." (p.144-145)
\end{abstract}

Tabela 14 - Respostas ao item "Qual a sua idade?"

\begin{tabular}{l|rr}
\hline \multicolumn{1}{c|}{ Opções escolhidas } & Número de alunos & Percentual \\
\hline Menos de 25 anos. & 9 & $14 \%$ \\
De 25 a 32 anos. & 28 & $44 \%$ \\
De 33 a 40 anos. & 17 & $27 \%$ \\
De 41 a 48 anos. & 6 & $9 \%$ \\
Mais de 48 anos. & 4 & $6 \%$ \\
\hline
\end{tabular}

Tabela 15 - Respostas ao item "Qual o seu estado civil?"

\begin{tabular}{l|rr}
\hline \multicolumn{1}{c|}{ Opções escolhidas } & Número de alunos & Percentual \\
\hline Solteiro(a). & 37 & $58 \%$ \\
Casado(a) ou equivalente. & 24 & $37 \%$ \\
Divorciado(a)/separado(a). & 3 & $5 \%$ \\
Viúvo(a). & 0 & $0 \%$ \\
\hline
\end{tabular}


Pelas tabelas 14 e 15, é possível traçar o perfil mediano do aluno dos cursos examinados: trata-se de alunos solteiros na faixa de 25 a 32 anos. O número de alunos casados ou mais velhos do que este perfil também é expressivo. É notável, embora comum na EaD, que apenas $14 \%$ dos alunos tenha menos de 25 anos.

Tabela 16 - Respostas ao item “Informações sobre mobilidade e interação informática."

\begin{tabular}{l|r|r}
\hline \multicolumn{1}{c|}{ Opções escolhidas (permitida múltipla escolha) } & Número de alunos & Percentual \\
\hline Possuo carro. & 21 & $33 \%$ \\
Possuo moto. & 20 & $31 \%$ \\
Possuo computador em casa. & 41 & $64 \%$ \\
Possuo acesso à internet por conexão discada em casa. & 7 & $11 \%$ \\
Possuo acesso à internet em cabo de banda larga em casa. & 20 & $31 \%$ \\
Possuo acesso à internet via rádio ou via satélite em casa. & 23 & $36 \%$ \\
\hline
\end{tabular}

Uma das preocupações derivadas do cruzamento das informações da tabela $11 \mathrm{com}$ as da tabela 16 é o fato de haver alunos que residem distantes do polo e não possuem acesso à internet em casa. Tais alunos conseguiram resolver estes problemas das mais variadas formas: adquirindo seu primeiro computador; utilizando computadores de locais públicos, como bibliotecas; solicitando a parentes ou amigos que baixassem o conteúdo da internet e o colocassem em um dispositivo armazenador, para que pudessem estudar desconectados. Houve, também, casos de alunos que não possuíam computador e desistiram do curso, por este ou por outros motivos.

Tabela 17 - Respostas obtidas para o item "Indique o aspecto peculiar da educação a distância baseada em tecnologias da informação e comunicação que, para você, teve o menor grau de dificuldade (a tarefa mais fácil)”

\begin{tabular}{lrrr}
\hline \multicolumn{1}{c|}{ Resposta } & Número de alunos & Percentual \\
\hline Trabalhar com o computador. & 42 & $66 \%$ \\
Gerenciar o tempo. & 8 & $12 \%$ \\
Debater adequadamente os temas das disciplinas. & 2 & $3 \%$ \\
Ler textos em lugar de ter um professor a explicar. & 2 & $3 \%$ \\
Expressar-me na forma escrita. & 10 & $16 \%$ \\
\hline
\end{tabular}


Tabela 18 - Respostas obtidas para o item "Indique o aspecto peculiar da educação a distância baseada em tecnologias da informação e comunicação que, para você, teve o maior grau de dificuldade (a tarefa mais difícil)”

\begin{tabular}{l|rr}
\hline \multicolumn{1}{c|}{ Resposta } & Número de alunos & Percentual \\
\hline Trabalhar com o computador. & 5 & $8 \%$ \\
Gerenciar o tempo. & 22 & $34 \%$ \\
Debater adequadamente os temas das disciplinas. & 14 & $22 \%$ \\
Ler textos em lugar de ter um professor a explicar. & 14 & $22 \%$ \\
Expressar-me na forma escrita. & 9 & $14 \%$ \\
\hline
\end{tabular}

Pelas tabelas 17 e 18, percebemos que o aspecto que menos gerou problemas ao processo ensino-aprendizagem foi o uso do computador, ferramenta essencial na EaD baseada em TIC. Esta informação contrasta com a opinião de alguns professores, especialmente os do primeiro semestre, obtida em conversas informais, sobre a baixa capacidade dos alunos de utilizar plenamente as ferramentas informáticas. Segundo eles, os alunos, em média, mantiveram muita dificuldade na interação com o computador no primeiro ano de curso. Esta dificuldade na interação com professores e tutores por TIC teria prejudicado o aprendizado dos componentes curriculares regulares, mesmo os que nada têm a ver com tecnologia.

Uma das possíveis razões para este descompasso é o fato de que muitos dos alunos respondentes do questionário já não são alunos do curso. Neste caso, teria havido evasão mais expressiva daqueles que têm mais familiaridade com as ferramentas informáticas. $\mathrm{O}$ fato de o questionário ter sido aplicado na forma digital também pode ter influenciado. Uma percepção subjetiva que tive em relação aos alunos que permanecem no curso, em relação a este aspecto, é o fato de que os aprendizes que permanecem matriculados não são os mais adaptados às exigências da $\mathrm{EaD}$, como a dedicação ao estudo solitário interativo, por exemplo, mas são os mais interessados em se formar.

Em relação ao item considerado mais difícil, houve uma maior distribuição das respostas, sendo que "gerenciar o tempo" já era uma preocupação logo no início do curso. Os alunos puderam, à medida que o curso teve andamento, aprender a gerenciar melhor o tempo, de forma que o índice de tarefas entregues fora do prazo, na comparação, para o curso de Química, entre as disciplinas "Matemática e Realidade" (do primeiro semestre, da qual fui tutor), "Física e Ambiente" (do segundo semestre, da qual fui professor) e "Sociedade, 
Cultura e História da Educação" (do terceiro semestre, da qual também fui professor), embora não tenha sido mensurado, é sensivelmente decrescente.

No caso do curso de Química, conseguimos obter a informação quantitativa sobre a evasão ao fim de 2010 por polo: em Gurupi, 3 alunos dos 25 matriculados já não participaram do curso de nivelamento de novembro e dezembro de 2010; em Cristalândia foram 4 alunos dos 24 matriculados; em Porto Nacional, um número alto: 12 ausências entre 25 alunos. São, portanto, parte dos alunos que não responderam ao questionário. $\mathrm{O}$ número mais expressivo de alunos evadidos em Porto Nacional se deve a uma junção de fatores: alunos de cidades maiores (com mais opções de cursos de graduação ou atividades profissionais, portanto) tendem mais à evasão. Trata-se de fato relatado também no Rio Grande do Norte e no Piauí. No caso de Porto Nacional, muitos alunos eram de Palmas, ou seja, tinham muitas opções na cidade de origem, sem ter de viajar com frequência para a cidade vizinha. Além disso, como já citei anteriormente, pesquisas apontam que um fator de evasão é já possuir grau de instrução equivalente. Este foi um caso comum entre os alunos de Porto Nacional, que já possuíam licenciatura em outras áreas.

No mês de abril de 2012, fizemos um novo levantamento sobre o número de alunos que efetivamente estavam participando das atividades do terceiro semestre. Apenas o curso de Química mostrou dados confiáveis. O resultado pode ser encontrado na tabela 19.

Tabela 19 - Número de alunos que frequentou regularmente o polo em abril de 2012

\begin{tabular}{|c|c|c|}
\hline Curso/Polo & Alunos presentes / matrículas iniciais & Percentual de evasão \\
\hline Química/Cristalândia & $10 / 24$ & $58 \%$ \\
\hline Química/Gurupi & $8 / 25$ & $68 \%$ \\
\hline Química/Porto Nacional & $6 / 25$ & $76 \%$ \\
\hline TOTAL & $24 / 74$ & $68 \%$ \\
\hline
\end{tabular}

Observando a tabela 19, podemos ser levados a crer que a taxa de evasão é extremamente elevada. No entanto, contextualizados os dados, percebemos que a taxa de evasão não foge da comumente registrada para cursos como estes. A própria Universidade de São Paulo, em seus cursos semipresenciais de formação de professores de ciências, registram evasão de cerca de $40 \%$ só no primeiro semestre (CURSO..., 2012). Os cursos de Biologia da UFT, também semipresenciais, registraram evasão que oscilou entre $60 \%$ e $80 \%$ na turma formada em 2011. A UFRN, segundo o entrevistado D, tem uma desistência girando em torno 
de $80 \%$ nos seus cursos de licenciatura em Física e em Química, proporção que o entrevistado assegura ser inferior à evasão dos cursos presenciais correspondentes naquela instituição. Por fim, em curso de complementação pedagógica oferecido semipresencialmente em convênio entre a Secretaria Estadual de Educação da Bahia e a UFSC, registrou-se evasão, em 18 meses, de 30\% no curso de formação de professores de Química e de 65\% no de Física (ANGOTTI, 2006).

A UFRN, ao contrário da UFT, já tem alunos formados. Segundo o entrevistado J, seu perfil mediano é o de alunos que já atuavam ou passaram a atuar como professores na rede pública e/ou particular. Alguns deles passaram a ser tutores dos cursos, tanto na Química quanto na Física. E há, ainda, o caso de um aluno egresso do curso de Física, anteriormente professor leigo, que conseguiu vaga no mestrado em Física na UFRN. Segundo o entrevistado J, em torno de 30 alunos concluíram o curso de Química ao fim do $1^{\circ}$ semestre de 2010, e mais 15 ao fim do $2^{\circ}$ semestre de 2010 , todos ingressantes em 2005, processo que teve a abertura de 60 vagas em 6 polos, totalizando 360 vagas. $O$ entrevistado G relatou a existência de 51 diplomados na Física, sendo que a maioria destes formandos já atuava como docente da educação básica no momento da formatura.

Apesar disso, os alunos da EaD, infelizmente, seguem sendo tratados institucionalmente como cidadãos de segunda classe. Os alunos da Sedis, diz o entrevistado $\mathrm{K}$, não se sentem alunos da UFRN, já que não têm acesso às mesmas bolsas e auxílios para permanência que os alunos presenciais. $\mathrm{O}$ entrevistado $\mathrm{K}$ chama a atenção sobre a falta de assistência ao aluno EaD: o Programa Nacional de Assistência Social ao Estudante, PNAS, por exemplo, não contempla a EaD. Da mesma forma, o Programa Institucional de Bolsas de Iniciação à Docência (Pibid) foi criado para ser exclusividade dos alunos de licenciaturas presenciais, sendo o acesso de alunos da EaD permitido apenas recentemente. Os alunos da UFT vivem situação similar. A maior taxa de evasão na $\mathrm{EaD}$ em relação à educação presencial se deve, em parte, a esta omissão.

\section{2. $\quad$ Os tutores}

Antes de falarmos sobre o papel dos tutores no sistema UAB, convém citar Masuda (2003), que diferencia a tutoria a distância, a que atua nas universidades, fisicamente longe dos alunos, mas próxima aos professores, da tutoria presencial, a qual é realizada nos polos regionais, em locais próximos aos estudantes e fisicamente distantes dos professores. $\mathrm{Na}$ 
regulamentação das bolsas do sistema $\mathrm{UAB}$, não há diferenciação entre a tutoria presencial e a tutoria a distância, de forma a flexibilizar o trabalho dos tutores. Diz a resolução 8/2010 do FNDE que cabe à instituição determinar, nos processos seletivos de tutoria, as atividades a serem desenvolvidas para a execução dos projetos pedagógicos, de acordo com as especificidades das áreas e dos cursos. Por exemplo: um polo que não possua tutor presencial pode ser servido por um tutor a distância de forma provisória enquanto uma nova seleção não se realiza ${ }^{22}$.

A UFRN adota o modelo de tutoria dupla, com tutores presenciais e tutores a distância, seguindo o modelo básico do sistema UAB. Na UFRN, predominam em número os tutores presenciais, que podem ser de três tipos: tutores orientadores (ou orientadores de estudos), tutores de laboratório e tutores de estágio. Cada polo tem um tutor de cada tipo, exceto polos que tenham poucos alunos. Este modelo de tutoria é padrão para a UFRN ${ }^{23}$, tendo sido definido ainda na época em que a $\mathrm{EaD}$ na instituição tinha um único colegiado. De acordo com o entrevistado D, este é o modelo da UFMT, de um tutor orientador no polo para todas as disciplinas ao longo de todo o curso, que tem sido seguido pela UFRN. Nas discussões sobre o modelo de tutoria a adotar, relata o entrevistado $\mathrm{M}$, o professor da área pedagógica apoiou o modelo da UFMT, mas os coordenadores da Física, da Química e da Matemática não concordaram. Assim, o modelo da UFMT teria sido adotado pela falta de outro $^{24}$.

O sistema de trabalho dos tutores na UFT, por outro lado, não teve qualquer tipo de alteração em relação à proposta original do sistema UAB. Isto significa que, ao contrário da UFPI, em que os tutores a distância viajam aos polos, especialmente àqueles em que não há tutores presenciais, e da UFRN, em que a maioria dos tutores é presencial, havendo três tutores presenciais especializados por polo, na UFT, a proporção de tutores presenciais e a distância, inicialmente, seguiu sendo de $50 \%$ para ambos, sendo os tutores a distância impedidos de viajar.

\footnotetext{
${ }^{22}$ De acordo com o que apurei no Piauí, tal situação é frequente naquele estado, visto que a UFPI seria exigente na seleção de tutores presenciais e nem sempre consegue um profissional substituto rapidamente, especialmente em polos mais isolados.

${ }^{23}$ No consórcio da UFRN com as universidades dos estados vizinhos, não cabia à universidade potiguar a formação dos primeiros tutores: isto ficou a cargo da UPE. No entanto, tal formação enfatizou a estrutura da educação a distância, tratando pouco, segundo o entrevistado D, da pedagogia do processo de tutoria e das dinâmicas de um ambiente virtual de aprendizagem.

${ }^{24}$ Segundo o entrevistado M, o consórcio Cederj, na pessoa de seu então presidente, Carlos Eduardo Bielschowsky, também contribuiu com o modelo de tutoria adotado na UFRN.
} 
A UFRN possuía, no início, uma coordenação geral de tutoria. O entrevistado $\mathrm{M}$ diz que os tutores precisam receber, sempre, orientações iguais, independentemente de pertencerem a cursos diferentes. Afinal, eles se comunicam entre si e, frequentemente, tutores de cursos distintos trabalham no mesmo polo. A exceção, segundo o entrevistado M, seria para tutores trabalhando em cursos muito diferentes. Daí a necessidade de centralizar o controle de tutoria. Para o entrevistado G, os tutores têm dificuldade de conhecer qual é o seu papel junto ao curso. Isto também pode ser atenuado com um controle mais centralizado de tutoria. $\mathrm{O}$ entrevistado $\mathrm{M}$ explica que o acompanhamento da coordenação geral de tutoria se dava com viagens realizadas até duas vezes por semestre a cada polo, e ao longo do período letivo a distância, por ferramentas de comunicação instantânea via internet, como o Skype, o que o entrevistado $\mathrm{M}$ entende como muito positivo.

No caso da UFT, o controle de tutores nunca foi centralizado e, de fato, os cursos examinados tiveram problemas, especialmente no polo de Cristalândia, que é o único que possui ambos os cursos, Física e Química. Orientações dos coordenadores de curso e dos coordenadores de tutoria, fisicamente mais distantes, foram, por vezes, ignoradas, em prol dos conselhos de quem estava mais próximo: o tutor do outro curso. Foi possível perceber que certas orientações e regras mais gerais sobre o trabalho dos tutores merecem ser discutidas entre as coordenações de tutoria e aplicadas uniformemente, ou o insistente reforço de que os projetos e formas de ação podem ser diferentes entre os cursos, cabendo ao tutor consultar a coordenação em caso de dúvidas.

O entrevistado D considera central a discussão sobre o papel do tutor presencial. Ele explica que os tutores, em geral, não gostam de ser meros repassadores de material: ao serem apresentados ao material didático, os tutores querem reestruturá-lo, remontá-lo, adaptá-lo. Opinião do entrevistado $\mathrm{M}$ é a de que o modelo de tutoria funcionou muito bem para as áreas pedagógicas, mas que não se mostrou adequado para as disciplinas específicas. Segundo ele, o tutor não gosta de dizer ao aluno que "não sabe" falar sobre ou explicar um determinado tema. Como em disciplinas pedagógicas é possível, mais facilmente, ter um domínio razoável e, até mesmo, fingir erudição, ao contrário das disciplinas de exatas, em que um domínio razoável é mais raro e fingir erudição é bem mais difícil, o sucesso dos tutores em atender satisfatoriamente (ou em simular atendimento de forma a dar segurança a) os alunos foi maior nas disciplinas pedagógicas.

Ou seja, os tutores presenciais se abstêm de sua missão como assistentes reais, e se frustram por não saber plenamente o conteúdo, ainda que não sejam os professores. Era isto o que o entrevistado G mencionava há pouco: os tutores têm dificuldade de conhecer qual é o 
seu papel junto ao curso. Lembremos, também, do relato do entrevistado $\mathrm{M}$, de que somente o professor da área pedagógica havia apoiado o modelo de tutoria da UFMT. Nota-se, aqui, uma coincidência de áreas: a opinião do entrevistado $\mathrm{M}$ é exatamente a de que somente os tutores pedagógicos deram certo. Talvez a oposição dos coordenadores das áreas científicas ao modelo de tutoria fosse uma previsão de que o modelo de tutoria proposto não funcionaria nessas áreas. Neste caso, ainda é necessário pensar em soluções: mudar o modelo de tutoria, mudar o perfil de tutores ou propor alterações no treinamento e na capacitação específica de tutores presenciais nas áreas científicas. Para discutir tais possibilidades, convém examiná-las um pouco mais de perto. Farei isto sem rigor na linearidade, mas buscando elementos pertinentes, até por não ter sido verificada, na UFT, problemas com os tutores presenciais no sentido apontado aqui ${ }^{25}$.

A seleção de tutores, segundo o entrevistado J, compreende análise de currículo e entrevistas. Atualmente, o perfil de tutor orientador como um profissional que atua em sala de aula e tem formação na área de Química tem sido muito mais fácil de encontrar e de exigir, afirma o entrevistado J, embora, inicialmente, houvesse baixa oferta de tutores com graduação em Química, sendo frequente que estes tivessem formação em Matemática, bem mais comum no interior do Nordeste. O mesmo não se verifica no curso de Física, onde, segundo o entrevistado $\mathrm{G}$, nem $50 \%$ dos tutores têm formação em Física. Isto não deveria ser uma preocupação de maior grandeza, afinal, na UFRN, o tutor orientador não tem a obrigação de eliminar dúvidas de conteúdo. No entanto, a "tentação" de ministrar aulas era grande. Segundo o entrevistado M, vários tutores tentaram ministrar "aulões", principalmente na área de matemática, mas a prática não foi recomendada. Ou seja, os problemas estão, mesmo, na falta de posicionamento adequado dos tutores orientadores presenciais quanto ao seu papel. Ainda assim, afirma o entrevistado J, os tutores fazem "oficinas" de matemática, buscando incentivar os alunos a estudar a matéria, especialmente a disciplina de Cálculo, que, segundo ele, é uma das que possui os mais altos índices de reprovação.

Notemos, no entanto, que a nota final de qualquer aluno da EaD na UFRN, em cada componente curricular, é composta, em peso de $80 \%$, pela nota dada pelo professor da disciplina, enquanto os outros $20 \%$ são atribuídos exclusivamente pelo tutor orientador, sem

\footnotetext{
${ }^{25}$ Uma das impressões que eu havia trazido do Piauí era a necessidade de realizar treinamentos com os tutores presenciais, e não somente com os tutores a distância, mais próximos das coordenações de curso. Mesmo não conseguindo realizar tais capacitações localmente, especialmente devido à restrição orçamentária em diárias, a coordenação do curso de Química da UFT, em especial, com o apoio dos coordenadores de polo, buscou garantir que os tutores presenciais passassem a atender a objetivos mínimos, considerados mais importantes. Um único caso mais grave foi percebido, sem relação com o que estamos discutindo aqui: permissividade de um tutor em relação à consulta fraudulenta a livros no momento da aplicação das avaliações presenciais.
} 
influência de qualquer outro ator. Para o entrevistado D, isto mostra uma clara ambiguidade no atual sistema da UFRN: ao mesmo tempo em que se pretende vetar as possibilidades de o tutor orientador ministrar aulas, dá-se a ele o poder e a responsabilidade de avaliar os alunos. É possível, portanto, que derive daí parte dos problemas de "identidade" e de função do tutor. Ao mesmo tempo em que a sua participação na avaliação permite a valorização do seu papel, essa atividade acaba transbordando para áreas em que não se deseja que o tutor atue.

Há, ainda, outra questão: para orientar o trabalho de avaliação executado pelo tutor, a UFRN criou uma complexa ficha de orientação de avaliação, versando sobre aspectos diversos, externos ao conteúdo curricular, como a assiduidade do aluno ao polo, por exemplo. No entanto, para o entrevistado M, um grande problema persiste, já que todos os tutores dão a nota máxima a todos os alunos, exceto em casos muito específicos. Isto possivelmente ocorre pela proximidade criada entre aluno e tutor, que é pedagogicamente positiva, mas é causa maior das distorções na avaliação. Apesar de todos os problemas, o entrevistado $\mathrm{M}$ se coloca contra tirar do tutor presencial o poder de atribuir $20 \%$ da nota final do aluno.

A UFT sequer aventou a possibilidade de atribuir ao tutor presencial o poder de avaliação. Os tutores presenciais têm um papel apenas indireto na avaliação dos alunos: consultados, informam sobre a frequência e a dedicação de certo aluno, recebem e encaminham pedidos de avaliação fora do prazo, entre outras funções, mas não são responsáveis, como na UFRN, por suas matrículas ${ }^{26}$ nem por atribuir parte da nota de cada componente curricular. Nota-se, por contraste, que, se, na UFT, o tutor presencial se esvazia de importância acadêmica estrita, por outro, ele pode se dedicar com mais afinco a atividades como incentivar a formação de grupos de estudo entre os alunos e o estudo solitário; organizar os momentos presenciais; buscar reduzir fatores de evasão que estejam associados à instituição ou a aspectos acadêmicos. Segundo o entrevistado C, são tutores indispensáveis, que mereceriam uma bolsa mais generosa dentro do sistema $\mathrm{UAB}$, diante do enorme trabalho que executam ${ }^{27}$.

Segundo o entrevistado M, não é frequente a interação entre os tutores presenciais e os professores das disciplinas. Problema similar relatado pelo entrevistado G é o de que os tutores presenciais não dão retorno sobre o cotidiano de estudos e eventuais dificuldades

\footnotetext{
${ }^{26}$ Até o primeiro semestre de 2011, os tutores presenciais da UFRN eram os responsáveis por efetuar a matrícula semestral dos alunos em cada polo. Isto gerava muitos problemas, que não discutirei aqui. A partir do segundo semestre de 2011, as matrículas passaram a ser feitas pelos próprios alunos, via internet.

${ }^{27}$ Até agosto de 2012, não existia nenhuma previsão sobre o eventual papel que os tutores desempenharão na condução e no controle dos estágios curriculares, tanto na Física quanto na Química, embora o início do período previsto para estágios já se aproximasse.
} 
encontradas aos professores das disciplinas. De fato, uma melhor comunicação entre os atores poderia, não somente na UFRN, como também na UFT, levar a uma melhor qualidade de ensino. Minha experiência como professor na $\mathrm{EaD}$ deixou isto muito claro: confissões e críticas dos alunos em relação ao trabalho do professor eram feitas ao tutor presencial, e não diretamente ao professor. A relação entre professor e alunos, especialmente quanto ao contrato didático, poderia ser melhor se o tutor presencial repassasse as falas dos alunos ao professor; obviamente, respeitando-se o preceito ético de não identificar os alunos quando não fosse estritamente necessário.

O entrevistado B é especialmente crítico ao trabalho dos tutores presenciais. Diz que, em geral, fazem apenas o mínimo ${ }^{28}$; os tutores de laboratório seriam pouco afeitos à comunicação com os professores das disciplinas; em geral, os tutores seriam "ariscos", "arredios" no trato com a coordenação do curso e com os professores; certas omissões dos tutores teriam sido críticas para o andamento regular dos cursos.

A experiência da UFPI sugeriu que seria importante e adequado elaborar um termo de compromisso para os tutores na UFT, dada a existência de críticas ao trabalho dos mesmos, também naquela universidade. No entanto, tal documento nunca foi elaborado, não tendo feito falta, ao menos durante estes primeiros 18 meses. Nenhum dos entrevistados soube dizer, ao certo, quais as razões pelas quais a UFT teve poucos problemas com os tutores, mas isto pode ter relação com uma postura mais presente das coordenações de curso, de tutoria e, especialmente, de polo. No Tocantins, os coordenadores de curso e de tutoria cuidam de menos tutores, pois os cursos têm muito menos alunos. Por fim, como os polos do Tocantins são menores e possuem menos cursos, em média, do que os polos em que a UFRN atua, também haveria mais disponibilidade dos coordenadores de polo para acompanhar o trabalho dos tutores presenciais e, até mesmo, auxiliá-los em algumas tarefas. Os tutores da UFT vêm sendo destacados como o ponto forte da sustentação dos cursos, de acordo com declaração do entrevistado C, o que confirma sua importância para o bom andamento dos processos pedagógicos e administrativos da $\mathrm{EaD}^{29}$.

\footnotetext{
${ }^{28} \mathrm{Na}$ UFRN, da carga horária semanal de 20 horas, os tutores presenciais devem dedicar 16 horas presenciais no polo e 4 horas para planejamento de atividades. Na UFT, não havia regra até o início de 2012, quando se estabeleceu uma distribuição de 12 horas e 8 horas, respectivamente à presença no polo e ao planejamento de atividades.

${ }^{29}$ O mesmo não tem sido verificado em cursos de especialização, aperfeiçoamento e extensão da própria UFT. A reclamação de coordenadores de curso e de polo é muito frequente, tendo sido proposto, inclusive, um controle eletrônico de ponto. $\mathrm{O}$ fato de estes cursos estarem instalados em um número muito maior de polos, especialmente por não depender da existência de laboratórios didáticos, e, portanto, haver um número muito maior de tutores a gerenciar, apenas corrobora a nossa hipótese.
} 
Segundo os entrevistados $\mathrm{G}$ e $\mathrm{J}$, à medida que os alunos se habituam ao sistema de estudo solitário com interação virtual, assim como a evasão vai eliminando aqueles alunos que não se adaptam às características da modalidade, os tutores orientadores de estudos passam a ser menos procurados. Em outras palavras, o tutor menos importante na fase final do curso é o orientador de estudos, pois o aluno médio vai adquirindo autonomia e deixa de demandar orientação de estudos com tanta frequência. Desta forma, quando o número de alunos em um polo da UFRN não permite mais a manutenção de três tutores, o primeiro a ser dispensado é o tutor orientador, enquanto o tutor de estágio assume as suas funções. De fato, com a redução do número de alunos em polos de fora do Rio Grande do Norte, as coordenações de curso vêm tendo de reduzir o número de tutores presenciais desses polos. O polo de Tabira (PE), por exemplo, já possuía, em abril de 2011, apenas dois tutores para o curso de Física, o de estágio e o de laboratório, que se prestavam, também, a ser orientadores de estudo. Surubim (PE) só ficou com um tutor de Física. O entrevistado G relatou uma proposta de, no futuro, adaptar a tutoria de estágio à tutoria orientadora, para que fiquem reunidas a cargo de um só profissional.

Ao contrário dos tutores orientadores, os tutores de laboratório da UFRN precisam ser pós-graduandos ou pós-graduados na área, visto que esta é a tutoria que mais depende de um bom domínio da Física e da Química como ciências experimentais, de acordo com o entrevistado J. Nos polos em que este tutor não consegue ser selecionado, um tutor da capital Natal viaja ao polo para realizar a preparação dos experimentos. Na visão do entrevistado J, para o curso de Química, na atual estrutura de tutoria, o tutor de laboratório fica sobrecarregado, já que são muitas as disciplinas experimentais, de diversos períodos, sendo ministradas simultaneamente.

Os tutores a distância da UFT, por outro lado, nunca viajam. Sua tarefa é a de acompanhar os alunos no Moodle, eventualmente corrigindo atividades secundárias propostas pelos professores das disciplinas e organizando planilhas pertinentes aos cursos, como as que se referem a notas. Ou seja, os tutores a distância, estes, sim, ficam parcialmente responsáveis por atribuir notas aos alunos, embora a nota atribuída pelo tutor restrinja-se ao próprio conteúdo curricular, bem como fique a critério do professor da disciplina atribuir ou não a função de correção de atividades ao tutor EaD. Alguns dos tutores a distância do curso de Química, por falta de exigência do edital de seleção, não residiam em Gurupi, cidade onde se encontra a coordenação do curso. Trata-se de uma situação que não encontra paralelo com os relatos obtidos no Piauí e no Rio Grande do Norte, tampouco no curso de Física da UFT. Na visão do entrevistado $\mathrm{C}$, não há, de fato, a necessidade de contato presencial entre o tutor a 
distância e o professor da disciplina, desde que os profissionais se adaptem ao método de trabalho e de operação da EaD, especialmente fazendo uso pleno das ferramentas de comunicação a distância.

Os tutores a distância são pouco utilizados pela UFRN. Segundo o entrevistado J, para que uma disciplina faça jus a um tutor a distância no curso de Química ela precisa ter, no mínimo, 100 alunos matriculados, se for uma disciplina teórica, ou 50 alunos, no caso de uma disciplina prática. É exigido, na UFRN, que os tutores a distância morem em Natal ou na região metropolitana, para que possam ser convocados pelos professores de disciplina. Estes tutores, segundo o entrevistado $\mathrm{J}$, precisam entender de $\mathrm{EaD}$ e de internet, além de, obrigatoriamente, ter formação na área da disciplina em que atuam, complementa o entrevistado D. Por esta razão, recebem dois treinamentos: um treinamento técnico e um treinamento pedagógico. Ainda que os tutores sejam remunerados, há, segundo o entrevistado J, a figura do tutor voluntário, cujo trabalho é considerado como iniciação a docência. Ao fim do seu trabalho, o tutor voluntário recebe um certificado.

A ideia de haver, na UFT, mais tutores presenciais do que tutores a distância, como ocorre na UFRN, foi uma bandeira que eu, especialmente, levantei junto à coordenação do curso de Química. Eu atuei como tutor a distância em três disciplinas daquele curso e praticamente não tive retorno dos alunos no ambiente virtual, apesar de insistentes tentativas, o que levava a crer que era mais importante para o curso ter mais tutores presenciais. Tornou-se inevitável dispensar tutores a distância quando os cursos sofreram evasão, entre 2011 e 2012, e o número de alunos efetivamente matriculados caiu.

Esta redução de bolsas para os cursos impactou mais intensamente no curso de Química, onde há uma preocupação especial com a evasão dos alunos. A coordenação do curso passou a levar em consideração muito mais intensamente o apreço dos alunos por determinados professores para mantê-los no curso, ainda que à custa, em certos casos, de uma redução da qualificação e da qualidade do ensino oferecido, visando a agradar os alunos e evitar a evasão, para que fossem mantidos o número de tutores e a previsão anual de verbas. Considero este fato grave, mas cuja responsabilidade não deve ser atribuída somente à postura da coordenação do curso. Ao contrário, trata-se de uma resposta a uma política equivocada, mais preocupada com eficiência numérica do que com eficácia formativa, que caracteriza iniciativas centrais de fomento, como é o caso do sistema UAB. A resposta dada pela coordenação do curso é a esperada por quem vê números, mas não vê qualidade, o que parece ser regra no sistema: como o efeito do corte de verbas é sentido em curto prazo, enquanto a 
baixa qualidade da formação só será sentido em longo prazo, a opção é pela garantia de regularidade no fluxo financeiro.

Esta instabilidade é inerente à atual estrutura do sistema UAB, e me parece claro, ao vivenciar um exemplo de situação de falta de garantias para a manutenção do curso, que enquanto a UAB não se transformar em um programa de regras claras e estáveis, deixando de ser obra de governo para ser uma instituição de Estado, não é possível garantir qualidade da educação pública a distância. $\mathrm{O}$ entrevistado $\mathrm{C}$ concorda que a $\mathrm{EaD}$ deva ter os mesmos critérios de estabilidade que os cursos presenciais, e que a variação do local de oferta a cada novo vestibular não deva significar variação de previsão de verbas nem abandono dos polos das ofertas anteriores, como vem sendo a regra.

A crítica concorda com Alonso (2010), que mostra que o financiamento dos cursos é restrito aos anos de sua integralização, desrespeitando os ritmos de aprendizagem dos alunos. Por conta disso, os processos seletivos para os cursos a distância não obedecem à mesma periodicidade das seleções para os cursos presenciais. Como os critérios e condições de abertura de novas turmas, bem como a disponibilidade orçamentária para isto, variam muito expressivamente de ano para ano, não há um fluxo regular de ingressantes na universidade, o que torna a realização de disciplinas em regime de dependência, por exemplo, muito mais complexa.

A dificuldade de se conseguir tutores em quantidade e qualidade também passa pela questão da remuneração. $\mathrm{O}$ entrevistado $\mathrm{K}$ enxerga o vínculo dos tutores no sistema UAB como bolsistas como uma bomba prestes a explodir. Uma vez que existem tutores bolsistas por 8 anos consecutivos, considerando-se os diversos programas de formação de professores do MEC no período, o entrevistado $\mathrm{K}$ entende que problemas trabalhistas possam advir deste vínculo prolongado. Quando questionado sobre o fato de os tutores não terem direitos trabalhistas, o ex-secretário de Educação a Distância do MEC, Carlos Eduardo Bielschowsky, disse no $1^{\circ}$ Encontro Nacional de Tutores, ocorrido na Universidade Estadual de Campinas (Unicamp) em 21 de março de 2011, que lamentava o fato, mas que não havia dispositivo legal que permitisse a contratação temporária para o serviço público no âmbito do Sistema $\mathrm{UAB}$, ao contrário do que ocorre nas universidades tradicionais, cuja legislação prevê a contratação de professores substitutos. Aparentemente, trata-se mais de um pretexto do que de uma justificativa, pois se fosse do interesse do poder público, tais dispositivos poderiam ser incluídos na legislação. Outra observação que refuta a colocação do ex-secretário é o precedente da contratação dos orientadores acadêmicos, o que mostra a possibilidade real de contratação temporária no âmbito do MEC. Outra situação grave refere-se ao atraso frequente 
com relação ao dia do pagamento. A passagem da responsabilidade deste pagamento do FNDE para a Capes, ocorrida em meados de 2011, não trouxe alteração positiva neste panorama.

\subsection{Professores e coordenadores}

Depois de traçar um perfil de alunos e tutores, busco identificar as características dos demais atores do sistema: coordenadores UAB, de curso e de polo, professores e orientadores acadêmicos. Uma das coisas que mais chama a atenção na determinação do perfil destes profissionais é o fato de que, mesmo que muitos não tenham tido qualquer experiência anterior com EaD, ou mesmo com educação, pelas regras do sistema UAB e de suas bolsas, eles estão perfeitamente aptos a ocupar suas funções. Em geral, tais regras preveem que o professor tenha formação pós-graduada e três anos de experiência na docência de nível superior, ou, caso tenha experiência entre 1 ano completo e 3 anos incompletos, que mantenha-se habilitado à função, embora perceba remuneração menor. Ou seja, de nenhum dos profissionais do sistema $\mathrm{UAB}$, coordenadores, professores e orientadores acadêmicos, se exige que tenha experiência em $\mathrm{EaD}$, tampouco que participem de capacitações.

De fato, o treinamento dos professores é um ponto crítico em ambas as universidades. Os entrevistados J e K afirmam que há treinamentos semestrais em $\mathrm{EaD}$ ofertados pela Sedis, obrigatórios para os tutores, mas que são poucos os professores que leem sobre o tema ou se interessam por participar das referidas oficinas, especialmente os professores mais antigos da instituição, o que prejudica a renovação dos quadros de professores. $\mathrm{O}$ entrevistado $\mathrm{K}$ traz a informação que ilustra tal desinteresse: em um curso sobre TIC ofertado internamente pela Sedis, houve cerca de 150 docentes interessados nas 50 vagas ofertadas, o que representa menos de $10 \%$ do quadro docente da UFRN. O entrevistado $\mathrm{G}$ entende que, até hoje, os professores não interagem o suficiente; ou seja, não entram unidos na $\mathrm{EaD}$, ainda que participem de capacitação para este trabalho. Para o entrevistado $\mathrm{M}$, é muito difícil mudar a cabeça do professor, especialmente o universitário. Na UFT, em outubro de 2009, o CNTE (atual DTE) promoveu uma oficina de 20 horas para capacitação com os futuros professores dos cursos, bem como para os demais professores interessados. Responsabilizaram-se pela oficina duas professoras ligadas ao consórcio Cederj. A ênfase do curso foi dada à confecção de materiais didáticos, especialmente enfatizando a conversão do material bruto entregue pelos especialistas das universidades em um material que possa, de fato, ser utilizado pelo 
aluno de forma autônoma. Depois disso, nunca mais houve capacitações a professores com profissionais externos à UFT. As capacitações internas, oferecidas sem regularidade, insistentemente, mantinham o vício de se preocupar com as teorias pedagógicas da EaD e com as ferramentas e funcionalidades do Moodle, sem tratar dos aspectos práticos da interação professor-aluno. A exceção foi a última capacitação, oferecida em fins de 2011. Seja como for, é preocupante que os professores não se interessem pelas capacitações e, também, estas sejam ofertadas com qualidade abaixo da razoável, já que se torna ainda mais difícil esperar uma postura crítica e dialógica dos envolvidos, especialmente quanto ao conhecimento e à ação de acordo com o que prevê o projeto pedagógico dos cursos.

Embora não houvesse a necessidade de uma capacitação formal, uma dificuldade encontrada na época da implantação da EaD na UFRN, segundo o entrevistado B, foi a de encontrar professores para o curso. Apesar da oferta de bolsas tanto para o professor conteudista quanto para o professor de disciplina - que, na grande maioria dos casos, eram os mesmos na primeira oferta das disciplinas - os professores dos departamentos tradicionais se mostravam refratários à ideia de assumir o trabalho. Atualmente, a situação já é diferente, e os professores da UFRN precisam ser selecionados. Segundo o entrevistado J, há uma preferência, na seleção, por professores que tenham sido autores do material didático que será aplicado. Os cursos costumam manter o quadro de professores, fazendo a substituição apenas quando necessário ou solicitado pelo professor. Quando uma disciplina não é aceita por nenhum professor do quadro da UFRN, abre-se um edital de seleção externa. Aos professores que nunca trabalharam com $\mathrm{EaD}$ costuma ser atribuída uma única disciplina ou pequeno conjunto de disciplinas, de forma que a coordenação possa verificar a qualificação e a habilidade daquele professor para ministrar disciplinas na modalidade a distância, segundo o entrevistado J. Este entrevistado afirma, também, acompanhar os professores ao longo do semestre, apoiando-lhes, tirando-lhes as dúvidas didáticas e pedagógicas características da $\mathrm{EaD}$ que possam surgir, bem como solucionando problemas típicos de coordenação de curso.

Na UFT, a postura das coordenações dos cursos em relação à escolha dos professores é bastante distinta da UFRN e mesmo entre os dois cursos. Na UFRN, ao observar o conjunto de materiais didáticos elaborados e, consequentemente, grande parte dos professores que aplicaram as disciplinas nos cursos, raramente se observa um nome se repetir em mais de uma disciplina. Caso diametralmente oposto ao observado no curso de Física da UFT, em que, nas listas dos cinco professores do primeiro e do segundo semestre, apenas um nome não se repetiu. Na Química, embora houvesse maior alternância de professores, ainda assim alguns 
nomes tenderam a se repetir, como o caso do professor que ministrou duas disciplinas no mesmo semestre.

Alguns professores da EaD são natos, não fazendo parte de qualquer seleção. Explica-se: o governo federal criou, já a partir dos editais de chamada pública para o sistema UAB, vagas docentes nas universidades que haviam aderido ao projeto. Tratava-se, portanto, de vagas cuja exigência era a de atuação docente obrigatoriamente vinculada à EaD. Na UFRN, todas estas vagas docentes foram vinculadas à Sedis. No primeiro semestre de 2011, havia um processo em andamento para vincular os docentes ao departamento com que tivessem mais afinidade (Física, Química, Educação ou outro). A maioria dos professores optou pelo departamento da ciência básica, evitando o Departamento de Educação. Na UFT, tais professores também foram obrigados, ao ingressar na universidade, a se vincular ao colegiado de um dos cursos presenciais do campus onde estivessem lotados. Há, por exemplo, um professor de vaga EaD vinculado ao colegiado do curso de Agronomia. Uma crítica comum dos entrevistados $\mathrm{G}$ e $\mathrm{J}$ é a flexibilização do perfil das vagas docentes de EaD na UFRN. No caso da Química, informou o entrevistado J, das duas vagas destinadas ao curso, a primeira incluiu, no concurso, a cobrança de temas da área de ensino de Química, o que não ocorreu no segundo concurso. No caso da Física, alega o entrevistado G, o fato de a segunda vaga ter a condução do processo de seleção atribuída ao departamento de Física e não mais à Sedis levou a uma condição semelhante.

Tanto na UFRN quanto na UFT, o trabalho docente na EaD foi regulamentado, sendo que, nesta última, apenas em 2011. Na UFRN, os professores natos da $\mathrm{EaD}$ não podem receber bolsas do sistema, restrição inexistente na UFT. No entanto, em ambas as instituições, o tempo dedicado à EaD é considerado para fins institucionais ou funcionais, como para progressão funcional e estágio probatório. Isto facilitou, por exemplo, aos coordenadores de curso da UFT que conseguissem convencer professores a ministrar disciplinas em $\mathrm{EaD}$ sem perceber bolsas.

Ao buscar traçar um perfil dos professores da UFRN, busquei para a análise o nome dos 25 professores que elaboraram os materiais didáticos dos primeiros dois semestres dos dois cursos, visto que, exceto em casos pontuais, os mesmos professores ministraram as respectivas disciplinas, ao menos na primeira oferta de cada componente curricular. A restrição dos dois primeiros semestres se deu para que fosse justa a comparação com o perfil dos 14 professores do Tocantins, pois, neste caso, também restringi a busca do perfil aos dois primeiros semestres. Apenas 23 dos 25 professores da UFRN possuem currículo Lattes, enquanto todos os docentes da UFT têm o seu. Tomei como padrão de análise o currículo do 
professor da UFRN à época em que compôs o material didático, ou seja, fins de 2005, enquanto o perfil dos docentes da UFT refere-se à época em que ministraram a disciplina, ou seja, 2011. Por fim, busquei, no currículo dos profissionais, experiência anterior às referidas épocas padrão com a área de formação de professores ou, ainda, alguma produção acadêmica na área de Educação. O resultado pode ser observado nas tabelas 20 e 21, abaixo.

Tabela 20 - Perfil de titulação dos docentes dos cursos pesquisados na UFRN e na UFT

\begin{tabular}{l|r|r}
\hline \multicolumn{1}{c|}{ Maior titulação } & UFRN, número e proporção & UFT, número e proporção \\
\hline Pós-doutorado & $2 / 23(9 \%)$ & $0 / 14(0 \%)$ \\
Doutorado & $19 / 23(78 \%)$ & $5 / 14(36 \%)$ \\
Mestrado & $2 / 23(9 \%)$ & $8 / 14(57 \%)$ \\
Especialização & $0 / 23(0 \%)$ & $1 / 14(7 \%)$ \\
\hline
\end{tabular}

Tabela 21 - Perfil de graduação dos docentes dos cursos pesquisados na UFRN e na UFT

\begin{tabular}{lrr}
\hline \multicolumn{1}{c|}{ Título } & UFRN, número e proporção & UFT, número e proporção \\
\hline Bacharel & $14 / 23(61 \%)$ & $7 / 14(50 \%)$ \\
Licenciado & $10 / 23(43 \%)$ & $8 / 14(57 \%)$ \\
Experiência ou produção na área & $13 / 23(57 \%)$ & $5 / 14(36 \%)$ \\
\hline
\end{tabular}

A análise do perfil dos professores atuantes ${ }^{30}$ na UFT mostra uma baixa experiência anterior com educação: apenas cinco dos 14 professores dos dois primeiros semestres tinham tal experiência, o que dá 36\%. Número bem diferente do observado na UFRN: $57 \%$ dos professores que escreveram apostilas das disciplinas do primeiro ano já tinham trabalhado na área pedagógica ou publicado artigos na área de educação ou de ensino de ciências. Por outro lado, a proporção de licenciados é maior na UFT: 57\%, ante $43 \%$ na UFRN.

Quanto ao perfil dos coordenadores UAB, até julho de 2012, ambas as universidades só haviam tido dois ocupantes no cargo cada uma. Na UFT, o perfil dos dois é parecido, no sentido de terem razoável experiência administrativa e de gestão em geral, mas de não possuírem experiência significativa prévia com educação e gestão educacional, especialmente

\footnotetext{
${ }^{30}$ Dois dos 14 professores da UFT não faziam parte dos quadros da instituição, sendo docentes de outras IES do estado (embora não da Unitins). Assim, em todos os pontos desta tese, mesmo quando digo "professores da UFT", refiro-me aos professores que atuaram nos cursos EaD da UFT, mesmo sabendo que nem todos possuíam vínculo contratual com a instituição, sendo, meramente, bolsistas UAB.
} 
$\mathrm{EaD}$ e gestão da $\mathrm{EaD}$. A UFRN, por outro lado, teve dois coordenadores UAB no período de 2003 até 2012. Ambos têm experiência com educação e doutorado na área, bem como experiências anteriores em gestão educacional. Portanto, são possuidores de um perfil acadêmico e de experiência profissional contrastante com o perfil dos coordenadores UAB no âmbito da UFT.

Os coordenadores de polo são selecionados pelo mantenedor do polo, seja o governo municipal, estadual ou, excepcionalmente em certos polos do Rio Grande do Norte, pela UFRN. Os coordenadores de polo são bem tratados pela Sedis, segundo o entrevistado M, havendo uma reunião semestral com estes coordenadores em Natal; além disso, quando há problemas, um representante da Sedis vai ao polo para buscar solucioná-los. Na UFT, a relação varia: em alguns polos, é extremamente positiva; em outros, é engessada. Ainda assim, quando chamados a participar do processo na UFT, em reuniões na DTE, por exemplo, têm contribuído muito positivamente, graças à sua experiência teórica e prática em EaD, para a evolução da gestão dos cursos desta modalidade na universidade. Os coordenadores de polo, apesar do enorme esforço de fazer muito com pouco, transmitem aos cursos os problemas derivados do desleixo com que a EaD é tratada no âmbito do governo estadual. A falta de funcionários, móveis, área física e suprimentos em quantidade e qualidade suficientes é a ponta de um iceberg de problemas.

A consulta dos perfis dos coordenadores e ex-coordenadores de curso da UFT na Plataforma Lattes mostra que nenhum deles possui graduação equivalente à dos cursos que coordenam. No caso da Física, foram dois os coordenadores, ambos licenciados, mas em Matemática; na Química, o coordenador possui bacharelado, não tendo formação pedagógica em nível superior. Na UFRN, há dois ex-coordenadores e dois coordenadores. Os primeiros envolveram-se com alguns projetos na área de educação durante a docência universitária, mas, em seus currículos, não consta formação na área. Já os últimos têm produção e projetos de pesquisa na área de Ensino de Ciências. O perfil dos novos coordenadores de curso da UFRN é, portanto, de viés mais pedagógico do que o perfil dos ex-coordenadores.

Até o primeiro semestre de 2011, os colegiados de curso da UFRN e da UFT seguiam sendo informais, ou seja, representados por professores indicados diretamente pelo coordenador de curso, sem institucionalização. O entrevistado J afirma que fazem parte do colegiado professores que ministram disciplinas na $\mathrm{EaD}$, mas não todos: somente aqueles que têm mais afinidade com a área de ensino de Ciências.

A licenciatura em Química da UFT possui, também, um Núcleo Docente Estruturante (NDE). Ao contrário do que se observa nos cursos examinados da UFRN e nos cursos 
presenciais da UFT, o NDE e o colegiado de curso contam com os mesmos professores, embora ambos tenham atribuições diferentes. A coordenação do curso vem buscando incluir os professores de cada semestre nas reuniões do colegiado de curso, enquanto mantém as reuniões do NDE mais restritas, exclusivas aos professores mais ligados ao curso. Na UFRN, no entanto, de acordo com o entrevistado J, é o NDE o fórum de discussão do qual os professores que estão apenas em passagem pela $\mathrm{EaD}$ são convidados a participar, e não o colegiado de curso. Trata-se, no entanto, de situação oposta à pensada pela Comissão Nacional de Avaliação da Educação Superior, que instituiu o NDE nos cursos brasileiros. O curso de Física da UFT, até julho de 2012, não possuía NDE oficialmente constituído.

Note-se que a seleção dos componentes dos colegiados do curso e do NDE são realizadas integralmente pelos respectivos coordenadores do curso. Trata-se de uma prerrogativa antidemocrática dentro da universidade pública. A própria seleção de coordenadores de curso, realizada pela coordenação UAB, também é realizada sem que haja uma concorrência aberta, ao contrário do que ocorre com as coordenações dos cursos presenciais. Isto faz com que as coordenações dos cursos $\mathrm{EaD}$, cargos não somente com certo prestígio e influência dentro da universidade, mas com remuneração específica dada pela respectiva bolsa $\mathrm{UAB}$, sejam alvo de disputas políticas.

\subsection{Orientadores acadêmicos}

Uma particularidade dos cursos da UFT é o fato de ser uma das universidades contempladas, em 2009, com profissionais contratados temporariamente e cedidos pelo MEC, com formação mínima de mestrado na área da ciência básica e/ou em ensino de ciências, para atuar no apoio à EaD junto aos polos de apoio presencial e, também, junto às coordenações dos cursos. O edital 1/2009, de 2 de junho de 2009, estabeleceu as normas do processo seletivo simplificado destes profissionais, denominados "orientadores acadêmicos" (OA), para 96 vagas nos estados do Amapá, do Amazonas, do Maranhão, do Pará, do Piauí, de Rondônia e do Tocantins, nas áreas de Matemática, Física, Química e Biologia. Na implantação dos cursos tocantinenses, os OA tiveram um papel que merece ser avaliado.

Uma das principais dificuldades verificadas na implantação de cursos a distância em localidades de difícil acesso é garantir a presença dos professores de disciplina nos momentos presenciais. A Seed buscou superar esta dificuldade selecionando OA para atuação nos polos mais isolados, buscando garantir a presença permanente de quadros qualificados nestes locais. 
A seleção foi realizada nacionalmente em agosto de 2009 e as contratações ocorreram em outubro e novembro do mesmo ano por vínculos temporários anuais com renovação máxima por até cinco anos. Os profissionais selecionados ficaram sob a tutela de profissionais da Coordenação Geral de Articulação Acadêmica da Capes.

Os OA respondem, especialmente, à coordenação dos cursos aos quais se vinculam. É a coordenação de curso que deve definir diretrizes gerais e específicas do trabalho dos orientadores acadêmicos. Os profissionais prestam contas, também, à coordenação de polo, que tem a função de controlar a frequência dos profissionais.

São consideradas funções dos orientadores acadêmicos (AMBIENTE..., 2010):

- Apoiar e acompanhar os tutores e os docentes no polo e no Moodle;

- Colaborar com a avaliação dos estudantes;

- Coordenar pesquisa e/ou extensão com alunos;

- Organizar e incentivar atividades curriculares ou extracurriculares;

- Realizar diagnósticos do andamento do curso e do aproveitamento dos alunos;

- Relatar problemas ao coordenador do curso;

- Incentivar o aluno e buscar reduzir a evasão.

Além destas funções, os orientadores acadêmicos contribuíram, nos estados em que os cursos ainda não haviam se iniciado, com a estruturação destes cursos, realizando trabalhos junto à coordenação do curso, fora, portanto, do polo em que fora alocado.

O perfil dos orientadores acadêmicos alocados no estado do Tocantins, seis no total, sendo quatro de Química e dois de Física, é o seguinte: um é doutor, todos são mestres; 4 são licenciados; apenas um possuía experiência anterior com EaD.

A situação dos OA sempre foi precária. Apenas dois OA foram alocados em cidades que possuíam polos e, efetivamente, receberam os cursos posteriormente. Um terceiro, lotado no interior, também passou a atuar junto à sua coordenação de curso, em Palmas. Os demais sofreram com desvio de função nos seus polos, atuando como auxiliares do coordenador de polo e em atividades de outros cursos do polo. Mesmo nesta situação, nossos contratos, inicialmente válidos por 90 dias, foram renovados à época, retroativamente a janeiro ou fevereiro de 2010 .

A atuação dos OA começou a se definir nesta época. No caso dos cursos de Física e de Química da UFT, os coordenadores de curso atuavam e respondiam como chefes dos OA, enquanto à coordenação de polo coube apenas o controle da frequência. Como os cursos ainda não estavam implantados, os OA sempre atuaram abaixo da sua capacidade produtiva. Quando os cursos efetivamente começaram, os OA ligados às coordenações de curso 
passaram a atuar plenamente, visitando polos, estruturando cursos, adequando a estrutura do Moodle ou atuando com gestão de cursos junto à UFT, à Secretaria de Ciência e Tecnologia do Tocantins e à Capes.

O responsável por cuidar das atividades dos OA na Capes sempre deixou clara a precariedade da situação contratual, especialmente diante da baixa expectativa de que os cursos do Tocantins estivessem abertos até o fim daquele ano. Diante da ameaça de desemprego e dada a expressiva expansão dos quadros docentes das universidades e institutos federais em 2010, os OA buscaram incessantemente novas colocações, desta vez estáveis. Três dos OA assumiram funções docentes na UFT e outros três em institutos federais. Dos seis ex-OA, apenas dois seguiram atuando junto aos cursos na modalidade a distância da UFT.

Para o entrevistado Y, a experiência com os OA não foi adequada para uma avaliação correta sobre a sua importância. Uma vez que os OA atuaram em um período que não correspondeu ao do efetivo funcionamento dos cursos e, especialmente, em cidades que não abrigaram o curso quando este efetivamente se iniciou, o referido entrevistado declarou tal experiência insuficiente para julgar o trabalho desempenhado. A exceção teria sido a dos OA que atuaram junto à coordenação de curso, que teriam dado apoio fundamental: em um período em que os cursos não contavam com tutores, coordenadores de tutoria, professores ou estagiários, os OA teriam servido como auxiliares qualificados para desempenhar as tarefas que se colocavam naquele estágio de estruturação do curso. 


\section{CURSOS EM FOCO: CENÁRIOS, FIGURINOS E A AÇÃO}

Depois de tratar dos aspectos da constituição dos cursos nas duas universidades e de tratar dos papéis desempenhados pelos principais atores envolvidos, faço a análise que segue, versando sobre materiais didáticos, práticas de laboratório, ambiente virtual de ensino-aprendizagem, estágios obrigatórios e outros elementos importantes para se descrever e analisar as ações dos diversos personagens, as quais também são abordadas neste capítulo.

\subsection{Os primeiros atos na UFT}

Em outubro de 2010, com os alunos já matriculados, houve uma reunião no CTE (atual DTE), em Palmas, para que os coordenadores de curso planejassem em conjunto a aula inaugural $^{31}$, a capacitação de tutores e professores e, por fim, o curso de nivelamento dos novos alunos, a ser oferecido em novembro. Destes três pontos, o único que foi, de fato, comum aos dois cursos foi o nivelamento dos ingressantes e, ainda assim, parcialmente. A primeira capacitação coletiva de tutores só viria a ocorrer quase um ano depois, e as aulas inaugurais foram discutidas internamente nos grupos de apoio à coordenação de cada curso ${ }^{32}$.

O curso de nivelamento propriamente dito teve um módulo presencial de oito horas, versando sobre introdução à informática e introdução ao Moodle, em ambos os cursos, ministrados independentemente nos polos de Física e de Química. Tais cursos, integralmente ofertados pelo Moodle, com carga de trinta horas cada um, reuniram as turmas dos dois cursos no mesmo ambiente virtual e com os mesmos professores. Os cursos foram: introdução à EaD, ministrado por mim; tópicos de expressão escrita em língua portuguesa; e Matemática. Os cursos foram ministrados sem o apoio de tutores, que não puderam ser convocados naquele momento.

\footnotetext{
${ }^{31}$ A apresentação dos alunos no dia da inauguração do curso no polo de Gurupi, no mês de outubro de 2010, mostrou histórias interessantes, apesar de uma quantidade grande de alunos terem dito que fizeram o vestibular por acaso. Há de se destacar, em especial, a expectativa de parte dos alunos quanto à intensiva existência de aulas presenciais: dois alunos chegaram a se dirigir ao polo para assistir a aulas no dia em que se iniciariam as atividades no Moodle. Este foi o primeiro impacto da realidade dos alunos na coordenação de curso.

${ }^{32}$ Até aquele momento, não havia colegiados de curso. Embora existissem no papel, no PPC de cada curso, os colegiados ali descritos nunca se reuniram. Ambos os cursos tinham um grupo de colaboradores mais próximos, o que incluía outros professores da UFT e orientadores acadêmicos.
} 
O curso de Química ofereceu, adicionalmente, um momento presencial de encerramento do módulo de nivelamento. Além de entendermos que seria importante um apoio presencial nesta fase de recepção dos alunos, acredito que o módulo de Matemática, por não ter exigido dos alunos a realização de atividades e não ter sido acompanhado com regularidade no ambiente virtual pelo docente responsável, não tinha atingido os seus objetivos; entre eles, o de mostrar aos alunos que o curso $\mathrm{EaD}$ é tão rigoroso quanto o presencial. De fato, de acordo com o referencial freireano, educação deve ser diálogo, ação que não se observou neste caso. Eu precisei oferecer, nos polos do curso de Química, uma aula presencial destacando tópicos matemáticos, como operações com frações e regras de três e, para não distribuir certificados de participação indistintamente a todos os alunos, exigi a realização de um exame ao fim da aula, no mesmo dia do encerramento dos cursos.

Em relação à existência de momentos presenciais, nota-se que a Química os ofereceu em todas as disciplinas, enquanto a Física optou por não realizar encontros presenciais, mantendo o curso de nivelamento completamente a distância, com atendimento via comunicador instantâneo nos dias dos encontros presenciais obrigatórios. Tal conceito de EaD parece seguir a lógica de mercado vivida na Eadcon/Unitins, em que o número de "centros associados" (espécie de polo não registrado) e a falta de apoio de pessoal qualificado nesses centros leva o curso a ser $100 \%$ a distância, deixando o aluno sem assistência pedagógica. Preocupa, especialmente no caso de disciplinas de exatas, como Matemática, Estatística, Física e Química, imaginar que os alunos tenham de aprender obrigatoriamente sem apoio do professor ou mesmo de um tutor qualificado, ou seja, em uma educação como transferência de saber, sem espaço reflexivo e dialógico e, pior, sem garantias de que tal transferência consiga acontecer em condições tão adversas.

No entanto, uma interpretação mais livre da página de internet sobre a EaD na UFT possibilitaria depreender que a universidade não entende ser imprescindível haver um professor presente e atuante, já que "a aprendizagem nesta modalidade acontece de forma autônoma [...], onde o [estudante] se torna sujeito ativo e responsável pelo seu processo de ensino e aprendizagem" (UNIVERSIDADE FEDERAL DO TOCANTINS, 2011). Diante desta colocação, parece difícil convencer um coordenador de curso da universidade a fazer uso de encontros presenciais e tornar os professores de seu curso mais ativos e corresponsáveis pelo aprendizado dos alunos, apesar de a experiência do curso de Biologia $\mathrm{EaD}$ da UFT ser a de que os encontros presenciais, antes previstos para ocorrer mensalmente, tenham logo passado a ser quinzenais, atendendo a uma demanda dos alunos, segundo Flores (2010). Por outro lado, possivelmente, o excesso de aulas presenciais leve os alunos a 
abandonar o estudo solitário, associando o seu aprendizado ao contato presencial com o professor e responsabilizando-o por eventuais fracassos. Isto segue a linha da observação de Angotti (2006), ao atuar na formação inicial e continuada de professores de Ciências e Matemática, nas modalidades a distância e semipresenciais:

\begin{abstract}
"Um equívoco flagrante na condução do curso em geral, que se refletiu em muitas disciplinas foi a forte referência ao componente presencial, com expectativa exagerada tanto de nossa parte, como principalmente dos matriculados. Aos poucos, procuramos coletivamente uma melhor dosagem entre as atividades a distância e presencial, e obtivemos sensível melhora no final do primeiro curso e em todo o segundo." (p.145)
\end{abstract}

Outras experiências nesta área também nos permitem realizar uma análise mais ampla. Por exemplo, apesar de a UFSC ser um modelo inicial para a UFRN, esta última não conseguiu garantir o acompanhamento presencial por parte dos professores. É preciso destacar que o estado de Santa Catarina, o único atendido pela UFSC, tem área menor que o de Pernambuco, um dos quatro estados atendidos pela UFRN (os outros são Paraíba, Alagoas e o próprio Rio Grande do Norte). A grande área a ser coberta e a excessiva distância inviabilizou o atendimento presencial obrigatório ${ }^{33}$. A impressão obtida na visita à UFPI foi a de que é necessário haver momento presencial, seja com os professores ou com os tutores a distância, ou seja, com algum especialista de cada disciplina, para que os alunos se sintam assistidos e o diálogo seja pleno. O vínculo criado entre os alunos e os professores visitantes por lá não deixa dúvidas sobre a importância do contato presencial.

Para atender às exigências em futuras avaliações externas do curso, a coordenação da licenciatura em Química passou a exigir dos professores a elaboração de um plano de curso para cada disciplina ministrada. Dentro do referencial freireano, isto é positivo, já que estimula nos professores a consciência reflexiva sobre a estrutura da disciplina, do curso e das aulas. A coordenação do curso, que possui um ambiente coletivo de discussão no Moodle, que pode ser acessado por professores, tutores, coordenadores de polo e alunos, propôs a discussão de um modelo de plano de curso em um fórum. A partir da participação de diversos membros do colegiado naquele fórum, chegou-se a um consenso. $\mathrm{O}$ documento final, então, foi submetido diretamente a votação em colegiado e aprovado como modelo, da mesma forma que na UFRN, os professores possuem uma planilha padronizada para apresentar o plano de curso de suas disciplinas. Este é um exemplo não raro de trabalho cooperativo entre os

\footnotetext{
${ }^{33}$ De fato, as entrevistas na UFRN refletem que muitos professores gostariam de estar mais presentes, mas não podem devido à distância entre Natal e alguns polos. A redução da atividade nos polos fora do Rio Grande do Norte e o surgimento de novos polos potiguares levou a um recrudescimento da frequência espontânea dos professores aos polos, como relata o entrevistado $\mathrm{G}$.
} 
membros do colegiado de Química. Este caso ilustra uma preocupação crescente da coordenação do curso de Química em fazer coletivas as decisões e as produções dos seus membros. A abertura ao diálogo não poderia ser mais coerente com o discurso freireano, no qual, segundo Ramacciotti (2010), precisam estar o saber escutar, a tolerância, o respeito ao conhecimento do educando, a curiosidade epistemológica, a construção coletiva do conhecimento, a emancipação e a capacidade crítica.

\subsection{Os materiais didáticos e os conteúdos curriculares}

Para iniciar a abordagem dos materiais didáticos dos cursos, convém lembrar que a educação pela via da aprendizagem solitária difere da educação convencional especialmente no trabalho com os textos: presencialmente, o professor consegue sugerir oralmente um roteiro para o estudo, e o aluno pode sanar dúvidas imediatamente, enquanto na $\mathrm{EaD}$ as sugestões prévias raramente são dadas oralmente (o professor precisaria gravar som ou vídeo e disponibilizar a gravação no ambiente virtual) e o aluno poucas vezes consegue sanar as dúvidas no exato momento em que elas são geradas, uma vez que a comunicação síncrona é uma parte menor da $\mathrm{EaD}$, em relação à comunicação assíncrona, o que concorda com as colocações de Neder (2004). De fato, o entrevistado M chega a sugerir que, devido a esta limitação, a aprendizagem na $\mathrm{EaD}$ é menor - opinião não compartilhada com o entrevistado $\mathrm{D}$, por exemplo. Independentemente da razão de cada um destes entrevistados, é fato que não se pode desprezar esta diferença entre a educação presencial e a $\mathrm{EaD}$, ao menos nos moldes atuais, em que os ambientes virtuais são fortemente baseados na palavra escrita.

Para Neder (2004), o material didático da educação a distância tem melhores chances de êxito quando ancorado a documentos norteadores e organização coletiva dos envolvidos. Neste sentido, elaborar um projeto pedagógico baseado em temas geradores encaixa-se perfeitamente com a ideia da autora sobre $\mathrm{EaD}$ :

“A produção, a seleção e a organização de textos para a EaD devem estar atreladas ao projeto político pedagógico do curso que se quer desenvolver. Todo texto, concebido como material didático, deve ser pensado e concebido no interior de uma proposta curricular, que, por sua vez, deve ser construído na perspectiva de objetivos delineados em um projeto político de formação" (p.166).

Para Fernandes e Angotti (2006), o material impresso deve ser elaborado com o objetivo de servir de espaço de diálogo entre professor e aluno, utilizando linguagem dinâmica e motivadora. É o que permitiria ao aluno não se sentir isolado e desenvolver a sua 
autonomia. Além disso, este material deve enfatizar que os conhecimentos devem ser alcançados em regime de colaboração com colegas, tutores e professores. Para Fernandes (2007), é necessário ampliar as competências dos autores de materiais pedagógicos para EaD, pois o conteúdo mediado pela tecnologia exige uma atualização das práticas.

O material didático de cada disciplina ou componente curricular dos cursos examinados é dividido, em geral, em 15 fascículos, sendo distribuído, no caso da UFRN ${ }^{34}$, semana a semana ao longo das semanas que constituem o semestre letivo. Para o entrevistado $\mathrm{D}$, isto representa uma tentativa de vincular o aluno ao polo e, ao mesmo tempo, determinar o seu ritmo de estudos. As apostilas do material didático também são arquivadas nas bibliotecas dos polos, para consulta.

O modelo de elaboração de textos da UFRN exigia pelo menos dois professores conteudistas para cada disciplina, de forma que já houvesse, previamente, entre os professores, uma discussão sobre a clareza e a concisão do texto antes de submetê-lo à revisão por parte da equipe da Sedis. $\mathrm{O}$ entrevistado $\mathrm{M}$ entende que, apesar de ter havido este cuidado de exigir sempre ao menos dois professores elaboradores, o material foi produzido com características de um texto voltado à educação presencial. A ideia que se pretendeu usar como base para a confecção dos materiais teria sido a de ensinar o aluno a estudar sozinho e a aprender fazendo por meio do estudo da realidade. Neste aspecto, a UFRN buscou atender ao conceito de Neder (2004), citado pouco acima. No entanto, para o entrevistado D, em geral, o material produzido não conseguiu atender a este propósito ${ }^{35}$. O entrevistado $\mathrm{M}$ diz que o material produzido acabou não tendo características de material para $\mathrm{EaD}$, tampouco de material para um curso de licenciatura.

Segundo o entrevistado D, no início, a elaboração era feita coletivamente, o que foi difícil de manter. No primeiro semestre só foram oferecidas disciplinas interdisciplinares, iguais para os três cursos. Ou seja, o conceito de produção coletiva que está associado à aplicação do tema gerador como norte didático foi, de fato, observado, ainda que parcialmente. São cinco as disciplinas do primeiro semestre. Três delas foram elaboradas de forma mais integrada: "Educação e Realidade" (pensada, segundo o entrevistado D, para ser

\footnotetext{
${ }^{34}$ Os cursos da UFT preveem que as disciplinas devam ser ministradas em 9 semanas, o que leva a uma redistribuição das aulas da UFRN: acomodam-se 15 aulas em 9 semanas. Assim, o ritmo de estudos é definido pelo professor, e não pelo autor.

${ }^{35}$ Tais problemas não são incomuns em materiais didáticos de EaD. Fernandes e Angotti (2006) relatam que o material impresso do curso de licenciatura em Física da UFSC persistia com a ideia de um ensino tradicional e que, apesar de a linguagem utilizada no ambiente virtual ser mais coloquial, este ambiente era muito pouco utilizado.
} 
uma introdução às Ciências Sociais), "Ciências da Natureza e Realidade" (espécie de "carro-chefe" do primeiro semestre, segundo o entrevistado D) e "Matemática e Realidade" (cuja ideia era a de servir de ponte entre as outras duas). Também são disciplinas do primeiro semestre: "Informática e Educação"; "Geometria Plana e Espacial".

Neste tipo de produção, segundo o entrevistado $\mathrm{D}$, havia um problema: por mais que a equipe estivesse integrada na elaboração do material, este tinha um prazo para ficar pronto, o que limitava as possibilidades de reelaboração. A ideia era a de fazer um ajuste do material, mas não foi possível fazê-lo, disse o entrevistado D. Afinal, havia a necessidade de definir uma grande quantidade de fatores relacionados ao curso para além do material didático. Assim, a interação foi deixando de acontecer e cada vez mais ficando concentrada na mão dos coordenadores de curso. Com a interrupção das frequentes reuniões para definições de ordem pedagógica, o material produzido passou a ficar abstrato. Afirma o entrevistado D que o material assim produzido não abandonou a problematização, contemplou o aprofundamento, mas pecou pela falta de conteúdos e componentes curriculares de síntese do conhecimento aprendido, o que configura desvio em relação ao referencial freireano.

A estratégia inicial da UFRN foi a de priorizar o material escrito. Isto teve uma importância especial porque, segundo o entrevistado B, não havia uso significativo do ambiente virtual nos dois primeiros semestres do curso. $\mathrm{O}$ entrevistado $\mathrm{D}$ confirma que o acesso à internet pelos alunos era bastante limitado e a maioria dos alunos não sabia operar computadores. No entanto, a entrega do material didático aos alunos, sempre passou por percalços: a corrida para produção de material no prazo foi um desafio ao longo de todo o curso, de acordo com o entrevistado $\mathrm{D}$; muitos professores não haviam dimensionado adequadamente o tempo exigido para a confecção do material, tendo sido necessário o uso de materiais em "versão do professor", afirmou o entrevistado B; houve atraso e, em alguns casos, fracasso nos processos de licitação para contratação de gráficas para a impressão dos materiais ${ }^{36}$. O entrevistado B diz que parte das dificuldades foi contornada com: uso de cópias xerográficas custeadas pela Sedis em substituição ao material que não havia sido impresso a tempo; uso de CDs com o conteúdo; remarcação do calendário acadêmico pelos professores prejudicados. No caso do curso de Física, diz o entrevistado B, atrasos (não somente devidos aos materiais) fizeram com que os primeiros alunos só conseguissem colar grau depois de 4

\footnotetext{
${ }^{36}$ Obtive relatos de problemas em licitações para impressão de materiais didáticos no Piauí, no Rio Grande do Norte e no Tocantins. Trata-se de problema comum.
} 
anos e meio da data de ingresso, e ainda assim porque uma última disciplina pôde ser ofertada como um "curso de férias", ao fim dos 9 semestres.

Segundo o entrevistado M, desde o início havia o ideal de reescrever o material ao fim de 5 anos, acrescendo a ele as novas experiências adquiridas a partir da sua efetiva aplicação. No entanto, não houve menção de nenhum professor entrevistado sobre tal perspectiva para breve. $\mathrm{O}$ entrevistado $\mathrm{K}$ foi o único a tratar do tema, e disse que o projeto gráfico do material é o que está sendo revisto, especialmente com o objetivo de aumentar a legibilidade da impressão em cor única e, assim, facilitar a xerocópia. O entrevistado B aponta que o material didático foi, com grande esforço, sendo escrito à medida que o curso prosseguia, o que aponta talvez uma justificativa para o material não ter sido revisto. $\mathrm{O}$ entrevistado $\mathrm{M}$ afirma que o material didático, apesar dos esforços, ainda deixa a desejar em certos aspectos. Sua pequena integração com o ambiente virtual seria um destes problemas.

O material didático impresso utilizado nas licenciaturas em Física e em Química da UFT é exatamente igual àquele que é utilizado nos cursos congênere da UFRN. Entretanto, uma vez que o tema gerador da UFRN não é adequado à realidade do Tocantins ${ }^{37}$, ficaram os OA de Física e de Química responsáveis por discutir a alteração do tema gerador original e realizar a adaptação do material, o que ocorreu ao longo do primeiro semestre de 2010. Esta fase não foi simples, pois muitos dos envolvidos, especialmente os gestores, não são da área pedagógica e alguns deles nunca haviam sequer ouvido falar de Paulo Freire até o início das discussões.

Inicialmente, a discussão foi interna, sobre alguns dos processos que poderiam nos levar ao contato com a realidade do estado do Tocantins. No entanto, não foi preciso ir muito longe: apesar de a maioria dos professores e gestores envolvidos no projeto ser composta por imigrantes, muitos dos alunos e técnicos dos cursos da UFT são tocantinenses e puderam contribuir, em boa medida, com alguns temas geradores potenciais. Alguns professores também auxiliaram nesta busca, por possuírem projetos locais de pesquisa em andamento na universidade.

A partir destes temas iniciais, os orientadores acadêmicos avaliaram os diversos desdobramentos possíveis para cada tema, chegando à conclusão de que o primeiro tema gerador sugerido, "cerrado", seria o mais apropriado. Entre as razões apontadas estão: a

\footnotetext{
${ }^{37} \mathrm{O}$ clima do Tocantins se define por uma estação seca e uma chuvosa, enquanto a temperatura mantém-se alta, pouco variando ao longo do ano. A duração e a intensidade da estação seca aumentam do norte ao sul, sendo que a região de Gurupi e Paranã, a sul, por exemplo, fica em média quatro meses sem chuvas por ano. O Bico do Papagaio, no extremo norte, por outro lado, não possui mês sem chuva (NASCIMENTO, 2009).
} 
amplitude do tema em relação aos demais, já que seria mais fácil relacionar este aos demais temas surgidos; a similaridade com a proposta didática potiguar; o fato de que o cerrado ocupa quase $88 \%$ do território do estado (NASCIMENTO, 2009), ao mesmo tempo em que se diferencia em formas particulares nos ecótonos (áreas de transição ambiental), dependendo da região do estado: pântanos, florestas, caatinga. Este levantamento, portanto, acabou fazendo coincidir, em parte, o tema gerador proposto nos PPC de cada curso, que, como discutimos, foi determinado em discussões internas sem uma pesquisa junto ao público atendido. Esta, talvez, tenha sido a principal ocasião em que, clara e conscientemente, utilizamos um procedimento que fazia uso de algo que realmente havia sido pensado pelos elaboradores da UFRN.

Vale, também, destacar que, apesar de estas discussões terem ocorrido, os orientadores acadêmicos do curso de Física, responsáveis pela adaptação do material das disciplinas de "Geometria Plana e Espacial" e "Matemática e Realidade", pouco introduziram o tema "cerrado", preferindo buscar informações genéricas sobre o estado do Tocantins. Esta opção é, de certa forma, compreensível: o que fizemos foi um caderno de erratas, chamado “complementar", ou seja, não reescrevemos o material original, mas apenas indicamos aos alunos alterações específicas nas partes cujo tema merecia releitura no contexto tocantinense. O único material que foi extensivamente modificado e realmente passou a tratar o cerrado como tema gerador foi o de "Ciências da Natureza e Realidade", reelaborado integralmente pelos quatro OA de Química, com o apoio da coordenação do curso.

Isto, no entanto, só ocorreu no primeiro semestre do curso, já que o tema gerador não aparece nem nos materiais originais da UFRN nos semestres seguintes de forma significativa. O único material completamente inédito confeccionado na UFT, além do material de "Ciências da Natureza e Realidade", foi o manual do aluno, elaborado pelos orientadores acadêmicos de Física e de Química com a supervisão dos coordenadores dos cursos.

O sucesso na construção de um material autêntico da UFT sugere que a universidade nortista pode, sim, propor a reelaboração dos materiais didáticos, de forma a atender as particularidades do curso. Não se trata, aqui, de dispensar repositórios de materiais já existentes, como o Portal do Professor, por exemplo, mas de criar ou adaptar materiais existentes à realidade do Tocantins e às particularidades do projeto pedagógico. Entretanto, deve ser levado em consideração o fato de que, agora, os autores do caderno complementar, os OA, não atuam mais no sistema, o que demandaria a busca de profissionais para a revisão e o consequente financiamento, por meio de bolsas de professor conteudista, algo que não costuma ser fácil. 
O manual do aluno e o caderno complementar foram os únicos materiais impressos a tempo de serem entregues aos alunos no início do curso. Nenhum outro material impresso foi entregue aos alunos nos dois primeiros semestres. De forma paliativa, a DTE mandou gerar CDs com o conteúdo dos primeiros semestres, bem como imprimiu 10 cópias do material desses semestres para cada polo. Trata-se de quantidade insuficiente, já que, apesar de já ter havido alguma evasão, o número de alunos era certamente maior que 10 na maioria desses polos, especialmente no primeiro semestre. A falta de material didático impresso em quantidade suficiente para os alunos gerou dificuldades de gerenciamento de tempo para os mesmos. A principal restrição é a de que, como seus computadores são de mesa (e não portáteis), o único modo de estudarem em qualquer lugar e tempo onde tenham oportunidade é carregando o material impresso.

Não se trata, aqui, de defesa do material impresso em detrimento dos meios digitalizados. A questão é que as demais alternativas são, atualmente, inviáveis ${ }^{38}$. Outro exemplo de restrição a alternativas digitais de distribuição do material didático é a sofrível falta de banda de comunicação de dados em polos que ficam fora do eixo Capital e Rodovia Belém-Brasília. Em outras palavras, Palmas, Porto Nacional e Gurupi, por serem cidades maiores e mais bem localizadas em termos das estruturas de transporte e comunicação do Estado, têm conexão de internet em velocidade suficiente. Ananás e Cristalândia, por outro lado, têm conexões extremamente lentas nos polos. O caso de Cristalândia é bem ilustrativo: os mais de 30 computadores do polo, no fim de 2010, tinham de compartilhar uma conexão de somente 1 megabit por segundo (Mbps). Obviamente, torna-se impensável até mesmo o uso de comunicadores instantâneos baseados em voz (tecnologia VoIP), quanto mais o uso intensivo de vídeos síncronos ou assíncronos, nestes polos.

Na UFRN, os professores têm a opção, à qual muitos recorrem, de gravar videoaulas no estúdio da Sedis. Tais aulas podem ser disponibilizadas na internet, sendo acessíveis pelo Moodle, ou mesmo distribuídas em DVDs aos polos e arquivadas em suas bibliotecas. A UFT tem previsão de abrir o seu estúdio de gravação até o fim de 2012, sendo, portanto, ainda raro que professores gravem vídeos. Todas as produções de vídeo da UFT, até o momento, foram de baixa qualidade, amadoras, realizadas pelos próprios professores.

Os livros adquiridos para os alunos da EaD também foram um problema na UFT. A luta para que os livros da $\mathrm{EaD}$ não fossem destinados às bibliotecas dos campi, mas sim aos

\footnotetext{
${ }^{38}$ Deslandes e Mendes (2005) têm conclusão semelhante em curso de formação de professores a distância pela Universidade Federal de Ouro Preto.
} 
polos, foi longa e dura, mas, ao fim de quase um ano de discussões, os livros foram encaminhados aos polos. Em outras ocasiões, no entanto, venceu a burocracia. Em 2010, foi solicitado pela coordenação UAB que as coordenações de curso elaborassem listas de livros para aquisição. De acordo com a recomendação feita à época, cada título deveria ser solicitado à razão de um exemplar para cada cinco alunos, independentemente de o livro ser muito utilizado ou não. Assim ocorreu, embora, certamente, pudéssemos ter muito mais variedade de títulos nos polos e, especialmente, disponibilidade das obras mais importantes, se houvesse a flexibilidade e a coerência de pedir mais de um exemplar por cinco alunos no caso dos livros mais consultados, e menos do que isso nas obras de bibliografia complementar ou suplementar, que raramente são consultadas.

Com o crescente conhecimento dos envolvidos com o curso de Química, cresceu, também, a insatisfação com o currículo do curso. Embora o projeto pedagógico e seu viés freireano não tenham sido alvo de críticas, seja por desconhecimento ou porque ele tenha se mostrado adequado na aplicação com os alunos, a grade curricular em si vem sendo criticada desde o fim do segundo semestre do curso nas reuniões do colegiado do curso, como mostram as atas das reuniões. Houve um princípio de movimentação no sentido de constituir uma comissão de revisão curricular, havendo, inclusive, uma proposta, minha, de que três professores elaborassem uma nova grade, sendo um da área da ciência básica, um da área pedagógica e um terceiro da área de ensino de ciências. Esta ideia só não vingou por conta da extrema falta de tempo dos professores, mas a proposta de reformulação continua representando um objetivo que o colegiado de curso pretende alcançar.

De certa forma, a insatisfação também se deve ao fato de que o material da UFRN, em diversas disciplinas, mostra as características negativas de um texto escrito às pressas, sem a devida maturação das ideias, conhecimentos e competências que pretende desenvolver. Tal problema foi um dos mais claramente identificados nos diálogos da UFRN. Há uma crítica comum aos materiais utilizados feita por muitos dos professores do curso de Química da UFT neste sentido. A percepção sobre a necessidade de mudanças varia de professor a professor, mas a raiz da maior parte das críticas se deve ao fato de que as pessoas que elaboraram o currículo daquela forma não são as pessoas que o utilizam hoje. Pior: não é, sequer, possível chamar algum professor da UFRN para explicar a motivação da existência de cada disciplina no atual currículo, embora o nosso trabalho de entrevistas em Natal, reproduzido aqui, possa auxiliar enormemente para que se evite uma reconstrução a partir do zero. Não podemos chamar os elaboradores potiguares porque o currículo já sofreu mudanças significativas no âmbito da UFT, realizadas por pessoas que estão espalhadas pelo Brasil (muitas se 
transferiram para outras universidades), e cujo registro e justificativa do processo inexistem. Este é um aspecto para o qual devemos estar atentos em uma eventual reforma do currículo. O registro justificado sobre a necessidade ou importância de cada componente curricular pode guiar, no futuro, eventuais novas reformas.

Existe a consciência de que, não necessariamente, faremos melhor, mas de que podemos e devemos fazer um currículo "de baixo para cima", pensado pelos professores que o aplicarão, e não um currículo importado de uma universidade distante, sem sequer um estudo sobre se este seria a melhor referência curricular para a realidade do Tocantins, por mais que o projeto pedagógico original seja extremamente positivo, bem fundamentado e sedimentado. Afinal, não houve colaboração plena entre as IES envolvidas, como um suporte pedagógico da UFRN à UFT. Além disso, seguramente, tal processo de reforma seria mais rico se envolvesse professores, tutores e alunos.

Em relação aos conteúdos de cada disciplina, a preocupação também existe. Um exemplo que me espantou, em particular, e que representa uma razão para insatisfação, expressa em reuniões do colegiado da Química, foi o da disciplina "Matemática e Realidade". Apesar de termos detectado, nos cursos de nivelamento ministrados no último trimestre de 2010, que não eram raros os alunos que sequer sabiam operar uma regra de três, a referida disciplina se propunha a ensinar ferramentas de Estatística para além do básico, sem preocupação com a falta de conhecimento prévio dos alunos sobre diversos assuntos da Matemática da Educação Básica. O resultado, que deixou insatisfeito o colegiado, foi a altíssima taxa de reprovação na disciplina. No entanto, engessados pelo PPC, não havia como modificar a abordagem proposta para uma disciplina cujo nome engana: não tem tanto de Matemática quanto tem de Estatística, e pouco tem de Realidade, já que é a disciplina do primeiro semestre cujo material didático se encontra mais desconectado do tema gerador da UFRN, à exceção de "Informática e Educação".

Qualquer reforma nos cursos da UFT não pode deixar de levar em consideração a posição ainda atual de Pernambuco (1994):

\footnotetext{
"Ainda que não visando [a] uma mudança radical, uma ruptura com o presente, já estão colocadas as questões centrais, tanto para os pensadores quanto para os administradores educacionais:

- quais são os conteúdos escolares necessários para se dar conta de um momento de mudança tão rápida na produção do conhecimento e da informação?

- como enfrentar as contestações dos alunos, que vão da violência explícita à evasão, à não participação passiva, à utilização do espaço escolar unicamente como forma de buscar a "turma", a relação social, desconsiderando ou não dando importância às exigências acadêmicas?
} 
As reformas que estão sendo propostas, se não focalizarem as mudanças necessárias, no conteúdo, na metodologia, na organização escolar, não estarão enfrentando as raízes das questões que novamente irão reaparecer." (p.73)

É a partir de questionamentos como estes que os colegiados de curso da UFT devem basear a sua busca por um referencial pedagógico apropriado para a formação de professores para a escola tal como se apresenta hoje. Mas, se a opção for por manter o referencial freireano, vale considerar a fala do professor José André Peres Angotti, que, ao discutir comigo este trabalho durante simpósio na cidade de Araguaína, no Tocantins, em setembro de 2010, fez um paralelo com o seu projeto na Guiné-Bissau (ANGOTTI, 1982), entendendo que o povo local poderia participar dos cursos com seus próprios conhecimentos, tal como uma artesã da comunidade Mumbuca, em Mateiros, na região do Jalapão, por exemplo, poderia ensinar seus conhecimentos e, no curso, ele se "traduziria" em conhecimento à luz da ciência. Sem dúvida, seria o referencial de Paulo Freire usado em sua plenitude, em bases muito mais profundas do que as atualmente utilizadas no curso.

\subsection{O ambiente virtual de ensino-aprendizagem}

O ambiente virtual de ensino-aprendizagem utilizado na UFRN e na UFT é o mesmo: o Moodle. Apesar disso, a organização e a forma de uso diferem. As disciplinas no Moodle da UFRN e da UFT são organizadas por semanas, como o material didático. Trata-se de uma divisão diferente da que é utilizada, por exemplo, no Moodle da UFPI, em que a organização é utilitária (agrupamentos de fóruns, materiais didáticos regulares, materiais suplementares, salas de bate-papo etc.).

Em relação à interação no Moodle, ela era muito pequena no início dos cursos da UFRN, fato que se repete na UFT. Apenas a partir do segundo ano dos cursos da UFRN, a interação passou a ser mais expressiva. Infelizmente, isto não ocorreu na UFT. Além da falta de hábito ou conhecimento no uso dos computadores, para o entrevistado $\mathrm{M}$, para uma maior interação é preciso que o professor saiba dar abertura à pergunta no Moodle, como acontece na modalidade presencial.

Um incentivo à frequência dos envolvidos com $\mathrm{EaD}$ ao Moodle é a existência, em ambos os cursos da UFRN, de uma sala especial dentro do Moodle, como uma página do curso. É uma espécie de "sala virtual da coordenação", de acordo com o entrevistado J. Neste mesmo ambiente, há salas separadas, de uso exclusivo dos tutores, e de uso exclusivo dos 
professores, para discussões internas. Na UFRN, ainda que haja a interação virtual, há reuniões presenciais com os professores. O curso de Química da UFT criou a sua sala de coordenação no Moodle pouco depois de minha visita a Natal. Nela, são disponibilizados informes, notas provisórias, fóruns exclusivos de acesso para discussões entre tutores e professores, bem como uma sala reservada ao colegiado de curso. $\mathrm{O}$ ambiente tem sido bastante acessado pelos alunos, e servido para preparar as discussões entre os membros do colegiado de curso e do NDE. De acordo com o entrevistado W e com minhas buscas no ambiente virtual da UFT, não existe ambiente equivalente no curso de Física.

O entrevistado $\mathrm{G}$ observou, ao examinar as interações dos alunos no Moodle, que estes passam a incorporar e adotar a linguagem e o discurso do professor na interação. Assim, em sua opinião, esta seria uma medida indireta de verificação da aprendizagem. Segundo o entrevistado $\mathrm{M}$, que era uma das únicas duas pessoas autorizadas a ter acesso ao ambiente de todas as disciplinas de todos os cursos (ou seja, a ter acesso irrestrito às salas de aula virtuais), exatamente para poder avaliar e mediar eventuais atritos nas relações entre alunos, tutores e professores, em relação à forma de tratamento entre os atores, havia mais problemas com a rispidez dos professores do que com a dos alunos. Note, ainda, que, na UFRN, os próprios coordenadores de curso não possuem acesso às salas virtuais dos professores que selecionam, diferentemente da UFT, em que o acesso dos coordenadores aos ambientes de seus cursos é irrestrito. O entendimento na UFRN é o de que o ambiente de uma disciplina é como uma sala de aula, e não cabe ao coordenador de curso ter acesso a esse ambiente, da mesma forma que ele não assiste às aulas presenciais dos professores do seu curso.

O entrevistado G, na UFRN, entende que havia falhas de comunicação, especialmente no início dos cursos e das turmas, especialmente com alunos alegando não acessarem o Moodle com regularidade pelo desconhecimento de sua existência. Talvez a inexistência de um guia didático impresso para os cursos tenha influenciado. Tal guia, segundo o entrevistado $\mathrm{J}$, existe, mas está no próprio Moodle. Um problema persistente relacionado, segundo o entrevistado $\mathrm{B}$, é a dificuldade de acesso à rede nos polos, por baixa velocidade ou quedas frequentes do sinal de internet.

$\mathrm{O}$ entrevistado $\mathrm{M}$ ainda fala sobre o Moodle: considera-o lento, pouco alterado ao longo do tempo, ou seja, com ferramentas obsoletas que poderiam ter evoluído mais, e lamenta que haja apenas interação por texto. Similarmente, o entrevistado D entende que a $\mathrm{EaD}$ e, em particular, a Sedis está em um momento importante, no qual deve fazer a opção de investir no audiovisual, incorporando-o à dinâmica das disciplinas; também deve passar a usar outras mídias no processo de ensino e aprendizagem. 
Um dos problemas do Moodle da UFT é que o mesmo continuava, até agosto de 2012, sem ser capaz de reproduzir equações matemáticas. Trata-se de uma questão levantada pelos OA desde o início de 2010. Outro grande problema é a lentidão com que os problemas de acesso ao Moodle da UFT são resolvidos. Uma aluna do curso de Química, por exemplo, só conseguiu acesso ao Moodle quase 45 dias após o início do curso. Mais um problema ocorrido na plataforma Moodle mostrou pouca segurança e estabilidade na operação do sistema: uma falha computacional gerou problemas parciais no Moodle que levaram à necessidade da restauração do sistema a um ponto anterior. A questão é que o ponto anterior, ou seja, a última cópia de segurança disponível, havia sido feita cinco dias antes da falha. Assim, todos os professores, tutores e alunos, de todos os cursos EaD da UFT, perderam todos os trabalhos, avaliações e outras interações realizadas nesse período, assim como perderam o trabalho eventualmente executado na construção ou atualização do Moodle.

$\mathrm{O}$ treinamento para que professores, tutores e alunos consigam usar adequadamente o Moodle e tenham, também, uma introdução à linguagem e às características da $\mathrm{EaD}$ vem desagradando a alguns dos envolvidos com o curso. Embora o entrevistado $\mathrm{C}$ não tenha conseguido precisar a origem do problema, é fato que, no primeiro treinamento proposto aos tutores e professores do curso de Química, a prioridade foi absoluta para o funcionamento técnico do Moodle, não como ambiente de aprendizagem. Não se perguntou aos cursistas, tutores e professores em treinamento, se sabiam trabalhar com internet, nem se os instruiu para o trato com os alunos.

Uma das reclamações mais comuns dos professores que buscaram utilizar mais intensamente o ambiente virtual, fazendo dele algo maior do que um simples repositório de materiais didáticos tradicionais (apostilas em formato digital, textos complementares e atalho para envio de atividades) foi a de que os alunos não estavam participando. Dos poucos alunos que entraram no Moodle, a maioria, em lugar de participar, reclama pela apostila impressa, o que levaria, talvez, a um maior esvaziamento do Moodle. Desta forma, a utilização do Moodle como ferramenta plena de educação ainda parece distante de ocorrer. Há outro problema grave, relacionado, o qual trecho de Pernambuco (1994) ajuda a introduzir:

A relação entre conhecimento e linguagem é explorada por vertentes que vão da filosofia às teorias de comunicação. Sem querer escamotear as dificuldades de enfrentar uma questão tão ampla como fundamental, pode-se refletir sobre os seus aspectos operacionais $[\ldots]$.

No ensino fundamental, os alunos ainda têm dificuldade em lidar com a linguagem escrita. A oralidade, presente no cotidiano, admite supressões que não se encontram no texto e é complementada por gestos e expressões, que preenchem lacunas, reforçam ideias. A introdução dos alunos ao universo letrado é um dos objetivos básicos dessa etapa de ensino. Ao mesmo tempo, o seu domínio precário pelos 
alunos cria dificuldades na sua utilização para introduzir [...] novos conhecimentos." (p.93-94)

Como aponta a autora, é no ensino Fundamental que os alunos deveriam se habituar à expressão escrita. Quando a exigência de produção textual é reduzida na educação básica, o desenvolvimento do domínio da expressão escrita é extremamente prejudicado. É o que ocorre com muitos dos alunos dos cursos examinados, talvez a maioria. A produção de textos impenetráveis, não pela prolixidade, mas pela ausência de frases gramaticalmente ordenadas, ou de sequência lógica de raciocínio, ou pela falta de palavras, ou pelos múltiplos erros ortográficos elementares, é muito mais frequente do que o contrário. Outras vezes, não é preciso utilizar buscadores de internet para perceber que o texto entregue é plagiado: o professor já sabe que um texto limpo e lógico não pode ter sido produção daquele aluno. É possível que a ausência dos alunos no Moodle e a alta taxa de reprovação se devam à dificuldade de expressão escrita, a qual os alunos conhecem, mas não desejam expor aos colegas.

Os cursos da UFT também sofreram com problemas relacionados à baixa frequência de acesso dos professores ao ambiente virtual, como o caso do professor que não havia acessado o Moodle, mesmo após mais de um mês do início das aulas da sua disciplina. No curso de Química, o problema ocorreu com frequência com os primeiros professores. No curso de Física, os registros de acesso aos ambientes das disciplinas dos cursos de nivelamento mostram que, ali, o problema é ainda mais frequente.

Embora, no curso de Química, tenha ficado definida uma espécie de regra de separação de atribuições para tutores a distância e professores no Moodle, a qual previa que se a resposta a ser dada só exigisse copiar e colar um trecho da apostila, dar a resposta caberia ao tutor, enquanto se fosse necessário explicar, a tarefa caberia ao professor, tal regra possivelmente nunca tenha sido usada, já que os alunos raríssimas vezes usam o Moodle para eliminar dúvidas referentes ao conteúdo. Os fóruns de dúvidas de cada disciplina, em geral, só são usados para eliminar dúvidas sobre prazos e critérios de aprovação.

O uso dos registros de acesso ao Moodle ainda é muito superficial nos cursos da UFT. Existem casos de alunos que não acessam o ambiente de determinada disciplina por várias semanas e não é contatado pelo tutor presencial nem pelo tutor a distância (quando há). É possível que, se isto passasse a ser feito, os alunos e os professores conseguissem maior sintonia do que a atualmente observada. Talvez esteja aí a chave para que o Moodle da UFT deixe de representar apenas uma coleção de pontos negativos e passe a servir, de fato, como ferramenta essencial do estudo solitário interativo. 


\subsection{Aulas práticas: os laboratórios}

Os laboratórios dos polos da UFRN têm sido equipados aos poucos, embora não estejam completos de acordo com o desejado pelas coordenações de curso. Como os polos da UFRN ficam em quatro estados diferentes, sob as mais diversas administrações, as compras foram realizadas em processos diferentes, por instâncias governamentais diferentes, o que fez com que os equipamentos adquiridos fossem distintos. Assim, uma das tarefas dos tutores de laboratório, de acordo com o entrevistado B, é a descrição dos equipamentos que cada polo possui, para que o professor possa planejar os experimentos. Em relação à estrutura dos cursos e dos polos, o entrevistado B entende que, depois da criação do sistema UAB, os cursos criados no edital Pró-Licenciatura, como é o caso das primeiras turmas dos cursos da UFRN, receberam pouca atenção por parte da administração federal. O programa Pró-Licenciatura foi elaborado diretamente pelo MEC, enquanto a UAB é comandada pela Capes.

A Química pretendia, inicialmente, implantar laboratórios simples nos polos, para as práticas mais gerais, e mais um laboratório itinerante, sofisticado, usado nas práticas específicas. Tal ideia, cuja intenção era a de facilitar o acesso dos alunos a bons equipamentos e práticas mais elaboradas, foi descartada devido ao alto custo. No caso do curso de Física, os tutores a distância, quando vinculados a disciplinas de laboratório e para polos que não possuem laboratório próprio, levam equipamento para a realização do experimento. Há de se notar que, em especial para o caso da disciplina "Física Moderna Experimental", nem todos os experimentos planejados no material didático conseguem ser efetivamente realizados, por falta de equipamento. Isto, infelizmente, ocorreu mesmo depois de a Física adiar as disciplinas experimentais para o $4^{\circ}$ ano de curso, na expectativa de que chegassem os laboratórios a todos os polos. $\mathrm{O}$ entrevistado $\mathrm{G}$ relata a necessidade de os municípios possuírem os seus próprios laboratórios de Física. Um conjunto reduzido, mas suficiente de equipamentos foi selecionado pela coordenação de curso, limitado ao valor total de 5 mil reais. Tal conjunto foi adquirido pela prefeitura de uma única cidade, mas não pelas demais, o que, certamente, prejudica o planejamento docente.

$\mathrm{O}$ artigo $1^{\circ}$, parágrafo $1^{\circ}$ do decreto federal 5622/2005 garante que as aulas de laboratório devam ser presenciais. Não é diferente na UFRN. Nas disciplinas de laboratório de ambos os cursos, a presencialidade se faz obrigatória de forma indireta: a avaliação se torna difícil para os alunos que não participaram das práticas realizadas. Entende o entrevistado G que, na Física, há, ainda, espaço para aumentar a prova como forma de avaliar a parte 
experimental e que é necessária uma carga horária maior de aulas de laboratório, mas que isto ainda não pôde ser implantado. O entrevistado B diz ter estimulado professores, tutores e alunos da Física a realizar experimentos em todas as disciplinas, e não somente naquelas que previam carga horária prática.

O entrevistado $\mathbf{J}$ explica algumas das alterações projetadas para a nova grade da Química: reestruturação das práticas de laboratório de Química Analítica e Química Orgânica, focando nos equipamentos disponíveis e na necessidade de um licenciado em Química. O entrevistado $\mathrm{J}$ afirma que as práticas previstas atualmente nos materiais didáticos vinculam-se a um paradigma superado, muitas vezes com reagentes perigosos e/ou difíceis de encontrar. Não é o caso da UFPI, por exemplo, que relata não trabalhar com experimentos que geram resíduos não descartáveis em rede de esgoto doméstico.

Em relação à UFT, foram visitados alguns potenciais polos do curso de Química no fim de 2009 e no início de 2010: Araguacema, Mateiros e Araguatins. As duas primeiras cidades não tinham condição de abrigar um curso de licenciatura em Química: não havia laboratório didático e ambas as cidades se situam em regiões de preservação ambiental (rio Araguaia e Jalapão, respectivamente), dificultando, também, o transporte e o descarte de rejeitos químicos. O caso de Araguatins era um pouco diferente: ali há um campus do Instituto Federal de Educação, Ciência e Tecnologia do Tocantins (IFTO), e a abertura do curso poderia, eventualmente, ser viabilizada com o uso do laboratório daquela instituição, desde que houvesse acordo entre prefeitura, IFTO e UFT, o que não ocorreu. Cristalândia, município que não foi visitado, recebeu ambos os cursos, embora não tivesse sequer espaço para a construção dos laboratórios, estando, portanto, em situação pior que a de Mateiros. O polo de Cristalândia não foi reprovado ${ }^{39}$ na visita da Seed em 2010: não recebeu conceito R; por não ter, àquela época, cursos que exigissem laboratórios, também não recebeu conceito L; tal situação permitiu a instalação de ambos os cursos, Física e Química, naquela cidade. Quanto à situação dos polos reprovados, esta praticamente não mudou, passados quase dois anos desde a fiscalização da Seed.

\footnotetext{
39 Afirmam Costa e Duran (2012) que a Seed-MEC reprovava polos com conceitos R (polo que apresentava problemas críticos em sua infraestrutura) e L (polo com deficiência de laboratórios pedagógicos para os cursos ofertados na área experimental). Os polos qualificados com o conceito $\mathrm{R}$ teriam a entrada de novos alunos interditada pela Seed em todos os cursos; nos polos qualificados com o conceito L, a Seed interditou a entrada de novos alunos apenas nos cursos específicos em que se detectou precariedade ou inexistência de laboratórios experimentais. Em ambos os casos, a Seed determinou um prazo de seis meses para a correção dos problemas e convocou os mantenedores para a assinatura de um termo de ajuste que garantiria o comprometimento com a solução dos problemas no prazo, sob a condição de descredenciamento do polo.
} 
No caso da Química, as aulas práticas que exigem o uso de laboratório são realizadas nos campi da UFT que contam com tais instalações. Assim, os alunos do polo de Porto Nacional assistem às aulas de laboratório no campus UFT daquela cidade, bem como os alunos do polo de Gurupi têm à disposição um laboratório no campus local da UFT. Já os alunos do polo de Cristalândia eram obrigados, por sua própria conta e sem qualquer tipo de apoio financeiro, a se deslocar daquela cidade à cidade de Porto Nacional, distante $122 \mathrm{~km}$, para assistir às aulas de laboratório juntamente com os alunos do polo local.

A Prefeitura Municipal de Cristalândia não fornece transporte aos alunos. A Secretaria Estadual de Ciência e Tecnologia, corresponsável pela infraestrutura de polos, bem como a UFT, alegavam não ser sua obrigação o atendimento de tal demanda. Uma tentativa de contornar a situação, que a coordenação do curso de Química tentou colocar em prática por sugestão de uma tutora presencial, e que havia sido respaldada pelo colegiado de curso, foi a de utilizar o laboratório de uma escola estadual local. No entanto, a tentativa foi vetada pela DTE, que entendeu que a UFT não poderia ficar dependente de outra instituição sem o convênio adequado, além de não poder responder por eventos (como acidentes ou danos ao patrimônio) ocorridos fora de suas instalações. Após diversas tentativas de gestão do problema junto aos três órgãos supracitados, segundo o entrevistado Z, a coordenação do curso de Química conseguiu verba e veículo da universidade para o transporte dos alunos.

Por outro lado, o MEC, por meio da Capes, que gerencia o sistema UAB, forneceu à UFT um único laboratório de Física completo e, igualmente, um laboratório de Química. Trata-se de quantidade insuficiente de aparelhos para atendimento a três polos, portanto. No caso da Química, seria natural que tais equipamentos fossem destinados à cidade de Cristalândia. No entanto, tais equipamentos se encontram em suas embalagens originais desde que chegaram ao Tocantins, em meados de 2011, e não há previsão de que venham a ser instalados em Cristalândia pela inexistência de um laboratório ou outro espaço pronto para recebê-los até junho de 2012. Encaixotados na sede da DTE também se encontravam os equipamentos do laboratório de Física em março de 2012, quase um ano depois de chegarem à universidade. $\mathrm{O}$ polo de Cristalândia, segundo o entrevistado $\mathrm{Z}$, cadastrou, junto ao MEC, o laboratório da UFT de Porto Nacional como o laboratório de uso dos alunos do polo, reforçando a inexistência de perspectiva de alteração deste quadro em curto ou médio prazo.

Esta questão dos laboratórios foi determinante para a construção de novas diretrizes de reoferta e expansão dos cursos EaD da UFT. Os problemas que vêm se estabelecendo entre algumas prefeituras e a UFT, especialmente no que diz respeito às aulas práticas e à instalação dos laboratórios, fez com que a coordenação UAB da UFT tomasse uma decisão 
absolutamente contrária a um dos objetivos fundamentais do sistema UAB, que é a interiorização do ensino superior: foi decidido que, uma vez que o MEC tem sido rigoroso e reprovado polos que oferecem cursos que exigem laboratório e não os possuem, que os cursos de licenciatura em Ciências da UFT, para não serem descontinuados - isto chegou a ser pensado -, só serão ofertados em polos que contam com um campus da UFT que tenha laboratório. Isto restringiu a reoferta dos cursos, realizada pelo edital de concurso vestibular 72, de 3 de agosto de 2012, aos municípios de Palmas e Gurupi, no caso da Física, e a Palmas, Gurupi e Porto Nacional (a apenas $60 \mathrm{~km}$ de Palmas e cuja maioria dos atuais alunos reside na capital), para a Química.

É importante destacar outros aspectos que envolvem a questão. Um deles é a previsão, dada pelos PPC dos dois cursos, de existência das chamadas "Unidades Operativas", que reconheciam os campi da UFT como os únicos locais aptos a receber aulas de laboratório e livros. Assim, um aluno do polo de Araguatins (previsto pelo PPC de Química, mas nunca implantado) deveria buscar seus livros na biblioteca do campus de Araguaína, a $240 \mathrm{~km}$ de distância. Obviamente, esta solução surreal não foi colocada em prática. Outro aspecto é a percepção, compartilhada por alguns professores e coordenadores, de que cabe aos alunos custear viagens para as cidades que tenham campi da UFT, caso sejam alunos de um polo sem laboratório. Independentemente da postura de não inclusão de alunos carentes, a falta de respaldo do MEC para que um curso seja aberto em uma cidade cujo polo não tem previsão de receber laboratório didático, bem como a falta de apoio dos mantenedores de polo para viabilizar soluções provisórias (transporte) ou permanentes (laboratórios locais ou itinerantes) impediu a DTE de planejar a reoferta dos cursos em cidades sem laboratórios da UFT.

Por outro lado, a necessidade de um laboratório para todas as aulas práticas típicas de um curso presencial tradicional é questionável. Angotti (2006), nesta linha, aborda a falta de flexibilidade nas práticas de laboratório em cursos de formação inicial e continuada de professores de Física e áreas afins, nas modalidades a distância e semipresenciais, das quais participou:

\footnotetext{
"Outro aspecto limitante das três áreas científicas consistiu na parte experimental, com a obrigatoriedade dos laboratórios muito presos aos cursos presenciais, determinando experiências "reais" em regime $100 \%$ presencial. Em consequência, alcançamos menor êxito no aproveitamento das simulações e da virtualidade, tanto para complementação das atividades práticas, como para substituição de experiências ainda não desenvolvidas nas licenciaturas presenciais, por exemplo, de física moderna e contemporânea.

[...] Rodízios de experiências montadas em polos e itinerância de kits experimentais para cumprir as disciplinas de laboratório, associadas às potencialidades das redes eletrônicas e simulações já disponíveis, também são desejáveis.” (p.145)
} 
O entrevistado C concorda com a posição de Angotti (2006), lembrando que um curso $\mathrm{EaD}$ precisa de mobilidade. Uma vez que uma determinada região forma quantidade suficiente de professores de certa disciplina, o curso deve deixar de ser ofertado naquele local para ser oferecido em outro, mais carente e com mais demanda. A ideal mobilidade dos cursos na modalidade $\mathrm{EaD}$ se opõe à construção de dispendiosas estruturas permanentes que se tornarão ociosas em médio e longo prazo em cidades menores.

Pernambuco (1994) diz que "na maioria das vezes, a atividade experimental, quando existe, tem a função de ilustrar a teoria ou de introduzir o aluno ao 'método experimental', e é apresentada como uma receita a ser seguida" (p.88). Isto, na visão de Del Carlo (1997), é um equívoco, pois, para esta autora, o ensino de Ciências experimentais deve permitir o desenvolvimento da capacidade de observação e de percepção da natureza. Neste sentido, a atividade experimental não pode ser mera observação, devendo envolver intenções norteadas por aquilo que se pretende observar. Além disso, prossegue a autora, deve servir para auxiliar na compreensão dos conceitos científicos e suas relações, além de contribuir para o domínio da linguagem científica. Simulações computacionais adequadamente elaboradas podem ser capazes de atender a estes requisitos em muitos casos. É algo em que também acredita Giordan (1999): “...as simulações computacionais podem ser orquestradamente articuladas com atividades de ensino, sendo portanto mais um instrumento de mediação entre o sujeito, seu mundo e o conhecimento científico." (p.49).

Assim sendo, considero que se deva por em dúvida a necessidade de um laboratório dispendioso, que só ilustra fenômenos, em polos e cidades pequenas, que não podem arcar com tais custos, mas que precisam de professores de ciências. As alternativas, como itinerância de kits e simulações em ambiente eletrônico, merecem ser utilizadas plenamente. Devem-se manter práticas reais apenas naquilo que precisa ser real, transformando o “virtuável” em virtual. Note-se que não se sugere a redução do nível de qualidade da formação dos professores, mas sim que se atenda ao objetivo traçado pelo governo para o sistema UAB: solucionar a questão da baixa penetração do ensino superior nas cidades menores e da falta de professores da educação básica com a necessária qualificação e o imprescindível conhecimento nas mesmas cidades. 


\subsection{Aulas práticas: os estágios}

Os estágios curriculares também recebem atenção especial na UFRN. Para o entrevistado B, a existência de um tutor de estágio em cada polo representa uma superação no âmbito do sistema UAB, pois este bolsista, cuja necessidade é discutida nas reuniões dos coordenadores de curso promovidas pela Capes em Brasília, sempre existiu na UFRN. A implantação dos estágios obrigatórios dos cursos de licenciatura da UFRN foi centralizada, e só posteriormente os cursos passaram a ter, cada um, o seu coordenador de tutoria, o que possibilitou o controle do estágio separadamente, a partir do momento em que o coordenador de tutoria passou a acumular o gerenciamento e o controle dos estágios.

O projeto executado fez com que os estágios fossem cumpridos em três semestres, e não em quatro, como previsto inicialmente. São 100 horas de observação e 300 horas de regência, de acordo com o projeto do curso. A frequência do aluno ao polo nesse período é obrigatoriamente quinzenal, de forma que o tutor de estágio acompanhe a confecção dos diários reflexivos elaborados pelos alunos. Por sua vez, os tutores de estágio vão ao menos duas vezes em cada escola escolhida pelos alunos para estagiar (vale lembrar que muitos alunos não residem e, portanto, não estagiam na cidade em que o polo está instalado). De qualquer forma, os tutores de estágio seguem acompanhando o andamento do estágio a cada 15 dias, ligando para as escolas se não for possível o deslocamento até as instituições distantes. Cada grupo de 50 alunos tem três pessoas, entre professores e tutores de estágio, no acompanhamento deste estágio. Há, ainda, reuniões de capacitação de tutores de estágio a cada bimestre com os professores das disciplinas de estágio, além da interação virtual constante. Toda intervenção do aluno estagiário na escola é pensada em conjunto com o professor responsável pela disciplina de estágio. Os coordenadores de polo também têm sido bastante exigidos em relação ao controle dos estágios.

Germano (2009) afirma que o foco dos estágios é na realidade, na vivência de experiências, corroborando o viés freireano dos projetos dos cursos. O objetivo é seguir o ciclo "análise da realidade (...) > planejamento > desenvolvimento dialógico do plano > avaliação contínua/análise da realidade" (p.4). Segundo a mesma autora, outro fator freireano no formato atual do estágio da EaD na UFRN é a busca da contextualização dos conteúdos de ensino, estimulada em planejamentos na elaboração de projetos junto à escola.

O entrevistado G considera o modelo de estágio da UFRN bastante eficiente e vê cada disciplina de estágio como equivalente a duas disciplinas teóricas em termos do aprendizado 
que ela traz, especialmente se for pensado no contexto da valorização da atividade docente. Os entrevistados G e J concordam ao afirmar que o estágio na UFRN é bastante rigoroso, e se observa uma alta taxa de reprovação nas disciplinas de estágio. As razões para isto são: rejeição à confecção de diários extremamente genéricos (descrições muito sintéticas sobre o conteúdo de cada aula); detecção de plágios em planos de aula; falta de documentação comprobatória de estágio; entre outras. O entrevistado J descreve os estágios obrigatório nos cursos de licenciatura da UFRN como trançados, pois se apoiam em três vertentes interligadas: polo e seu tutor de estágio, escola e seu professor orientador, Moodle e o seu professor da disciplina. Germano (2009) aponta, ainda, um problema expressivo nos estágios dos alunos EaD da UFRN, já que nem sempre há profissional, na escola, com formação ou experiência na área do licenciando (Física e Química), o que, em última instância, é exatamente a justificativa para o incentivo ao uso da EaD na formação de professores, particularmente na área de Ciências da Natureza e Matemática.

A UFT ainda precisa discutir o seu modelo de estágio curricular, já que nenhuma das duas coordenações tomou qualquer atitude em relação ao tema até junho de 2012. Nem mesmo ficou definido se a coordenação de tutoria acumulará a coordenação de estágio, o que parece ser o primeiro passo para estruturar o estágio em si. A expectativa da criação da figura do coordenador de estágio bolsista no âmbito do sistema UAB, ainda não ocorrida, também pode atrasar o processo de elaboração das diretrizes do estágio na UFT. Uma das restrições que se observará, de qualquer forma, é a ausência da figura do tutor de estágio, caso se decida não utilizar o modelo da UFRN, que é promissor e se encaixa perfeitamente com a proposta dos PPC tocantinenses. Outra restrição é a dificuldade de acompanhamento do estágio na escola que o aluno escolheu, visto que há severas restrições de pessoal e de verbas para o deslocamento a cada escola.

Além do estágio, outro controle necessário ao fim dos cursos de licenciatura se refere ao cumprimento da carga horária de 200 horas referente às atividades acadêmico-científico-culturais (AACC). No curso de Física, o entrevistado G vem promovendo eventos nos polos, para contarem como carga horária de AACC. Tais eventos podem ser, de certa forma, entendidos como caravanas de professores, tutores a distância e pós-graduandos da UFRN a um certo polo do interior, onde são promovidas palestras, oficinas e grupos de estudos com o objetivo de integrar o curso com a realidade local, ou seja, realizar a contextualização dos conteúdos aprendidos nas disciplinas regulares. A Química não promovia nenhuma atividade especial até a época das entrevistas, embora o entrevistado $\mathrm{J}$ afirme que projetos de extensão em fase de planejamento poderão atribuir horas de AACC aos alunos. Apesar de tudo isso, os 
alunos não são dependentes da realização das AACC apenas nos eventos programados: há uma portaria que regulamenta as AACC no âmbito da Sedis. O entrevistado B diz que as AACC como eventos no curso de Física foram positivas porque serviram de porta de entrada de alguns professores ao projeto da $\mathrm{EaD}$.

Na UFT, apesar de o curso de nivelamento aplicado antes do início das aulas ter previsão para ser considerado na contagem das 200 horas obrigatórias de AACC, nenhuma outra atividade foi planejada pelos cursos para tal contagem. Apenas um curso promoveu viagem didática: o curso de Química levou os alunos em dezembro de 2011 a um simpósio da licenciatura em Química presencial da UFT na cidade de Araguaína. A experiência foi considerada positiva pelos alunos e pelo colegiado do curso, de acordo com a ata de reunião deste colegiado: os alunos assistiram a palestras de professores conhecidos da área do Ensino de Química, como Gerson Mol e Attico Chassot, além de ter contato com outros estudantes e profissionais, situações raras em um curso na modalidade EaD.

Por fim, a UFRN pretende levar o Programa Especial de Tutoria (PET), aos polos, ou seja, possibilitar que os alunos da $\mathrm{EaD}$ também possam participar deste tipo de projeto, reduzindo a distância daquilo que é oferecido aos alunos presenciais em relação aos alunos EaD. Na UFT, no entanto, até mesmo os cursos presenciais utilizam pouco as verbas destinadas ao programa, parecendo, portanto, muito distante a ideia de que o PET venha a constituir parte dos cursos da EaD na universidade, mesmo em longo prazo. Quanto ao Pibid, lamentavelmente, nenhuma das duas universidades dispõe: trata-se de um programa, na origem, vedado a licenciaturas a distância. A mudança de postura do MEC em relação a esta proibição, no entanto, não gerou, até junho de 2012, efeitos nos cursos estudados.

\subsection{Avaliação e frequência}

A avaliação é, também, um ponto nevrálgico do sistema de educação a distância. A questão é: como avaliar com confiabilidade? O entrevistado D, ao mesmo tempo em que reconhece serem relativamente frequentes os casos de fraude na avaliação, aponta que quanto mais tradicional é a avaliação, maior é a chance de que haja tal fraude. Algumas sugestões do entrevistado D incluem a possibilidade de se executar com segurança uma avaliação eletrônica, com perguntas aleatoriamente selecionadas a partir de um banco de dados, preferencialmente baseada na Teoria da Resposta ao Item, ou investir em formas contínuas de avaliação. 
Atualmente, na UFRN, a avaliação presencial é aplicada por tutores de forma alternada. Por exemplo, as avaliações do curso de Física são aplicadas por tutores de qualquer um dos demais cursos da UFRN no polo. Isto se faz na tentativa de buscar evitar fraudes. O entrevistado $\mathrm{G}$ relata problemas com fraude na aplicação de provas presenciais, com tutores sendo excessivamente permissivos com a postura dos alunos. De acordo com o entrevistado B, os coordenadores de polo, em alguns casos, foram chamados para combater tais práticas deletérias. Em outros, professores apareciam no dia da prova no polo, de surpresa, para aplicá-la no lugar dos tutores. Situações parecidas envolvendo fraudes nos exames começam a ser verificadas nos cursos da UFT, sem que se tenha pensado em uma solução mais generalizada.

Quanto ao plágio na UFRN, para o entrevistado M, o controle e a repressão são de responsabilidade do professor de cada disciplina. No caso do entrevistado J, a orientação dada é a de devolver o trabalho plagiado ao aluno para que refaça. Os cursos da UFT ainda não têm uma orientação geral para lidar com os casos, além de muitos professores não estarem atentos a isto, o que tem levado a uma nefasta proliferação deste tipo de fraude entre os alunos.

Mais recentemente, o controle das notas da UFRN passou a ser feito por meio de seu Sistema Integrado de Gestão das Atividades Acadêmicas (Sigaa), antes restrito aos cursos presenciais. Isto permitiu fazer com que o professor também fosse avaliado pelo aluno, algo que é especialmente importante na $\mathrm{EaD}$, segundo o entrevistado $\mathrm{K}$. A dificuldade na adaptação do Sigaa para servir também aos cursos da Sedis passou, entre outras coisas, pelo fato de que, no ensino presencial da UFRN, o aluno deve ser submetido a três avaliações, que geram três notas ao longo do semestre. No entanto, por uma questão de logística, a EaD percebeu a inviabilidade de ter tantas provas, e passou a adotar um modelo com apenas duas $\operatorname{provas}^{40}$. Para o entrevistado B, isto foi importante dentro da Sedis, pois os funcionários dedicavam muito tempo cuidando da geração e da logística das avaliações presenciais.

A UFRN não obriga o professor a dar sempre os mesmos pesos para as atividades presenciais e atividades a distância. Isto significa que, ao mesmo tempo em que um professor, em uma dada disciplina, atribua peso $10 \%$ para as atividades realizadas a distância e $90 \%$ para a avaliação presencial, outro professor pode atribuir $50 \%$ para cada modalidade de atividade. Uma normalização se observa exclusivamente nas disciplinas práticas do curso de Química, normalização esta implantada recentemente para evitar o que, segundo o entrevistado J, vinha

\footnotetext{
${ }^{40}$ Existe, ainda, uma prova final, que pode servir como substitutiva de uma das duas provas já aplicadas, tanto para quem não realizou quanto para quem deseje "aprimorar" a média, quanto pode servir como prova de recuperação, de acordo com o entrevistado B.
} 
ocorrendo com frequência: o baixo comparecimento dos alunos às aulas práticas. De acordo com esta normalização, as disciplinas práticas do curso de Química passam a ter a seguinte composição de notas, na parte da nota atribuída pelo professor: 50\% da nota dada pela avaliação presencial; $40 \%$ da nota atribuída por meio da avaliação dos relatórios de práticas; $10 \%$ dados ao aluno que elabora com competência um relatório denominado "pré-laboratório", que serve para que ele se prepare previamente para a prática que será executada. Em relação àquela que pode ser considerada a última avaliação do curso, o trabalho de conclusão de curso (TCC), as coordenações de curso decidiram cobrar memoriais sobre o período do curso, como equivalentes ao TCC, em lugar deste. Havia, ainda, no caso do curso de Física, a opção de entrega de um artigo ou de um ensaio.

Na UFT, o peso das avaliações é previsto pelo PPC, sendo de $30 \%$ da nota final da disciplina atribuída a atividades realizadas a distância e outros $70 \%$ resultantes de duas avaliações presenciais. O colegiado de Química também buscou estabelecer que um máximo de 30\% da avaliação presencial poderia ser em múltipla escolha, visando a reduzir a possibilidade de fraudes no exame pelo compartilhamento de respostas entre os alunos, algo muito mais fácil em uma prova de múltipla escolha do que dissertativa ou argumentativa. Tais definições não existem no curso de Física, que deixou a critério de cada professor a forma e o peso das avaliações, segundo o entrevistado $\mathrm{W}$.

Quanto à presença dos alunos nos polos da UFRN, esta não é controlada. Em outras palavras, não existe reprovação por frequência. Os tutores, de certa forma, controlam a frequência dos alunos com a sua atribuição de $20 \%$ da nota de cada componente curricular. Este quadro, presente nos cursos da UFRN, em que o professor não consegue estar regularmente presente aos polos e em que o tutor avalia o aluno, levou a universidade potiguar a entender que a presença do aluno no polo é atestada a partir da avaliação executada pelo tutor orientador, uma vez que este não estaria apto a atribuir nota favorável a um aluno sempre ausente. Já que a UFRN não cobra a presença do aluno no polo de forma direta, à exceção dos dias de avaliações presenciais, é sugerido aos professores que elaborem atividades que incentivem a ida do aluno ao polo, como a formação de grupos de estudos. Segundo o entrevistado J, o perfil dos alunos que levam o curso até o fim é o de aluno que frequenta regularmente o polo, participando das atividades propostas. Para o entrevistado J, embora o PPC diga que a presença do aluno no polo deva ser semanal, ela costuma ser quinzenal. Esta presença ocorre para a realização de duas atividades, no caso do curso de Química: entrega dos diários de estágio para o tutor de estágio e realização das práticas de 
laboratório. Outra forma de evitar fraudes é mudar as atividades exigidas dos alunos a cada reoferta da disciplina.

O curso de Química da UFT tem os aspectos discutidos neste tópico entre os que mais receberam atenção por parte do colegiado de curso, como o controle de frequência, a necessidade de encontros presenciais regulares e a padronização de avaliação e de notas. No caso do controle de frequência, este se faz pelos professores participantes dos momentos presenciais do curso em conjunto com os tutores presenciais. $\mathrm{O}$ fato de haver apenas três encontros presenciais por disciplina faz com que tenhamos bom senso na hora de avaliar a frequência. Não houve, até o momento, alunos reprovados unicamente pela frequência, uma vez que os alunos que faltam aos momentos presenciais têm grande dificuldade de realizar a avaliação presencial com sucesso. Em geral, são alunos menos interessados, que, suspeita-se, também não realizaram estudo solitário suficiente. Segundo o entrevistado Z, o curso de Física também vem controlando frequência, embora este entrevistado não soubesse precisar se houve algum aluno reprovado unicamente por frequência em alguma disciplina daquele curso.

Em abril de 2011, ficou definido que, uma vez que os PPC tocantinenses preveem que $25 \%$ da carga horária de cada disciplina sejam presenciais e que a carga horária de quase todas elas é de 60 horas, as 15 horas presenciais deveriam ser divididas da seguinte forma: 4 horas de encontro com a presença do professor; 4 horas de realização de atividade a ser aplicada pelo tutor presencial; 4 horas para avaliação da disciplina; 3 horas livres a serem cumpridas no polo. A demanda dos alunos por mais momentos presenciais era grande, mas não podia ser atendida naquele momento. Após o fỉm das restrições orçamentárias, o colegiado do curso de Química pôde definir aquilo que considerava mais adequado: 8 horas de encontro com a presença do professor; 4 horas de realização de atividade a ser aplicada pelo tutor presencial, a qual deve contar como parte da avaliação presencial; 3 horas para avaliação final da disciplina.

Por outro lado, no curso de Física, não foram tão frequentes os encontros presenciais com os professores, segundo o entrevistado Z. De acordo com este entrevistado, naquele curso, nem todas as disciplinas tiveram encontros presenciais, inexistindo, portanto, uma regra geral sobre a presença dos professores. A necessidade de encontros presenciais regulares consta do PPC, mas não esclarece que os professores devem, também, comparecer a tais encontros. Assim sendo, naquele curso, os alunos foram obrigados a ir todas as semanas ao polo de apoio presencial. No entanto, o que encontravam lá, muitas vezes, eram apenas coisas que não exigiam que tivessem saído de casa, às vezes viajando centenas de quilômetros: aulas via comunicador instantâneo, ministradas pelos professores a partir de Palmas. 
O entrevistado W sugere que esta falta de flexibilidade no controle de frequência dos alunos, aliada a uma ausência de contato presencial com todos os professores, seriam razões para a evasão de alguns dos alunos do curso. Ou seja, esta assimetria na exigência de presença - alunos precisam ir todas as semanas ao polo, professores não precisam - teria desmotivado parte dos alunos. A flexibilidade na presença dos professores, no entanto, também tem aspectos positivos, pois permite uma melhor alocação dos recursos, como diárias e veículos, às disciplinas em que uma maior presença do professor é pedida pelos alunos. Trata-se, portanto, de um ponto potencialmente positivo do curso de Física. Entretanto, não possibilitar ao aluno usufruir da mesma flexibilidade, especialmente em um curso a distância, parece não somente contrassensual, mas também contraproducente, pois impossibilita a alunos com maiores restrições de tempo e dificuldades de deslocamento ao polo o acompanhamento e a continuidade das atividades acadêmicas. 


\section{CONCLUSÕES}

Políticas públicas nacionais vêm direcionando a educação superior a distância, especialmente para servir à formação inicial e continuada de professores, como forma de aumentar a quantidade de professores e a eficiência desta formação. De fato, a EaD permite o atendimento de mais professores com melhor relação eficiência versus custos, utilizando as potencialidades da comunicação em massa e da reduzida demanda por estruturas como salas de aula. Mas a EaD é especialmente importante porque pode manter os professores na ativa, ou seja, além de não precisarem se ausentar da escola, têm potencial para aplicar imediatamente o que aprendem.

Especificamente em relação à política de formação de professores, ela precisa superar a dicotomia entre educação presencial e a distância. Tal política também precisa estar integrada à educação básica e superar o nível de ações setoriais, com programas ou planos nem sempre articulados, para passar a ser uma política, efetivamente, de Estado. A criação do Conselho Técnico-Científico da Educação Básica e do Plano Nacional de Formação de Professores da Educação Básica, o Parfor, ambos na Capes, já indica uma atitude do poder público neste sentido, ainda que tais ações sejam insuficientes, por exemplo, pela pouca estabilidade dos programas e ações propostas pelo Parfor, pois, diferentemente do que ocorre nos cursos presenciais, as ofertas dos cursos são irregulares.

Essa estabilidade é passagem obrigatória quando se pretende garantir a qualidade do ensino, pois tais programas, como todo projeto de educação a distância, precisam de longo tempo de execução para gerar efeitos expressivos e se revelar vantajoso. A insuficiência na integração entre as modalidades presencial e a distância também se nota a partir da relativa desvalorização desta última, como sua exclusão do Programa de Financiamento Estudantil (Fies), ou a dificuldade ou impossibilidade de participação em programas de apoio como o PNAS, o PET e o Pibid. De certa forma, pode-se pensar que a $\mathrm{EaD}$, especialmente na formação de professores, tem sido tratada como de qualidade inferior até mesmo pelo MEC, o que pode vir a constituir um círculo vicioso.

Interpretando o que disseram, por exemplo, os entrevistados D e K, pode-se concluir que os problemas relativos à $\mathrm{EaD}$ pública no Brasil não são conceituais, podendo ser superados com o estabelecimento de rotinas mais estáveis. Afinal, os maiores problemas que o sistema UAB vem enfrentando são devidos ao seu status de programa não institucional, o que torna os fluxos de verbas irregulares e o sistema instável. Isto parece ainda 
particularmente grave em cursos de formação de professores de Ciências, como os estudados nesta tese. Estes demandam mais fortemente a presença dos professores nos polos, bem como uma maior e mais dispendiosa dotação de equipamentos e de materiais de consumo, relacionada à exigência de aulas práticas de laboratório, por exemplo.

Outro ponto nevrálgico do sistema UAB é a falta de comprometimento das entidades estaduais e municipais com os polos, que precisam ser equipados, dotados de recursos humanos e ter manutenção em dia. Nos três estados que visitei, percebi falta de sinergia entre as esferas de governo em absoluto, com consequências especialmente severas quanto à expansão, a manutenção e a estruturação dos polos. Opções que podem ser consideradas para a solução destes problemas são a articulação dos cursos EaD com as ações estaduais e municipais para a formação de professores, a destinação obrigatória de uma fatia dos recursos do Fundeb para a estruturação e a manutenção dos polos e a transferência da gestão dos polos dos entes federativos para as universidades.

Revisitando alguns dos objetivos específicos propostos para este trabalho, vemos problemas semelhantes que surgiram em circunstâncias distintas. Embora o perfil de alunos, tutores e professores seja razoavelmente distinto entre a UFRN e a UFT, assim como o sistema de avaliação, de tutoria, de encontros presenciais e de uso do ambiente virtual também tenha diferenças, diversos dos problemas são comuns. Em ambos os cursos, de ambas as universidades, persistem altas taxas de evasão e de reprovação e pouca dedicação dos alunos ao estudo por um tempo mínimo necessário ao aprendizado. Tudo isto requer mais estudos e novas propostas de abordagem dos problemas, situando-se, portanto, entre as questões a investigar em futuras pesquisas acadêmicas, mas, independentemente disso, cabe um alerta aos gestores dos cursos e do sistema UAB. Por outro lado, a necessidade de abertura de novas turmas, especialmente no Tocantins, é premente, dado o enorme déficit de professores licenciados nas áreas científicas atuando nas escolas públicas.

Altas taxas de evasão são comuns na formação de professores, mesmo em cursos presenciais, mas parecem ser exacerbadas na EaD. Entre outras razões, isto se deve ao perfil diferenciado dos alunos nessa modalidade, mais velhos, muitas vezes já detentores de outros títulos e, não raro, já exercendo a profissão. Se não se tem controle dos fatores de evasão externos aos cursos, é justo enfrentar o desafio de buscar reverter a lógica da evasão motivada por fatores internos aos cursos e devidos à própria natureza da modalidade. Afinal, como já havia notado Belloni (2003), os profissionais que mais se beneficiam dos programas de formação de professores a distância são aqueles que menos necessitam deles, por serem os mais preparados para o estudo solitário interativo, enquanto aqueles que precisam mais e que 
são o público prioritário da $\mathrm{EaD}$, não estão, em sua maioria, preparados para a leitura crítica das mensagens contidas nos objetos de aprendizagem em $\mathrm{EaD}$, o que é fator de evasão.

Uma conquista parece que já foi alcançada nos cursos da UFT: os alunos que permanecem no curso, ainda que sejam os mais interessados, não eram os mais capacitados a ser autodidatas. Parece-me uma chance única de mostrar que é possível desvincular a EaD de um "talento" inato ligado ao estudo solitário, desde que haja estímulos suficientes e adequados. $\mathrm{O}$ entrevistado $\mathrm{J}$, por exemplo, define o papel de coordenador de curso em EaD como semelhante ao de um fazendeiro trazendo o rebanho, especialmente ao relatar o controle de reofertas de disciplinas e as tentativas de conter a evasão. Talvez a mudança deste tipo de percepção, de alunos vistos como gado, para uma compreensão dos educandos como interlocutores centrais, sujeitos e objetos de um constante e profícuo diálogo, leve a uma melhora nos índices de controle de evasão e de desempenho acadêmico.

Entre as especificidades dos cursos de formação de professores de Física e de Química em relação aos demais cursos de graduação na modalidade de EaD, podem ser apontadas em particular:

- a exigência de laboratórios, sem os quais uma formação para a experimentação não seria efetivada, e em relação a que levantei propostas para reduzir o custo e a demanda, permitindo uma maior interiorização destes cursos;

- a necessidade de uma abordagem de uma "Instrumentação para o Ensino de Ciências" que vá além de uma rotineira "Metodologia para o Ensino", especialmente se considerarmos os PPC examinados, que propõem uma abordagem dialógica, contextualizada no cotidiano do aluno;

- $\quad$ a importância de atenção especial ao ensino de disciplinas como Cálculo, Física Geral e Química Geral, para que o sistema de pré-requisitos nestes componentes curriculares não contribua para a taxa de reprovação, que costuma ser alta mesmo em cursos presenciais e, por conseguinte, para as taxas de evasão.

Estes são alguns dos elementos que devem ser considerados para uma reorientação das práticas dos diversos atores do sistema, constituindo uma advertência ou recomendação especial para gestores e coordenadores que, não sendo da área do ensino de Ciências, possam estar eventualmente desatentos relativamente a essas características.

$\mathrm{O}$ referencial freireano mostrou-se especialmente adequado para $\mathrm{a} \mathrm{ED}$, à medida que enfatiza a abertura ao diálogo, normalmente difícil e reduzido em cursos que enfatizam o estudo solitário. Além de ter sido bem-sucedida a nossa busca por um tema gerador de relevância para a realidade do Tocantins, observei, ao longo do processo, a mudança de 
pensamento e de atitude nos próprios professores dos cursos, à medida que tiveram uma nova visão do projeto pedagógico do curso, e passaram a defendê-lo com mais ênfase do que inicialmente, especialmente durante a confecção do material didático complementar.

A primeira entrevista realizada na UFT já mostrou o potencial reflexivo, crítico e evolutivo de um trabalho como este, de interlocução direta e franca: iniciei a conversa acreditando que só cumpriria uma etapa da tese, mas, ao fim do diálogo, ficou claro que os dois, entrevistador e entrevistado, aprenderam ainda mais um sobre o trabalho do outro, sobre o olhar que o outro tem do passado, do presente e do futuro do curso, e sobre como podemos trabalhar para fazer deste um curso ainda melhor. A abertura ao diálogo e a gestão participativa, características cada vez mais presentes na UFT, especialmente no curso de Química, não somente tornaram o curso mais democrático, como também o fizeram mais coerente com o projeto pedagógico. Se o começo do curso foi difícil para os envolvidos, hoje são discutidos diversos temas educacionais com mais profundidade e solidez argumentativa em reuniões de colegiado de curso, a despeito de grande parte dos membros não serem pesquisadores da área de educação e de ensino de Ciências.

Surgiram problemas, como o excesso de importância dado por alguns dos professores às suas áreas de especialidade, em detrimento do que seria desejável promover para que o aluno estivesse mais aparelhado para enfrentar o cotidiano de seu ofício. De fato, professores continuam mais atentos a interesses particulares ligados a suas respectivas áreas de formação e de atuação, mas a maioria deles e dos gestores dos cursos já está mais atenta ao PPC do que antes, especialmente à medida que se vê mais envolvida com o curso e com a dinâmica da $\mathrm{EaD}$ e com os objetivos do sistema UAB. Estes professores e gestores parecem, sim, ter adquirido a visão essencial de que a EaD permite a mais estudantes o acesso ao ensino superior, especialmente os de locais distantes dos núcleos urbanos, sem estrutura universitária convencional, ou aqueles cujo tempo e agenda são incompatíveis com os dos cursos presenciais.

Ao mesmo tempo em que os cursos da UFT ainda podem se beneficiar muito com o conhecimento obtido por outras universidades, a experiência tocantinense também tem características que poderiam ser estendidas a outros cursos. Por exemplo, da UFRN tomamos a proposta de criação do ambiente virtual coletivo da coordenação de curso para discussão, ambiente que foi vital para o crescimento do diálogo entre coordenação e os demais atores, assim como a valorização dos tutores presenciais em relação aos tutores a distância. Da mesma forma, a partir das entrevistas e dos levantamentos bibliográficos, foi possível ver que a experiência da UFT também tem características particulares reprodutíveis em outros cursos 
UAB, como o colegiado plenamente participativo e os momentos presenciais com cada um dos professores de disciplina em todos os polos.

Esse intercâmbio de experiências, numa interação maior entre as universidades, é recomendável, seja a partir de contribuições bilaterais, como a promovida entre a UFRN e a UFT, seja em reuniões coletivas realizadas na Capes entre os coordenadores de cursos. Nesse sentido, no que diz respeito ao trabalho das coordenações de curso, foi preocupante a escassez das reuniões na Capes desde o início de 2011, processo que parece começar a ser revertido neste segundo semestre de 2012. A falta de comunicação direta entre coordenadores de curso, assim como entre esses e a Capes, pode permitir a cristalização de práticas ineficazes e, ao mesmo tempo, dificultar a divulgação das boas práticas em EaD no âmbito do sistema UAB.

Ao longo do trabalho, cresceram diversos questionamentos para futuras investigações. Saviani (2011) aponta para a falência do modelo de formação de professores sem prévio preparo para as atividades práticas da docência, que geraria uma sensação de desamparo nos docentes iniciantes, em relatos que não se limitariam ao Brasil. O caminho para o preparo pedagógico do docente em formação inicial universitária é o estágio curricular obrigatório, o qual, nessa visão, não pode ser meramente de observação, mas também de intervenção e de regência, devidamente orientada, acompanhada, corrigida, adequada, repetida.

Nesta linha, a perspectiva de criação da função do coordenador de estágio, remunerada por bolsa no âmbito de cada curso do sistema, coincidindo com o início dos estágios dos cursos da UFT, indica um possível rumo para futuras pesquisas acadêmicas. Nestas investigações, o conhecimento dos atores e dos processos, como descritos e analisados nesta tese, servirá de alicerce para um olhar crítico acerca da construção da formação prática dos alunos dos cursos tocantinenses. O desafio é imenso. Afinal, concordando com Saviani (2011), se o funcionamento das escolas é precário, os estágios nelas realizados também serão precários, especialmente pela falta de professores habilitados para seu acompanhamento.

Em síntese extrema das conclusões desta tese, sinalizo que, para se consolidar a formação de professores na modalidade a distância, ou seja, sua manutenção e expansão, além de regularidade no financiamento e na oferta, é essencial, no atual formato do sistema UAB, o estabelecimento de uma sinergia, fundada em envolvimento pactuado entre os diversos níveis de governo e as universidades, de forma a haver constante apoio institucional. Também aponto que é preciso haver sintonia entre o projeto pedagógico e o tipo de professor que se busca formar, assim como garantir recursos humanos e materiais para a formação, como corpo docente e de tutores contratados para o sistema, laboratórios operantes, atividades 
culturais, boas condições para a realização de estágios nas escolas, programas permanentes de bolsas de inclusão social e de excelência acadêmica.

As conclusões aqui contidas podem ser generalizadas para ambientes similares, permitindo orientações de políticas públicas concebidas com o objetivo de mitigar a reconhecida carência de professores, particularmente nas áreas científicas. Também podem contribuir para ampliar o conhecimento dos atores do sistema UAB sobre a própria prática a partir dos aspectos aqui levantados, explicitando suas realizações e possibilitando uma reorientação de suas expectativas. 


\section{REFERÊECIAS ${ }^{*}$}

ADEM, Awol Endris. Teacher training through distance education: ICCBA's experience. Africa Educational Review, v.6, n.1, p.174-184, 2009.

ADORNO, Theodor W. Educação e emancipação. São Paulo: Paz e Terra, 1995.

ALBUQUERQUE, Teresa. Formaturas do Grupo II emocionam participantes. ProInformação: boletim trimestral do Programa de Formação de Professores em Exercício, Brasília, v.2, n.6, p.2, 2002. Disponível em: <http:// proformacao. proinfo. mec. gov. br/ pdf/ jornal6. pdf>. Acesso em: 27 maio 2010.

ALDEIA, Mónica. A formação de professores a distância na construção de comunidades educativas. Aveiro (Portugal): Prof2000, [2003?]. Disponível em: <http:// www. prof2000. pt/ p2000/ artigos. asp ?ID=22>. Acesso em: 27 maio 2010.

ALMEIDA, Fernando José de. Educação e informática: os computadores na escola. 4.ed. São Paulo: Cortez, 2009.

ALMEIDA, Mariana Carla de. Estudo da usabilidade da interface do ambiente virtual de aprendizagem da Unitins. 2009. 224 f. Dissertação (Mestrado em Educação). Faculdade de Educação da Universidade de Brasília, Brasília, 2009.

ALONSO, Kátia Morosov. Novas tecnologias e formação de professores: Um intento de compreensão. In: REUNIÃO ANUAL DA ASSOCIAÇÃO NACIONAL DE PÓS-GRADUAÇÃO E PESQUISA EM EDUCAÇÃO, 22., 1999, Caxambu, MG. Anais... Rio de Janeiro: Associação Nacional de Pós-Graduação e Pesquisa em Educação, 1999.

A expansão do ensino superior no Brasil e a EaD: dinâmicas e lugares. Educação \& Sociedade, Campinas, v.31, n.113, p.1319-1335, out./dez.2010.

AMBIENTE DE TRABALHO DA UAB. Primeira Reunião de Orientadores Acadêmicos do Estado do Pará. Disponível em: <http:// www. uab. capes. gov. br/ atuab>. Acesso em: 18 mar. 2010.

ANFOPE Associação Nacional pela Formação dos Profissionais da Educação. Contribuições para subsidiar discussão na audiência pública nacional/CNE sobre a proposta de diretrizes para a formação inicial de professores da educação básica, em cursos de nível superior. 23 abr.2001. Disponível em: <http:// portal. mec. gov. br/ cne/ arquivos/ pdf/ ANFOPE.pdf>. Acesso em: 12 fev.2012.

ANGOTTI, José André Peres. Solução alternativa para a formação de professores de Ciências: um projeto educacional desenvolvido na Guiné Bissau. 188 f. 1982. Dissertação (Mestrado em Educação). Faculdade de Educação da Universidade de São Paulo, São Paulo, 1982.

\footnotetext{
* De acordo com:

ASSOCIAÇÃO BRASILEIRA DE NORMAS TÉCNICAS. NBR 6023: informação e documentação: referências: elaboração. Rio de Janeiro, 2002.
} 
Fragmentos e totalidades no conhecimento científico e no ensino de ciências. 1991. 233 f. Tese (Doutorado em Educação). Faculdade de Educação da Universidade de São Paulo, São Paulo, 1991.

Desafios para a formação presencial e a distância do físico educador. Revista Brasileira de Ensino de Física, v.28, n.2, p.143-150, 2006.

ARAÚJO, Nataniel da Vera-Cruz Gonçalves. O normal superior telepresencial e a trilogia: política educacional, formação de professoras(es) e educação a distância. $2008.136 \mathrm{f}$. Dissertação (Mestrado em Educação). Universidade Federal do Maranhão, São Luís, 2008.

BARRETO, Elba Siqueira de Sá. Capacitação a distância de professores do ensino fundamental no Brasil. Educação \& Sociedade, Campinas, v.18, n.59, p.308-329, ago.1997.

BARRETO, Lina Sandra. Educação a distância: perspectiva histórica. Revista Estudos (Abmes), Brasília, n.26, jun.1999. Disponível em: <http:// www. abmes. org. br/ Publicacoes/ Estudos/ 26/ lina. htm>. Acesso em: 27 jul. 2010.

BARRETO, Raquel Goulart. Tecnologias na formação de professores: o discurso do MEC. Educação e Pesquisa, São Paulo, v.29, n.2, p.271-286, jul./dez.2003.

Tecnologia e educação: trabalho e formação docente. Educação \& Sociedade, Campinas, v.25, n.89, p.1181-1201, set./dez.2004.

A formação de professores a distância como estratégia de expansão do ensino superior. Educação \& Sociedade, Campinas, v.31, n.113, p.1299-1318, out./dez.2010.

BASTOS, Philipe. Siqueira Campos vence Gaguim e chega pela $4^{a}$ vez ao governo do Tocantins. Conexão Tocantins. 03 out.2010. Disponível em: <http:// conexaoto. com. br/ 2010/ 10/ 03/ siqueira- campos- vence- gaguim- e- chega- pela- 4a- vez- ao- governo- dotocantins>. Acesso em: 13 fev.2011.

BATES, Anthony (Tony) W. Distance education in dual mode higher education institutions: challenges and changes. E-Learning and Distance Education Resources. The University of British Columbia, 2000. Disponível em: <http:// bates. cstudies. ubc. ca/ papers/ challengesandchanges. html>. Acesso em: 28 jul.2010.

Distance education for teaching training in Africa. E-Learning and Distant Education Resources. 29 mar. 2010. <http:// www. tonybates. ca/ 2010/ 03/ 29/ distanceeducation- for- teacher- training- in- africa>. Acesso em 23 jan. 2011.

BAUDRILLARD, Jean. A transparência do mal: ensaio sobre os fenômenos extremos. 7.ed. Campinas: Papirus, 2003.

BELLONI, Maria Luiza. Educação a distância. Campinas: Autores Associados, 2001.

Ensaio sobre a educação a distância no Brasil. Educação \& Sociedade, Campinas, v.23, n.78, p.117-142, abr.2002.

A televisão como ferramenta pedagógica na formação de professores. Educação e Pesquisa, São Paulo, v.29, n.2, p.287-301, jul./dez.2003. 
BERNSTEIN, Basil. A estruturação do discurso pedagógico: classe, códigos e controle. Petrópolis: Vozes, 1996.

BIELSCHOWSKY, Carlos Eduardo. Mensagem à comunidade de educação a distância. Brasília, DF, 5 jan.2011. Disponível em: <http:// ead. folhadirigida. com. br/ ?p= 4346>. Acesso em: 18 maio 2011.

BRAGA, Ana Lúcia; BUENO, José de França. Avaliação da produção escrita em disciplinas de ciências exatas no nível superior. In: CONGRESSO INTERNACIONAL ABED DE EDUCAÇÃO A DISTÂNCIA, 15., 2009, Fortaleza. Trabalhos científicos... São Paulo: Associação Brasileira de Pesquisa em Educação em Ciências, 2009. Disponível em: <http:// www. abed. org. br/ congresso2009>. Acesso em: 17 jul.2012.

BRASIL. Constituição da República Federativa do Brasil (1988). Brasília, DF: Assembleia Nacional Constituinte, 1988.

Justiça Federal de $1^{a}$ Instância. Seção Judiciária do Estado do Tocantins. Primeira Vara. Decisão Interlocutória. Cautelar Inominada. Demandante: Sociedade Civil de Educação Continuada Ltda. Demandado: União, Fundação Universidade do Tocantins e Ministério Público Federal. 2008. Disponível em: <http:// www. ogirassol. com. br/ pagina. php? idnoticia $=6253>$. Acesso em: 10 maio 2011.

Ministério da Educação. Perguntas \& Respostas TAC Unitins. Brasília, DF: Ministério da Educação, 2009. Disponível em: <http:// ava2. unitins. br/ ava/ Arquivos/ faq_tac. pdf>. Acesso em: 15 maio 2011.

Decreto Federal $n^{\circ} 5622$, de 19 de dezembro de 2005. Regulamenta o art. 80 da Lei $\mathrm{n}^{\text {o }}$ 9394, de 20 de dezembro de 1996, que estabelece as diretrizes e bases da educação nacional. Diário Oficial da União, Brasília, DF, 20 dez. 2005. Seção 1.

Decreto Federal n ${ }^{\circ} 5773$, de 9 de maio de 2006. Dispõe sobre o exercício das funções de regulação, supervisão e avaliação de instituições de educação superior e cursos superiores de graduação e sequenciais no sistema federal de ensino. Diário Oficial da União, Brasília, DF, 10 maio 2006. Seção 1.

Decreto Federal $\mathrm{n}^{\mathrm{o}}$ 5800, de 8 de junho de 2006. Dispõe sobre o Sistema Universidade Aberta do Brasil. Diário Oficial da União, Brasília, DF, 9 jun. 2006. Seção 1.

Decreto Federal $\mathrm{n}^{\circ}$ 6303, de 12 de dezembro de 2007. Altera dispositivos dos Decretos nos 5.622, de 19 de dezembro de 2005, que estabelece as diretrizes e bases da educação nacional, e 5.773, de 9 de maio de 2006, que dispõe sobre o exercício das funções de regulação, supervisão e avaliação de instituições de educação superior e cursos superiores de graduação e sequenciais no sistema federal de ensino. Diário Oficial da União, Brasília, DF, 13 dez. 2007. Seção 1.

Decreto Federal no 6755, de 29 de janeiro de 2009. Institui a Política Nacional de Formação de Profissionais do Magistério da Educação Básica, disciplina a atuação da Coordenação de Aperfeiçoamento de Pessoal de Nível Superior -Capes no fomento a programas de formação inicial e continuada, e dá outras providências. Diário Oficial da União, Brasília, DF, 30 jan. 2009. Seção 1. 
Lei Federal no 8405, de 9 de janeiro de 1992. Autoriza o Poder Executivo a instituir como fundação pública a Coordenação de Aperfeiçoamento de Pessoal de Nível Superior (Capes) e dá outras providências. Diário Oficial da União, Brasília, DF, 10 jan. 1992. Seção 1.

Lei Federal no 9394, de 20 de dezembro de 1996. Estabelece as diretrizes e bases da educação nacional. Diário Oficial da União, Brasília, DF, 23 dez. 1996. Seção 1.

Lei Federal no 10172, de 9 de janeiro de 2001. Aprova o Plano Nacional de Educação e dá outras providências. Diário Oficial da União, Brasília, DF, 10 jan. 2001. Seção 1.

Lei Federal no 11502, de 11 de julho de 2007. Modifica as competências e a estrutura organizacional da fundação CAPES. Diário Oficial da União, Brasília, DF, 12 jul. 2007. Seção 1.

Lei Federal $n^{\circ} 11892$, de 29 de dezembro de 2008. Institui a Rede Federal de Educação Profissional, Científica e Tecnológica, cria os Institutos Federais de Educação, Ciência e Tecnologia, e dá outras providências. Diário Oficial da União, Brasília, DF, 30 dez. 2008. Seção 1.

. Ministério da Educação. Portaria n ${ }^{\circ} 2253$, de 18 de outubro de 2001. Permite oferta de disciplinas que, em seu todo ou em parte, utilizem método não presencial. Diário Oficial da União, Brasília, DF, 19 out. 2001. Seção 1.

Ministério da Educação. Portaria n ${ }^{\circ}$ 2145, de 16 de julho de 2004. Credencia, pelo prazo de 5 (cinco) anos, a Universidade do Tocantins - UNITINS, mantida pela Fundação Universidade do Tocantins, ambas com sede na cidade de Palmas, estado do Tocantins, para a oferta de cursos de graduação a distância. Diário Oficial da União, Brasília, DF, 20 jul. 2004. Seção 1.

Ministério da Educação. Portaria no 4059, de 10 de dezembro de 2004. Autoriza a inclusão de disciplinas não presenciais em cursos superiores reconhecidos. Diário Oficial da União, Brasília, DF, 13 dez.2004. Seção 1.

Ministério da Educação. Portaria $n^{\circ} 873$, de 7 de abril de 2006. Autoriza, em caráter experimental, a oferta de cursos superiores a distância nas Instituições Federais de Ensino Superior. Diário Oficial da União, Brasília, DF, 11 abr.2006. Seção 1.

Ministério da Educação. Portaria $n^{\circ} 44$, de 18 de agosto de 2009. Descredencia a Universidade do Tocantins. Diário Oficial da União, Brasília, DF, 19 ago.2009. Seção 1, p.16.

Ministério da Educação. Portaria n ${ }^{\circ}$ 1326, de 18 de novembro de 2010. Aprova, em extrato, o Instrumento de Avaliação de Cursos de Graduação: Bacharelados e Licenciatura, na modalidade de educação a distância, do Sistema Nacional de Avaliação da Educação Superior - SINAES. Diário Oficial da União, Brasília, DF, 19 nov.2010. Seção 1.

Ministério da Educação. Portaria Normativa n ${ }^{\circ}$ 40, de 12 de dezembro de 2007. Institui o e-MEC, sistema eletrônico de gerenciamento de informações relativas aos processos de regulação, avaliação e supervisão da educação superior federal, e o Cadastro e-MEC de Instituições e Cursos Superiores, consolida disposições sobre indicadores de qualidade, e outras disposições. Diário Oficial da União, Brasília, DF, 29 dez.2010. Seção 1. 
BRITO, Ana Cristina Facundo de; GOMES, Apuena Vieira; FERNANDES, Joana D'Arc Gomes. Perfil dos alunos da primeira turma de alunos do curso de licenciatura em Química em educação a distância da UFRN. In: CONGRESSO INTERNACIONAL ABED DE EDUCAÇÃ̃O A DISTÂNCIA, 15., 2009, Fortaleza. Trabalhos científicos... São Paulo: Associação Brasileira de Pesquisa em Educação em Ciências, 2009. Disponível em: <http:// www. abed. org. br/ congresso2009>. Acesso em: 17 jul.2012.

CARVAlHO, Anna Maria Pessoa de; GIL-PÉREZ, Daniel. Formação de professores de Ciências: tendências e inovações. 10.ed. São Paulo: Cortez, 2011.

CASTRO, Claudio de Moura; CARNOY, Martín (Orgs.) Como anda a reforma da educação na América Latina? Rio de Janeiro: Fundação Getúlio Vargas, 1997.

CENTRO DE ENSINO SUPERIOR DO SERIDÓ. Projeto Político-Pedagógico do curso de Matemática Ceres-UFRN. Histórico do curso. 2002. Disponível em: <http:// www. cerescaico. ufrn. br/ matematica/ historico. htm>. Acesso em: 23 jan.2012.

CONAE CONFERÊNCIA NACIONAL DE EDUCAÇÃO, 2010, Brasília. Construindo o Sistema Nacional Articulado de Educação: o Plano Nacional de Educação, diretrizes e estratégias de ação. Brasília: Ministério da Educação, 2010.

CONSELHO NACIONAL DE EDUCAÇÃO (Brasil). Recurso contra decisões do Secretário de Educação a Distância que determinaram medidas cautelares relativas à oferta de cursos superiores na modalidade à distância pela Universidade do Tocantins e o descredenciamento da Instituição para esta modalidade. 2009. Disponível em: <http:// portal. mec. gov. br/ index. php? option $=$ com_docman $\&$ task $=$ doc_download $\&$ gid $=1617 \&$ Itemid=>. Acesso em: 10 maio 2011.

CONSÓRCIO DE EDUCAÇÃO SUPERIOR A DISTÂNCIA DO ESTADO DO RIO DE JANEIRO. Disponível em: <http://www.cederj.edu.br>. Acesso em: 16 jul. 2012.

COORDENAÇÃO DE APERFEIÇOAMENTO DE PESSOAL DE NÍVEL SUPERIOR. Programa de Qualificação de Docente e Ensino de Língua Portuguesa no Timor-Leste. Disponível em: <http:// www. capes. gov. br/ cooperacao- internacional/ timor- leste>. Acesso em: 05 fev.2012.

CORTELLA, Mario Sergio. A reconstrução da escola (a educação municipal em São Paulo de 1989 a 1991). Em Aberto, Brasília, v.11, n.53, p.54-63, jan./mar.1992.

COSTA, Celso José da; DURAN, Maria Renata da Cruz. A política nacional de formação de professores entre 2005 e 2010: a nova Capes e o sistema Universidade Aberta do Brasil. Revista Brasileira de Pós-Graduação, Brasília, v.9, n.16, p.263-313, abr.2012.

COX, Kenia Kodel. Informática na educação escolar. 2.ed. Campinas, SP: Autores Associados, 2008.

CUNHA, Silvio Luiz Souza. Reflexões sobre o EAD no Ensino de Física. Revista Brasileira de Ensino de Física, v.28, n.2, p.151-153, 2006.

CURSO a distância da USP tem 40\% de evasão. Folha.com. Ago.2011. Disponível em: $<\mathrm{http}$ // www1. folha. uol. com. br/ saber/ 965112-curso-a-distancia-da-usp-tem-40-deevasao.shtml>. Acesso em: 9 jan.2012. 
DEL CARLO, Sandra. Duas propostas de ensino de segundo grau e suas formas de compreender a eletricidade. 1997. 126 f. Dissertação (Mestrado em Ensino de Ciências). Instituto de Física e Faculdade de Educação da Universidade de São Paulo, São Paulo, 1997.

DELIZOICOV Neto, Demétrio. Concepção problematizadora para o ensino de ciências na educação formal: relato e análise de uma prática educacional na Guiné-Bissau. 1982. 227 f. Dissertação (Mestrado em Ensino de Ciências). Instituto de Física e Faculdade de Educação da Universidade de São Paulo, São Paulo, 1982.

Conhecimento, tensões e transições. 1991. 214 f. Tese (Doutorado em Educação). Faculdade de Educação da Universidade de São Paulo, São Paulo, 1991.

DELIZOICOV, Demétrio; ANGOTTI, José André. Metodologia do ensino de ciências. São Paulo: Cortez, 1990.

DELIZOICOV, Demétrio; ANGOTTI, José André; PERNAMBUCO, Marta Maria. Ensino de Ciências: fundamentos e métodos. 2.ed. São Paulo: Cortez, 2007.

DESLANDES, Keila; MENDES, Antônio Sérgio. Formação superior de professores a distância: uma análise do uso do meio impresso. In: CONGRESSO INTERNACIONAL DE QUALIDADE EM EAD, 2005, São Leopoldo. Trabalhos... São Leopoldo: Universidade do Vale do Rio dos Sinos, 2005. Disponível em: <http:// www. ricesu. com. br/ ciqead2005/ trabalhos/ 23. pdf>. Acesso em: 27 jul.2012.

DOBES, Cantalícia Elaine Ibarra. Educação superior a distância: uma experiência da Universidade Federal de Santa Catarina. In: COLOQUIO DE GESTIÓN UNIVERSITARIA EN AMÉRICA DEL SUR, 3., 2003, Buenos Aires. Trabajos... Buenos Aires: Universidad Nacional de San Luis, 2003. Disponível em: <http:// rapes. unsl. edu. ar/ Congresos_ realizados/ Congresos/ III\%20Encuentro/ Completos/ IBARRA.pdf>. Acesso em: 27 jul.2010.

DOTTA, Sílvia; GIORDAN, Marcelo. Tutoria em educação a distância: um processo dialógico. In: ENCONTRO INTERNACIONAL VIRTUAL EDUCA BRASIL, 8., 2007, São José dos Campos. Atas.... São José dos Campos: Associação Virtual Educa Brasil, 2007. Disponível em: <http:// quimica. fe. usp. br/ textos/ tics/ ticspdf/ dotta_giordan_VE_2007. pdf $>$. Acesso em: 17 jul.2012.

DOUGIAMAS, Martin. Home Page. Disponível em: <http://www.dougiamas.com>. Acesso em: 28 jun.2010.

DOURADO, Luiz Fernandes. Políticas e gestão da educação superior a distância: novos marcos regulatórios? Educação \& Sociedade, Campinas, v.29, n.104 especial, p.891-917, out.2008.

DOWBOR, Ladislau. Tecnologias do conhecimento: os desafios da educação. 4.ed. Petrópolis: Vozes, 2008.

Ladislau. Título. ComCiência, Campinas, n.101, jun. 2010. Disponível em: <http:// www. comciencia. br/ comciencia/ ?section=8 \&edicao=57 \&id=727>. Acesso em: 27 jun. 2010.

DRUCKER, Peter Ferdinand. Sociedade pós-capitalista. 6.ed. São Paulo: Pioneira, 1997. 
Administrando em tempos de grandes mudanças. 5.ed. São Paulo: Pioneira, 1998.

ELIASQUEVICI, Marianne Kogut; PRADO JÚNIOR, Arnaldo Corrêa. O papel da incerteza no planejamento de sistemas de educação a distância. Educação e Pesquisa, v.34, n.2, p.309325 , maio/ago.2008.

ELLIOTT, John. La investigación-acción en educación. 4.ed. Madrid: Morata, 2000.

FERNANDES, Geraldo Wellington Rocha. Práticas pedagógicas mediatizadas: delineando caminhos para a formação de professores de Física na modalidade a distância. 2007. 239 f. Dissertação (Mestrado em Educação Científica e Tecnológica). Universidade Federal de Santa Catarina, Florianópolis, 2007.

FERNANDES, Geraldo Wellington Rocha; ANGOTTI, José André Peres. Formando professores de Física a distância: repensando o material didático. In: ENCONTRO DE PESQUISA EM ENSINO DE FÍSICA, 10., 2006, Londrina. Atas.... São Paulo: Sociedade Brasileira de Física, 2006. Disponível em: <http:// www. sbf1. sbfisica. org. br/ eventos/ epef/ $\mathrm{x} /$ atas/ resumos/ T0064-1. pdf>. Acesso em: 17 jul.2012.

FERRARI, Paulo Celso; ANGOTTI, José André Peres; TRAGTENBERG, Marcelo Henrique Romano. Educação problematizadora a distância para a inserção de temas contemporâneos na formação docente: uma introdução à Teoria do Caos. Ciência \& Educação, Bauru, v.15, n.1, p.85-104, 2009.

FLORES, Kátia Maia. Histórico do sistema UAB e da EaD. In: (org.). Oferta de curso na modalidade a distância na UFT e formação de tutores para atuar em EaD. Palmas: DTE-UFT, 2010.

FRAENKEL, Jack R.; WALLEN, Norman E. How to design and evaluate research in Education. New York: McGraw Hill, 2009.

FRANÇA, George. Os ambientes de aprendizagem na época da hipermídia e da educação a distância. Perspectivas em Ciência da Informação, v.14, n.1, p.55-65, jan./abr.2009.

FREIRE, Paulo. Ação cultural para a liberdade e outros escritos. 14 ed. São Paulo: Paz e Terra, 2011.

Conscientização: teoria e prática da libertação. São Paulo: Centauro, 2005 b.

Educação como prática da liberdade. São Paulo: Paz e Terra, 2009.

Educação e mudança. 30.ed. Rio de Janeiro: Paz e Terra, 2007.

Extensão ou comunicação? 12.ed. Rio de Janeiro: Paz e Terra, 1977. Terra, 1996.

Pedagogia da autonomia: saberes necessários à prática educativa. São Paulo: Paz e Pedagogia do oprimido. Rio de Janeiro: Paz e Terra, 2005a.

FREITAS, Dirce Nei Teixeira de. A gestão educacional na interseção das políticas federal e municipal. Revista da Faculdade de Educação, São Paulo, v.24, n.2, p.29-50, jul./dez.1998. 
FREITAS, Helena Costa Lopes de. A (nova) política de formação de professores: a prioridade postergada. Educação \& Sociedade, Campinas, v.28, n.100 especial, p.1203-1230, out.2007.

GEREMIAS, Bethânia Medeiros; CIMA, Vanderlei André; ANGOTTI, José André Peres. Contribuições dos meios tecnológicos-comunicativos para o ensino de ciências. In: ENCONTRO NACIONAL DE PESQUISA EM EDUCAÇÃO EM CIÊNCIAS, 5., 2005, Bauru. Atas.... Bauru: Associação Brasileira de Pesquisa em Educação em Ciências, 2005. Disponível em: <http:// www. nutes. ufrj. br/ abrapec/ venpec/ conteudo/ index. htm>. Acesso em: 17 jul.2012.

GERMANO, Auta Stella de Medeiros. Uma análise do formato do estágio nas licenciaturas a distância da UFRN. In: CONGRESSO INTERNACIONAL ABED DE EDUCAÇÃO A DISTÂNCIA, 15., 2009, Fortaleza. Trabalhos científicos... São Paulo: Associação Brasileira de Pesquisa em Educação em Ciências, 2009. Disponível em: <http:// www. abed. org. br/ congresso2009>. Acesso em: 17 jul.2012.

GERMANO, José Willington. As quarenta horas de Angicos. Educação \& Sociedade, Campinas, v.18, n.59, p.389-393, ago.1997.

GIOLO, Jaime. A educação a distância e a formação de professores. Educação \& Sociedade, Campinas, v.29, n.105, p.1211-1234, set./dez.2008.

Educação a distância: tensões entre o público e o privado. Educação \& Sociedade, Campinas, v.31, n.113, p.1271-1298, out./dez.2010.

GIORDAN, Marcelo. O papel da experimentação no ensino de ciências. Química Nova na Escola, n.10, p.43-49, nov.1999.

O computador na educação em ciências: breve revisão crítica acerca de algumas formas de utilização. Ciência \& Educação, v.11, n.2, p.279-304, 2005.

GIORDAN, Marcelo; GÓIS, Jackson. Telemática educacional e ensino de química: considerações em torno do desenvolvimento de um construtor de objetos moleculares. Revista Latinoamericana de Tecnología Educativa (España), v.3, n.2, p.41-59, 2004.

GIORDAN, Marcelo; GOIS, Jackson. Entornos virtuales de aprendizaje en química: una revisión de la literatura. Educación Química (México), v.20, n.3, p.301-313, jul.2009.

GOUVÊA, Guaracira; OLIVEIRA, Carmen Irene. Educação a distância na formação de professores. Rio de Janeiro: Vieira\&Lent, 2006.

HORTON, William Kendall. Designing web-based training: how to teach anyone, anything, anywhere, anytime. New York: Wiley, 2000.

INSTITUTO NACIONAL DE ESTUDOS E PESQUISAS EDUCACIONAIS ANISIO TEIXEIRA. Censo da Educação Superior 2010. Brasília: Inep, 2011a. Disponível em: <http:// download. inep. gov. br/ educacao_ superior/ censo_ superior/ documentos/ 2010/ divulgacao_censo_2010. pdf>. Acesso em: $10 \mathrm{fev} .2012$.

Brasília: Ministério da Educação, 2011b. Página do Instituto Nacional de Estudos e Pesquisas Educacionais Anísio Teixeira. Sinopses estatísticas da educação básica. 
Disponível em: <http:// www. inep. gov. br/ download/ censo/ 2009/ sinopse_ professor_ 09. zip>. Acesso em: 27 fev. 2011.

KENSKI, Vani Moreira. Apresentação. Educação e Pesquisa, São Paulo, v.29, n.2, p.267$-270,2003$.

Educação e comunicação: interconexões e convergências. Educação \& Sociedade, Campinas, v.29, n.104, p.647-665, out.2008.

Tecnologias e ensino presencial e a distância. 7.ed. Campinas, SP: Papirus, 2009.

LACERDA NETO, Jurandyr Carneiro Nobre de; SILVA, Dirceu da. Ensino de tecnologia: uma investigação em sala de aula. In: ENCONTRO DE PESQUISA EM ENSINO DE FÍSICA, 8., 2002, Águas de Lindoia. Atas... São Paulo: Sociedade Brasileira de Física, 2002. Disponível em: <http:// www. sbf1. sbfisica. org. br/ eventos/ epef/ viii >. Acesso em: 27 maio 2012.

LEITE, Ligia; MUSTARO, Pollyana Notargiacomo; BARBETA, Vagner Bernal. Formação de professores a distância: uma iniciativa inovadora de avaliação de projetos. In: CONGRÉS ONLINE OBSERVATORI PER A LA CIBERSOCIETAT, 3., 2006, Barcelona. Comunicacions.... Barcelona: Observatori per a la Cibersocietat, 2006. Disponível em: $<$ http:// www. cibersociedad. net/ congres2006/ gts/ comunicacio. php ?id=95 \&llengua=ca>. Acesso em: 27 maio 2010.

LEITE, Selma. Histórico da UniRede. Portal da UniRede: Universidade Virtual Pública do Brasil. 2007. Disponível em: <http:// www. aunirede. org. br/ portal/ index. php? option= com_content $\&$ view $=$ article $\&$ id $=43 \&$ Itemid $=27>$. Acesso em: 05 fev.2012.

LÉVY, Pierre. As tecnologias da inteligência: o futuro do pensamento na era da informática. Tradução de Carlos Irineu da Costa. São Paulo: Ed.34, 1993.

Cibercultura. Tradução de Carlos Irineu da Costa. 2.ed. São Paulo: Ed.34, 2009.

LIMA, Ana Cristina Cristo Vizeu. Educação a distância e formação continuada em ciências: indicativos para configuração de cursos via internet. In: CONGRESSO INTERNACIONAL ABED DE EDUCAÇÃO A DISTÂNCIA, 15., 2009, Fortaleza. Trabalhos científicos... São Paulo: Associação Brasileira de Pesquisa em Educação em Ciências, 2009. Disponível em: $<$ http:// www. abed. org. br/ congresso2009>. Acesso em: 17 jul.2012.

LYRA, Augusto Tavares de. História do Rio Grande do Norte: 3.ed. Natal: Ed.UFRN, 2008.

LORENZONI, Ionice. Formação de professores no Timor Leste é bem avaliada. Portal de Notícias do Ministério da Educação. 17 mar.2006. Disponível em: <http:// portal. mec. gov. br/ index. php? option $=$ com $_{-}$content $\&$ view $=$ article $\& \mathrm{id}=5801 \&$ catid $=210>$. Acesso em: 05 fev.2012.

MAGALHÃES, António; STOER, Stephen R. A nova classe média e a reconfiguração do mandato endereçado ao sistema educativo. Educação, Sociedade \& Culturas, n.18, p.25-40, 2002. 
MAIA, Genilson Medeiros. A invasão holandesa no Rio Grande. História do Rio Grande do Norte na Web, Curso de História do Ceres, campus de Caicó da UFRN, 1998. Disponível em: <http:// www. cerescaico. ufrn. br/ rnnaweb/ historia/ colonia/ invasao. htm>. Acesso em: 30 nov. 2011.

MANZINI, Gabriela. Haddad critica ensino superior privado e defende fechamento de vagas. Folha.com. 25 mar.2008. Disponível em: <http:// www1. folha. uol. com. br/ folha/ educacao/ ult305u385692. shtml>. Acesso em: 12 fev 2012.

MARTINS, Guilherme Paiva de Carvalho. Tecnologias de informação e comunicação na educação: mudanças e inovações no ensino superior. 2009. 272 f. Tese (Doutorado em Sociologia). Instituto de Ciências Sociais da Universidade de Brasília, Brasília, 2009.

MASUDA, Masako Oya. O sistema de tutoria nos cursos do Centro de Educação Superior a Distância do Estado do Rio de Janeiro (Cederj). 2003. Disponível em: <http:// 200.156.15.182/ moodle/ file.php/ 1/ Biblioteca_Virtual/ O_ SISTEMA_ DE_ TUTORIA_ NOS_ CURSOS_DO_ CENTRO_ DE_ EDUCACAO_ SUPERIOR_ A D DISTANCIA_ DO_ESTADO_DO_RIO_DE_JANEIRO_CEDERJ_.doc>. Acesso em: 27 mar.2011.

MELEIRO, Alessandra; GIORDAN, Marcelo. Hipermídia no ensino de modelos atômicos. Química Nova na Escola, n.10, p.17-20, nov.1999.

MELO, Amanda Meincke; LOBATO, Cláudio Rocha. Computadores e sociedade: educação a distância. Santa Maria, RS: Universidade Federal de Santa Maria, 2000. Disponível em: $<$ http://www-usr. inf. ufsm. br/ cacau/ elc202/ amanda. html>. Acesso em: 30 jun.2010.

MINISTÉRIO DA EDUCAÇÃO. Programa Nacional de Tecnologia Educacional. Disponível em: <http:// portal. mec. gov. br/ index. php ?option=com_content \&view=article $\& \mathrm{id}=244$ \&Itemid=823>. Acesso em: 22 jun.2010.

Programa de Formação Inicial para Professores em Exercício no Ensino Fundamental e no Ensino Médio (Pró-Licenciatura). Anexo III. Propostas Conceituais e Metodológicas. 10 ago.2005. Disponível em: <http:// portal. mec. gov. br/ seb/ arquivos/ pdf/ proli_an3. pdf>. Acesso em: 05 fev.2012.

Secretaria de Educação a Distância. Programa de Formação de Professores em Exercício. Histórico. 2006. Disponível em: <http:// proformacao. proinfo. mec. gov. br/ historico. asp>. Acesso em: 05 fev.2012.

Fundo Nacional de Desenvolvimento da Educação. Conselho Deliberativo. Resolução CD/FNDE/no 34, de 9 de agosto de 2005. Estabelece os critérios e os procedimentos para a apresentação, seleção e execução de projetos de cursos de licenciatura para professores em exercício nas redes públicas nos anos/séries finais do ensino fundamental e/ou no ensino médio, na modalidade de educação a distância. Disponível em: <http:// www2. undime. org. br/ htdocs/ download. php? form= .pdf\& id=780>. Acesso em: 05 fev.2012.

Secretaria de Educação a Distância. Departamento de Política de EaD. Chamada Pública MEC/SEED no 01/2004: seleção pública de propostas para apoio financeiro à educação superior a distância. Disponível em: <http:// portal. mec. gov. br/ seed/ arquivos/ pdf/ chamadapublica1. pdf>. Acesso em: 10 fev.2012. 
Secretaria de Educação a Distância. Referenciais de Qualidade para Educação Superior a Distância, ago.2007. Disponível em: <http:// www. unirio. br/ cead/ pdf/ Referencias_Qualidade_EAD. pdf>. Acesso em: 12 fev.2012.

MOON, Bob. O papel das novas tecnologias da comunicação e da educação a distância para responder à crise global na oferta e formação de professores: uma análise da experiência de pesquisa e desenvolvimento. Educação \& Sociedade, Campinas, v.29, n.104, p.791-814, out. 2008.

MORAES, Reginaldo Carmello Corrêa de. Educação a distância e ensino superior: introdução didática a um tema polêmico. São Paulo: Senac São Paulo, 2010.

MOREIRA, Alcides do Nascimento. Percepção docente e discente do modelo pedagógico de EaD - mídia televisiva e ambiente virtual de aprendizagem: o caso da Unitins. 2009. 156 f. Dissertação (Mestrado em Educação). Faculdade de Educação da Universidade de Brasília, Brasília, 2009.

MORETZ-SOHN, Maria Cristina D'Almeida. A estruturação do ensino superior no Tocantins: caminhos e descaminhos da Unitins. Dissertação (Mestrado em Educação). 2002. 143 f. Faculdade de Educação da Universidade Federal de Goiás, Goiânia, 2002.

MOTA, Ronaldo; CHAVES FILHO, Hélio; CASSIANO, Webster Spiegel. Universidade Aberta do Brasil: democratização do acesso à educação superior pela rede pública de educação a distância. In: CHAVES FILHO, Hélio (Org.). Desafios da educação a distância na formação de professores. Brasília: Secretaria de Educação a Distância do Ministério da Educação, 2006.

MOTTA, Alexandre; ANGOTTI, José André Peres. Avaliação discente de um curso de tecnologia em Gestão Pública à luz da teoria da interação a distância. Revista Brasileira de Ensino de Ciência e Tecnologia, v.4, n.1, jan./abr.2011.

MUNDIM, Kleber Carlos. Ensino a distância no Brasil: problemas e desafios. In: CHAVES FILHO, Hélio (Org.). Desafios da educação a distância na formação de professores. Brasília: Secretaria de Educação a Distância do Ministério da Educação, 2006.

NASCIMENTO, Júnio Batista do. Tocantins: história e geografia. 6.ed. Goiânia: Bandeirante, 2009.

NEDER, Maria Lucia Cavalli. A formação do professor a distância: desafios e inovações na direção de um prática transformadora. Tese (Doutorado em Educação). 2004. $377 \mathrm{f}$. Universidade Federal de Santa Catarina, Florianópolis, 2004. Disponível em: <http:// www. tede. ufsc. br/ teses/ PEED0495. pdf>. Acesso em: 20 ago.2012.

PERERIA, Jodevaldo. Ciência e Tecnologia participa de lançamento do Processo seletivo UAB/Unitins. Secretaria da Ciência e Tecnologia. Governo do Estado do Tocantins. 2010. Disponível em: $<$ http:// www. tecnologia. to. gov. br/ noticia. php? noticia $=110>$. Acesso em: 17 maio 2011.

PERNAMBUCO, Marta Maria Castanho Almeida. Educação e escola como movimento: do ensino de ciências à transformação da escola pública. 1994. 156 f. Tese (Doutorado em Educação). Faculdade de Educação da Universidade de São Paulo, São Paulo, 1994. 
PINTO, Simone Andréa. A presença da ausência: a formação do pedagogo na modalidade a distância da Universidade do Tocantins. 2007. 233 f. Dissertação (Mestrado em Educação). Faculdade de Educação da Universidade de Brasília, Brasília, 2007.

PRETI, Oreste. Educação a distância e globalização: desafios e tendências. Revista Brasileira de Estudos Pedagógicos, Brasília, v.79, n.191, p.19-30, jan./abr.1998.

PRETTO, Nelson de Luca; PEREIRA, Isabel Cristina Auler. Ensino superior no Brasil: a implantação da Unitins e o uso da EaD como estratégia expansionista de uma universidade pública. Perspectiva, Florianópolis, v.26, n.2, p.663-691, jul./dez.2008.

RAMACCIOTTI, Angélica Santos. A prática de diálogo em PF na educação on-line, uma pesquisa bibliográfica digital: aproximações. 2010. 84 f. Dissertação (Mestrado em Educação: Currículo). Pontifícia Universidade Católica de São Paulo, São Paulo, 2010.

ROSSINI, Alessandro Marco. A educação e o mito do ensino a distância no Brasil. Millenium: revista do ISPV, Viseu, n.29, p.16-27, jun.2004.

SANTAROSA, Lucila M. Costi; PASSERINO, Liliana Maria; CARNEIRO, Mára Lúcia; GELLER, Marlise. Formação de professores a distância e em serviço através de ambientes digitais: a vivência do Proinesp. Revista Novas Tecnologias na Educação, Porto Alegre, v.3, n.2, nov.2005.

SAVIANI, Dermeval. Formação de professores no Brasil: dilemas e perspectivas. Poiesis Pedagógica, v.9, n.1, p.7-19, jan./jun.2011.

SCAFF, Elisângela Alves da Silva. Os organismos internacionais e as tendências para o trabalho do professor. Campo Grande: Ed. UFMS, 2000.

SCHEIBE, Leda. Formação de professores: dilemas da formação inicial a distância. Educere et Educare, Cascavel, v.1, n.2, p.199-212, 2006.

SCHLÜNZEN, Elisa Tomoe Moriya; SCHLÜNZEN Junior, Klaus; TERÇARIOL, Adriana Aparecida de Lima. Universidade Aberta do Brasil: democratização do acesso à educação superior pela rede pública de educação a distância. In: CHAVES FILHO, Hélio (Org.). Desafios da educação a distância na formação de professores. Brasília: Secretaria de Educação a Distância do Ministério da Educação, 2006.

SCHNEIDER, Magalis Bésser Dorneles. A formação de professores a distância: um estudo da Unisul Virtual. 2008. 137 f. Dissertação (Mestrado em Educação). Faculdade de Educação da Universidade de Brasília, Brasília, 2008.

SECRETÁRIO culpa formação superior. Tribuna do Norte. 2009. Disponível em: <http:// www. tribunadonorte. com. br/ print. php? not_id=125963>. Acesso em: 17 fev.2011.

SEGENREICH, Stella Cecília Duarte. ProUni e UAB como estratégias de EaD na expansão do ensino Superior. Pro-Posições, Campinas, v.20, n.2, p.205-222, maio/ago.2009.

SHULMAN, Lee S. Those who understand: knowledge growth in teaching. Educational Researcher, v.15, n.2, p.4-14, fev.1986. 
SILVA, Angela Noleto da. A formação por um fio: o tutor na EaD no estado do Tocantins. 2009. 150 f. Dissertação (Mestrado em Educação). Faculdade de Educação da Universidade Federal de Goiás, Goiânia, 2009.

SILVA Júnior, João dos Reis. Reformas do Estado e da educação e as políticas públicas para a formação de professores a distância: implicações políticas e teóricas. Revista Brasileira de Educação, n.24, p.78-94, set./dez.2003.

SILVA, Kátia Augusta Curado Pinheiro Cordeiro da. Professores com formação stricto sensu e o desenvolvimento da pesquisa na educação básica da rede pública de Goiânia: realidade, entraves e possibilidades. 2008. 292 f. Tese (Doutorado em Educação). Faculdade de Educação da Universidade Federal de Goiás, Goiânia, 2008.

SOUZA, Carlos Alberto; DE BASTOS, Fábio da Purificação; ANGOTTI, José André Peres. A mediação dos meios tecnológico-comunicativos. In: ENCONTRO IBEROAMERICANO DE COLETIVOS ESCOLARES E REDES DE PROFESSORES QUE FAZEM INVESTIGAÇÃO NA SUA ESCOLA, 4., 2005, Lajeado. Trabalhos... Lajeado: Unidade Integrada Vale do Taquari de Ensino Superior, 2005. Disponível em: <http:// ensino. univates. br/ 4iberoamericano/ trabalhos/ trabalho070.pdf>. Acesso em: 27 maio 2012.

SOUZA, Raquel Aparecida. Da Unitins à UFT: modelos e práticas gestoriais na educação superior do estado do Tocantins no limiar do século XXI. 2007. 178 f. Dissertação (Mestrado em Educação). Universidade Federal de Uberlândia, Uberlândia, 2007.

TAJRA, Sanmya Feitosa. Informática na educação. 8.ed. São Paulo: Érica, 2008.

THIOLLENT, Michel. Metodologia da pesquisa-ação. 16.ed. São Paulo: Cortez, 2008.

TOCANTINS (Estado). Lei $\mathrm{n}^{\circ}$ 872, de 13 de novembro de 1996. Determina o processo de extinção da autarquia em que se constitui a Universidade do Tocantins. Diário Oficial do Estado, Palmas, n. 562, 1996.

Lei $\mathrm{n}^{\mathrm{o}}$ 1160, de 19 de junho de 2000. Reestrutura a Fundação Universidade do Tocantins e adota outras providências. Diário Oficial do Estado, Palmas, n. 937, 2000.

Decreto $\mathrm{n}^{\mathrm{o}}$ 1672, de 27 de dezembro de 2002. Dispõe sobre a Fundação Universidade do Tocantins - Unitins. Diário Oficial do Estado, Palmas, n. 1347, 2002.

Secretaria de Estado da Cultura. Trajetória de luta pela criação do Tocantins. Disponível em: <http://cultura.to.gov.br/conteudo.php?id=94>. Acesso em: 07 fev.2012.

TOFFLER, Alvin. O choque do futuro. 7.ed. Rio de Janeiro: Record, 2001.

O big brother [entrevista]. Veja, n.1824, 15 out. 2003. Disponível em: <http:// veja. abril. com. br/ 151003/ entrevista. html>. Acesso em: 16 maio 2010.

TOSCHI, Mirza Seabra. O tempo e o espaço e a educação a distância. EccoS: revista científica, São Paulo, v.10, n.1, p. 23-38, jan./jun.2008.

UNESCO. Education Sector, Higher Education Division, Teacher Education Section. Teacher Education through Distance Learning: technology, curriculum, cost, evaluation. Paris: Unesco, 2001. 
UNIVERSIDADE ABERTA DO BRASIL. Página Inicial, Cursos, Bolsas. Coordenador de Tutoria. Disponível em: <http:// uab. capes. gov. br/ index. php? option= com_content\& view $=$ article $\&$ id $=48:$ coordenador-de-tutoria $\&$ catid $=11:$ conteudo $\&$ Itemid $=29>$. Acesso em: 14 jan.2012.

UNIVERSIDADE DE SÃO PAULO. Resolução da Reitoria $n^{\circ} 4871$, de 22 de outubro de 2001. Aprova o Código de Ética da USP. Diário Oficial do Estado de São Paulo, São Paulo, SP, 23 out. 2001.

UNIVERSIDADE FEDERAL DO RIO GRANDE DO NORTE. Projeto político-pedagógico do curso de licenciatura em Física a distância. Natal: Sedis-UFRN, 2004.

UNIVERSIDADE FEDERAL DO TOCANTINS. Educação a distância: apresentação. Disponível em: <http:// www. site. uft. edu. br/ ead/ ead/ apresentacao. html>. Acesso em: 19 fev.2011.

Projeto pedagógico do curso de Física. Palmas: CNTE, 2009.

História. Disponível em: < http:// www. site. uft. edu. br/ conheca-a-uft/ dados-uft/ historia. html>. Acesso em: 19 abr.2012.

VELLOSO, Rodrigo Paranhos (Ed.). Almanaque Abril 2007. 33.ed. São Paulo: Abril, 2006.

VIANNA, Deise Miranda. Uma disciplina integradora: instrumentação para o ensino. Perspectiva, n.17, p.59-66, 1992.

ZANETIC, João. Física também é cultura. 1989. 252 f. Tese (Doutorado em Educação). Faculdade de Educação da Universidade de São Paulo, São Paulo, 1989.

ZUIN, Antonio Alvaro Soares. Educação a distância ou educação distante? O programa Universidade Aberta do Brasil, o tutor e o professor virtual. Educação \& Sociedade, Campinas, v.27, n. 96, p. 935-954, 2006. 